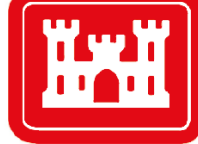

US Army Corps of Engineers ${ }_{\circledast}$

Engineer Research and

Development Center

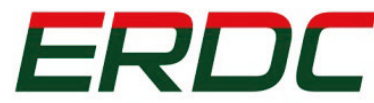

INNOVATIVE SOLUTIONS

for a safer, better world

Coastal Inlets Research Program

\title{
Merrimack Estuary and Newburyport Harbor Sediment Management Studies
}

Honghai Li, Mitchell Brown, Tanya Beck, Ashley Frey, June 2018 Julie Rosati, Mark Habel, John Winkelman, Edward O'Donnell, and Irene Watts

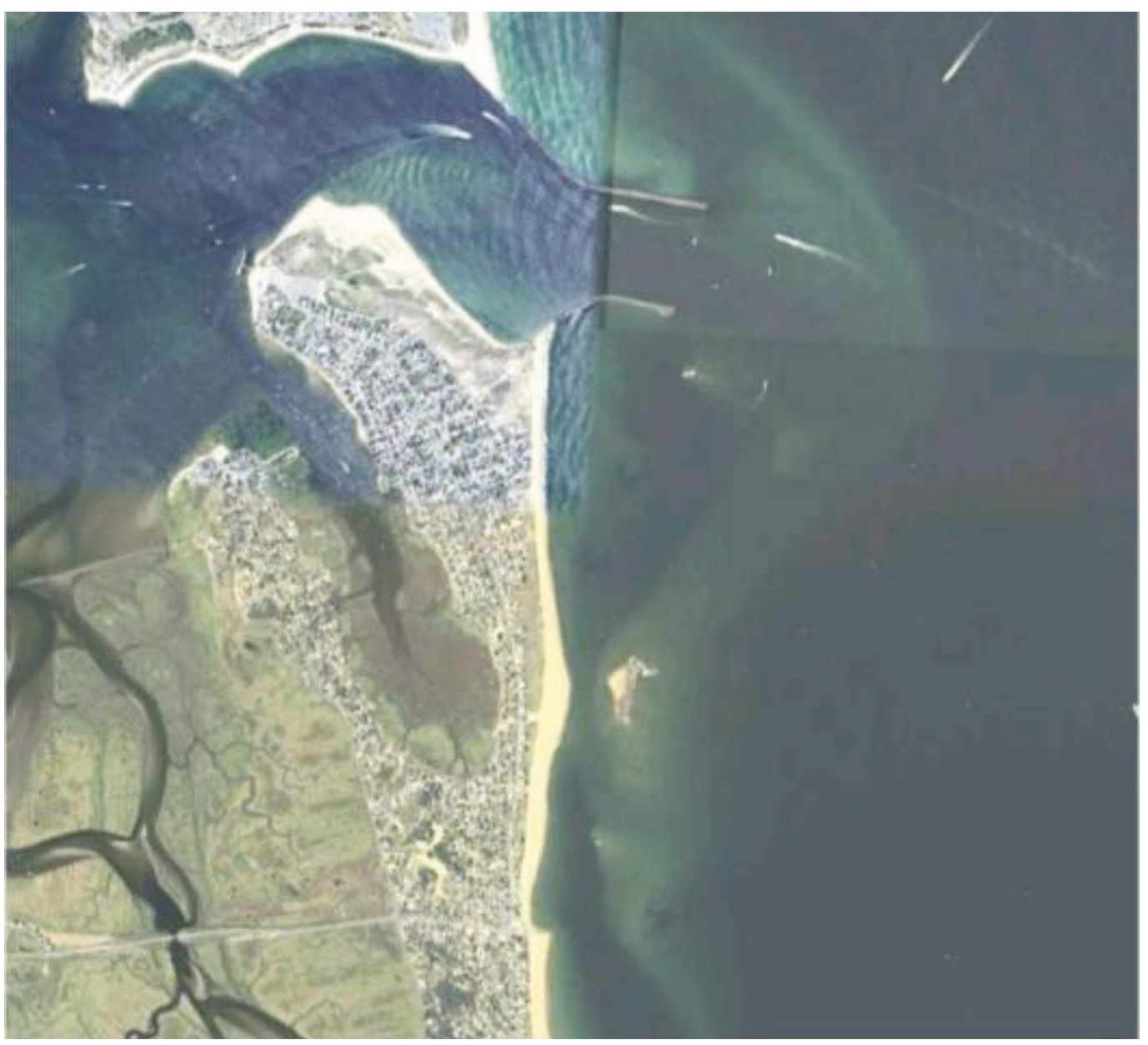


The U.S. Army Engineer Research and Development Center (ERDC) solves the nation's toughest engineering and environmental challenges. ERDC develops innovative solutions in civil and military engineering, geospatial sciences, water resources, and environmental sciences for the Army, the Department of Defense, civilian agencies, and our nation's public good. Find out more at www.erdc.usace.army.mil.

To search for other technical reports published by ERDC, visit the ERDC online library at http://acwc.sdp.sirsi.net/client/default. 


\section{Merrimack Estuary and Newburyport Harbor Sediment Management Studies}

Honghai Li, Mitchell Brown, Tanya Beck, Ashley Frey, and Julie Rosati

Coastal and Hydraulics Laboratory

U.S. Army Engineer Research and Development Center 3909 Halls Ferry Road

Vicksburg, MS 39180-6199

Mark Habel, John Winkelman, and Edward O'Donnell

New England District

U.S. Army Corps of Engineers

696 Virginia Road

Concord, MA 01742

Irene Watts

Florida Institute of Technology

150 West University Boulevard

Melbourne, FL 32901

Final report

Approved for public release; distribution is unlimited.

Prepared for U.S. Army Corps of Engineers, New England District 696 Virginia Road

Concord, MA 01742

Under Project 152124, "Merrimack Model Study" 


\section{Abstract}

This report documents a numerical modeling study investigating sediment transport and morphology change adjacent to Merrimack Inlet, Newburyport, and nearshore in the vicinity of Salisbury Beach and Plum Island, Massachusetts. Concerns at the site include beach erosion, shoreline retreat on Plum Island downdrift of and within the inlet, and reduced navigability of the inlet. The numerical modeling evaluation consists of two phases. The Phase I study was conducted with the damaged and partially rehabilitated South Jetty between 2012 and 2014, and the Phase II study was conducted with the fully rehabilitated South Jetty between 2015 and 2016.

Historical hydrodynamic and sediment data in the study area were assembled, and a field data collection program was carried out. The datasets were used to develop a coastal wave, hydrodynamic, and sediment transport model. Different alternatives were developed to evaluate sediment management strategy and structure modification, and the calculated bed sediment volume changes of each alternative were compared with the results under base (existing) condition. Alternative simulations demonstrated the Coastal Modeling System capability in evaluating beach erosion, structure performance, sediment transport, and morphology change in the inlet and estuarine system.

DISCLAIMER: The contents of this report are not to be used for advertising, publication, or promotional purposes. Citation of trade names does not constitute an official endorsement or approval of the use of such commercial products. All product names and trademarks cited are the property of their respective owners. The findings of this report are not to be construed as an official Department of the Army position unless so designated by other authorized documents. 


\section{Contents}

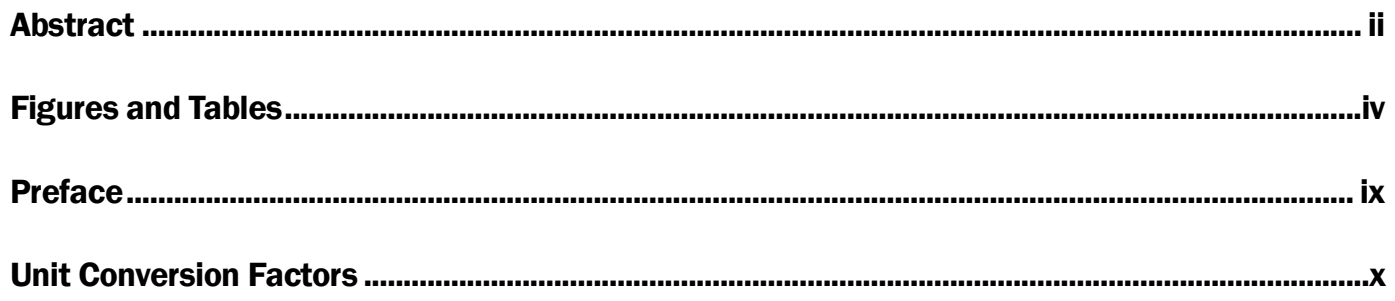

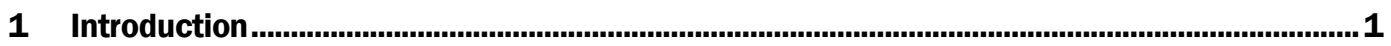

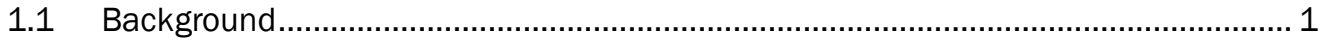

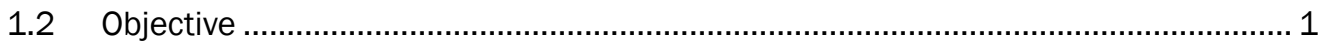

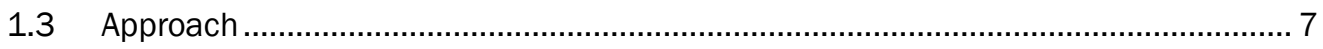

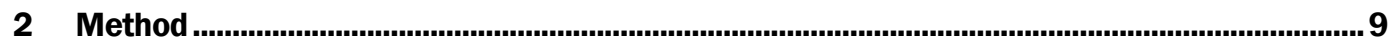

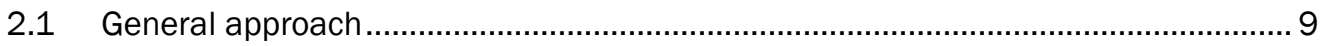

2.2 The Coastal Modeling System (CMS) ............................................................ 9

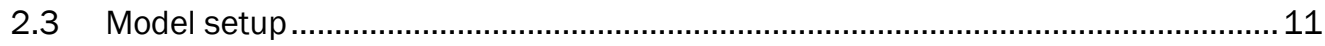

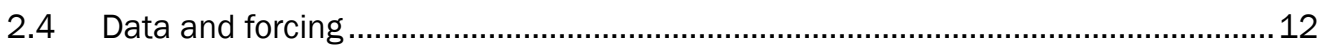

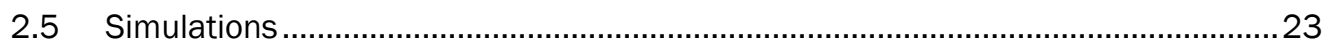

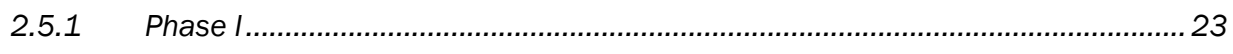

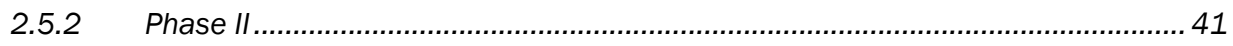

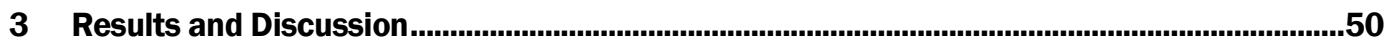

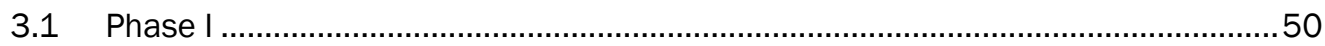

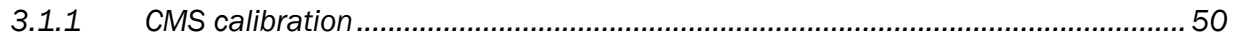

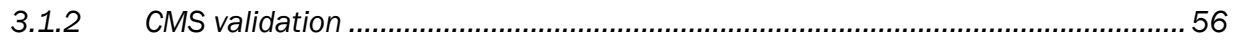

3.1.3 Representative winter and summer simulations ...............................................61

3.1.4 Partially rehabilitated South Jetty condition ....................................................... 62

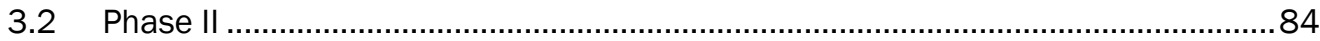

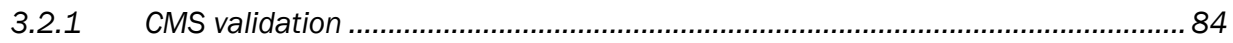

3.2.2 CMS simulations (December 2014-June 2015) ............................................... 89

3.2.3 Fully rehabilitated south Jetty condition .......................................................... 92

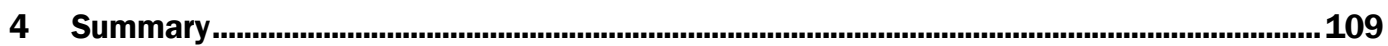

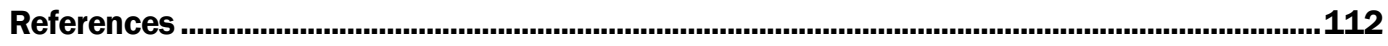

\section{Report Documentation Page}




\section{Figures and Tables}

\section{Figures}

Figure 1. Site location of Merrimack Inlet and Newburyport.

Figure 2. Shoreline position on Plum Island; inset shows shoreline change for selected reach from 1928 to 1994 (from Massachusetts office of Coastal Zone Management [CZM] Historic Shoreline Mapping)

Figure 3. Erosion on Salisbury Beach (From CZM Historic Shoreline Mapping)................................. 5

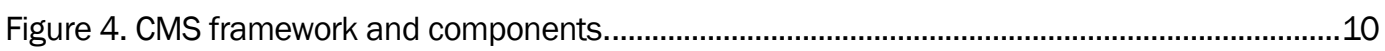

Figure 5. The CMS telescoping grid and bathymetry, and river inflow locations...............................12

Figure 6. Areal coverage of 2014 and 2015 lidar surveys. ............................................................13

Figure 7. NOAA tide gauge and buoy locations. The rectangle indicates the CMS domain. ..............14

Figure 8. Wave parameters at NDBC buoy \#44098, September 2012 ..........................................14

Figure 9. Wave parameters at NDBC buoy \#44098, January 2011...............................................15

Figure 10. Wave parameters at NDBC buoy \#44098, December 2014-June 2015. .......................15

Figure 11. Wind speeds and directions at NDBC buoy IOSN3, September 2012 and January 2011...................................................................................................................................

Figure 12. Wind speeds and directions at NDBC buoy IOSN3, December 2014 - June 2015.

Figure 13. WSE at NOAA tide gauge \#8423898, Fort Point, NH, September 2012 and January 2011.

Figure 14. WSE at NOAA tide gauge \#8423898, Fort Point, NH, December 2014 and June 2015.

Figure 15. River inflow at USGS gauge, Merrimack River, September 2012 and January 2011.

Figure 16. River inflow at USGS gauges, Merrimack River, Mill River, Parker River, and Ipswich River, December 2014 and June 2015. 19

Figure 17. Locations of water level gauge stations......................................................................20

Figure 18. Locations of deployed inlet and downdrift ADCP gauges. ................................................21

Figure 19. Sediment grab sampling locations in north Plum Island Sound. ......................................21

Figure 20. Sediment grab sampling locations and $D_{50}$ distributions in (a) Newburyport navigation channel and (b) at mouth of Merrimack River.

Figure 21. Partially rehabilitated South Jetty condition used for the representative winter month and the winter-spring period simulations of the 19 alternatives.

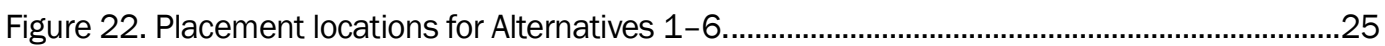

Figure 23. Alternative 1: Ebb delta mining and placement (in this figure, $\mathrm{CY}=$ cubic yards)............27

Figure 24. Alternative 2: Flood delta mining and placement (in this figure, $\mathrm{CY}=$ cubic yards)

Figure 25. Alternative 3: North Point (in this figure, $\mathrm{CY}=$ cubic yards)...........................................28

Figure 26. Alternative 4: Mine nearshore bars and placement locations (in this figure, $\mathrm{CY}=$ cubic yards).

Figure 27. Alternative 5: Multiple mining locations and placement (in this figure, $\mathrm{CY}=$ cubic yards). 
Figure 28. Alternative 6: Sedimentation basin located landward of the South Jetty

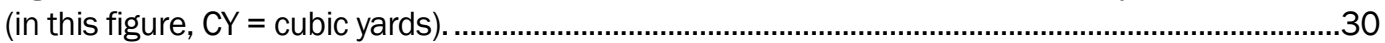

Figure 29. Alternative 7: Jetty removal. .....................................................................................31

Figure 30. Alternative 8: Lengthen jetties..................................................................................32

Figure 31. Alternative 9: Shorten jetties...................................................................................33

Figure 32. Alternative 10: Reoriented jetties................................................................................33

Figure 33. Alternative 11: Add dogleg extension to North Jetty.....................................................34

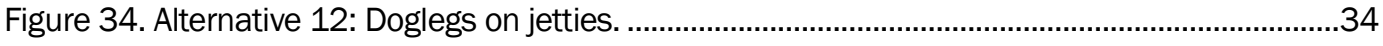

Figure 35. Alternative 13: Add spur inside North Jetty...............................................................35

Figure 36. Alternative 14: Add spur outside South Jetty..............................................................35

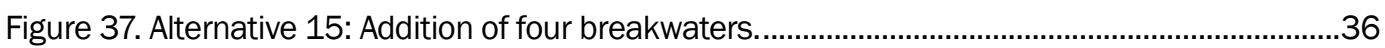

Figure 38. Alternative 2: 6-month flood delta mining and placement.............................................37

Figure 39. Alternative 3b: 6-month simulation of modified North Point mining and

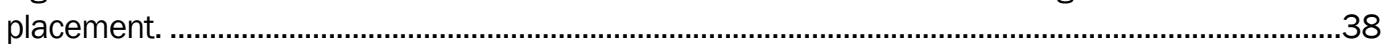

Figure 40. Alternative 6b: 6-month simulation of modified sedimentation basin (in this

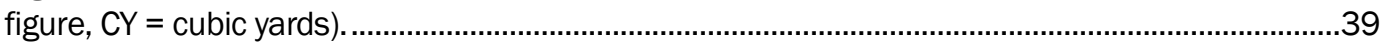

Figure 41. Alternative 9: 6-month simulation of shortened jetties...................................................39

Figure 42. Alternative 15b: 6-month simulation of eight total breakwaters.....................................40

Figure 43. Alternative 15c: 6-month simulation of eight total breakwaters and sedimentation basin mining and normal placement of material.

Figure 44. Observed morphology change between 15 December 2014 and 27 May 2015.

The coastal outline is the MSL contour. The warm color represents the deposition, and the cold color represents the erosion.

Figure 45. Alternative 1: Phase II 6-month simulation of flood delta mining and placement (in this figure, $\mathrm{CY}=$ cubic yards).

Figure 46. Phase II 6-month simulation of flood delta mining and placement, Alternative 2 (in this figure, $\mathrm{CY}=$ cubic yards).

Figure 47. Alternative 3c: Phase II 6-month simulation of modified North Point mining and

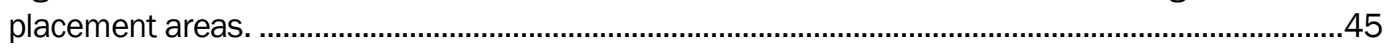

Figure 48. Alternative 9: Phase II 6-month simulation of shortened jetties. ......................................45

Figure 49. Alternative 15b: Phase II 6-month simulation of eight breakwaters.................................46

Figure 50. Alternative 15d: Phase II 6-month simulation of expanded breakwaters and ebb delta mining and placement.

Figure 51. Alternative 15e: Phase II 6-month simulation of shifted expanded breakwaters.

The image on the right depicts the shift of the eight breakwaters toward the south.........................48

Figure 52. Alternative 16: Ebb delta and north spit mining with modified placement areas (in this figure, $\mathrm{CY}=$ cubic yards).

Figure 53. Alternative 17: Ebb Delta mining with placement offshore of Plum Island to extend a natural bar formation (in this figure, $\mathrm{CY}=$ cubic yards). .....................................................49

Figure 54. Specifications of (a) non-erodible bed and (b) Manning's $n$. ...........................................51

Figure 55. Specifications of varying bed grain sizes $\left(D_{50}\right)$.............................................................52

Figure 56. Comparison of measured (blue line) and calculated (red line) water levels in Plum Island Sound. 
Figure 57. Simulated depth-averaged (a) flood and (b) ebb currents on 17 September 2012 at 14:00 and 20:00 GMT, respectively.

Figure 58. Simulated and measured currents in Merrimack Inlet.

Figure 59. Comparison of measured (blue line) and calculated (red line) water levels in Plum Island Sound. .57

Figure 60. Simulated and measured currents in Merrimack inlet for October 2012. .59

Figure 61. Measured (a) and calculated (b) Morphology change along the $15 \mathrm{ft}$ navigation channel.

Figure 62. Simulated mean current and sediment transport for September 2012 and January 2011 61

Figure 63. Simulated morphology changes for September 2012 and January 2011

Figure 64. Simulated morphology changes for the base condition (left panel) and Alternative 1 (right panel) results after the 1-month simulation. 63

Figure 65. Resulting morphology change due to Alternative 1.......................................................63

Figure 66. Simulated resulting morphology changes for Alternative 1..............................................64

Figure 67. Simulated resulting morphology changes for Alternative 2 . .............................................65

Figure 68. Simulated resulting morphology changes for Alternative 3...............................................66

Figure 69. Simulated resulting morphology changes for Alternative 4.............................................67

Figure 70. Simulated resulting morphology changes for Alternative 5..............................................68

Figure 71. Simulated resulting morphology changes for Alternative 6 . ............................................69

Figure 72. Simulated resulting morphology changes for Alternative 7...............................................70

Figure 73. Simulated resulting morphology changes for Alternative 8............................................. 71

Figure 74. Simulated resulting morphology changes for Alternative 9............................................72

Figure 75. Simulated resulting morphology changes for Alternative 10. .........................................73

Figure 76. Simulated resulting morphology changes for Alternative 11. ........................................ 74

Figure 77. Simulated resulting morphology changes for Alternative 12 .............................................75

Figure 78. Simulated resulting morphology changes for Alternative 13. ..........................................76

Figure 79. Simulated resulting morphology changes for Alternative 14. ..........................................77

Figure 80. Simulated resulting morphology changes for Alternative 15. ...........................................78

Figure 81. Simulated difference in morphology change between Alternative 2 and base condition for 6-month simulation.

Figure 82. Simulated difference in morphology change between Alternative $3 \mathrm{~b}$ and base condition for 6-month simulation..

Figure 83. Simulated difference in morphology change between Alternative $6 \mathrm{~b}$ and base condition for 6-month simulation...

Figure 84. Simulated difference in morphology change between Alternative 9 and base condition for 6-month simulation.

Figure 85. Simulated difference in morphology change between Alternative $15 \mathrm{~b}$ and base condition for 6-month simulation.

Figure 86. Simulated difference in morphology change between Alternative $15 \mathrm{c}$ and base condition for 6-month simulation.

Figure 87. Specifications of (a) non-erodible bed and (b) Manning's $n$. ............................................85

Figure 88. Specifications of bed grain sizes $\left(D_{50}\right)$. 
Figure 89. 14 sub-regions around Merrimack Inlet

Figure 90. Observed morphology change between 15 December 2014 and 27 May 2015.

The coastal outline is the MSL contour. The warm color represents the deposition, and

the cold color represents the erosion.

Figure 91. Simulated morphology change between 15 December 2014 and 15 June 2015. The coastal outline is the MSL contour. The black dashed outline spans the common extent of the 2014 and 2015 lidar surveys. The warm color represents the deposition, and the cold color represents the erosion.

Figure 92. Simulated mean current field (15 December 2014 and 15 June 2015)........................90

Figure 93. Simulated mean wave field (15 December 2014 and 15 June 2015). 90

Figure 94. Simulated mean sediment transport field (15 December 2014 and 15 June 2015).

Figure 95. Base Condition after 6-month simulation; morphology change (left) and final bathymetry (right)

Figure 96. Five polygon areas and bed volume changes within each area after 6-month simulation.

Figure 97. Initial bathymetry and final bathymetry of Alternative 1 and difference in morphology change between Alternative 1 and base condition.

Figure 98. Difference in morphology change and bed volume changes within each beach area between Alternative 1 and base condition after 6-month simulation.

Figure 99. Initial bathymetry and final bathymetry of Alternative 2 and difference in morphology change between Alternative 2 and base condition.

Figure 100. Difference in morphology change and bed volume changes within each beach area between Alternative 2 and base condition after 6-month simulation.

Figure 101. Initial bathymetry and final bathymetry of Alternative $3 c$ and difference in morphology change between Alternative $3 c$ and base condition.

Figure 102. Difference in morphology change and bed volume changes within each beach area between Alternative $3 c$ and base condition after 6 -month simulation.

Figure 103. Initial bathymetry and final bathymetry of Alternative 9 and difference in morphology change between Alternative 9 and base condition.

Figure 104. Difference in morphology change and bed volume changes within each beach area between Alternative 9 and base condition after 6-month simulation.

Figure 105. Initial bathymetry and final bathymetry of Alternative $15 \mathrm{~b}$ and difference in morphology change between Alternative 15b and base condition.

Figure 106. Difference in morphology change and bed volume changes within each beach area between Alternative $15 \mathrm{~b}$ and base condition after 6-month simulation.

Figure 107. Initial bathymetry and final bathymetry of Alternative $15 \mathrm{~d}$, and difference in morphology change between Alternative $15 \mathrm{~d}$ and base condition.

Figure 108. Difference in morphology change and bed volume changes within each beach area between Alternative $15 \mathrm{~d}$ and base condition after 6-month simulation.

Figure 109. Initial bathymetry and final bathymetry of Alternative 15e and difference in morphology change between Alternative 15e and base condition.

Figure 110. Difference in morphology change and bed volume changes within each beach area between Alternative $15 \mathrm{e}$ and base condition after 6-month simulation.

Figure 111. Initial bathymetry and final bathymetry of Alternative 16 and difference in morphology change between Alternative 16 and base condition. 
Figure 112. Difference in morphology change and bed volume changes within each beach area between Alternative 16 and base condition after 6-month simulation.

Figure 113. Initial bathymetry and final bathymetry of Alternative 17 and difference in morphology change between Alternative 17 and base condition.

Figure 114. Difference in morphology change and bed volume changes within each beach area between Alternative 17 and base condition after 6-month simulation.

\section{Tables}

Table 2-1. Summary of model simulations for the pre-rehabilitation (existing) condition. .23

Table 2-2. Sediment management alternatives and their descriptions.

Table 2-3. Structure modification alternatives and their descriptions. 31

Table 2-4. Summary of 6-month alternative simulations for Phase I.

Table 3-1. Water level goodness of fit statistics: September 2012 field data. .53

Table 3-2. Current goodness of fit statistics: September 2012 field data.

Table 3-3. Water level goodness of fit statistics: October 2012 field data.

Table 3-4. Current goodness of fit statistics: October 2012 field data.

Table 3-5. Observed and calculated bed volume changes in Merrimack Inlet from December 2014 to June 2015.

Table 3-6. Bed volume changes $\left(\times 1000 \mathrm{~m}^{3}\right)$ in five polygon areas under different alternatives.

Table 3-7. Difference in bed volume changes $\left(\times 1000 \mathrm{~m}^{3}\right)$ between alternative and base scenario in five polygon areas. 


\section{Preface}

This study was performed by the U.S. Army Engineer Research and Development Center, Coastal and Hydraulics Laboratory (ERDC-CHL), at the request of the U.S. Army Corps of Engineers (USACE), New England District under the "Merrimack Model Study" project.

The Coastal Inlets Research Program (CIRP) conducted this study with funding by the New England District. The CIRP is administered for Headquarters (HQ), USACE, by the ERDC-CHL, Vicksburg, MS, under the Navigation Program of HQUSACE. Mr. Jeff Mckee is HQUSACE Navigation Business Line Manager overseeing the CIRP. Mr. W. Jeff Lillycrop, CHL, is the ERDC Technical Director for Navigation. Dr. Julie Rosati, CHL, is the CIRP Program Manager. This work was conducted under the general administrative supervision of Ms. Tanya M. Beck and Ms. Ashley Frey, Chiefs of Coastal Engineering Branch and Coastal Processes Branch, respectively, and Dr. Jackie S. Pettway, Chief of the Navigation Division. Mr. Jeffrey R. Eckstein was the Deputy Director of CHL, and Mr. José E. Sànchez was the Director of CHL during this study period.

At the time of publication of this report, Mr. Jeffrey R. Eckstein was the Acting Director of CHL.

COL Bryan S. Green was Commander of ERDC, and Dr. David W. Pittman was the ERDC Director. 


\section{Unit Conversion Factors}

\begin{tabular}{|l|c|l|}
\hline Multiply & \multicolumn{1}{l|}{ By } & To Obtain \\
\hline acres & $4,046.873$ & square meters \\
\hline acre-feet & $1,233.5$ & cubic meters \\
\hline cubic feet & 0.02831685 & cubic meters \\
\hline cubic yards & 0.7645549 & cubic meters \\
\hline degrees (angle) & 0.01745329 & radians \\
\hline feet & 0.3048 & meters \\
\hline hectares & $1.0 \mathrm{E}+04$ & square meters \\
\hline inches & 0.0254 & meters \\
\hline knots & 0.5144444 & meters per second \\
\hline miles (nautical) & 1,852 & meters \\
\hline miles (US statute) & $1,609.347$ & meters \\
\hline miles per hour & 0.44704 & meters per second \\
\hline yards & 0.9144 & meters \\
\hline
\end{tabular}




\section{Introduction}

\subsection{Background}

The U.S. Army Corps of Engineers (USACE), New England District (NAE) requested that the U.S. Army Engineer Research and Development Center, Coastal and Hydraulics Laboratory (ERDC-CHL), perform a numerical modeling study of alternative sediment management and shore-protection strategies for Merrimack Inlet, Newburyport, and the adjacent beaches of Salisbury and Plum Island, Massachusetts. NAE maintains a federal navigation channel that begins oceanward of the inlet ebb shoal and ends at Newburyport Harbor, as well as two Storm Damage Risk Reduction Projects along adjacent beaches. Concerns for the study area include beach erosion, shoreline retreat on Plum Island downdrift of and within the inlet, and reduced navigability of the inlet.

With the setup of a coastal wave, hydrodynamic, and sediment transport model, model calibration and validation were conducted, and different alternatives were developed considering local sediment management of resources contained in the federal navigation project and shore protection strategies. Simulation results of each alternative are evaluated in its ability to reduce erosion of the adjacent beaches, maintain high performance of the jetties, and decrease shoaling in the inlet. The findings of the study are presented here to assist NAE and local stakeholders in development of a sediment management strategy that optimizes structural design and sediment bypassing strategies for Merrimack Inlet and the adjacent beaches.

\subsection{Objective}

Merrimack Estuary is an inlet system located in northern Massachusetts near the border with New Hampshire (Figure 1). Merrimack Inlet is adjacent to Salisbury Beach to its north and Plum Island to the south. Newburyport Harbor is located on the southern side of the Merrimack Estuary approximately 5.6 kilometers $(\mathrm{km})(3.5$ miles) from the mouth of the Merrimack River. The Merrimack Embayment, which includes Merrimack Inlet as well as the adjacent Salisbury Beach and Plum Island, is characterized as a mixed-energy and tide-dominated inlet (Hayes 1979; FitzGerald and Van Heteren 1999; Costas and FitzGerald 2011; Hein et al. 
2012). The mean tide range is approximately 2.6 meters $(\mathrm{m})$ ( 8.5 feet [ft]), and the average significant wave height is approximately $1 \mathrm{~m}(3.3 \mathrm{ft})$ (Abele 1977; Smith and FitzGerald 1994; Costas and FitzGerald 2011). Dominant waves generally approach from the northeast, which results in an alongshore net sediment transport direction from north to south (Hubbard 1975; Abele 1977; Costas and FitzGerald 2011). The tidal prism of Merrimack Embayment is approximately $3.0 \times 10^{7}$ cubic meters $\left(\mathrm{m}^{3}\right)$ (3.9 $\times 10^{7}$ cubic yard [cu yd]) (Hubbard 1975; FitzGerald et al. 2002).

Sediment samples show that the sand grain size in the channel of Merrimack Inlet ranges from coarse to very coarse; the fine to medium sand is only found along the sides of the channel. The inlet throat consists of very coarse sand while the sand in the ebb-tidal delta ranges from fine to very coarse with the coarsest sand located in a band from the jetty to offshore of Plum Island ${ }^{1}$ (FitzGerald et al. 2002; USGS 2016).

Figure 1. Site location of Merrimack Inlet and Newburyport.

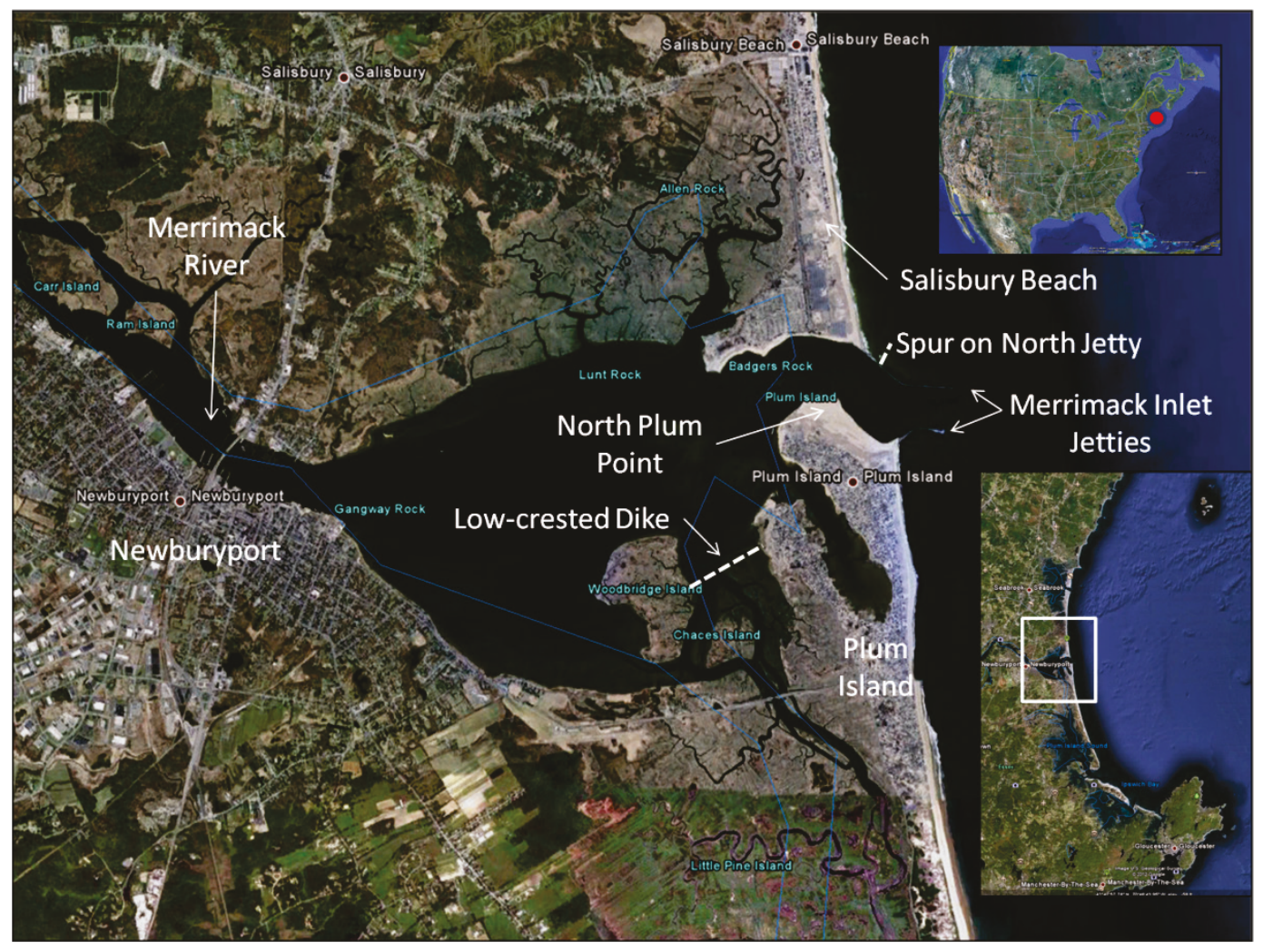

${ }^{1}$ Edward O'Donnell; NAE; personal communication; 16 August 2016. 
The formation of Plum Island and Salisbury Beach in front of the drowned river valley of the Merrimack River framed the Merrimack Inlet (Costas and FitzGerald 2011). Before jetties were used to stabilize the inlet, Merrimack Inlet would migrate to the south before breaching back to the north (Hartwell 1970; Hubbard 1975). Additionally, the shoreline configuration of Plum Island and Salisbury Beach changed over time. For example, in 1741, 1809, and 1826, a downdrift offset inlet occurred while 1776 experienced an updrift offset and a symmetric configuration occurred during 1851 (Hartwell 1970; Costas and FitzGerald 2011). The progradation of an adjacent inlet shore may cause the ebb-channel orientation to deflect towards the opposite shore, resulting in eventual erosion on the opposite side of the inlet (FitzGerald 1984). For example, sometime after 1826 , the ebb-channel began to deflect downdrift, which eroded the downdrift shore. Between 1826 and 1851, the deflected channel became inefficient, so a new channel was breached through the ebb-tidal delta. During this period, both shores experienced erosion caused by the channel orientation shift (FitzGerald 1993).

Downdrift of Merrimack Inlet, Plum Island is approximately $18 \mathrm{~km}$ (11 miles) long and is bordered by the Merrimack River, the Plum Island River, Plum Island Sound, the mouth of the Ipswich River, and the Atlantic Ocean. It has been a summer vacation destination since the late 1800 s, but it has more recently become a home to year-round residents. Vacation cottages and homes occupy the northern half of the island. The Parker River National Wildlife Refuge is located on the southern half of the island. Many of the beaches on Plum Island have experienced critical erosion, and at least one home was lost in 2008. A 2009 USACE NAE study stated that Plum

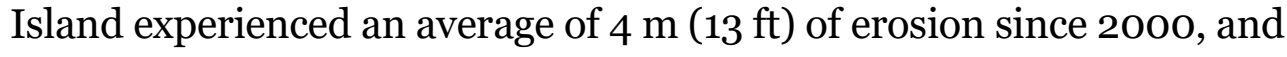
26 homes will be lost by 2019 if no action is taken (USACE 2009). In addition to the homes, a multi-million dollar water and sewer project and the only roadway connecting Plum Island to the mainland are also threatened. Figure 2 shows the shoreline position in 1928, 1952, 1978, and 1994. The inset in the figure shows a $0.8 \mathrm{~km}$ ( 0.5 mile) long stretch of shoreline located approximately $1.2 \mathrm{~km}$ (0.75 mile) to the south of Merrimack Inlet. The value at each transect represents the rate of yearly shoreline change in feet between 1928 and 1994. 
Figure 2. Shoreline position on Plum Island; inset shows shoreline change for selected reach from 1928 to 1994 (from Massachusetts office of Coastal Zone Management [CZM] Historic Shoreline Mapping).

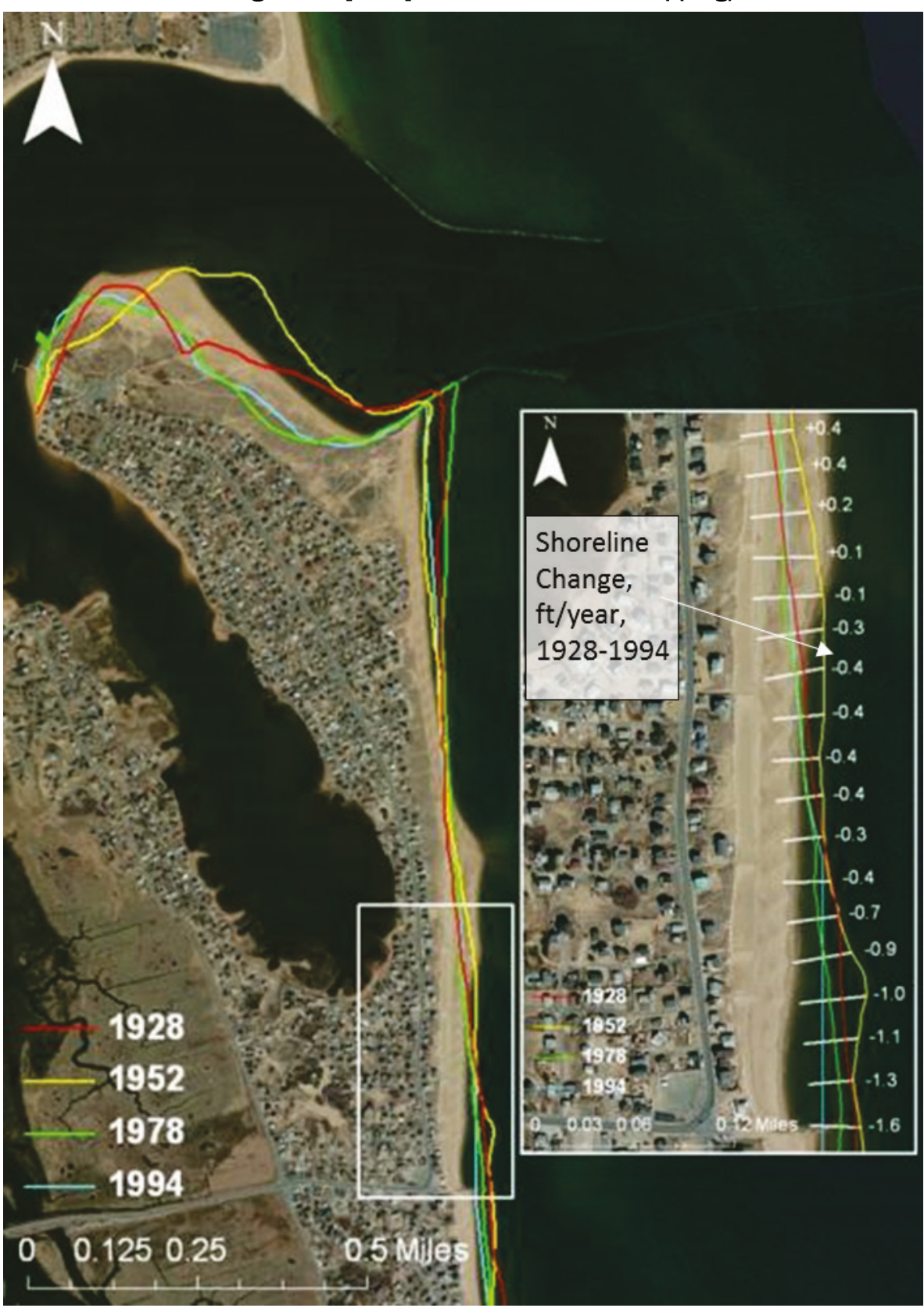

Salisbury Beach is located directly to the north of Merrimack Inlet and spans approximately $5.6 \mathrm{~km}$ (3.5 miles) north to the next municipality. Historically, Salisbury Beach was primarily a summer tourist resort. Over time, more families began to move to Salisbury Beach permanently, and now many residents live at Salisbury Beach year-round. Additionally, Salisbury Beach is more densely populated than Plum Island, where the lot size can be more than four times as large (Chiaramida 2008). There are 
approximately 250 parcels with oceanfront access. Although the beach grew from the 1950 s to 1970 s, it began experiencing erosion following the Blizzard of 1978. According to a map by the CZM, the southern end of the beach nearest to Merrimack Inlet has shown the most chronic erosion. Looking into the future, the present trend of erosion is expected to continue. Figure 3 shows the shoreline position during 1928, 1952, 1978, and 1994. The inset shows yearly shoreline change in feet between 1928 and 1994.

Figure 3. Erosion on Salisbury Beach (From CZM Historic Shoreline Mapping).

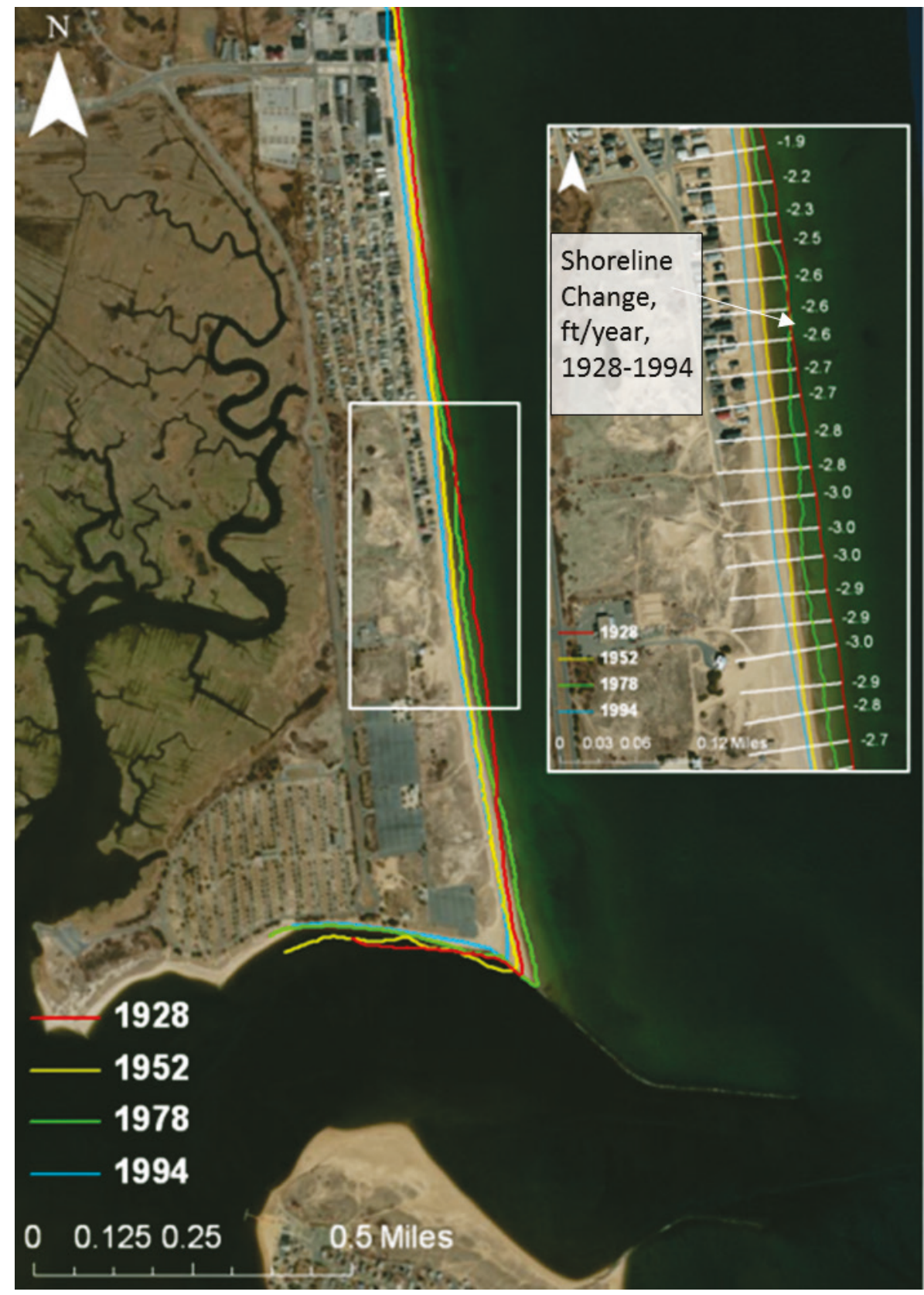


Merrimack Estuary is connected to Plum Island Sound to its south, which is a wetland estuary with small islands, tidal creeks, marshes, and ponds. The tidal amplitudes of Merrimack Estuary and Plum Island Sound are of the same order of magnitude, which are approximately $2.6 \mathrm{~m}(8.5 \mathrm{ft})$, and therefore Merrimack Estuary and Plum Island Sound are part of an integrated system (Vallino and Hopkinson 1998; Zhao et al. 2010).

While Newburyport Harbor does not import or export commercial tonnage, the harbor is popular for pleasure craft and fishing boats. The Newburyport Harbor Marina has a capacity of 65 deep-water slips and can accommodate boats up to $46 \mathrm{~m}$ ( $15 \mathrm{O} \mathrm{ft}$ ) in length. In addition to Newburyport Harbor, there is a U.S. Coast Guard Station located along the bank of the Merrimack River in Newburyport. The original station was built near the mouth of the Merrimack River in 1882, and due to beach erosion the station was moved to a new location in Newburyport in the early 1970s. Vessel traffic, whether by the Coast Guard or private boat, needs to navigate through the inlet safely. If the jetties degrade significantly below project specifications, abnormal currents and additional shoaling can occur, which would make navigating the channel more dangerous than under project conditions.

The project authorization for the improvement of Newburyport Harbor was enacted in 1880 (USACE 1965) and included dual riprap jetties and a low-crested timber dike to partially close the Plum Island Basin (see Figure 1). The purposes of the jetties were to create a permanent channel and protect vessels from storms while the dike was necessary to prevent a new channel forming across Plum Island (USACE 1965). Construction on the North Jetty began in 1881 and was completed to project dimensions in 1914 (USACE 1917). The South Jetty construction took place from 1883 to 1905. With the exception of a $9.1 \mathrm{~m}$ (30 ft) long section of the outer end, the South Jetty was completed to project specifications. Dredging of the entrance channel was authorized in 1910. The first dredging of the entrance channel occurred in 1937-1938 and approximately $256,125 \mathrm{~m}^{3}$ (335,000 cu yd) was dredged to establish a channel alignment between the jetties and the outer bar (USACE 1965). Dredging within Newburyport Harbor was authorized in 1945 and has taken place in the harbor and in the channel at irregular intervals since authorization. In 1952, a spur was constructed perpendicular from the north side of the North Jetty to slow erosion near the North Jetty (USACE 1965) Figure 1). 
The jetties at Merrimack Inlet require maintenance to repair damages from winter storms and hurricanes. The first maintenance work took place in 1910, and 540 tons of new stone were added (USACE 1965). Between 1900 and 1938 , maintenance work at the jetties was required 14 times. To lessen erosion on Plum Island, the South Jetty has been repaired to reach its designed height $(\sim 4.8 \mathrm{~m}(15.75 \mathrm{ft})$ above the mean sea level [MSL]) since 2014 .

\subsection{Approach}

This study was conducted over two phases to address initial alternative sediment management scenarios (Phase I) and modified alternative scenarios based on input from NAE (Phase II). Phase I was carried out between 2012 and 2014, during which the damaged inlet jetties were rehabilitated and restored to the designed jetty height through placement of additional jetty stone. The Coastal Modeling System (CMS), an integrated wave, circulation, and sediment transport model developed specifically for applications at coastal inlets, navigation channels, ports, and harbors, was configured for this inlet estuarine system and was calibrated and validated against water surface elevation (WSE) and current data collected in September-October 2012. The validation also includes a comparison between calculated sediment volume change and NAE-provided dredging records in the navigation channel. The calibration and validation were conducted under the pre-rehabilitated jetty condition, identified here as present day jetty condition.

Nineteen different alternatives were specified for the rehabilitated jetty conditions. Out of 19 alternatives, 15 are original and unique alternatives addressing different jetty configurations, additional structures, and mining and placement scenarios. Four of the alternatives are the modifications of some of the 15 original alternatives. The 15 original alternatives were evaluated using wave and hydrodynamic forcing conditions over 1 representative winter month. For longer-term evaluation, a 6-month simulation was run for the two selected original alternatives and all four of the modified alternatives.

NAE collected lidar survey data in December 2014 and May 2015 in the vicinity of Merrimack Estuary, Massachusetts. Significant shoreline change was identified north of Plum Island within the Merrimack Inlet during this time period. To further understand sediment transport pattern in Merrimack Inlet and the nearshore of Salisbury Beach and Plum Island, the 
Phase II study was initiated in 2015, in which the new lidar datasets were used to update the bathymetry in the existing CMS setup. Corresponding to the lidar data collection period, a 6-month simulation from 15 December 2014 to 15 June 2015 was set up. The CMS validation was performed by comparing the calculated and lidar-observed morphology and sediment volume changes around the inlet over this 6-month period. Based on the Phase I analysis, nine alternatives were selected and evaluated using this updated model configuration and wave and hydrodynamic forcing. Out of the nine alternatives, four are original alternatives specified in the Phase I study, three are modified alternatives based on the Phase 1 Study, and two are newly added modified alternatives.

This report is organized in four chapters. Chapter 1 presents the purpose of the study and a description and history of the site. Chapter 2 describes the general approach of the study, the CMS, and the configurations for different modeling alternatives. The results of the numerical modeling simulations of Phases I and II are presented in Chapter 3 with discussion on the comparison among different scenarios. Chapter 4 provides a summary of the study. 


\section{Method}

\subsection{General approach}

In the Merrimack Estuary and Newburyport Harbor study area, jetty degradation and severe beach erosion have become critical issues for the USACE. As a component of an ongoing Section 204 (beneficial reuse of dredged material) study, numerical modeling is applied to the study area to assist NAE in its analysis of shoaling within the inlet and sediment transport throughout the estuarine and nearshore area to find solutions for the improvement of channel navigability, jetty performance, and reduction of beach erosion.

The modeling study includes the development of a coastal wave, hydrodynamic, and sediment transport model for the region, model calibration and validation to field data, and the development and evaluation of alternatives.

\subsection{The Coastal Modeling System (CMS)}

The CMS was developed as an applied tool to assess Operations and Maintenance (O\&M) activities at coastal inlets, navigation channels, harbors, ports, estuaries, bays, coastal structures, and adjacent beaches by the Coastal Inlets Research Program (CIRP) at the ERDC. The CMS consists of two integrated numerical models that simulate waves, circulation, sediment transport, and morphology change: a hydrodynamic model, CMS-Flow (Buttolph et al. 2006; Wu et al. 2010, 2011; Sanchez et al. 2011a; Sanchez et al. 2011b), and a wave model, CMS-Wave (Lin et al. 2008, 2011). The CMS-Flow model also includes the calculations of sediment transport and morphology change. The framework and components of the CMS are shown in Figure 4. 
Figure 4. CMS framework and components.

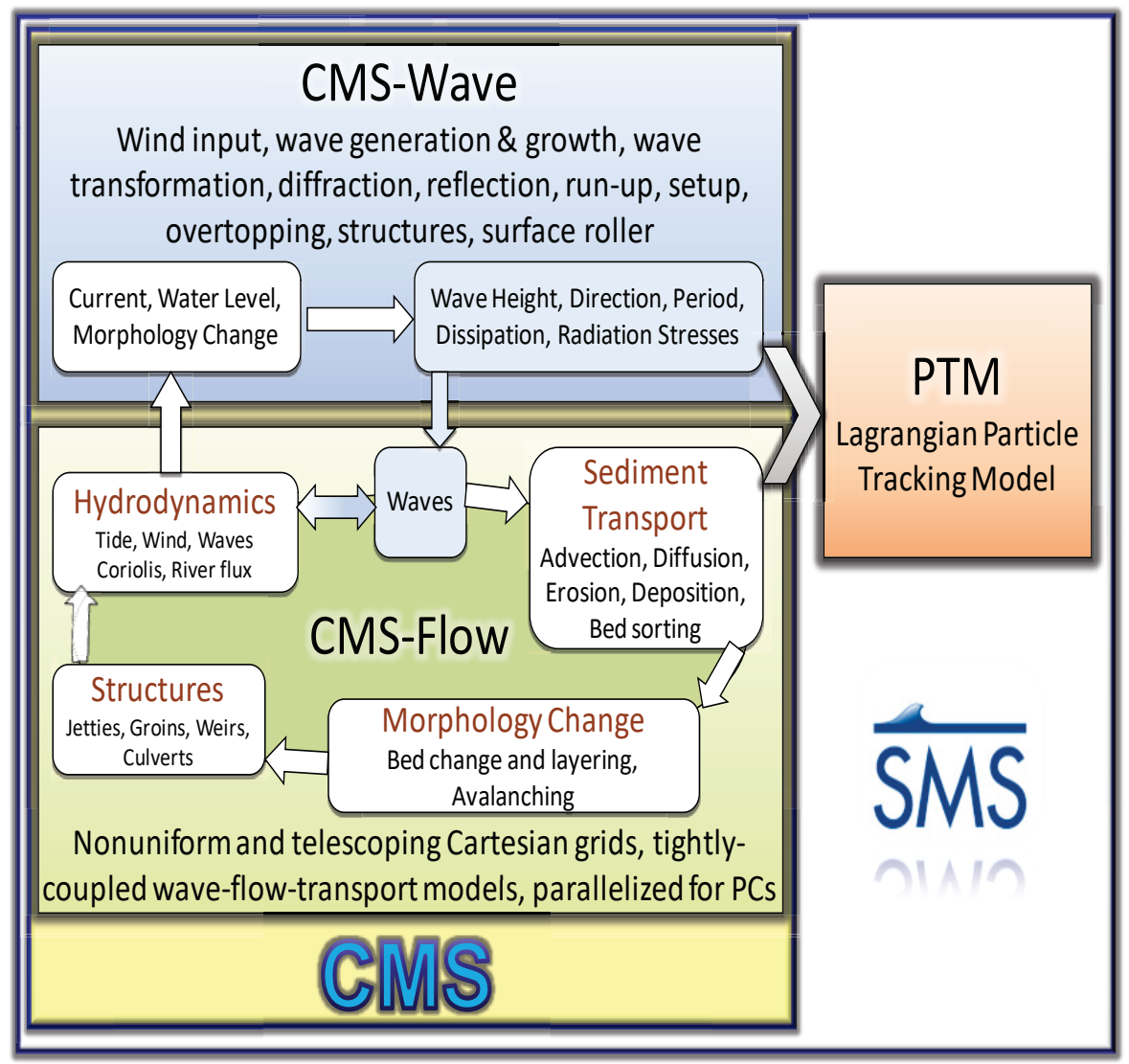

CMS-Flow is a two-dimensional, depth-averaged hydrodynamic model which calculates WSE and current, sediment transport and morphology change, and salinity transport. CMS-Flow can be driven by WSE (tide), wind, wave, and riverine inflow forcing. Physical processes in CMS-Flow include advection, diffusion, wave-current interaction, the Coriolis effect, and the influence of coastal structures (Buttolph et al. 2006; Wu et al. 2010, 2011; Sanchez et al. 2011a; Sanchez et al. 2011b). There are three sediment transport models available in CMS-Flow: a sediment mass balance model, an equilibrium advection-diffusion model, and a nonequilibrium advection-diffusion model. All governing equations of wave, flow and sediment transport models are solved using the finite volume method on a non-uniform Cartesian grid.

CMS-Wave is a two-dimensional (2D) spectral wave transformation model and solves the steady-state wave-action balance equation on a non-uniform Cartesian grid (Lin et al. 2008, 2011). It is formulated from a parabolic approximation equation (Mase et al. 2005) with energy dissipation and diffraction terms. CMS-Wave is a full-plane model with primary waves 
propagating from open boundaries toward inside domain. The model is designed to simulate wave processes that are significant in coastal inlets, in the nearshore zone, in the vicinity of jetties and breakwaters, and in ports and harbors. These processes include wave shoaling, refraction, diffraction, reflection, wave breaking and dissipation, wave-structure and wave-current interactions, and wave generation and growth mechanisms. Additional model features include the grid nesting capability, variable rectangle cells, wave run-up on beach face, wave transmission through structures, wave overtopping, and storm wave generation.

Over the past 10 years, the CMS has been applied to a number of U.S. and international study locations for the evaluation of inlet and coastal structure performance and rehabilitation and the design of sand management strategies such as ebb/flood shoal mining, channel reorientation, beach nourishment, and location of dredge material placement sites (Li et al. 2009; Beck and Kraus 2010; Demirbilek et al. 2010; Reed and Lin 2011; Lambert et al. 2013; Lin et al. 2013; Wang et al. 2013; Lu et al. 2014). An indepth verification and validation study of the CMS was also conducted independently and as an integrated system for hydrodynamics, waves, and sediment transport and morphology change for laboratory experiments and coastal applications (Demirbilek and Rosati 2011).

Considering all the features of the CMS described above and its capability to calculate for time periods associated with engineering activities and dredging cycles with a low computational cost, the CMS was used in this study to calculate physical processes in the vicinity of inlets, beaches, and navigation structures. However, as a coastal hydrodynamic, wave, and sediment transport model, the CMS was not developed to simulate physical processes over land, such as dune evolution and coastal bluff erosion, and was not appropriate to use for the prediction of beach process and shoreline change.

\subsection{Model setup}

A telescoping grid was developed for this coastal inlet and estuarine system. The CMS grid domain consists of 73,000 ocean cells, which covers the entire Plum Island Sound and the open ocean region. It extends approximately $20 \mathrm{~km}$ (12.4 mile) alongshore and 3-7 km (1.9-4.3 mile) offshore. The water depth ranges from 1 to $2 \mathrm{~m}$ (3.3 to $6.6 \mathrm{ft}$ ) above the MSL at tidal marsh areas in the Plum Island Sound to $13 \mathrm{~m}(42.7 \mathrm{ft})$ at the inlet navigation channel, and further increases to $40 \mathrm{~m}(131.2 \mathrm{ft})$ in the offshore boundary of the CMS domain. The telescoping grid system 
utilized by the CMS permits much finer local grid resolution to well resolve hydrodynamic and sediment features in areas of high interest. For this study, the finer cell sizes vary from 6 to $12 \mathrm{~m}$ (19.7 to $39.4 \mathrm{ft}$ ) around the Newburyport Inlet and the creeks and narrow channels linking the north and south Sound to $400 \mathrm{~m}$ (1312.4 ft) in the open ocean (Figure 5).

Figure 5. The CMS telescoping grid and bathymetry, and river inflow locations.

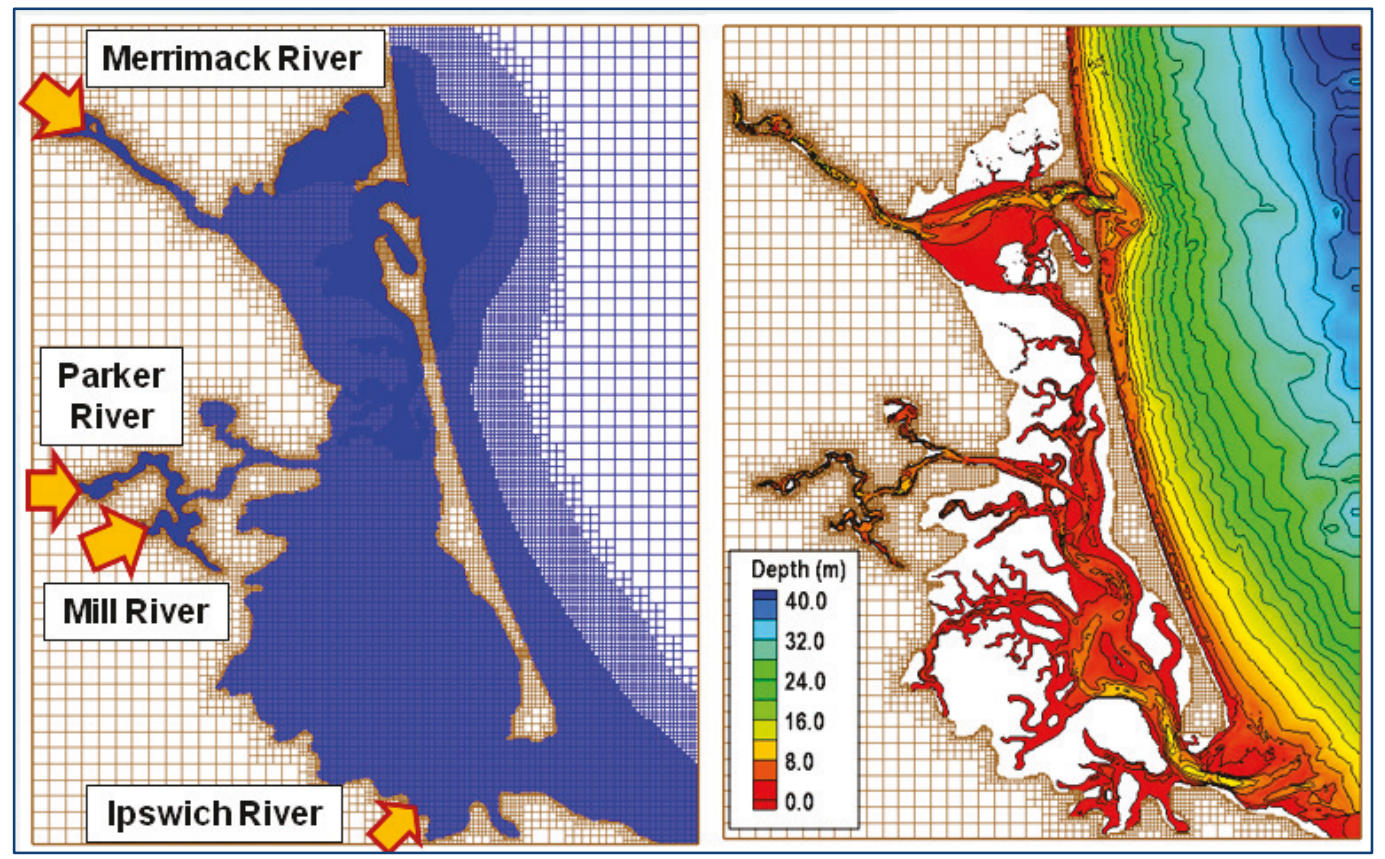

\subsection{Data and forcing}

The offshore bathymetric data were obtained from the GEOphysical DAta System database (NGDC 2009). The USACE, New England District ${ }^{1}$ provided before- and after-dredge surveys and topographic data around the Merrimack Inlet and the federal navigation channel and the Plum Island backbarrier estuary. The Long Term Ecological Research Network (National Science Foundation Grant 1238212) conducted kinematic bathymetry surveys in the small creeks and tidal marsh areas (Vallino and Hopkinson 1998). Historical high-resolution lidar surveys produced by the USACE and the National Oceanic and Atmospheric Administration (NOAA) cover Plum Island Sound and the nearshore areas. The latest lidar survey data were collected by the USACE in the vicinity of Merrimack Inlet in December 2014 and May 2015. Figure 6 shows the areal coverage of these two datasets.

1 William Walker; NAE; personal communication; 26 December 2013. 
Figure 6. Areal coverage of 2014 and 2015 lidar surveys.

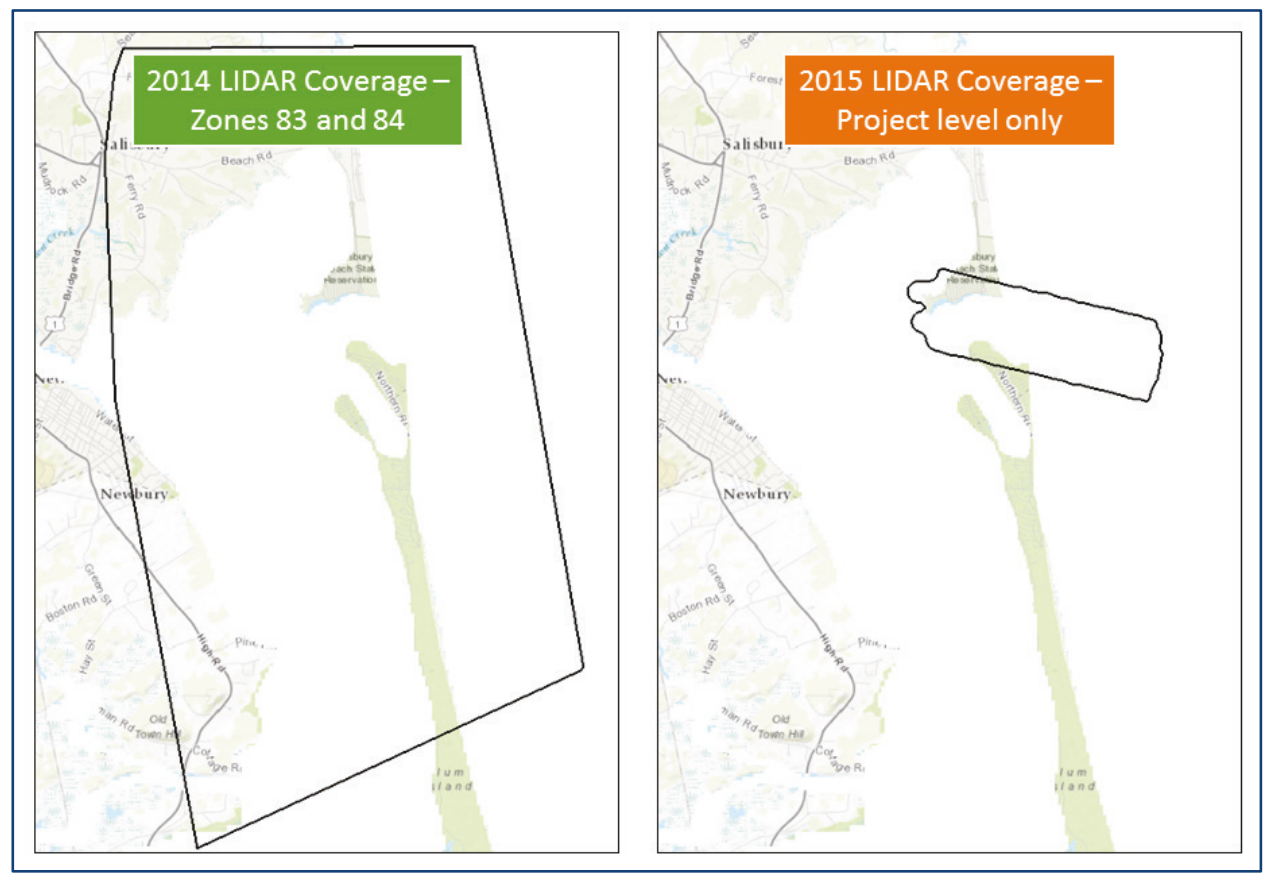

In the following forcing descriptions, 2011 and 2012 data were processed and used for the Phase I study, and 2014 and 2015 data were processed and used for the Phase II study.

Wave data were available from the National Data Buoy Center (NDBC) (www.ndbc.noaa.gov). The NDBC buoy \#44098 is located approximately $50 \mathrm{~km}$ (31 mile) offshore of the CMS open boundary (Figure 7). Directional wave spectra were retrieved for CMS simulations in a 2-hour interval and transformed to the model seaward boundary. The two monthly wave parameters are shown in Figure 8 and Figure 9, respectively, and the wave parameters between December 2014 and June 2015 are shown in Figure 10. The data analysis indicates that the predominant waves are from the east to southeast (90-180 deg azimuth) in low-energy months (September 2012, late spring, and early summer) and the northwest (270-360 deg azimuth) to northeast (o-90 deg azimuth) directions during high-energy months (winter and early spring). Large waves occur during the winter with extreme wave heights between 4 and $8 \mathrm{~m}$ (13.1 and $26.2 \mathrm{ft})$. The late spring-summerfall wave height is small, usually less than $2 \mathrm{~m}(6.6 \mathrm{ft})$. 
Figure 7. NOAA tide gauge and buoy locations. The rectangle indicates the CMS domain.

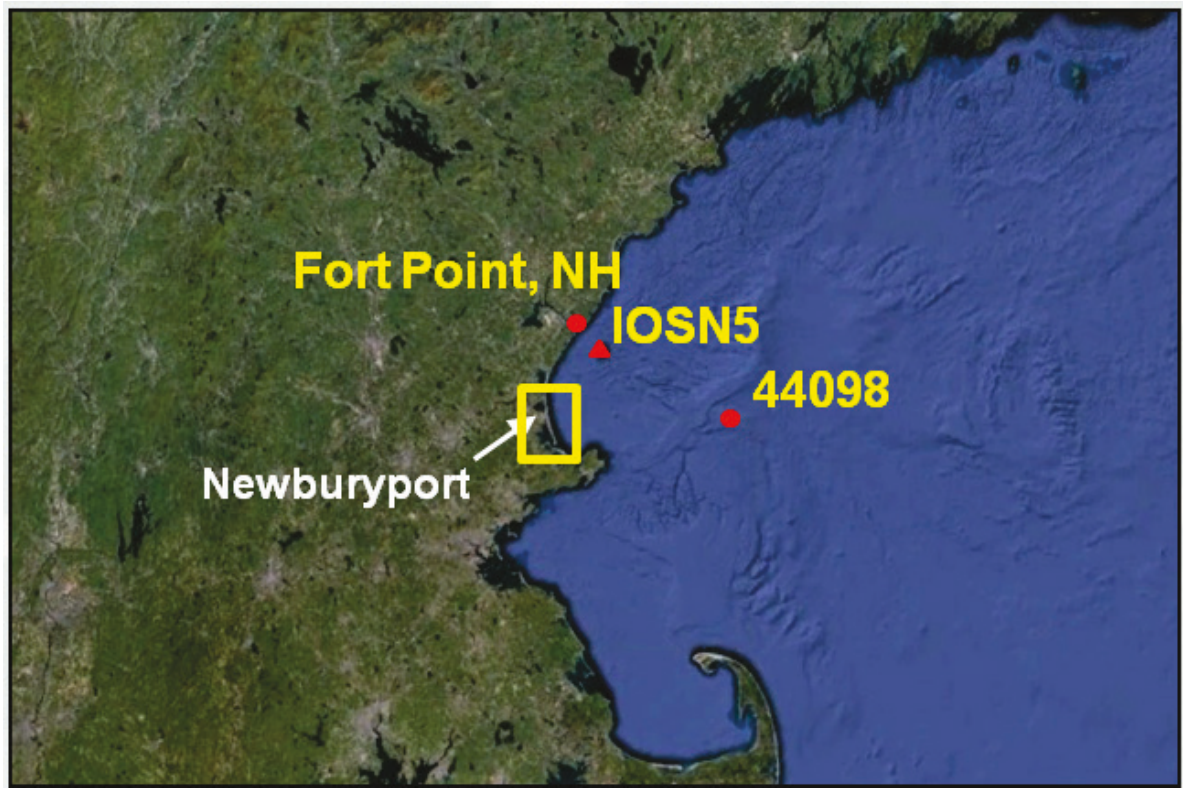

Figure 8. Wave parameters at NDBC buoy \#44098, September 2012.

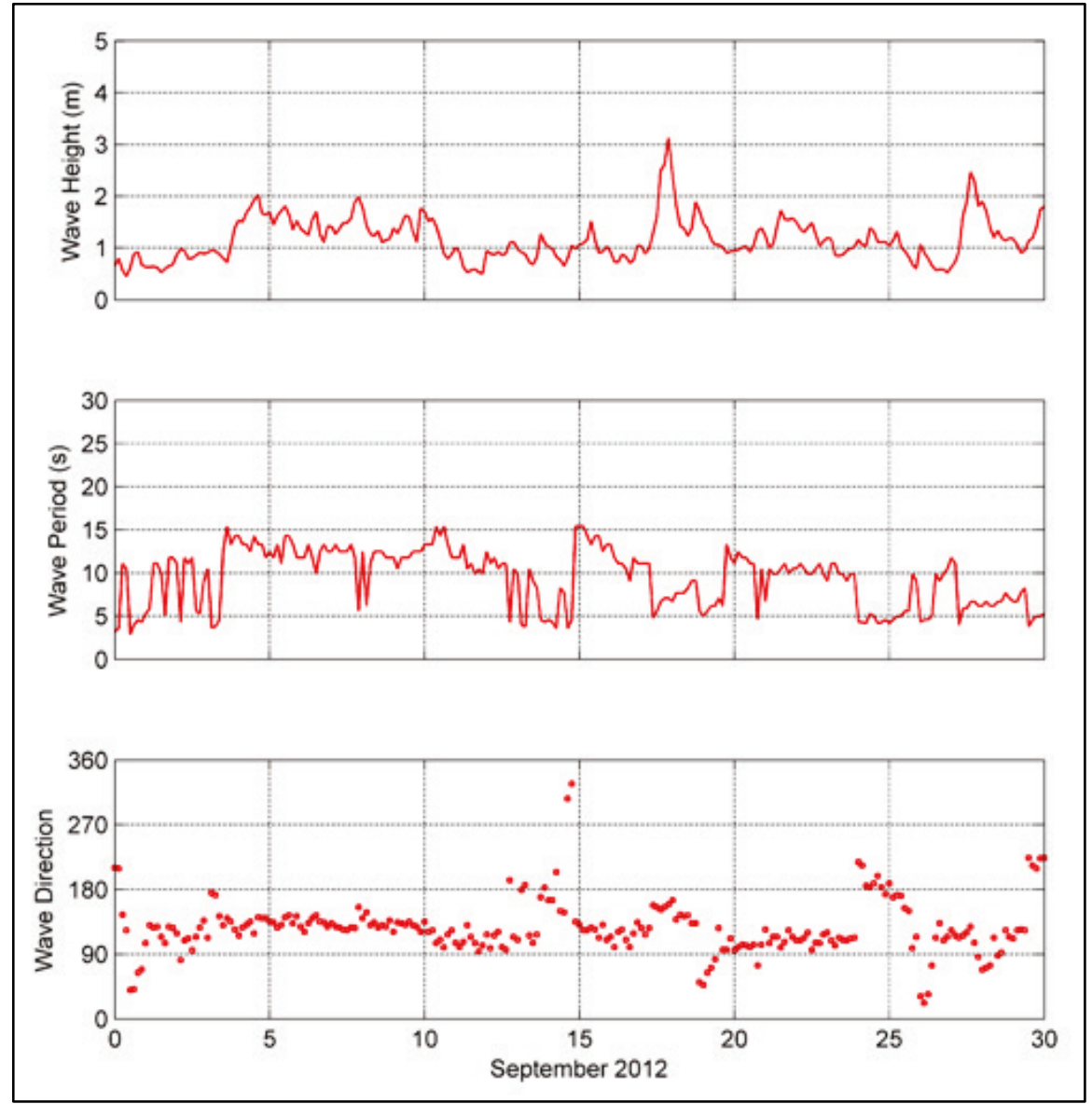


Figure 9. Wave parameters at NDBC buoy \#44098, January 2011.
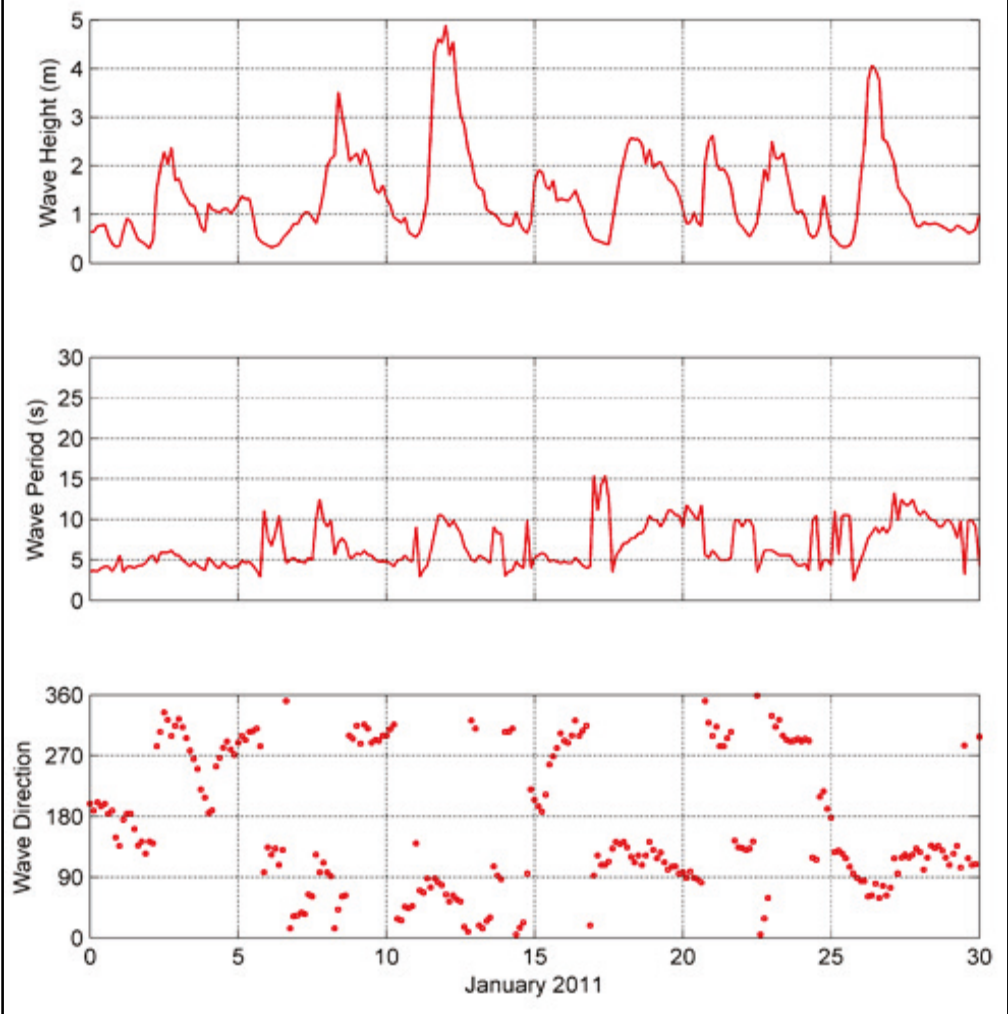

Figure 10. Wave parameters at NDBC buoy \#44098, December 2014-June 2015.
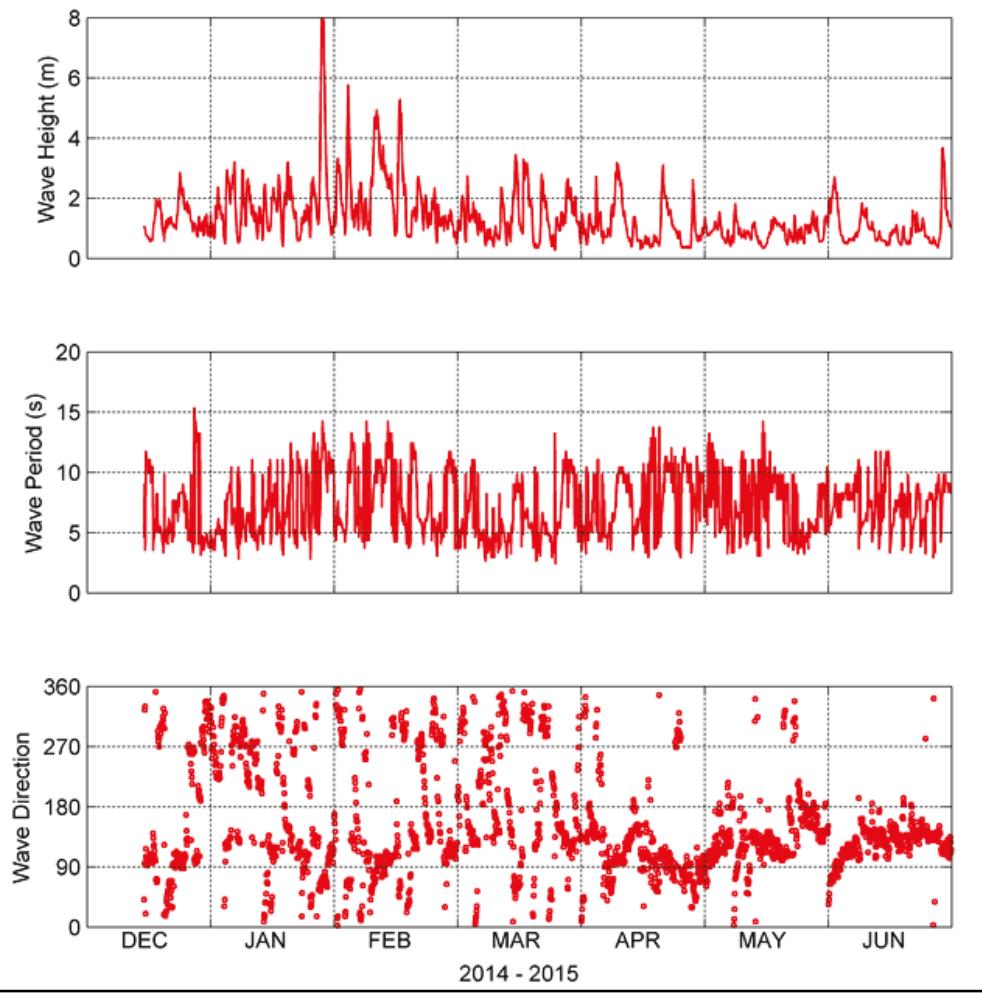
Wind observations were provided by another NDBC buoy IOSN3

(Figure 7), which is located approximately $17 \mathrm{~km}$ (10.6 miles) northeast of the CMS domain. Figure 11 and Figure 12 show wind speeds and directions observed in September 2012 and January 2011, and between December 2014 and June 2015, respectively. At this offshore buoy location, dominant winds are south-southwesterly during the late spring and summer-fall and west-northwesterly during the winter. The late spring and summer-fall months are relatively calm, and the frequency of storm occurrences starts to increase in October, and it decreases in April. The maximum and minimum monthly mean wind speeds are between 9.0-10.0 meters per second $(\mathrm{m} / \mathrm{s})(29.5-32.8 \mathrm{ft} / \mathrm{s})$ and approximately $6.0 \mathrm{~m} / \mathrm{s}(19.7 \mathrm{ft} / \mathrm{s})$ in winter and summer, respectively, and the September 2012 and January 2011 monthly mean wind speeds are $6.3 \mathrm{~m} / \mathrm{s}(20.7 \mathrm{ft} / \mathrm{s})$ and $8.0 \mathrm{~m} / \mathrm{s}$ $(26.2 \mathrm{ft} / \mathrm{s})$, respectively.

Figure 11. Wind speeds and directions at NDBC buoy IOSN3, September 2012 and January 2011.

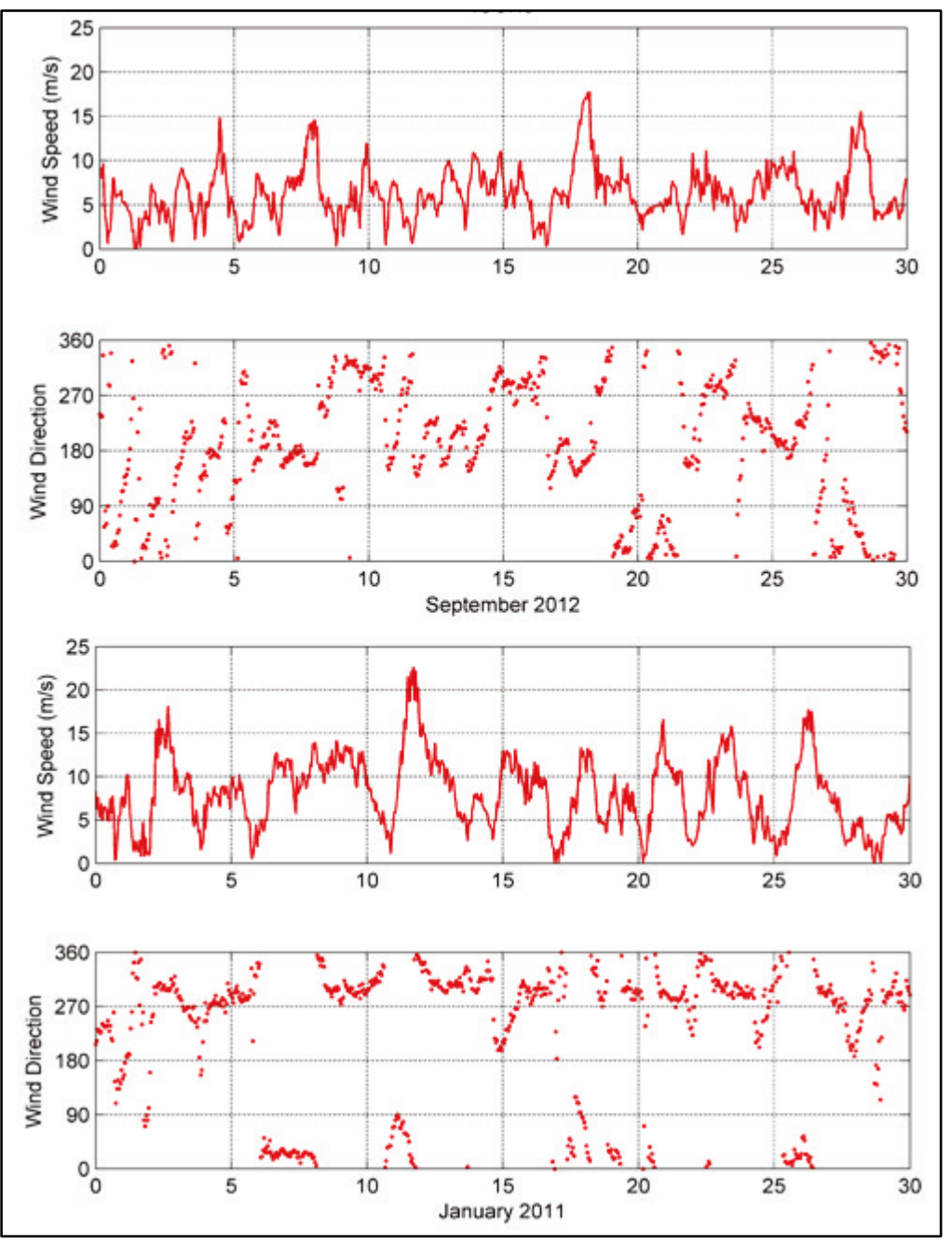


Figure 12. Wind speeds and directions at NDBC buoy IOSN3, December 2014 - June 2015.

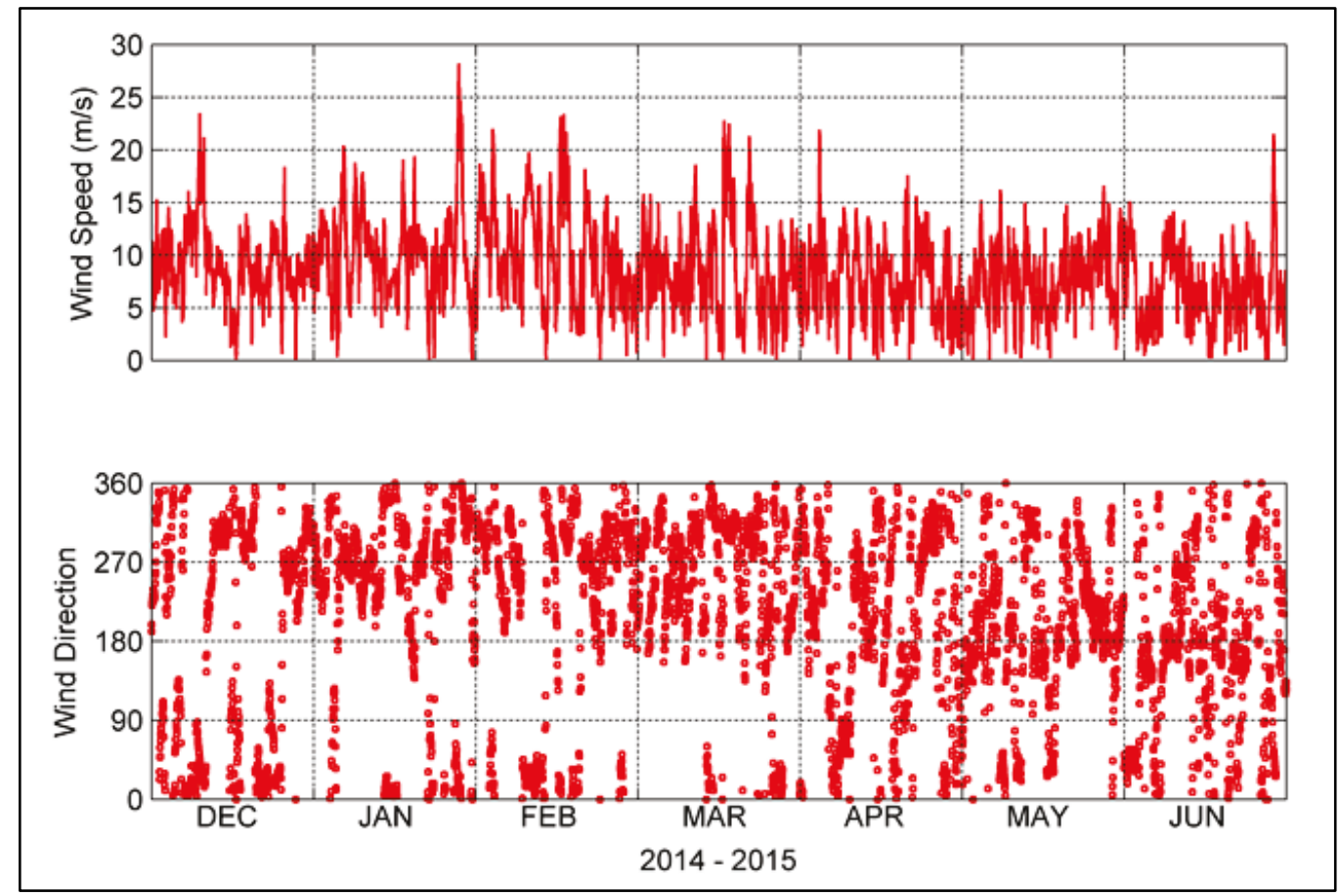

WSE data were downloaded from NOAA tide gauge \#8423898 at Fort Point, NH (http://tidesandcurrents.noaa.gov, accessed December 2016) and are shown in Figure 7. A semi-diurnal tidal regime is characteristic of the study area. The WSEs in the months of September 2012 and January 2011 and between December 2014 and June 2015 are shown in Figure 13 and Figure 14, respectively, illustrating similar spring and neap tidal ranges. The mean tidal range (mean high water - mean low water) is $2.63 \mathrm{~m}$ $(8.63 \mathrm{ft})$, and the maximum tidal range (mean higher high water - mean lower low water) is $2.87 \mathrm{~m}(9.42 \mathrm{ft})$. 
Figure 13. WSE at NOAA tide gauge \#8423898, Fort Point, NH, September 2012 and January 2011.

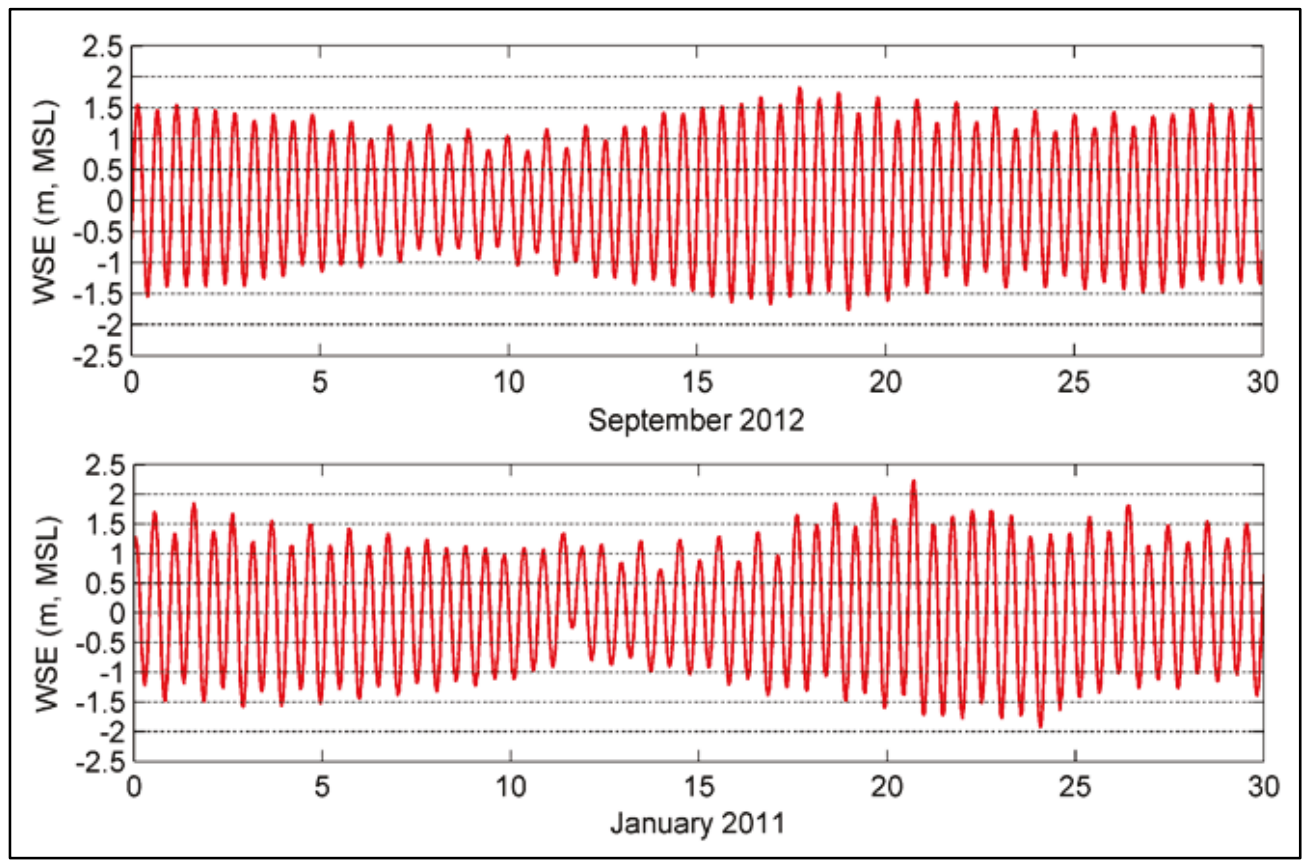

Figure 14. WSE at NOAA tide gauge \#8423898, Fort Point, NH, December 2014 and June 2015.

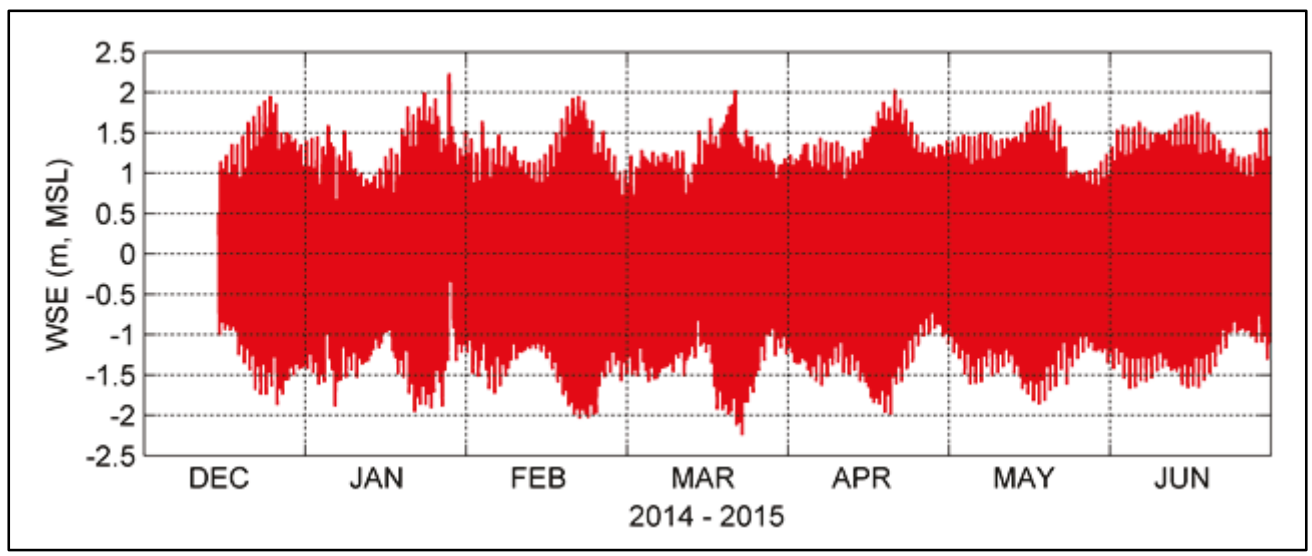

River flow data were obtained from the U.S. Geological Survey (USGS) gauges at the Merrimack, Mill, Parker, and Ipswich Rivers (Figure 5). Figure 15 shows the flow discharge at the Merrimack River gauge for September 2012 and January 2011; Figure 16 shows the flow discharge at the four river gauges for the time period between December 2014 and June 2015. The flow discharge at the Merrimack River can be more than $1,000 \mathrm{~m} 3 / \mathrm{s}(35,314 \mathrm{ft} 3 / \mathrm{s})$ during the high flow season and is 1 to 2 orders of magnitude larger than the other rivers. The winter-spring discharge can be 2 to 3 times the average summer-fall discharge. 
Figure 15. River inflow at USGS gauge, Merrimack River, September 2012 and January 2011.

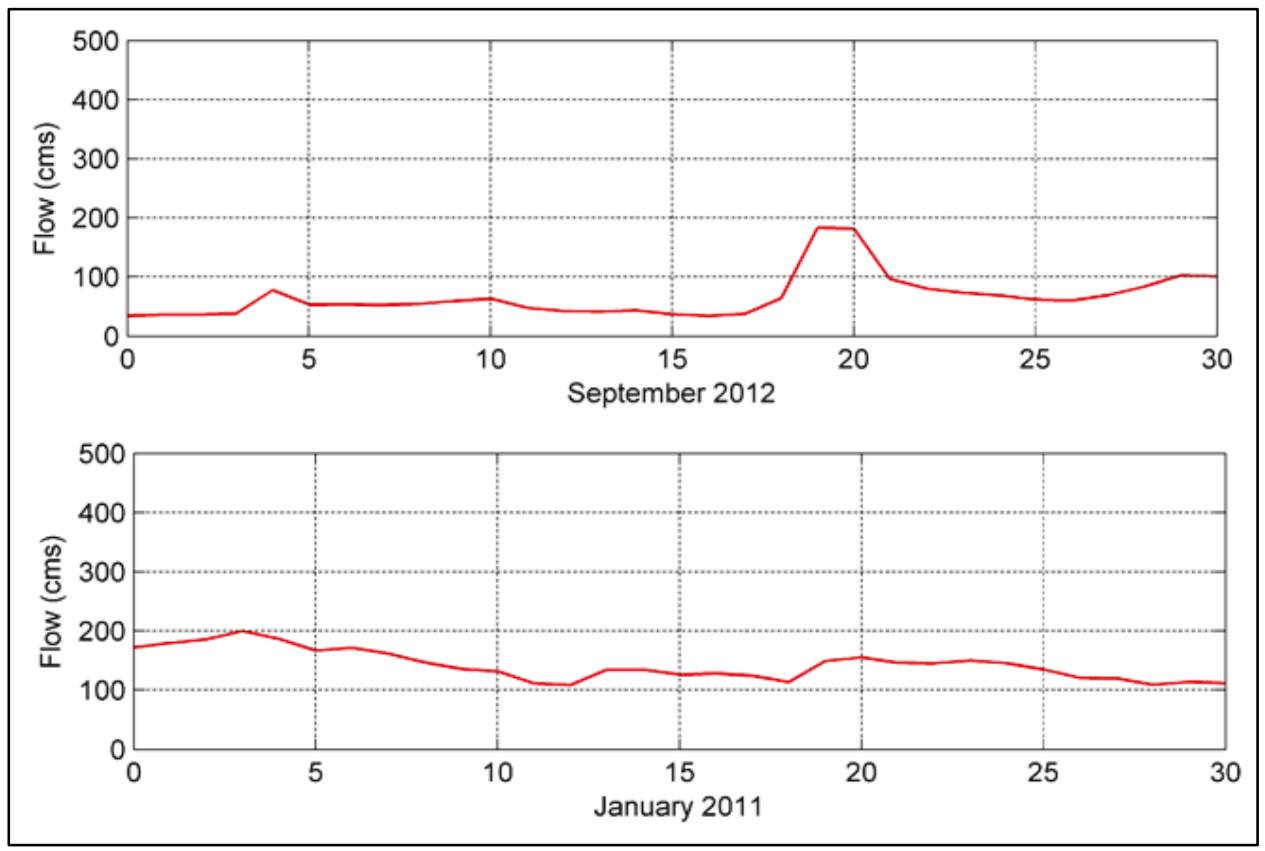

Figure 16. River inflow at USGS gauges, Merrimack River, Mill River, Parker River, and Ipswich River, December 2014 and June 2015.

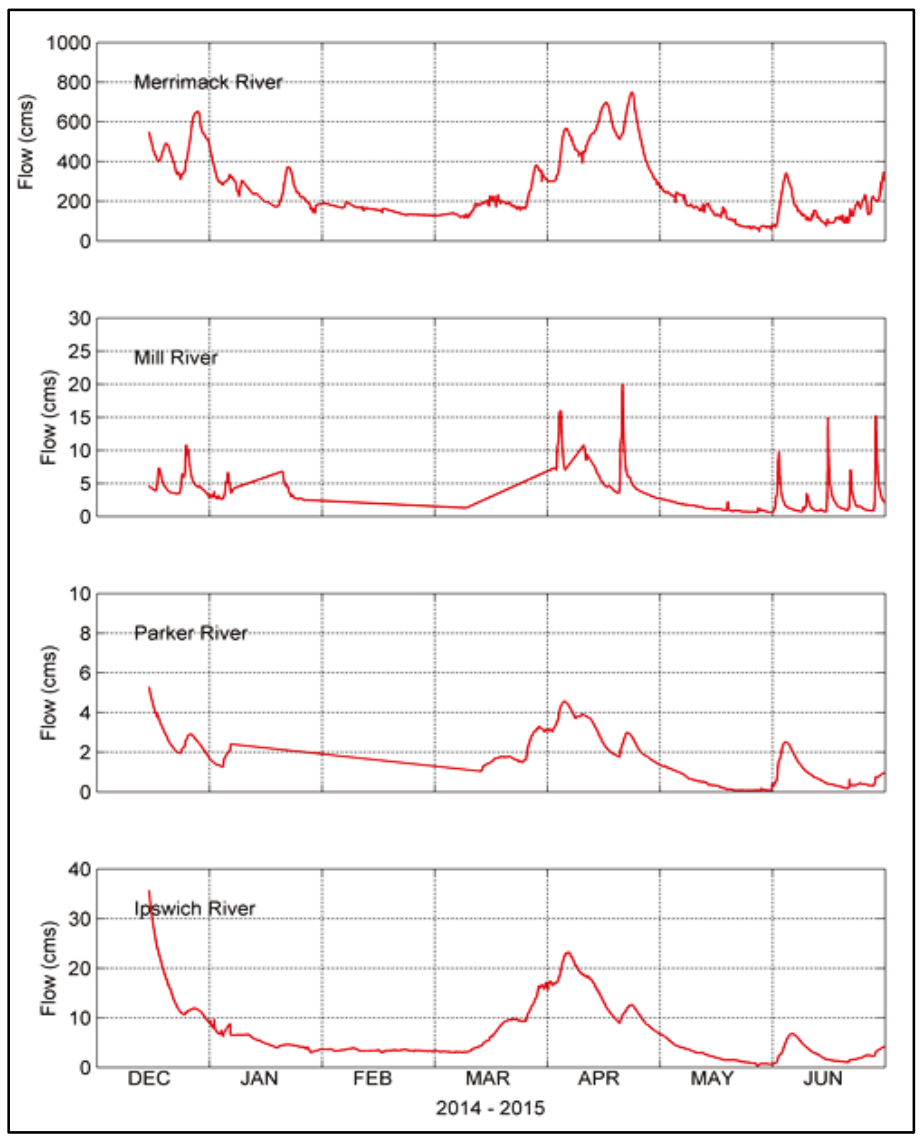


A field data survey was conducted by Woods Hole Group, a private engineering firm. Four water level gauges were deployed in the Plum Island Sound from September through December 2012. Three acoustic Doppler current profilers (ADCPs) were deployed around the inlet system. One was in the center of the channel and two were around the South Jetty from September through October 2012 (Figure 17 and Figure 18). The channel ADCP was lost due to strong current, and those data were unavailable for use in calibration and validation processes. WSE and current data were collected from the two ADCPs around the South Jetty. Besides the hydrographic data, sediment grab samples were collected in north Plum Island Sound (Figure 19). Based on 17 samples, a $D_{50}$ of 0.32 millimeters $(\mathrm{mm})$ was calculated for the Sound area, and this value was applied to the Phase 1 numerical modeling study.

Figure 17. Locations of water level gauge stations.

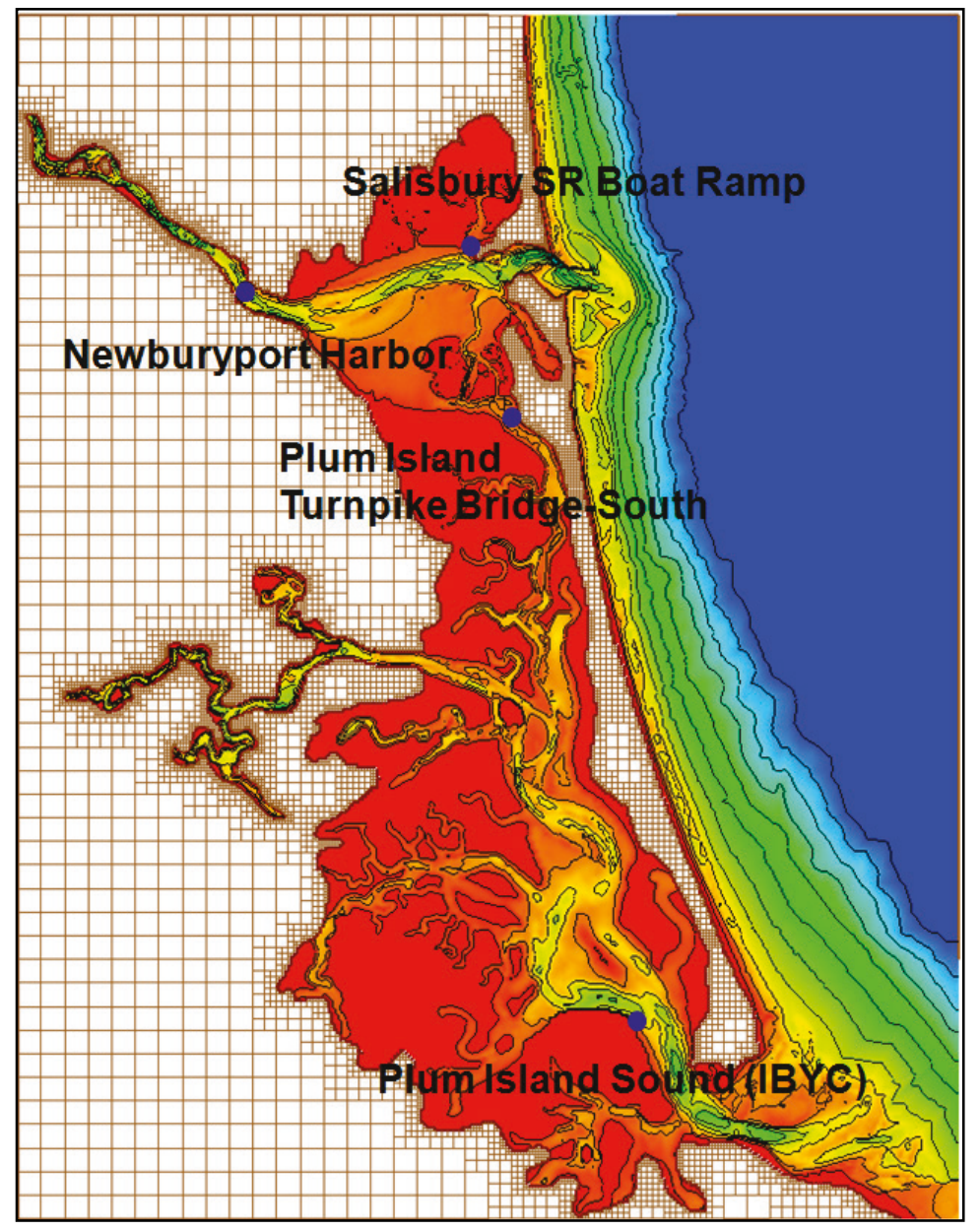


Figure 18. Locations of deployed inlet and downdrift ADCP gauges.

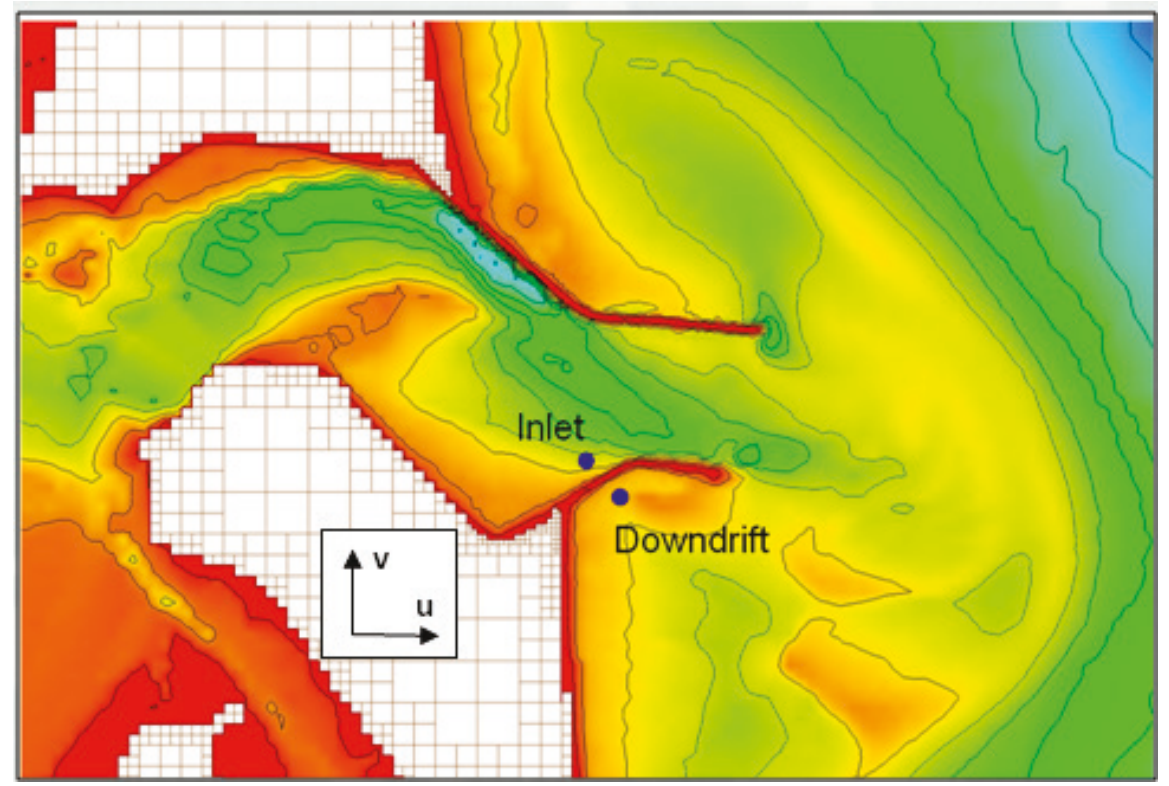

Figure 19. Sediment grab sampling locations in north Plum Island Sound.

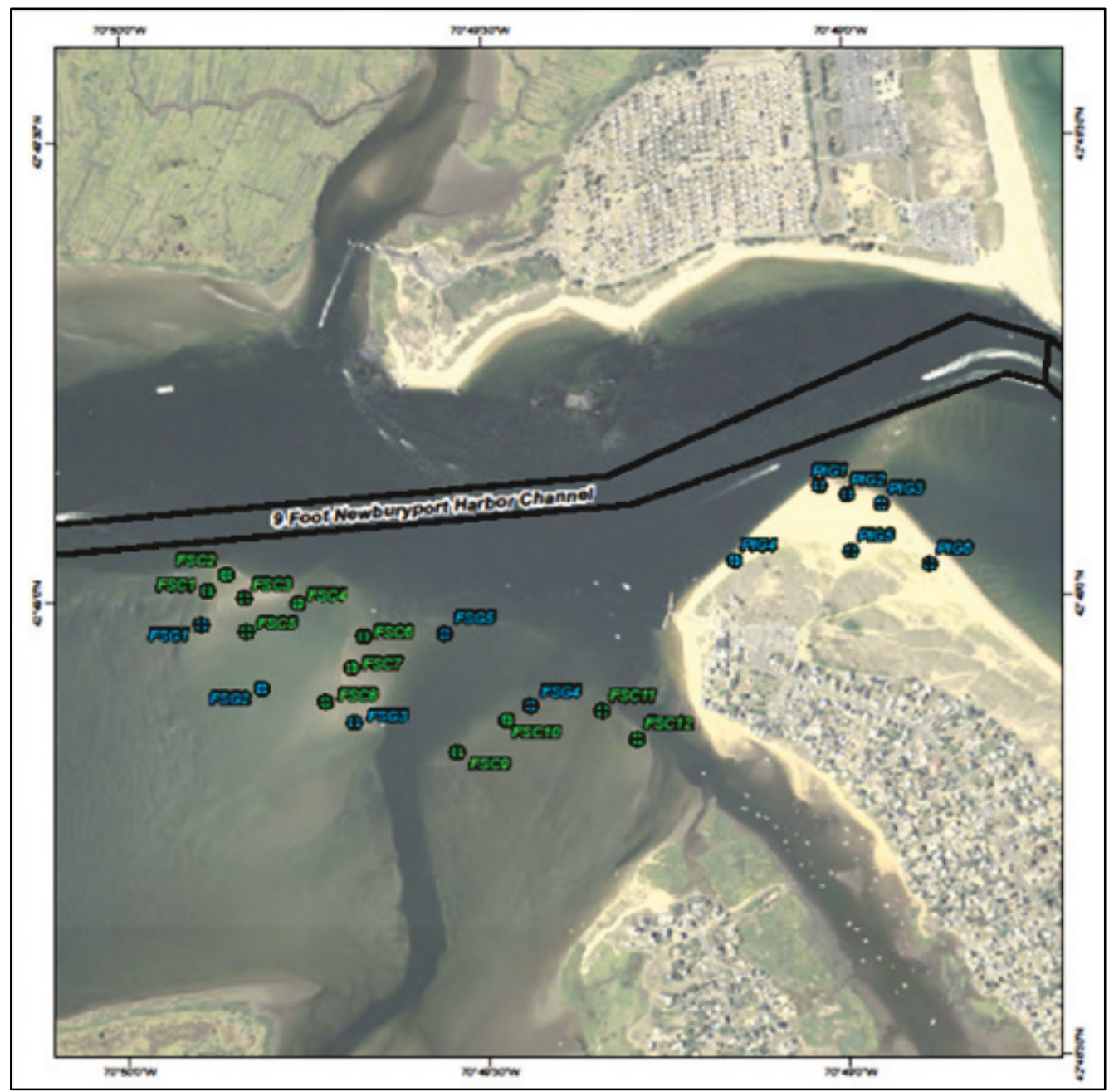


For the Phase II study, NAE provided sediment grain size distribution data in the Newburyport navigation channel ${ }^{1}$. Additional grain size data were obtained from the USGS (2016), which were collected at mouth of Merrimack River and on the shelf in 2009-2011. Figure 20 shows the $D_{50}$ distributions of the two datasets. Within the inlet channel, sediment grain size is coarse, and on average the $D_{50}$ grain size is greater than $1 \mathrm{~mm}$. Landward of the inlet, towards Plum Island Sound, $D_{50}$ is finer and increases with proximity to the mouth of Merrimack River. Medium- to fine-sand grain sizes are found in front of Salisbury Beach, with an average mean that is less than $0.2 \mathrm{~mm}$. To the south of Merrimack Inlet, the $D_{50}$ along Plum Island beaches ranges between 0.5 and $1.0 \mathrm{~mm}$. Coarse sand grain sizes were also found across the offshore area with $D_{50}$ values ranging between 0.5 and $1.0 \mathrm{~mm}$ (Figure 20).

Figure 20. Sediment grab sampling locations and $D_{50}$ distributions in (a) Newburyport navigation channel and (b) at mouth of Merrimack River.

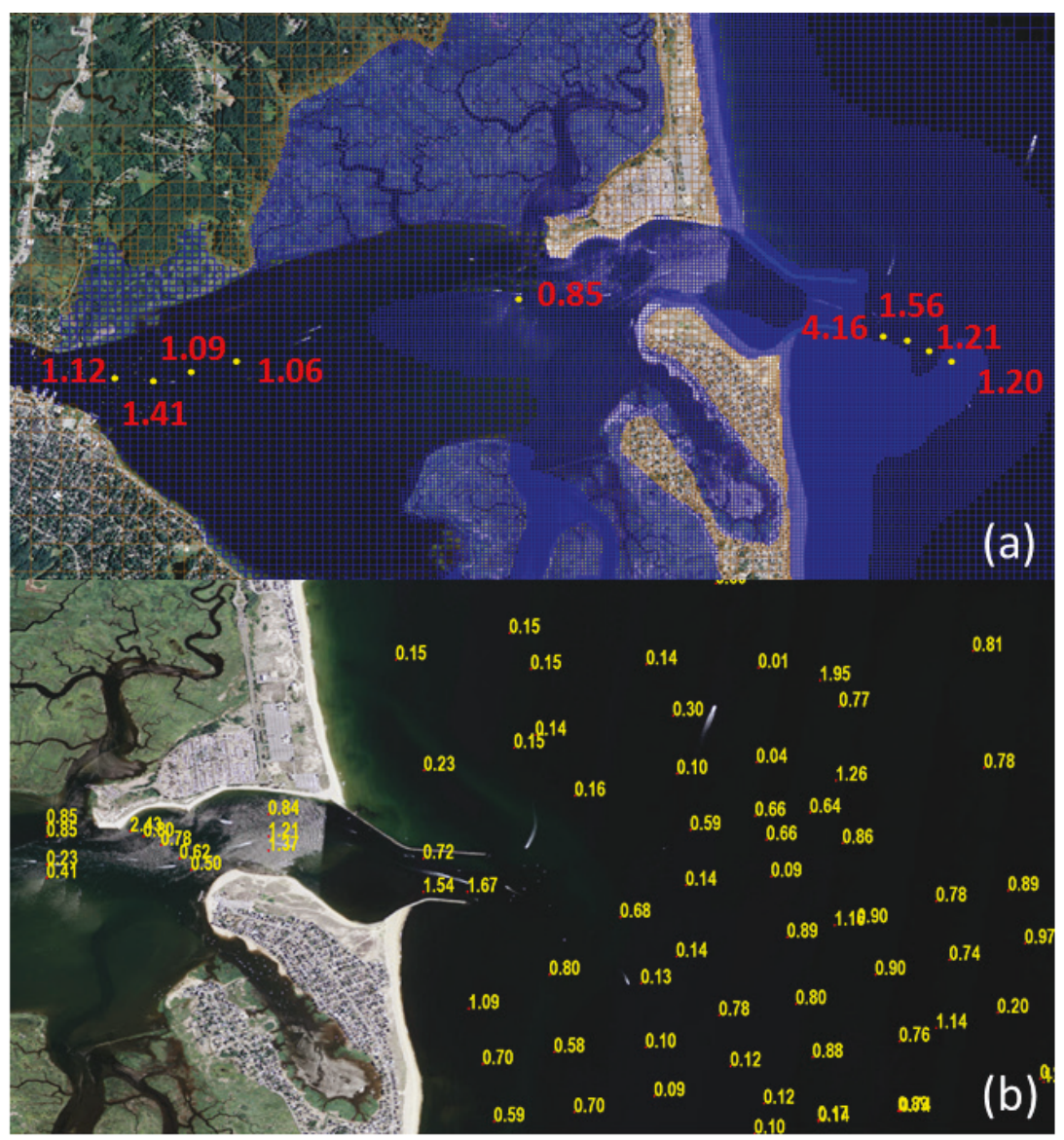

\footnotetext{
1 Edward O’Donnell; NAE; personal communication; 16 August 2016.
} 
In Phase I, the bed grain size distribution was based on limited initial datasets (Figure 19). A constant grain size was selected for sediment transport. The improved bed grain size distribution data informed Phase II, and sediment grain sizes were specified for the bed and in the multi-grain size sediment transport model for Phase II simulations.

\subsection{Simulations}

\subsubsection{Phase I}

\subsubsection{Pre-rehabilitation (existing) condition}

The pre-rehabilitation condition of the jetties was used as the existing condition for the CMS calibration and validation. The jetty condition survey was derived from 2011 lidar data. Calibration of the CMS was conducted for the month of September 2012, followed by a validation run for the month of October 2012 (Table 2-1). Both calibration and validation were based on measured water levels and currents collected during the field study (see Section 2.4).

Based on the analysis of historical wave, wind, and freshwater inflow data, one representative summer-fall, low-energy month (September 2012) and one winter, high-energy month (January 2011) were selected. The two month-long simulations provided a baseline for initial comparisons of the 19 alternatives (Table $2-1$ ).

Table 2-1. Summary of model simulations for the pre-rehabilitation (existing) condition.

\begin{tabular}{|l|l|l|}
\hline Simulation & Period & Notes \\
\hline Calibration & September 2012 & Field measurements, rehabilitated South Jetty \\
\hline Validation & October 2012 & Field measurements, rehabilitated South Jetty \\
\hline $\begin{array}{l}\text { Representative } \\
\text { summer-fall month }\end{array}$ & September 2012 & Rehabilitated South Jetty \\
\hline $\begin{array}{l}\text { Representative winter } \\
\text { month }\end{array}$ & January 2011 & Rehabilitated South Jetty \\
\hline
\end{tabular}

\subsubsection{Partial-rehabilitation of South Jetty}

During the course of the Phase I numerical modeling study, the South Jetty at Merrimack Inlet was partially rehabilitated. Jetty rock was sand tightened through additional stone placement, and the overall jetty crest height was raised to designed levels. Only part of the South Jetty received 
this treatment during the time of Phase I. The remainder of the rehabilitation was completed later, and the fully rehabilitated South Jetty condition was used in the Phase II study.

A total of 19 alternatives were developed and evaluated using the partially rehabilitated South Jetty condition (Figure 21). The representative winter month (January 2011) and the winter-spring period (January-June 2011) were simulated for the 19 alternatives with the partially rehabilitated South Jetty. The representative summer month was not considered for this set of alternatives.

Figure 21. Partially rehabilitated South Jetty condition used for the representative winter month and the winter-spring period simulations of the 19 alternatives.

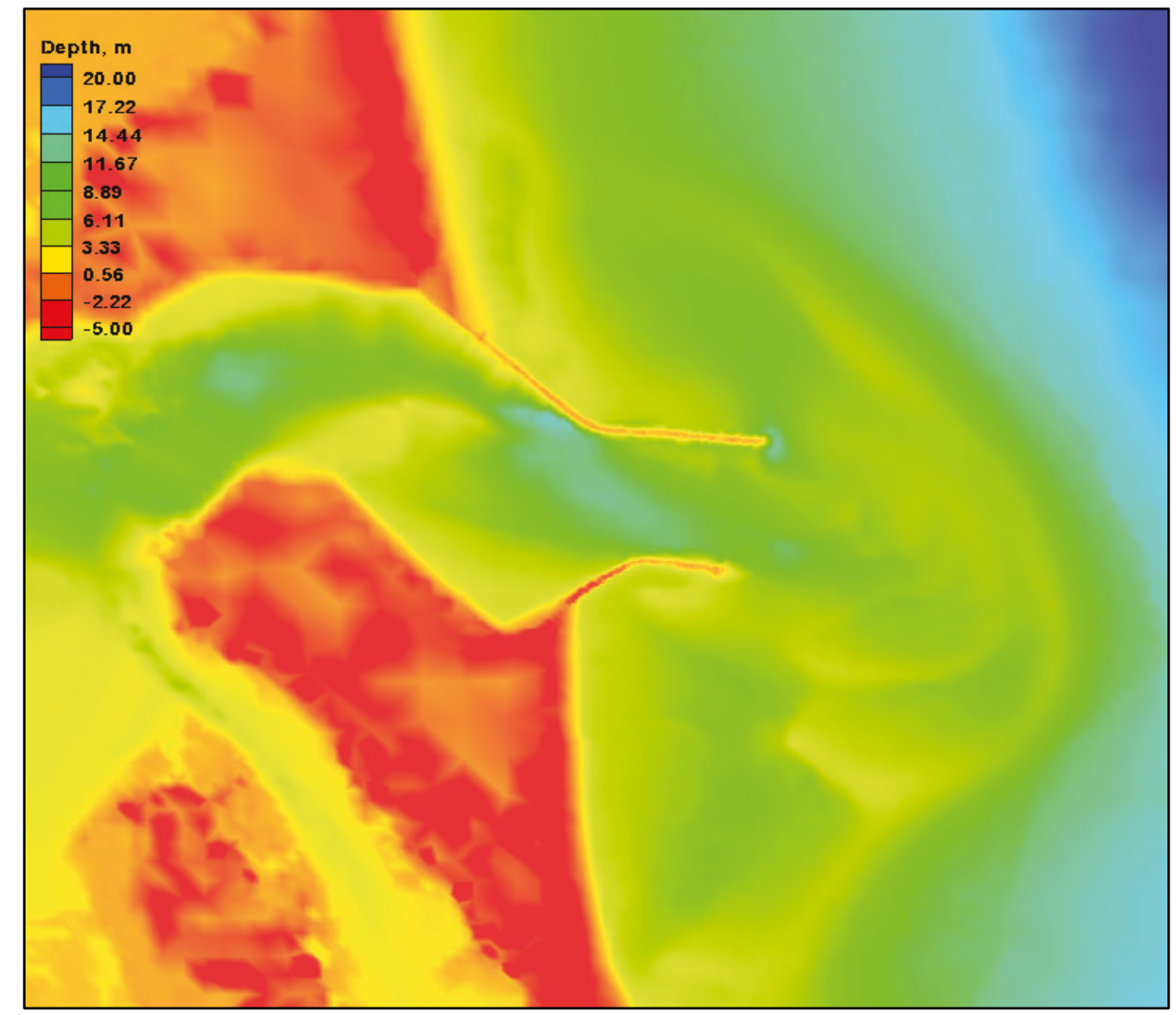

\subsubsection{Sediment management alternatives}

A successful sediment management alternative is defined for this study as one that reduces erosion of the adjacent beaches, increases performance of the jetties, and decreases shoaling in the inlet. This undertaking leaves room for the investigation of a plethora of alternatives to meet these multiple objectives, which is why a total of 19 alternatives were developed. To investigate how alternative designs might be utilized to benefit navigation 
and sand management strategies for the inlet and adjacent beaches, the 19 alternatives have been grouped for discussion for the Phase I study.

The first group consists of a series of sediment management alternatives that were developed to examine potential borrow sources for beach nourishment, in which sand was mined from the ebb tidal delta, the North Point (interior shoal adjacent to the navigation channel), or the flood tidal delta, and was placed on Salisbury Beach or Plum Island Beach. The approximate locations of these mining and placement sites and volumes are shown in Figure 22. Alternative 6 evaluates the benefits and implications of having a sedimentation basin inside the South Jetty. Table 2-2 lists the alternatives in this group and gives a description of each. Note that the sediment volumes for each alternative are given in cubic yards (CY, in Figure 22) for clarity of the reader familiar with English units commonly used in USACE dredging and placement projects.

Figure 22. Placement locations for Alternatives 1-6.

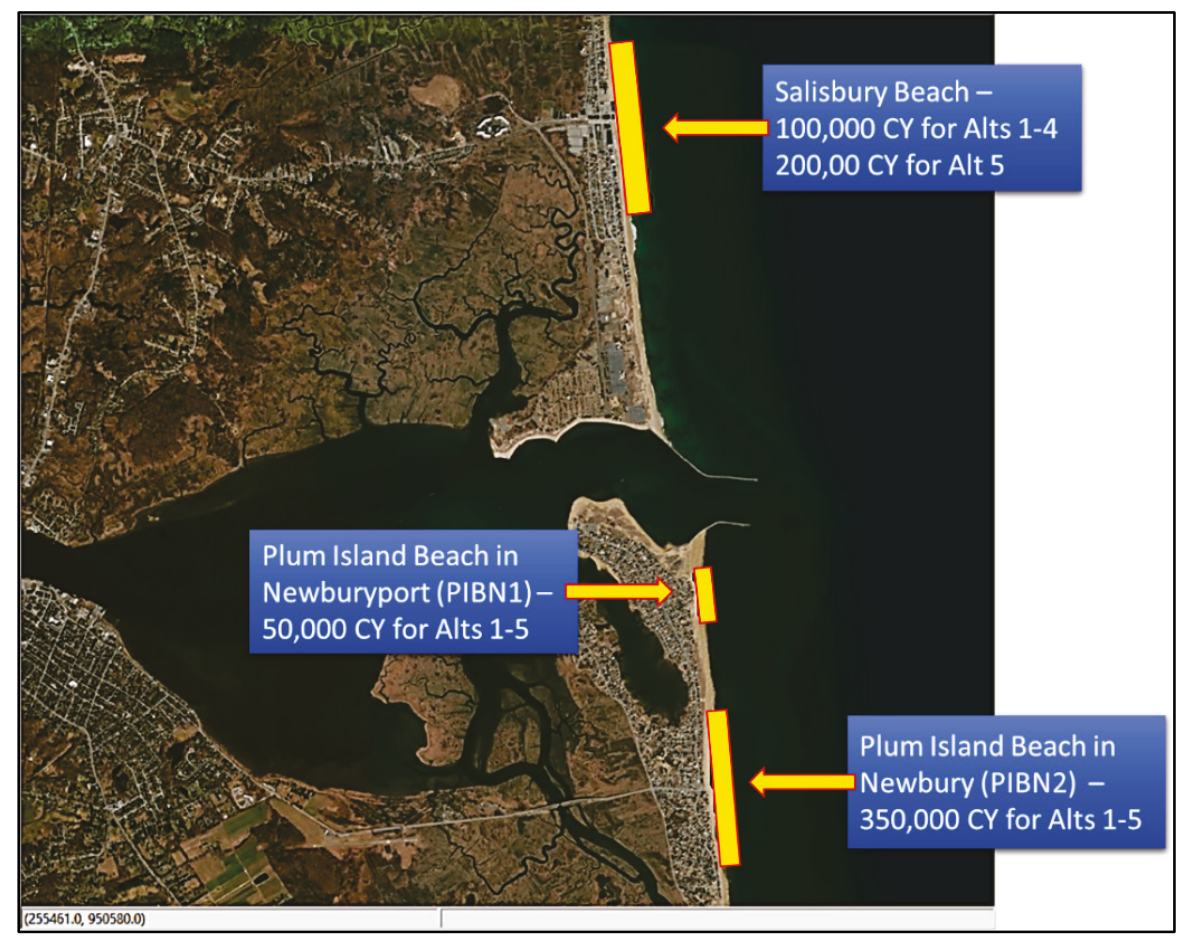


Table 2-2. Sediment management alternatives and their descriptions.

\begin{tabular}{|c|c|c|}
\hline Alternative & Description & Notes \\
\hline 1 & $\begin{array}{l}\text { Mine ebb delta up to } 382 \mathrm{~K} \mathrm{~m}^{3} \\
\text { (500K cu yd) }\end{array}$ & $\begin{array}{l}\text { Place } 76 \mathrm{~K} \mathrm{~m}^{3} \text { (100K cu yd) on Salisbury, } 38 \mathrm{~K} \mathrm{~m}^{3} \\
\text { (50K cu yd) on Plum Island Beach in Newburyport } \\
\text { (PIBN1), and } 268 \mathrm{~K} \mathrm{~m}^{3}(350 \mathrm{~K} \text { cu yd) on Plum Island } \\
\text { Beach in Newbury (PIBN2), Figure } 23\end{array}$ \\
\hline 2 & $\begin{array}{l}\text { Mine flood delta up to } 382 \mathrm{~K} \mathrm{~m}^{3} \\
\text { (500K cu yd) }\end{array}$ & $\begin{array}{l}\text { Same placement scenario as Alt } 1 \text {, } \\
\text { Figure } 24 .\end{array}$ \\
\hline 3 & $\begin{array}{l}\text { Mine North Point, Plum Island up to } \\
382 \mathrm{~K} \mathrm{~m}^{3}(500 \mathrm{~K} \mathrm{cu} \text { yd })\end{array}$ & $\begin{array}{l}\text { Same placement scenario as Alt } 1 \text {, } \\
\text { Figure } 25 .\end{array}$ \\
\hline 4 & $\begin{array}{l}\text { Mine nearshore bars } 382 \mathrm{~K} \mathrm{~m}^{3} \\
\text { (500K cu yd) }\end{array}$ & $\begin{array}{l}\text { Same placement scenario as Alt } 1 \text {, } \\
\text { Figure } 26 .\end{array}$ \\
\hline 5 & $\begin{array}{l}\text { Mine } 153 \mathrm{~K} \mathrm{~m}^{3}(200 \mathrm{~K} \text { cu yd) each from } \\
\text { Ebb delta, Flood Delta and North Point of } \\
\text { Plum Island }\end{array}$ & $\begin{array}{l}\text { Place } 153 \mathrm{~K} \mathrm{~m}^{3}\left(200 \mathrm{~K} \text { cu yd) on Salisbury, } 38 \mathrm{~K} \mathrm{~m} \mathrm{~m}^{3}\right. \\
\text { (50K cu yd) on PIBN1, and } 268 \mathrm{~K} \mathrm{~m} \mathrm{~m}^{3}(350 \mathrm{~K} \text { cu yd) } \\
\text { on PIBN2, Figure } 27 .\end{array}$ \\
\hline 6 & $\begin{array}{l}\text { Construct sedimentation basin inside } \\
\text { South Jetty with capacity } 229 \mathrm{~K} \mathrm{~m}^{3} \\
\text { (300K cu yd) }\end{array}$ & $\begin{array}{l}\text { Dredged to } 7.5 \mathrm{~m}(24.6 \mathrm{ft}) \text { below MSL, } \\
\text { Figure } 28 .\end{array}$ \\
\hline
\end{tabular}

Ebb Delta Mining, Alternative 1

In this sediment alternative, $382,277 \mathrm{~m}^{3}$ (500,000 cu yd) of material were removed from the southern portion of the ebb tidal delta (Figure 23). The sand was placed in three separate locations in the nearshore, approximately $76,455 \mathrm{~m}^{3}$ (100,000 cu yd) offshore of Salisbury Beach, 38,228 m³ (50,000 cu yd) offshore of PIBN1, and 267,594 m³ (350,000 cu yd) offshore of PIBN2, respectively. The purpose of this simulation was to examine the potential effects that removing a portion of the ebb tidal shoal would have on the sand-sharing system including the downdrift bars, navigation channel shoaling, and wave and current patterns within the navigation channel. 
Figure 23. Alternative 1: Ebb delta mining and placement (in this figure, $\mathrm{CY}=$ cubic yards).

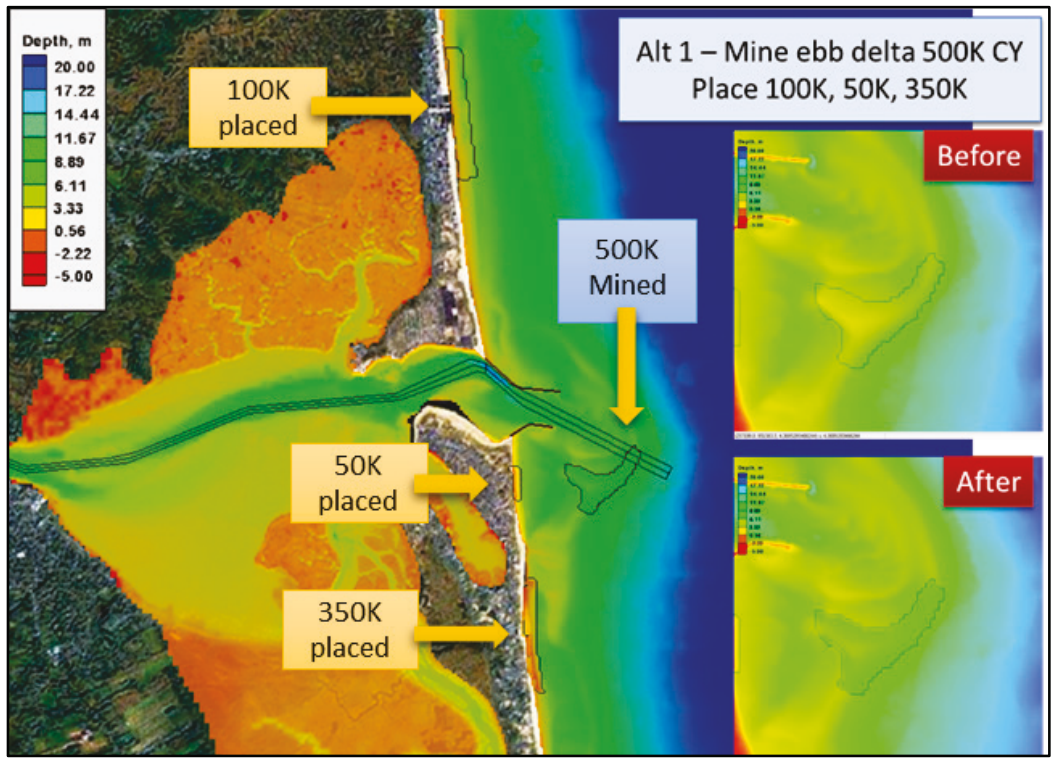

\section{Flood Delta Mining, Alternative 2}

Flood tidal delta shoals within the estuary, located due west of Plum Island, contain a significant volume of sediment. This alternative was designed to mine up to $382,277 \mathrm{~m}^{3}$ (500,000 cu yd) of sediment from these shoals. Figure 24 shows the location of the mined flood tidal delta shoal and the three placement locations. The volumes placed are the same as for the ebb delta mining alternative.

Figure 24. Alternative 2: Flood delta mining and placement (in this figure, $\mathrm{CY}=$ cubic yards).

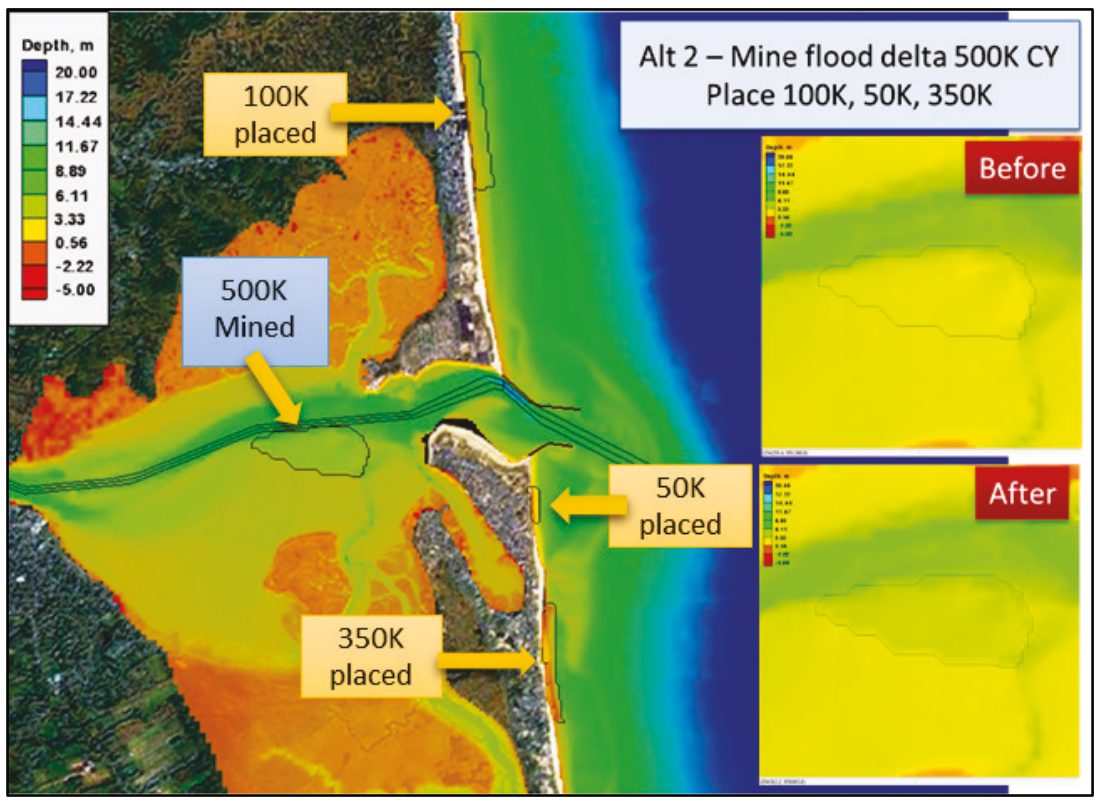


North Point, Plum Island Mining, Alternative 3

As described in the shoreline evolution section, the northern portion of Plum Island has grown substantially in the past decade. This alternative was designed to mine $382,277 \mathrm{~m}^{3}$ (500,000 cu yd) of material from the northern end of the barrier island. Figure 25 shows the mining location and the three placement locations. The same volumes were placed at each nearshore location as the ebb and flood mining alternatives (Alternatives 1 and 2).

Figure 25. Alternative 3: North Point (in this figure, $\mathrm{CY}=$ cubic yards).

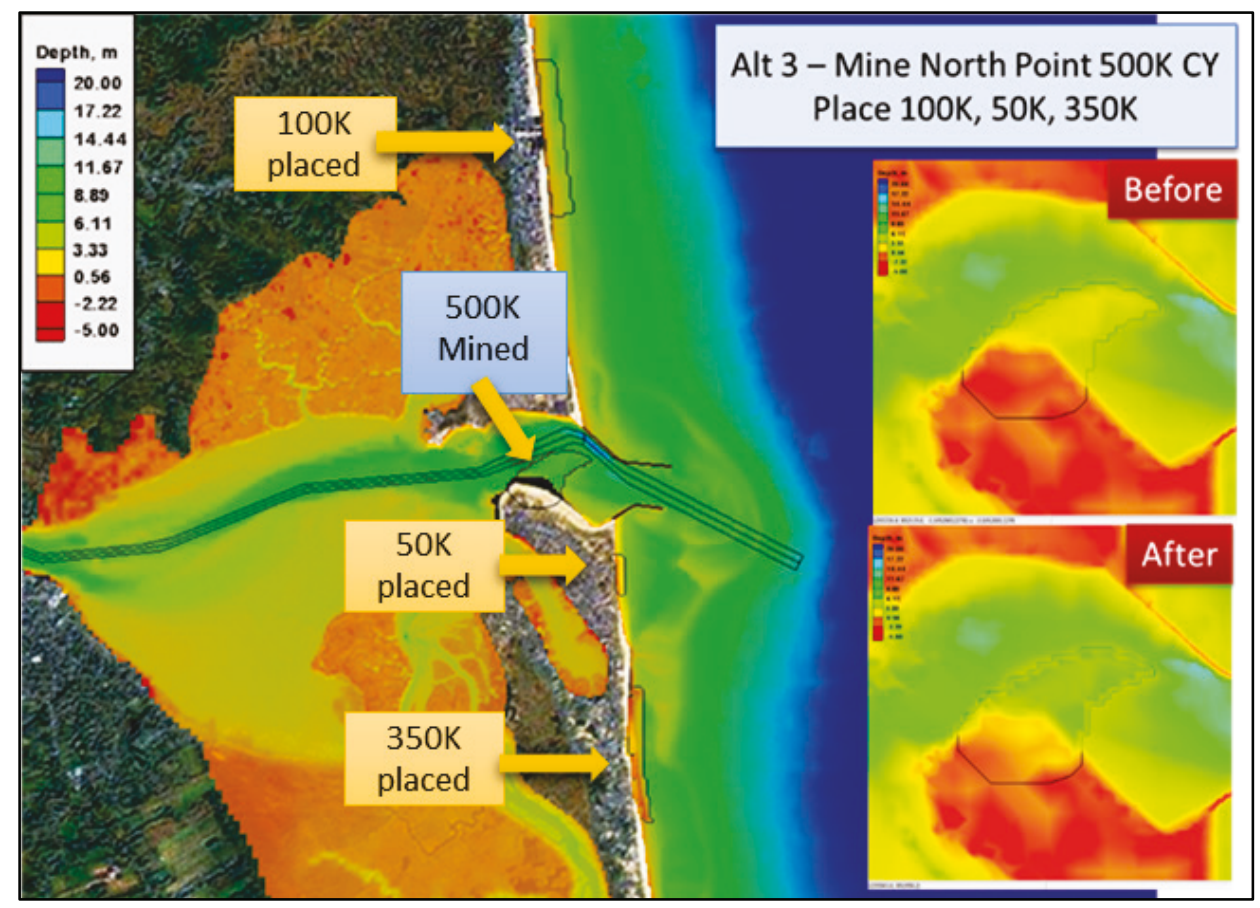

Nearshore Bar Mining, Alternative 4

Sediment in the nearshore region located south of Merrimack Inlet has been largely immobile in recent decades ${ }^{1}$. This alternative was set up to mine $382,277 \mathrm{~m}^{3}$ (500,000 cu yd) of sediment from the nearshore bar. Figure 26 shows the location of the nearshore bar relative to Merrimack Inlet, which is located very close to the Plum Island Newbury placement site. Salisbury Beach received 76,455 $\mathrm{m}^{3}$ (100,ooo cu yd); 38,228 $\mathrm{m}^{3}$ (50,000 cu yd) and 267,594 m³ (350,000 cu yd) were placed on PIBN1 and PIBN2, respectively.

\footnotetext{
1 Irene Watts; NAE; personal communication; March 2013.
} 
Figure 26. Alternative 4: Mine nearshore bars and placement locations (in this figure, $\mathrm{CY}=$ cubic yards).

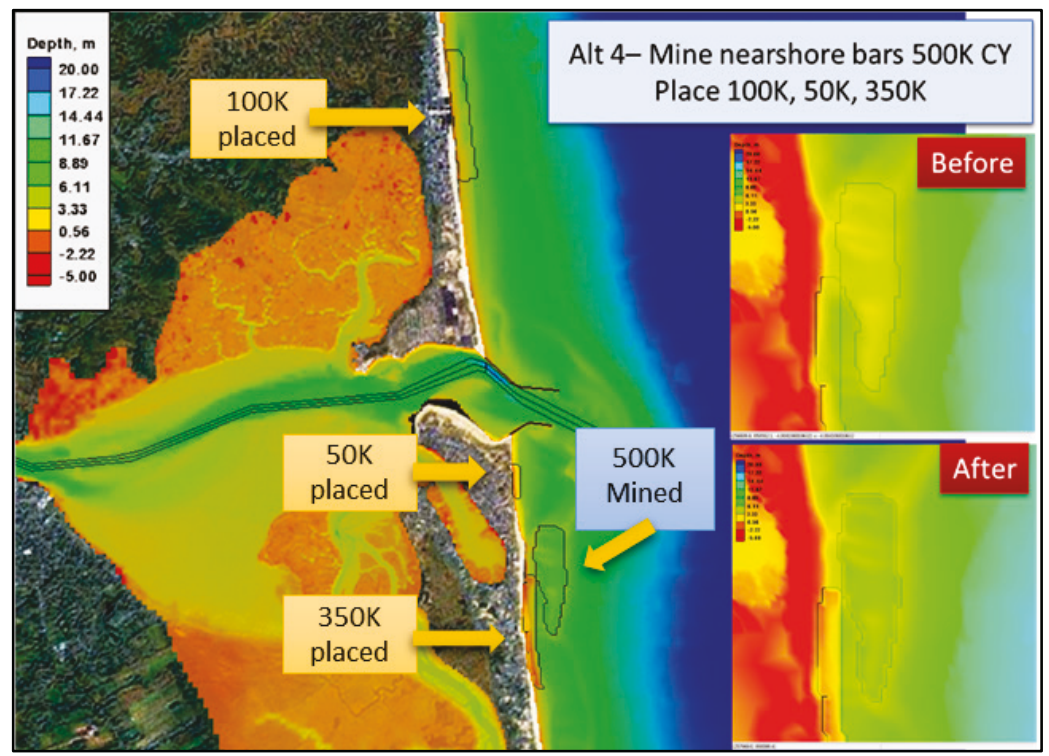

\section{Multiple Mining Locations, Alternative 5}

In this alternative a total of $458,733 \mathrm{~m}^{3}$ (600,000 cu yd) were removed, $152,911 \mathrm{~m}^{3}$ (200,000 cu yd) each from the ebb tidal delta, flood tidal delta, and the North point. The mining and the placement locations are shown in Figure 27. Approximately 152,911 $\mathrm{m}^{3}$ (200,000 cu yd) was placed on Salisbury Beach, 38,228 $\mathrm{m}^{3}$ (50,000 cu yd) was placed on PIBN1, and $267,594 \mathrm{~m}^{3}$ (350,000 cu yd) was placed on PIBN2.

Figure 27. Alternative 5: Multiple mining locations and placement (in this figure, $\mathrm{CY}=$ cubic yards).

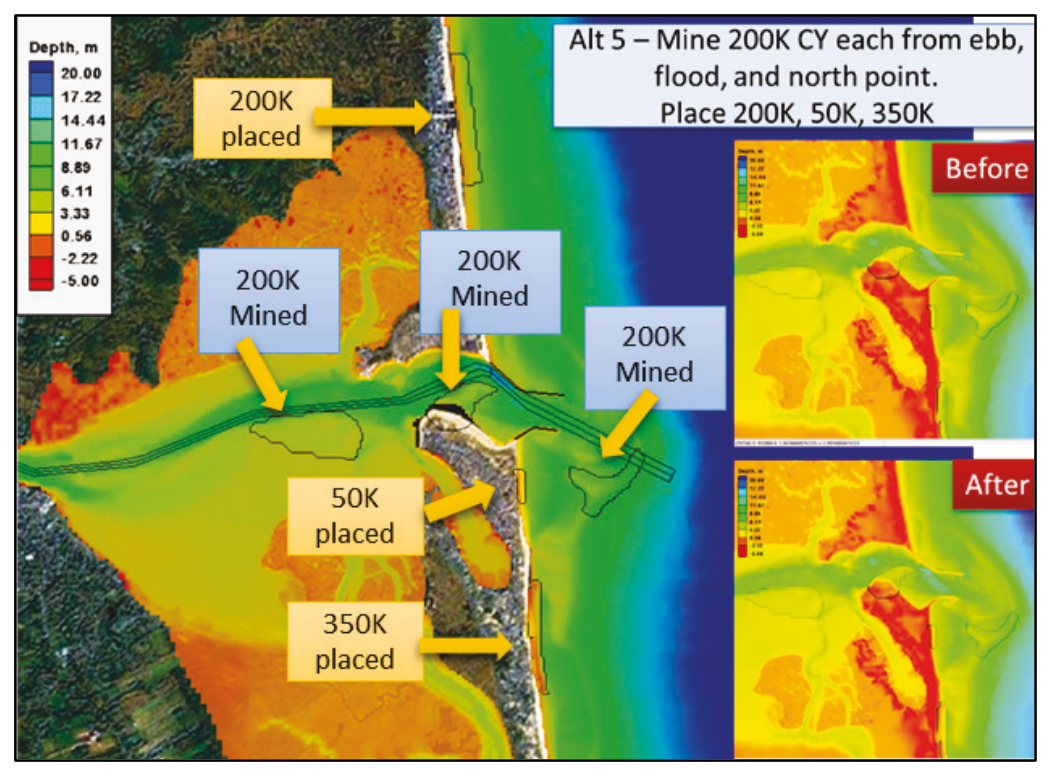




\section{Sedimentation Basin, Alternative 6}

In this alternative a sedimentation basin was dredged to $7.5 \mathrm{~m}(24.6 \mathrm{ft})$ below MSL inside of the South Jetty, and the capacity of the basin was $229,366 \mathrm{~m}^{3}$ (300,000 cu yd). The design of the basin is shown in Figure 28.

Figure 28. Alternative 6: Sedimentation basin located landward of the South Jetty (in this figure, $\mathrm{CY}=$ cubic yards).

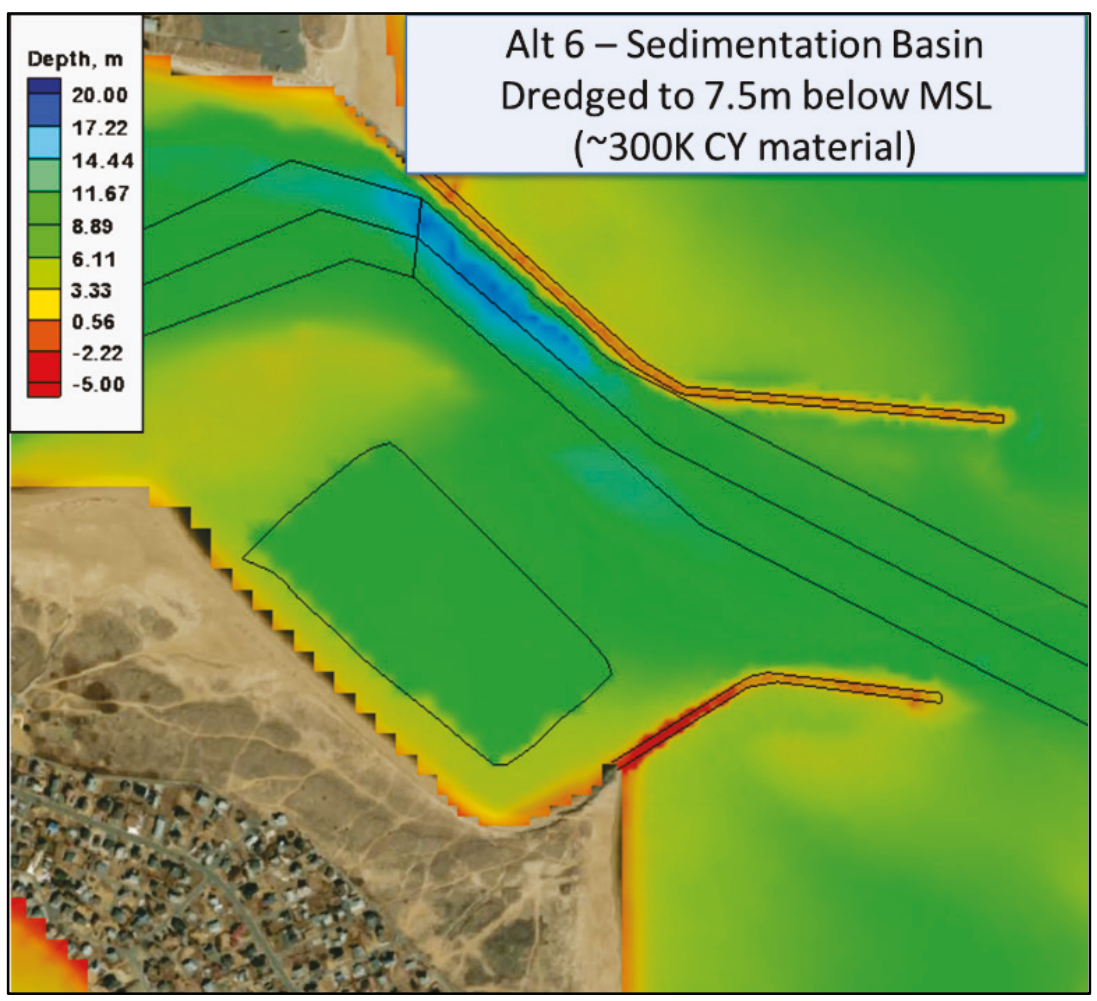

\subsubsection{Structure modification alternatives}

The second group of alternatives contains the modification of existing structures and the addition of detached breakwaters located south of the South Jetty (Table 2-3). 
Table 2-3. Structure modification alternatives and their descriptions.

\begin{tabular}{|c|l|l|}
\hline Alternative & Description & Notes \\
\hline 7 & Remove jetties & Figure 29 \\
\hline 8 & Lengthen jetties by $152 \mathrm{~m}(500 \mathrm{ft})$ & Figure 30 \\
\hline 9 & Remove outer portion of jetties & $\begin{array}{l}\text { Approximately } 384 \mathrm{~m}(1,260 \mathrm{ft}) \text { on the North } \\
\text { Jetty and } 198 \mathrm{~m}(650 \mathrm{ft}) \text { on the South Jetty, } \\
\text { Figure 31. }\end{array}$ \\
\hline 10 & $\begin{array}{l}\text { Reorient jetties to match alignment of the } \\
\text { navigation channel }\end{array}$ & Figure 32 \\
\hline 11 & $\begin{array}{l}\text { Add } 152 \mathrm{~m}(500 \mathrm{ft}) \text { length dogleg on North } \\
\text { Jetty }\end{array}$ & Figure 33 \\
\hline 12 & $\begin{array}{l}\text { Add } 152 \mathrm{~m}(500 \mathrm{ft}) \text { length dogleg on both } \\
\text { jetties }\end{array}$ & Figure 34 \\
\hline 13 & Add $76 \mathrm{~m}(250 \mathrm{ft})$ spur inside North Jetty & Figure 35 \\
\hline 14 & Add $76 \mathrm{~m}(250 \mathrm{ft})$ spur outside South Jetty & Figure 36 \\
\hline 15 & $\begin{array}{l}\text { Add four detached breakwaters offshore } \\
\text { of Plum Island }\end{array}$ & Figure 37 \\
\hline
\end{tabular}

\section{Jetty Removal, Alternative 7}

The first of the structure alternatives was the complete removal of the jetties. Figure 29 illustrates the inlet without the presence of jetties.

Figure 29. Alternative 7: Jetty removal.

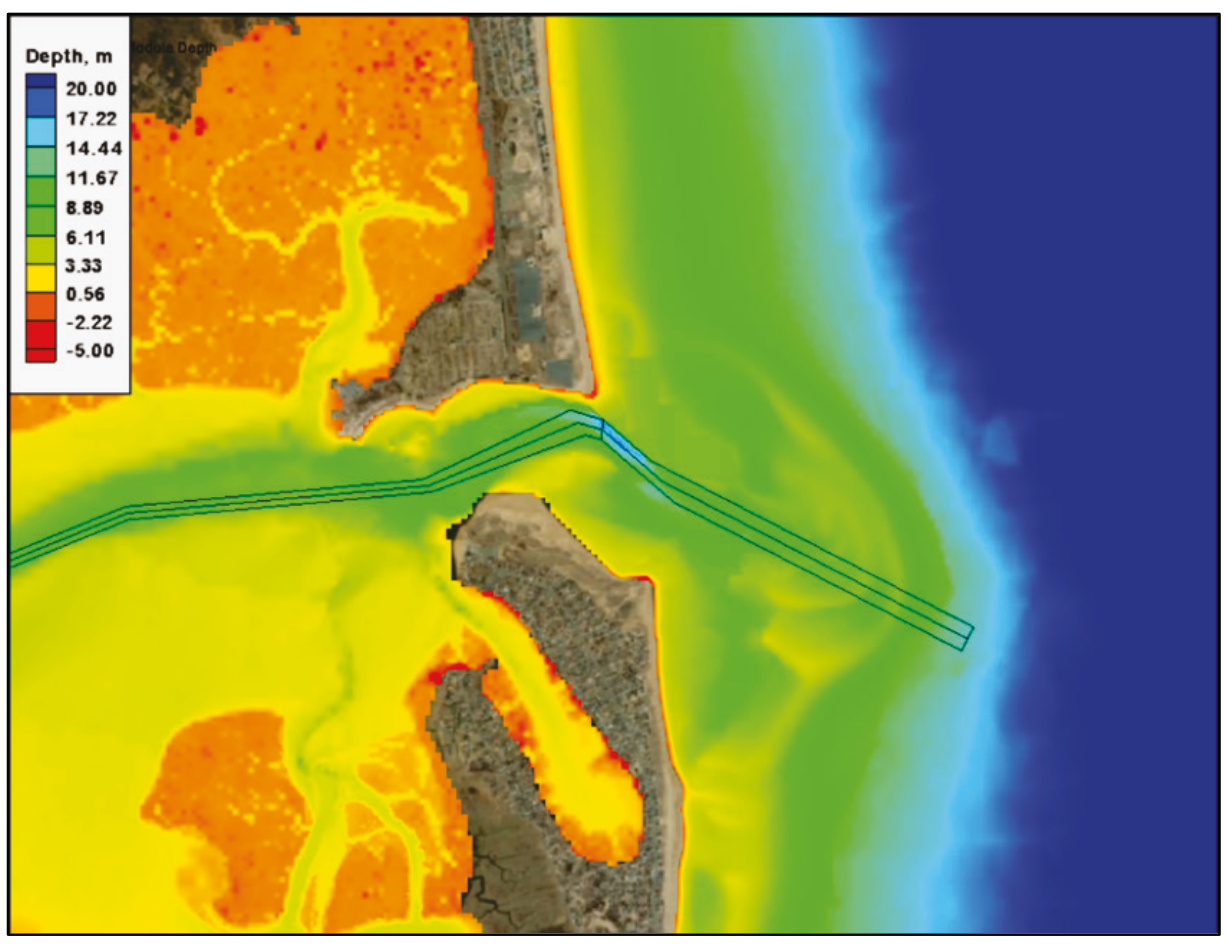




\section{Lengthen Jetties by $152 \mathrm{~m}$ (500 ft), Alternative 8}

A second structure modification involved lengthening both jetties by $152 \mathrm{~m}$ (500 ft) (Figure 30). Each jetty extension continued the same orientation as the existing outer jetty portion.

Figure 30. Alternative 8: Lengthen jetties.

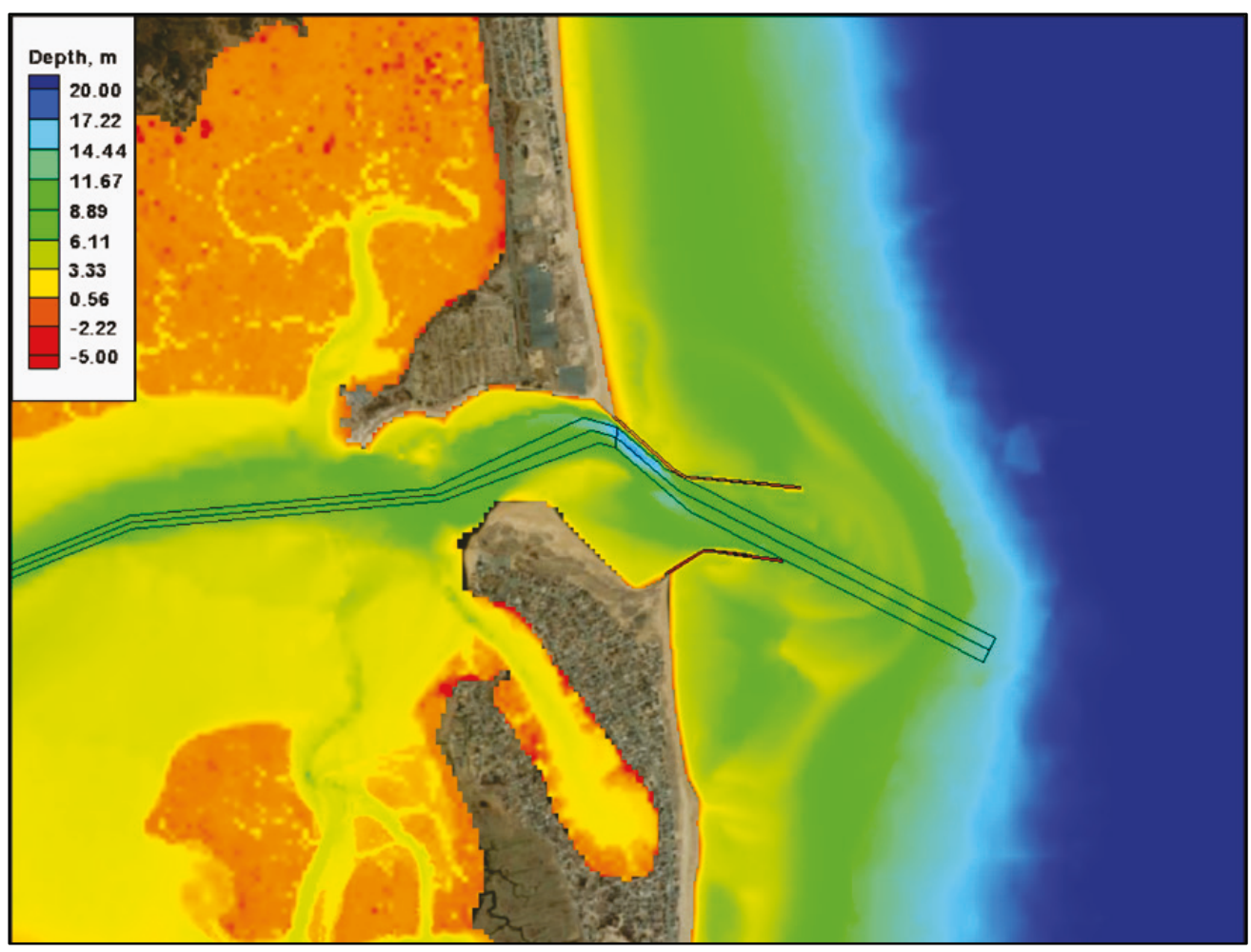

\section{$\underline{\text { Shorten Jetties, Alternative } 9}$}

In this structure alternative, the outer portion of each jetty was removed. For the North Jetty, this corresponds to approximately $384 \mathrm{~m}$ while approximately $198 \mathrm{~m}$ (650 ft) was removed from the South Jetty. Figure 31 shows the lengths of the jetties with the removal of the extensions. The length of the jetties in Figure 31 can be compared to the rehabbed length of the jetties shown in Figure 21. 
Figure 31. Alternative 9: Shorten jetties.

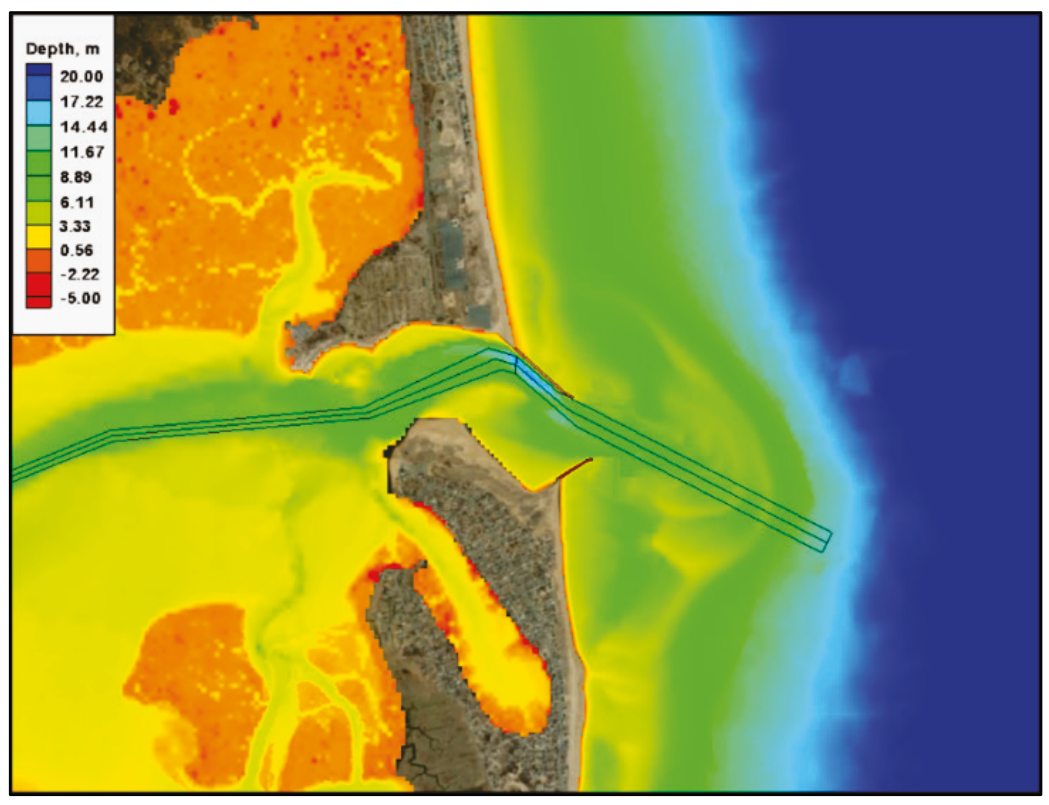

$\underline{\text { Reorient Jetties, Alternative } 10}$

In this alternative (Figure 32), the outer portion of each jetty was reoriented to match the alignment of the navigation channel. The same jetty length was kept compared to the existing jetties (Figure 21).

Figure 32. Alternative 10: Reoriented jetties.

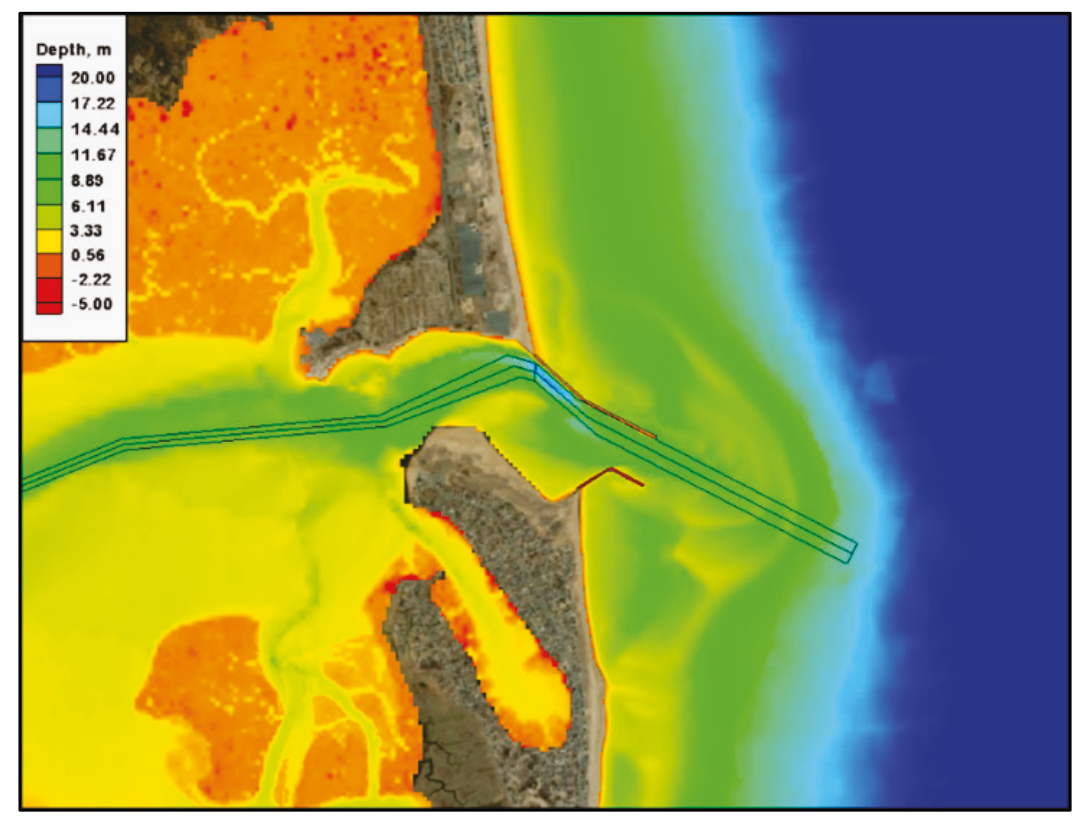




\section{Dogleg on North Jetty, Alternative 11}

In this alternative a $152 \mathrm{~m}$ (500 ft) length dogleg was added to the tip of the North Jetty, and the lengthened jetty was oriented towards the southeast (Figure 33).

Figure 33. Alternative 11: Add dogleg extension to North Jetty.

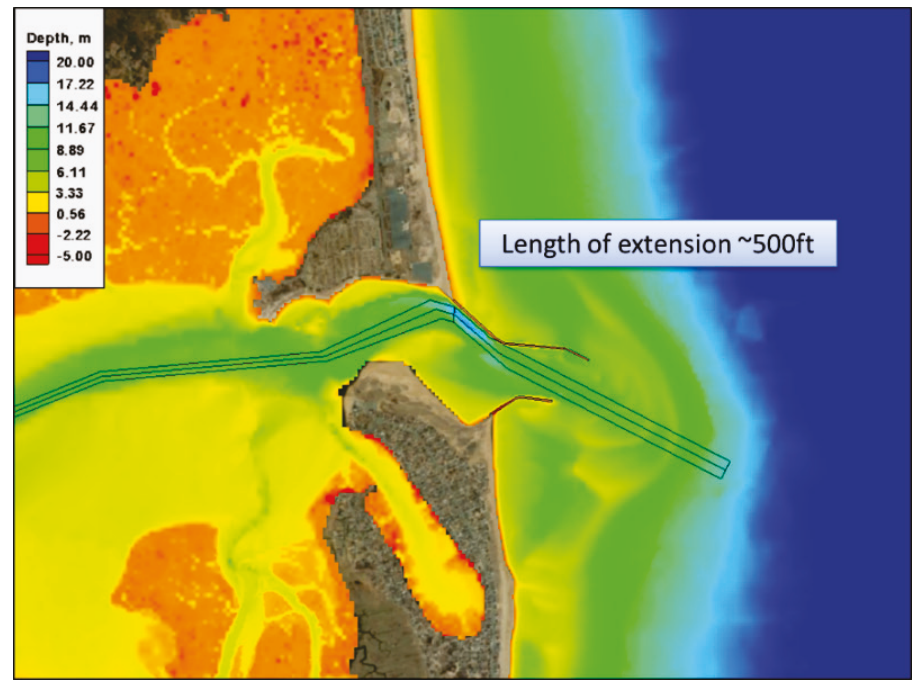

Doglegs on Jetties, Alternative 12

Doglegs were added to both of the jetties in Alternative 12. The jetty extensions were approximately $152 \mathrm{~m}(500 \mathrm{ft})$ in length and oriented towards the southeast. The configuration of the jetties with doglegs is shown in Figure 34.

Figure 34. Alternative 12: Doglegs on jetties.

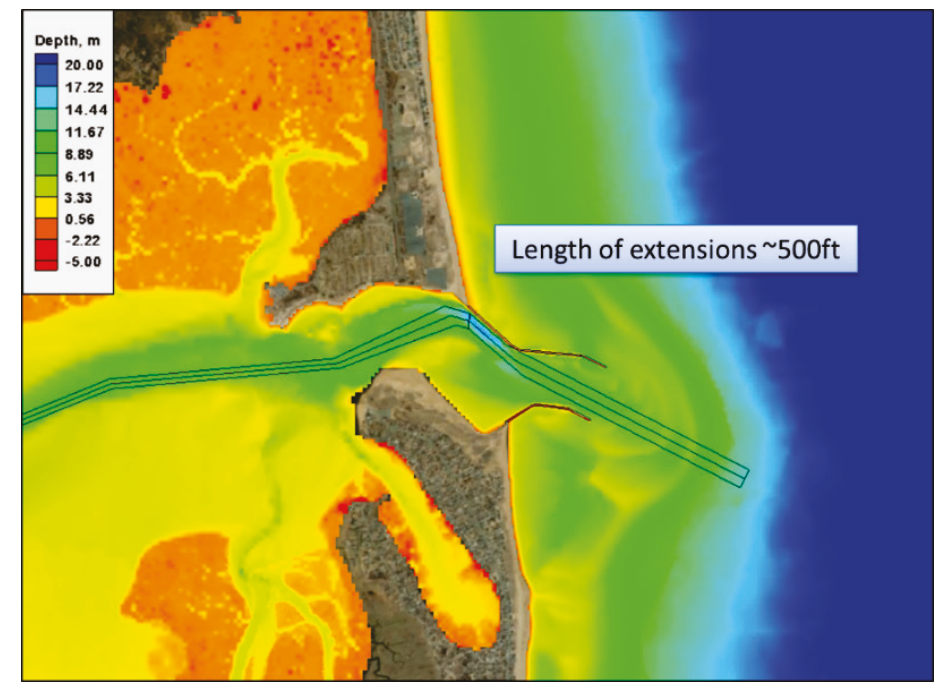


Spurs Inside and Outside Jetties, Alternatives 13 and 14

The purpose of these two alternatives was to investigate the effects of adding spurs inside and outside jetties (Figure 35).

Figure 35. Alternative 13: Add spur inside North Jetty.

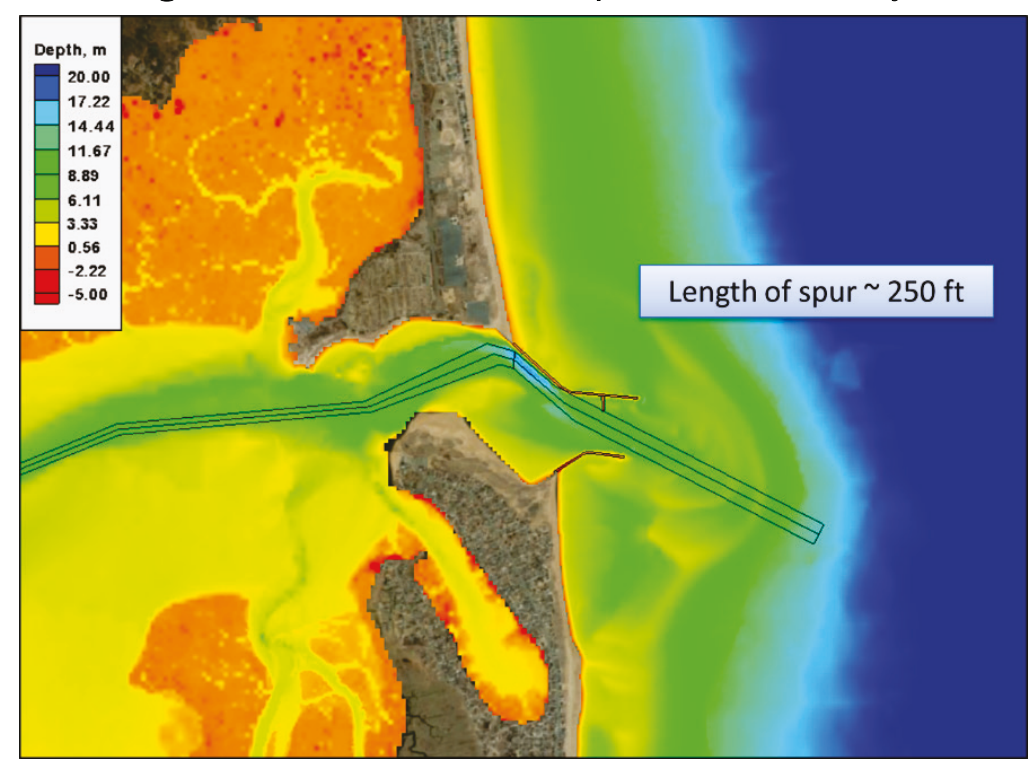

Figure 35 and Figure 36 show the design of a $76 \mathrm{~m}$ spur on the North and South Jetty, respectively. The north spur is oriented towards the channel to train the flow towards the south, and the south spur is oriented towards the downdrift beach to minimize sand transport back into the navigation channel.

Figure 36. Alternative 14: Add spur outside South Jetty.

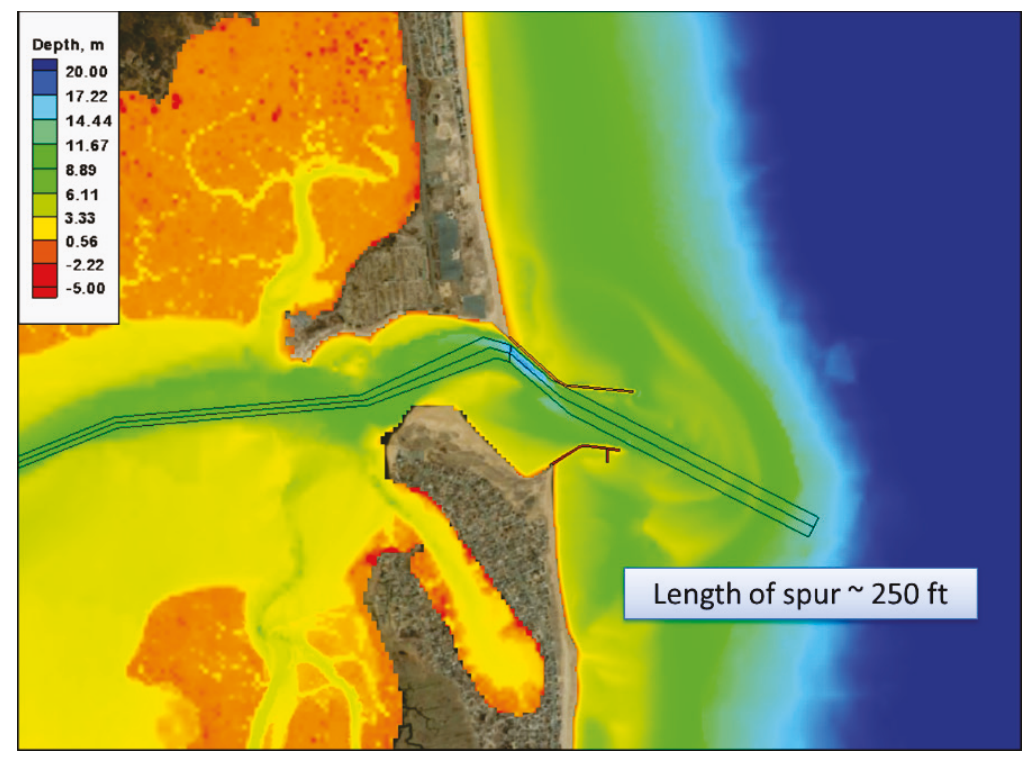




\section{Detached Breakwaters Offshore of Plum Island, Alternative 15}

The final structural alternative consists of four detached breakwaters located offshore of Plum Island, south of the South Jetty. Each 144 m (472 ft) long breakwater is located approximately $366 \mathrm{~m}$ (1200 ft) offshore. The gap width between the breakwaters is approximately $72 \mathrm{~m}(236 \mathrm{ft})$. Figure 37 shows the layout of the breakwaters.

Figure 37. Alternative 15: Addition of four breakwaters.

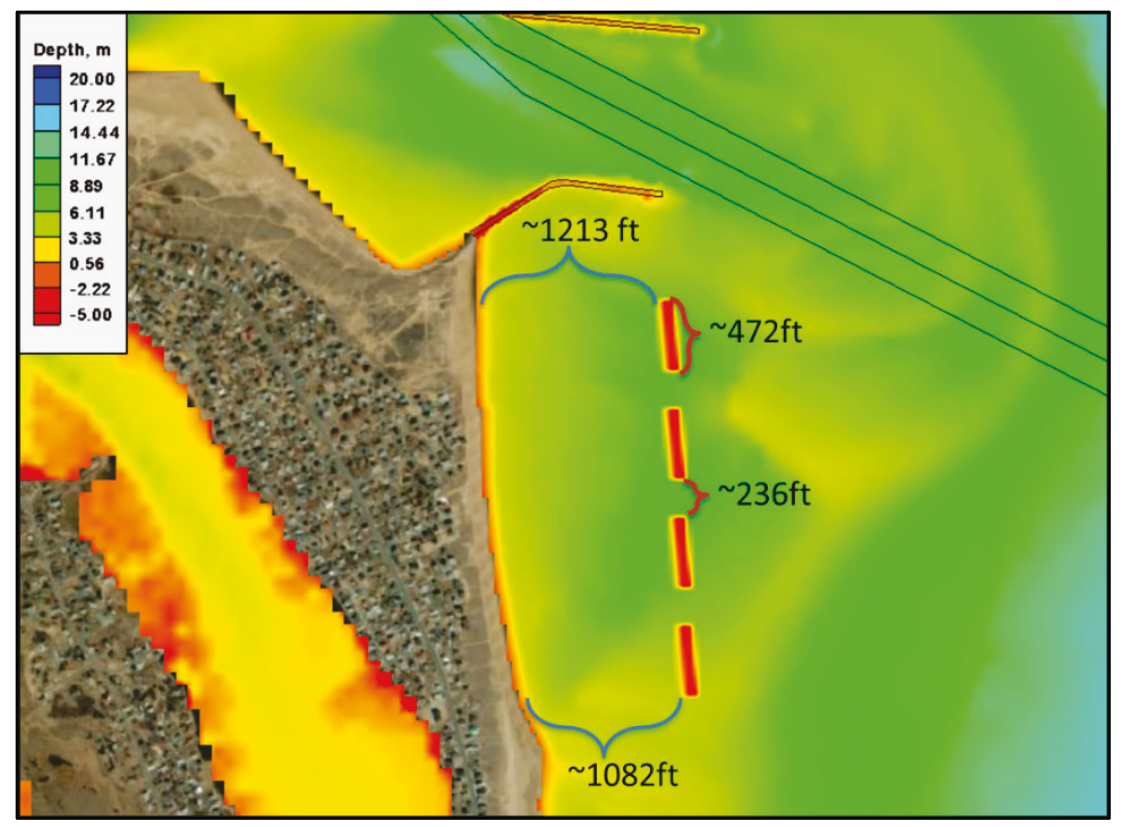

\subsubsection{Phase I, select alternatives: 6-month simulations.}

In the Phase I study, the final group contained 6 alternatives that are a subset of the 15 original alternatives with the most favorable results on reducing beach erosion and inlet shoaling. Two of the alternatives in this group were identical to the original, and four were modified from the original and bear the same alternative number with a letter added to clarify that they are further modified. This group of alternatives was run for a 6-month period spanning winter and spring conditions (January to June 2011) (Table 2-4). 
Table 2-4. Summary of 6-month alternative simulations for Phase I.

\begin{tabular}{|c|c|c|}
\hline Alternative & Description & Notes \\
\hline 2 & $\begin{array}{l}\text { Mine flood delta up to } 382 \mathrm{~K} \mathrm{~m}^{3} \\
(500 \mathrm{~K} \text { cu yd) }\end{array}$ & No modifications \\
\hline $3 b$ & $\begin{array}{l}\text { Mine North Point, Plum Island up to } \\
382 \mathrm{~K} \mathrm{~m}^{3}(500 \mathrm{~K} \text { cu yd) }\end{array}$ & Only subaerial mining of north spit \\
\hline $6 b$ & $\begin{array}{l}\text { Construct sedimentation basin inside } \\
\text { South Jetty with capacity } 229 \mathrm{~K} \mathrm{m^{3 }} \\
\text { (300K cu yd) }\end{array}$ & $\begin{array}{l}\text { Basin moved slightly further north to minimize } \\
\text { adverse South Jetty impacts }\end{array}$ \\
\hline 9 & Remove outer portion of jetties & No modifications \\
\hline $15 b$ & $\begin{array}{l}\text { Add detached breakwaters offshore of } \\
\text { Plum Island }\end{array}$ & $\begin{array}{l}8 \text { total breakwaters ( } 4 \text { added to the south of } \\
\text { initial structures) }\end{array}$ \\
\hline $15 c$ & $\begin{array}{l}\text { Add detached breakwaters offshore of } \\
\text { Plum Island }\end{array}$ & $\begin{array}{l}8 \text { total breakwaters ( } 4 \text { added to the south of } \\
\text { initial structures), Combine mine and } \\
\text { placement from Alt } 6 \mathrm{~b}\end{array}$ \\
\hline
\end{tabular}

\section{Flood Delta Mining (6 months), Alternative 2}

This alternative was chosen for a 6-month simulation period, and no modification to the design was implemented. Figure 38 shows the location of the mined flood shoal and the three placement locations.

Figure 38. Alternative 2: 6-month flood delta mining and placement.

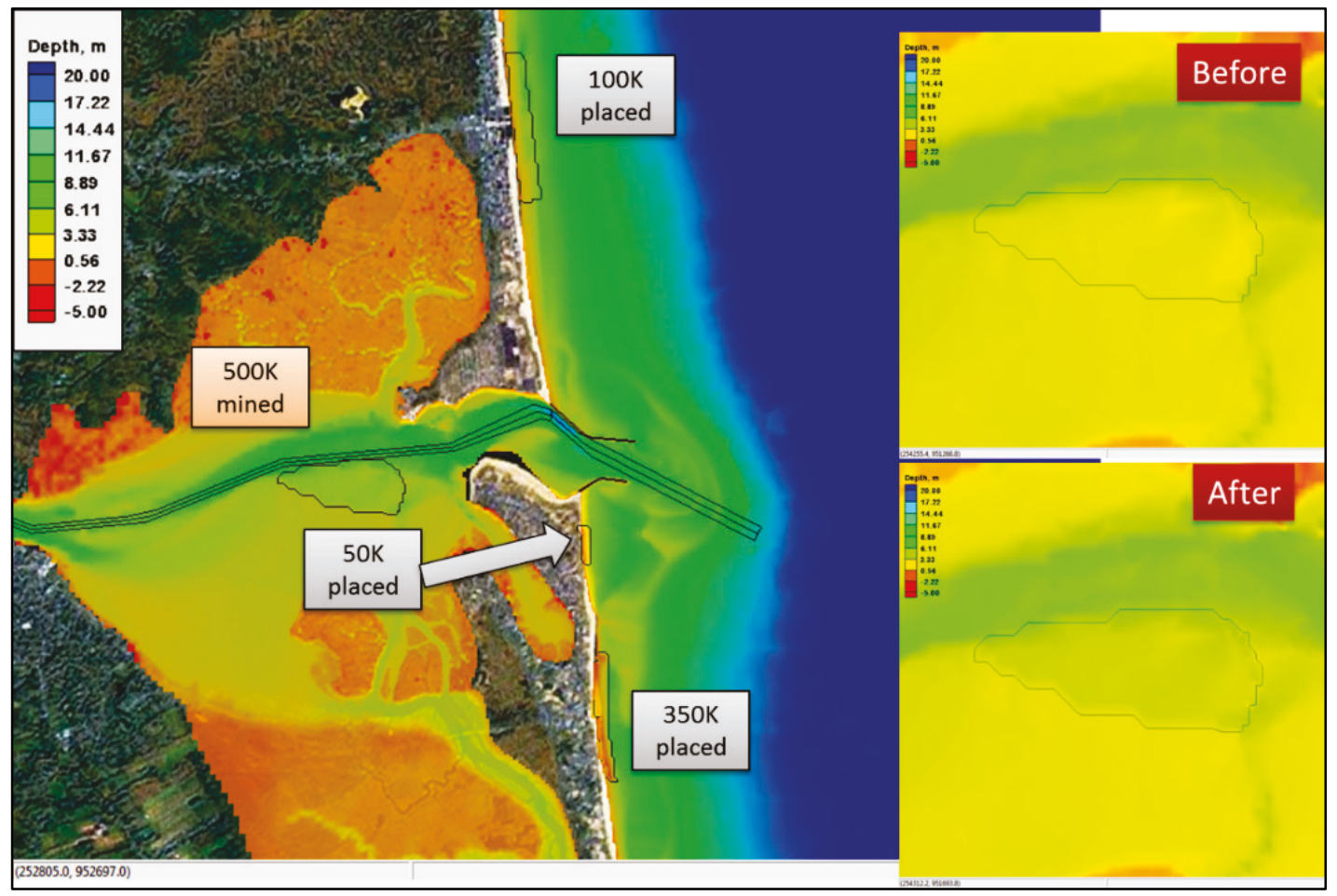


Modified North Point, Plum Island Mining (6 months), Alternative $3 \mathrm{~b}$

Alternative $3 \mathrm{~b}$ shown in Figure 39 contains a slight modification to the mining zone as compared to the original Alternative 3 (Figure 25). For this alternative, only the subaerial portion has been mined. As a result, $286,708 \mathrm{~m}^{3}$ (375,000 cu yd) of material has been mined, to be distributed in the placement areas as follows: 76,455 $\mathrm{m}^{3}$ (100,000 cu yd) offshore of Salisbury Beach; 38,278 m³ (50,000 cu yd) offshore of PIBN1; and $172,025 \mathrm{~m}^{3}$ (225,000 cu yd) offshore of PIBN2, respectively.

Figure 39. Alternative 3b: 6-month simulation of modified North Point mining and placement.

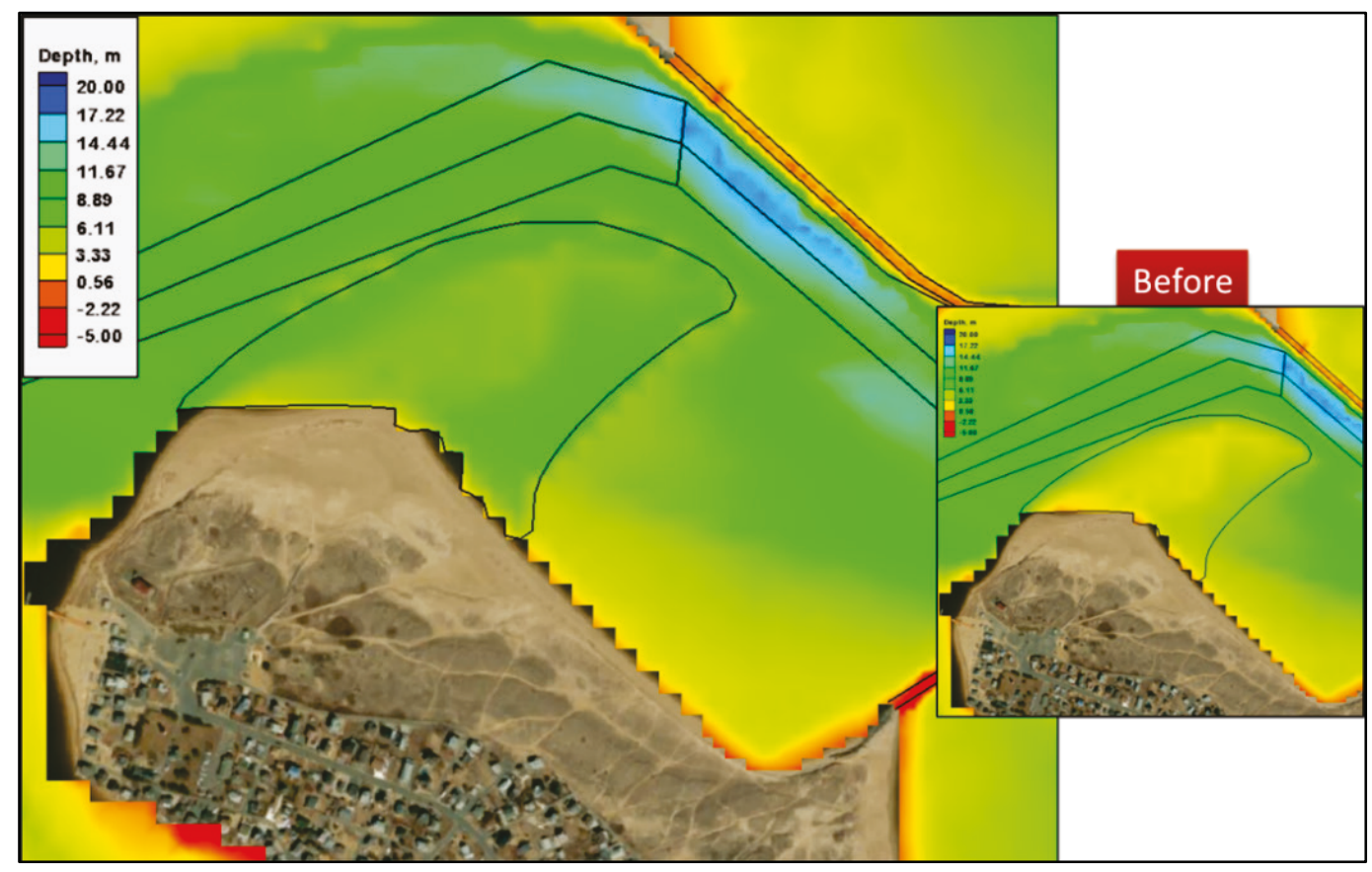

Modified Sedimentation Basin (6 months), Alternative 6b

This alternative has been slightly modified from its predecessor, Alternative 6 . The sedimentation basin was moved northwest, slightly farther away from the South Jetty. The basin was dredged to $7.75 \mathrm{~m}$ (25.4 ft) below MSL and has a capacity of $\sim 235,483 \mathrm{~m}^{3}$ (308,000 cu yd). The present (modified) and former designs of the basin are shown in Figure 40. 
Figure 40. Alternative $6 \mathrm{~b}$ : 6 -month simulation of modified sedimentation basin (in this figure, $\mathrm{CY}=$ cubic yards).

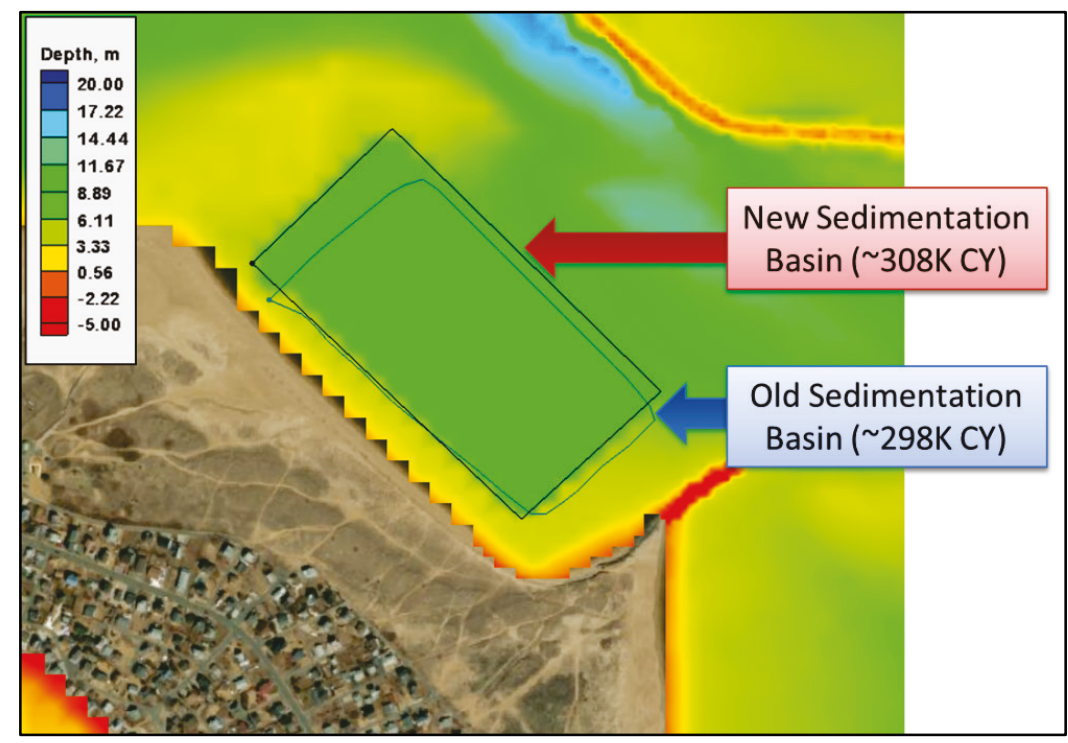

\section{Shorten Jetties (6 months), Alternative 9}

There were no modifications for the 6-month simulation of Alternative 9. In this structure alternative, the outer portion of each jetty was removed. For the North Jetty, this corresponds to approximately $384 \mathrm{~m}(1,260 \mathrm{ft})$ while approximately $198 \mathrm{~m}$ (650 ft) was removed from the South Jetty. Figure 41 shows the shortened jetties.

Figure 41. Alternative 9: 6-month simulation of shortened jetties.

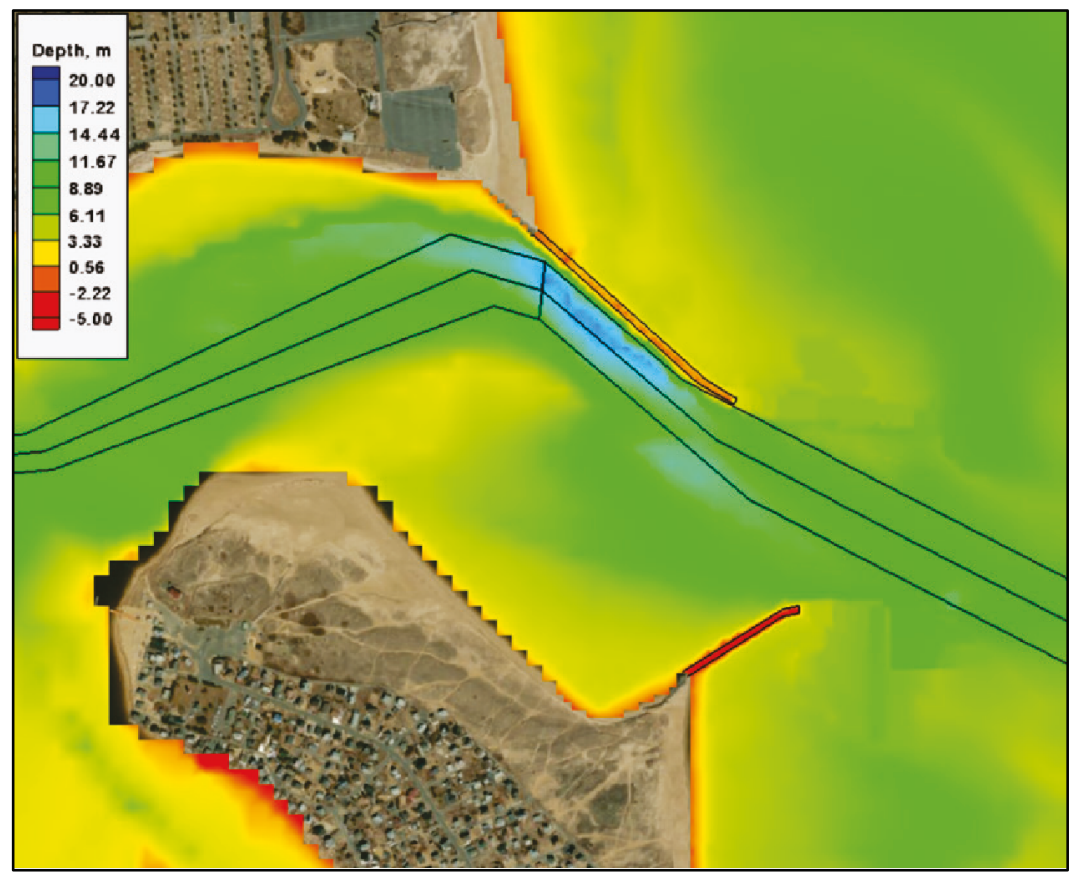




\section{Expanded Detached Breakwaters (6 months), Alternative 15b}

Alternative $15 \mathrm{~b}$ consists of the original four detached breakwaters from Alternative 15 located offshore of Plum Island and an additional set of four breakwaters extending the total breakwater protection area toward the

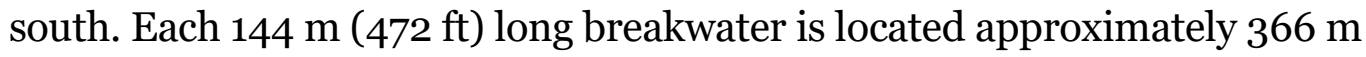
$(1,200 \mathrm{ft})$ offshore. The gap width between the breakwaters is approximately $72 \mathrm{~m}$ ( $236 \mathrm{ft}$ ). Figure 42 shows the layout of the breakwaters.

Figure 42. Alternative 15b: 6-month simulation of eight total breakwaters.

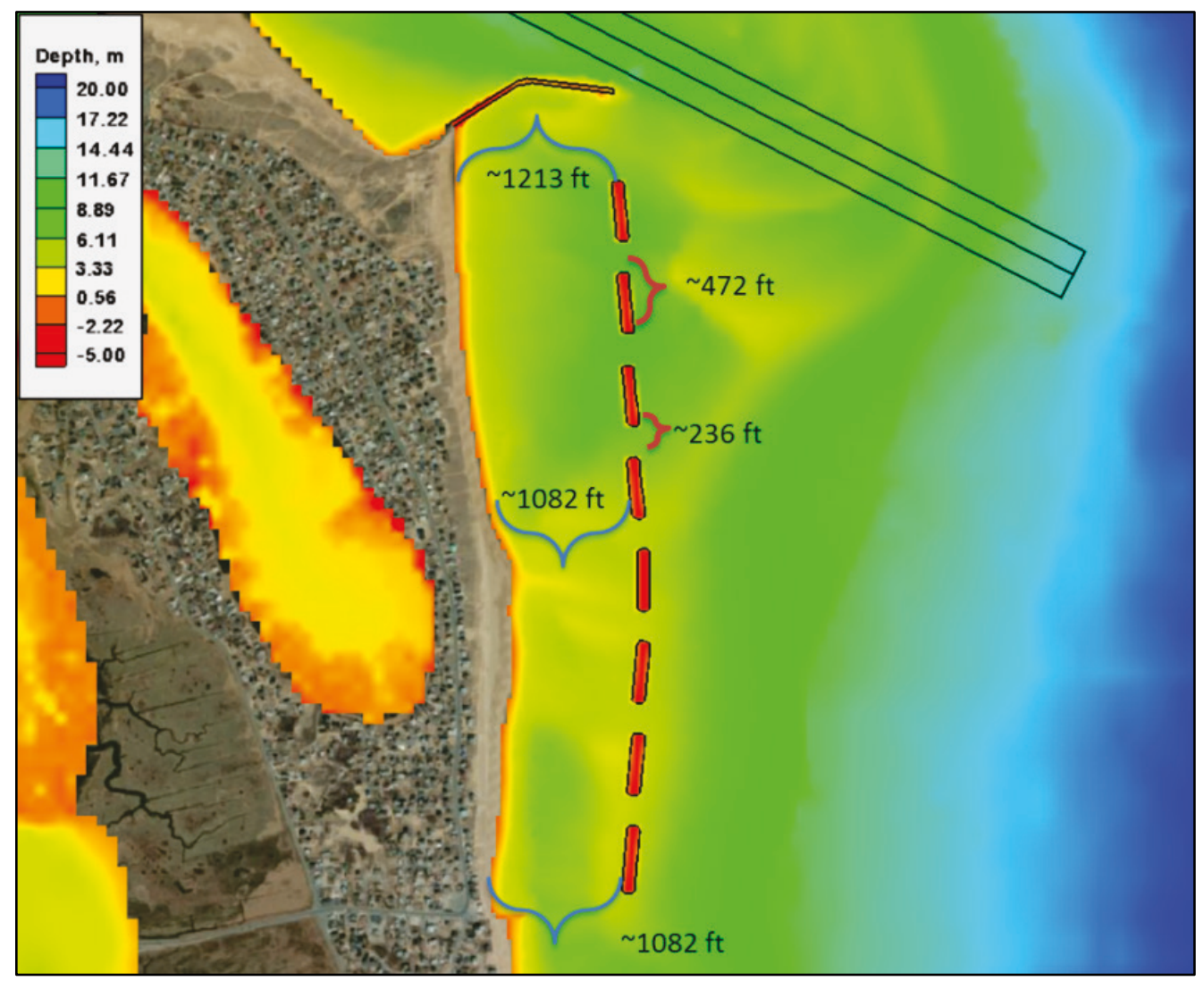


Expanded Detached Breakwaters and Modified Sedimentation Basin Mining (6 months), Alternative $15 \mathrm{c}$

Alternative $15 \mathrm{c}$ duplicates the structure setup from Alternative $15 \mathrm{~b}$ and adds the sedimentation basin mining component from Alternative $6 \mathrm{~b}$. Figure 43 shows the layout of the breakwaters.

Figure 43. Alternative 15c: 6-month simulation of eight total breakwaters and sedimentation basin mining and normal placement of material.

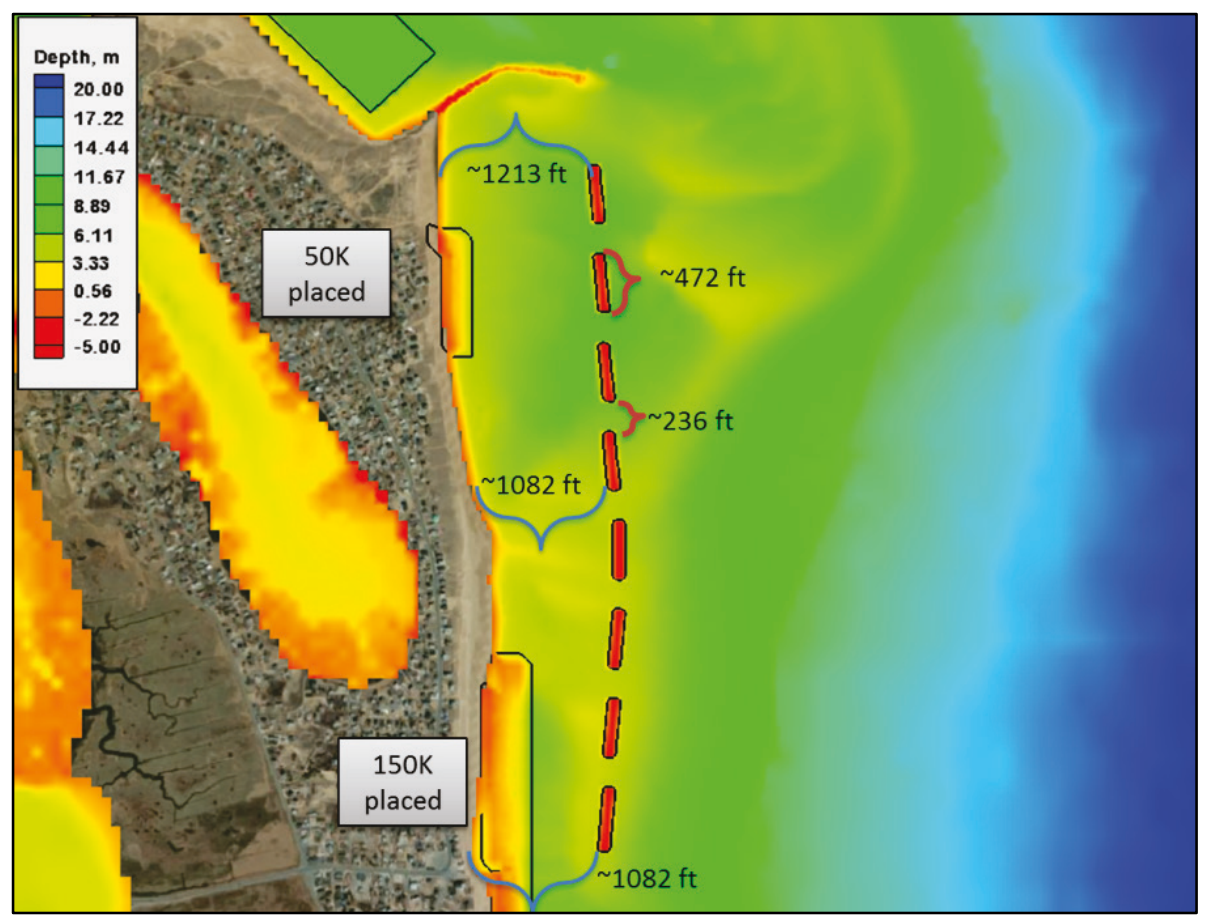

\subsubsection{Phase II}

\subsubsection{Existing condition}

The South Jetty of Merrimack Inlet was fully rehabilitated in April 2014, and two lidar surveys were completed in December 2014 and May 2015. The Phase II study uses the latest lidar topographic and bathymetric datasets to develop a new existing condition for the CMS. Bathymetry is updated, and the fully rehabilitated South Jetty is incorporated in the model grid.

Using the new existing condition, the CMS validation in sediment transport calculations was conducted, and the results were analyzed. Following agreement of the sediment transport pathways and general morphologic trends over the 6-month time frame, from 15 December 2014 to 15 June 2015, the Phase II existing condition was applied to selected alternatives to 
evaluate structural and sediment management strategies. Results of the Phase II alternatives were compared with those under the new existing condition to illustrate relative changes in morphologic response.

\subsubsection{Selected 6-month Alternatives}

Figure 44 shows the lidar observed morphology change between 15 December 2014 and 27 May 2015. The two lidar surveys reveal that severe shoreline erosion occurred on the northern tip of Plum Island within Merrimack Inlet. Additionally, nearshore erosion and offshore bar formation is evident downdrift of the rehabilitated South Jetty in front of Plum Island Beach. The impact of sediment placement on these features became a primary concern in the Phase II study.

Figure 44. Observed morphology change between 15 December 2014 and 27 May 2015. The coastal outline is the MSL contour. The warm color represents the deposition, and the cold color represents the erosion.

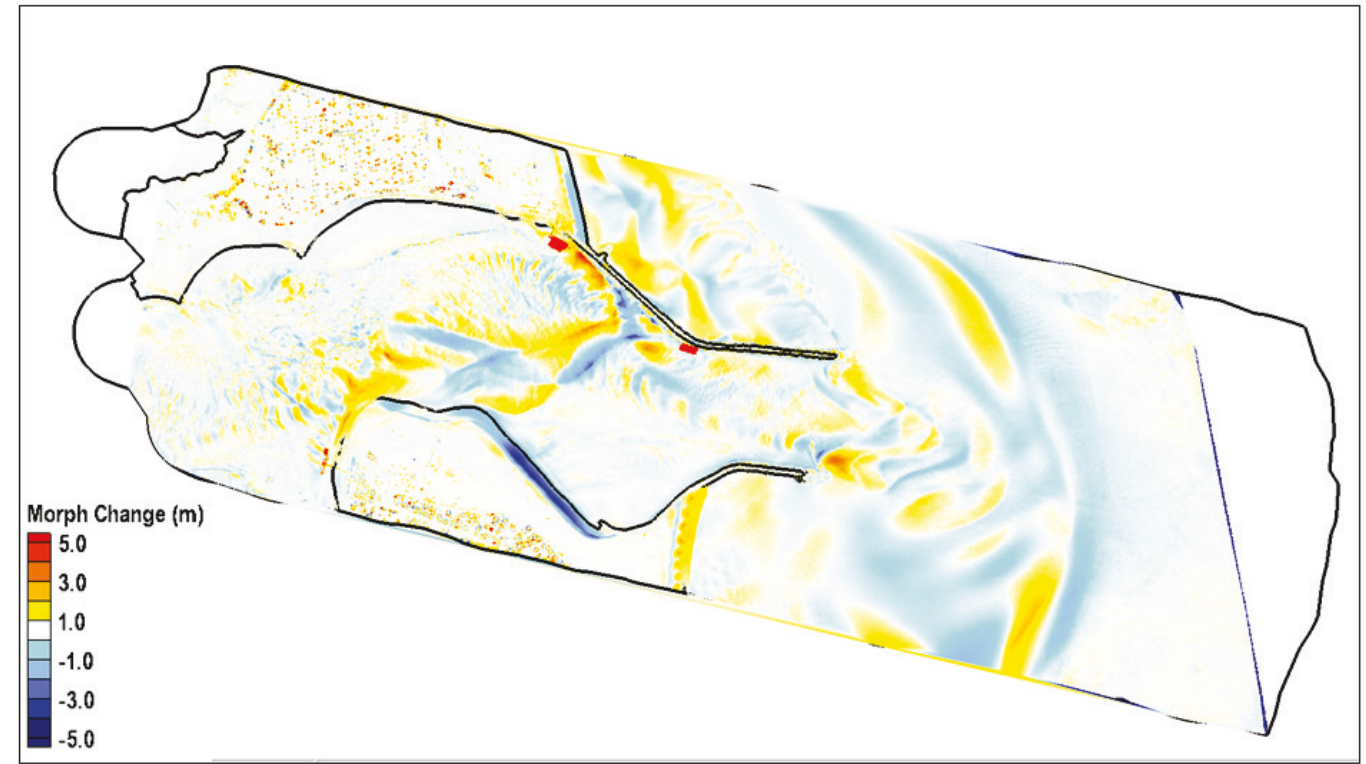

Nine alternatives were developed and evaluated to investigate the relative effects of sediment management strategies on local sediment transport with the fully rehabilitated jetty condition. Focusing on Merrimack Inlet and Plum Island area, four alternatives are original alternatives specified in the Phase I study, three are modified alternatives based on the original, and two are new additions. 


\section{$\underline{\text { Ebb Delta Mining, Alternative } 1}$}

This is an unmodified alternative from the Phase I study, in which $382,277 \mathrm{~m}^{3}$ (500,000 cu yd) of material was removed from the southern portion of the ebb tidal delta (Figure 45). The sand was placed in three separate locations in the nearshore, approximately $76,455 \mathrm{~m}^{3}$ (100,000 cu yd) offshore of Salisbury Beach, 38,228 m³ (50,000 cu yd) offshore of PIBN1, and 267,594 m33 (350,000 cu yd) offshore of PIBN2, respectively.

Figure 45. Alternative 1: Phase II 6-month simulation of flood delta mining and placement (in this figure, $\mathrm{CY}=$ cubic yards).

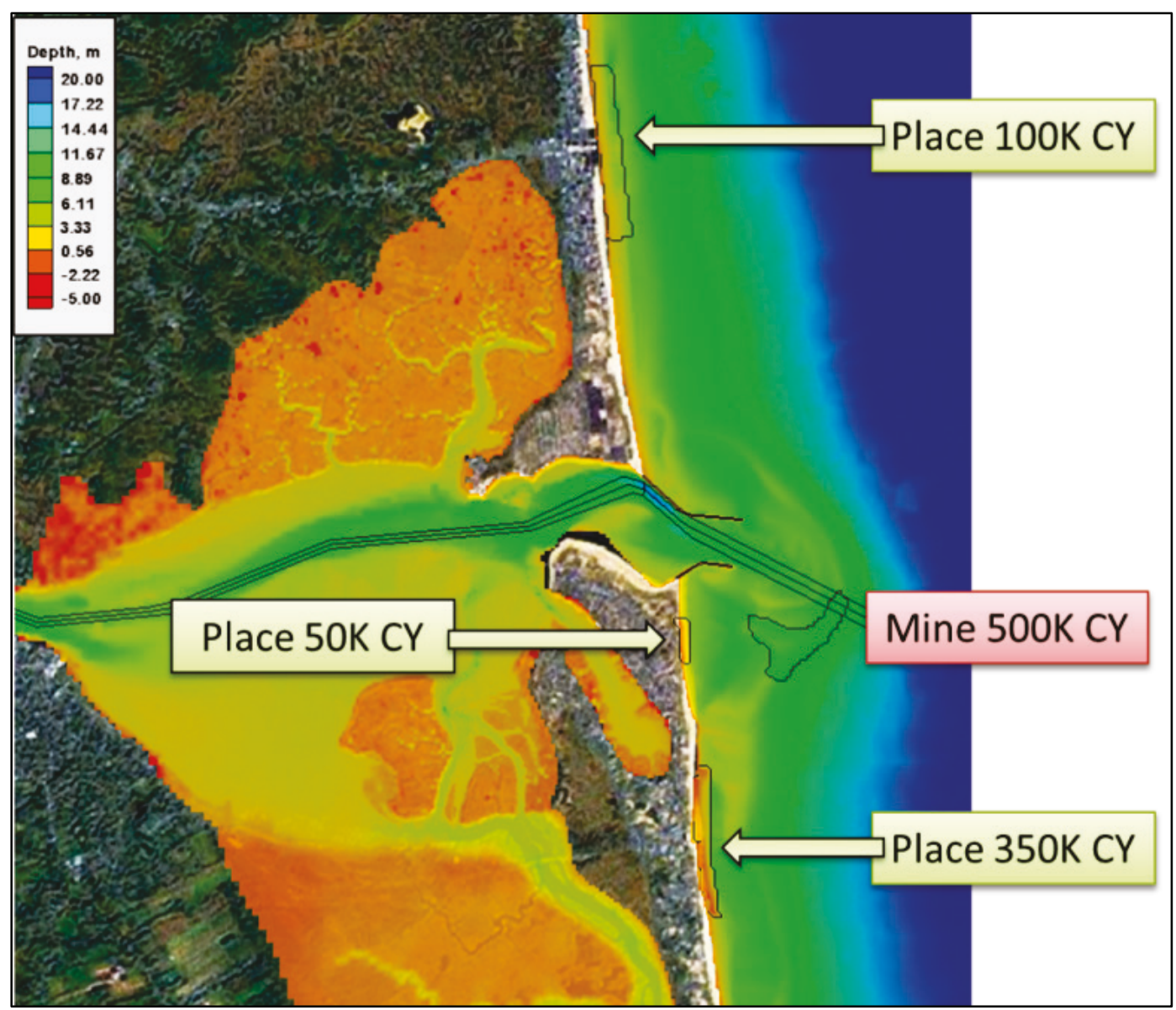




\section{Flood Delta Mining, Alternative 2}

This alternative was designed to mine up to $382,277 \mathrm{~m}^{3}$ ( $500,000 \mathrm{cu} \mathrm{yd}$ ) of sediment from these shoals. Figure 46 shows the location of the mined flood shoal and the three placement locations. The volumes placed are the same as for the ebb delta mining alternative.

Figure 46. Phase II 6-month simulation of flood delta mining and placement, Alternative 2 (in this figure, $\mathrm{CY}=$ cubic yards).

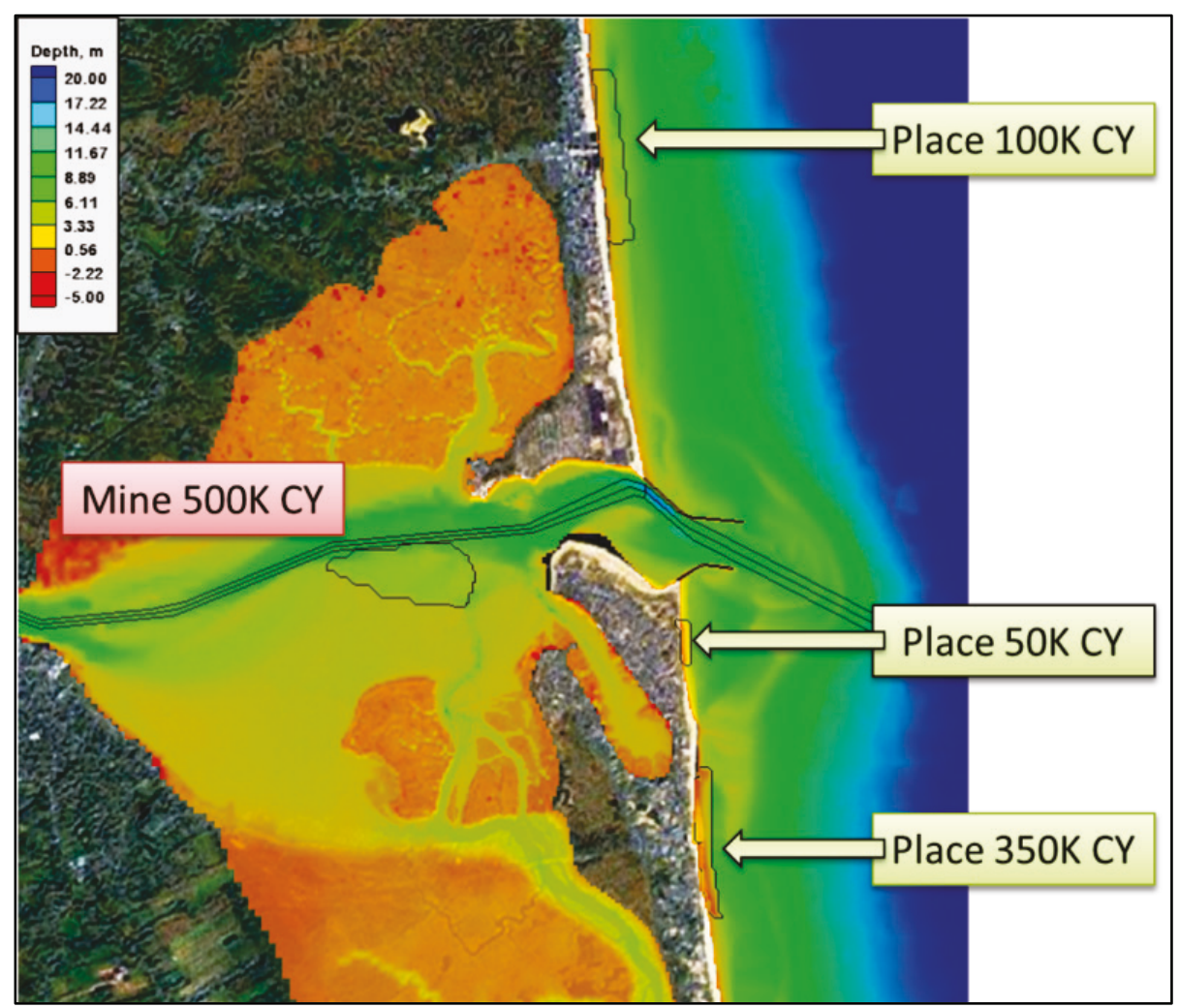

Modified North Point, Plum Island Mining, Alternative 3c

Alternative 3c (shown in Figure 47) contains another slight modification to the mining zone as compared to Alternative 3 (Figure 25) and Alternative $3 \mathrm{~b}$ from Phase I study due to the change in underlying bathymetry changes observed in lidar from 2014. The shape of the mining area better represents the spit feature available for mining. Approximately 286,708 $\mathrm{m}^{3}$ (375,000 cu yd) of material has been mined, to be distributed in the placement areas as follows: $76,455 \mathrm{~m}^{3}$ (100,000 cu yd) offshore of Salisbury Beach; 38,278 m³ (50,000 cu yd) offshore of PIBN1; and 172,025 m³ (225,000 cu yd) offshore of PIBN2, respectively. 
Figure 47. Alternative 3c: Phase II 6-month simulation of modified North Point mining and placement areas.

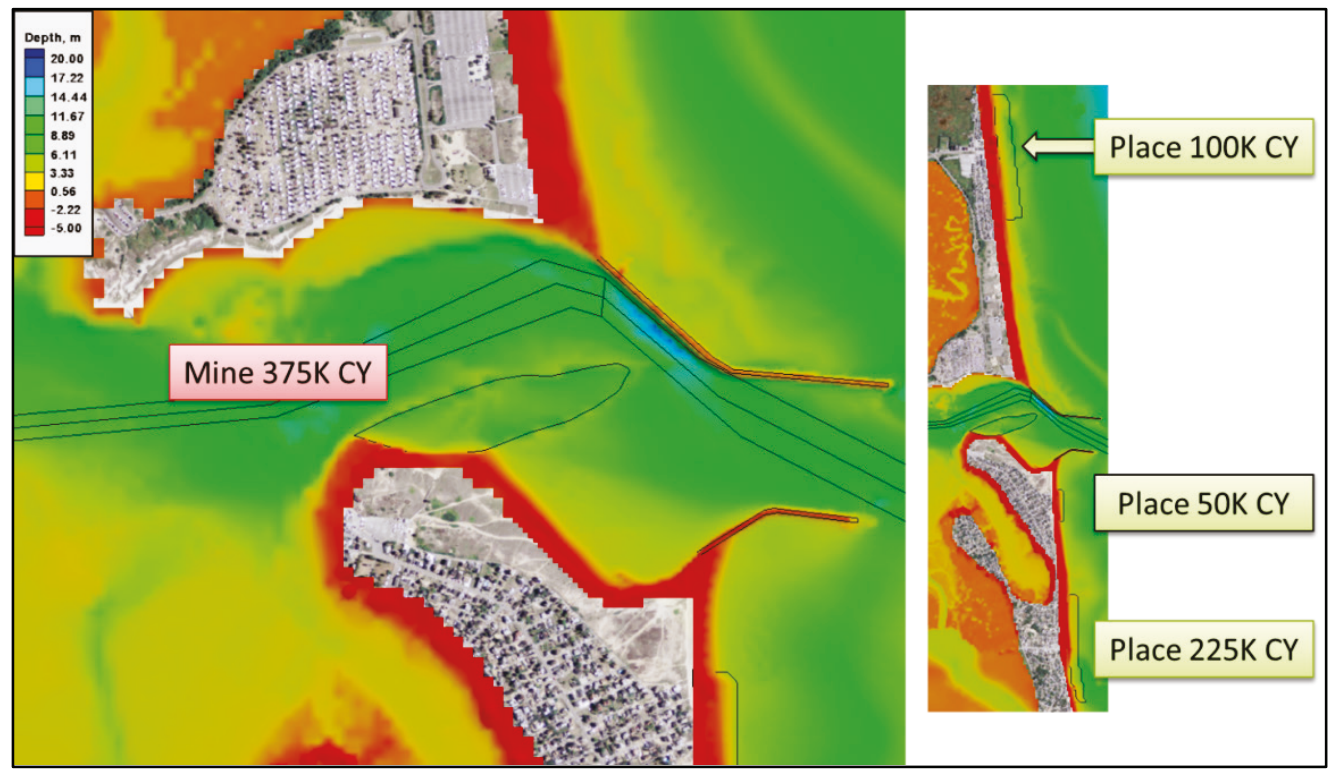

$\underline{\text { Shortened Jetties, Alternative } 9}$

There were no modifications for the 6-month simulation of Alternative 9. In this structure alternative, the outer portion of each jetty was removed. For the North Jetty, this corresponds to approximately $384 \mathrm{~m}$ (1,260 ft) while approximately $198 \mathrm{~m}$ (650 ft) was removed from the South Jetty. Figure 48 shows the lengths of the jetties with the removal of the extensions.

Figure 48. Alternative 9: Phase II 6-month simulation of shortened jetties.

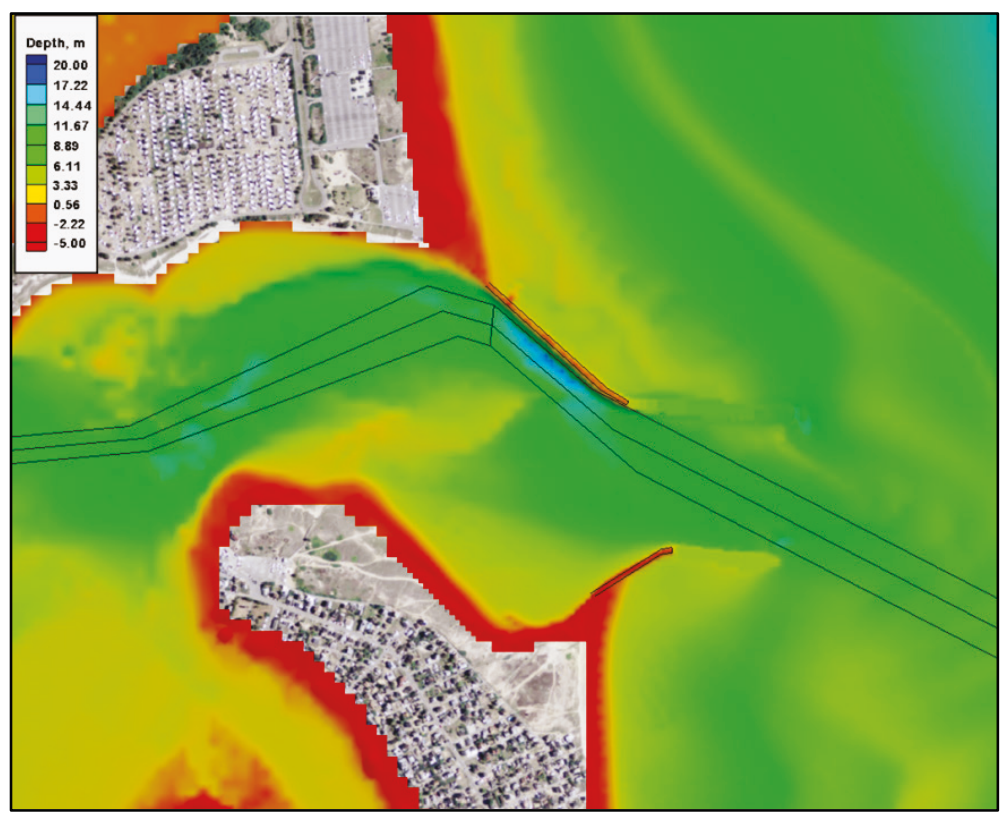




\section{Expanded Detached Breakwaters, Alternative 15b}

Alternative 15b in Phase II (shown in Figure 49) is unmodified from its counterpart in Phase I of this study. This alternative consists of eight detached breakwaters located offshore of Plum Island. Each $144 \mathrm{~m}$ (472 ft) long breakwater is located approximately $366 \mathrm{~m}(1,200 \mathrm{ft})$ offshore. The gap width between the breakwaters is approximately $72 \mathrm{~m}(236 \mathrm{ft})$.

Figure 49. Alternative 15b: Phase II 6-month simulation of eight breakwaters.

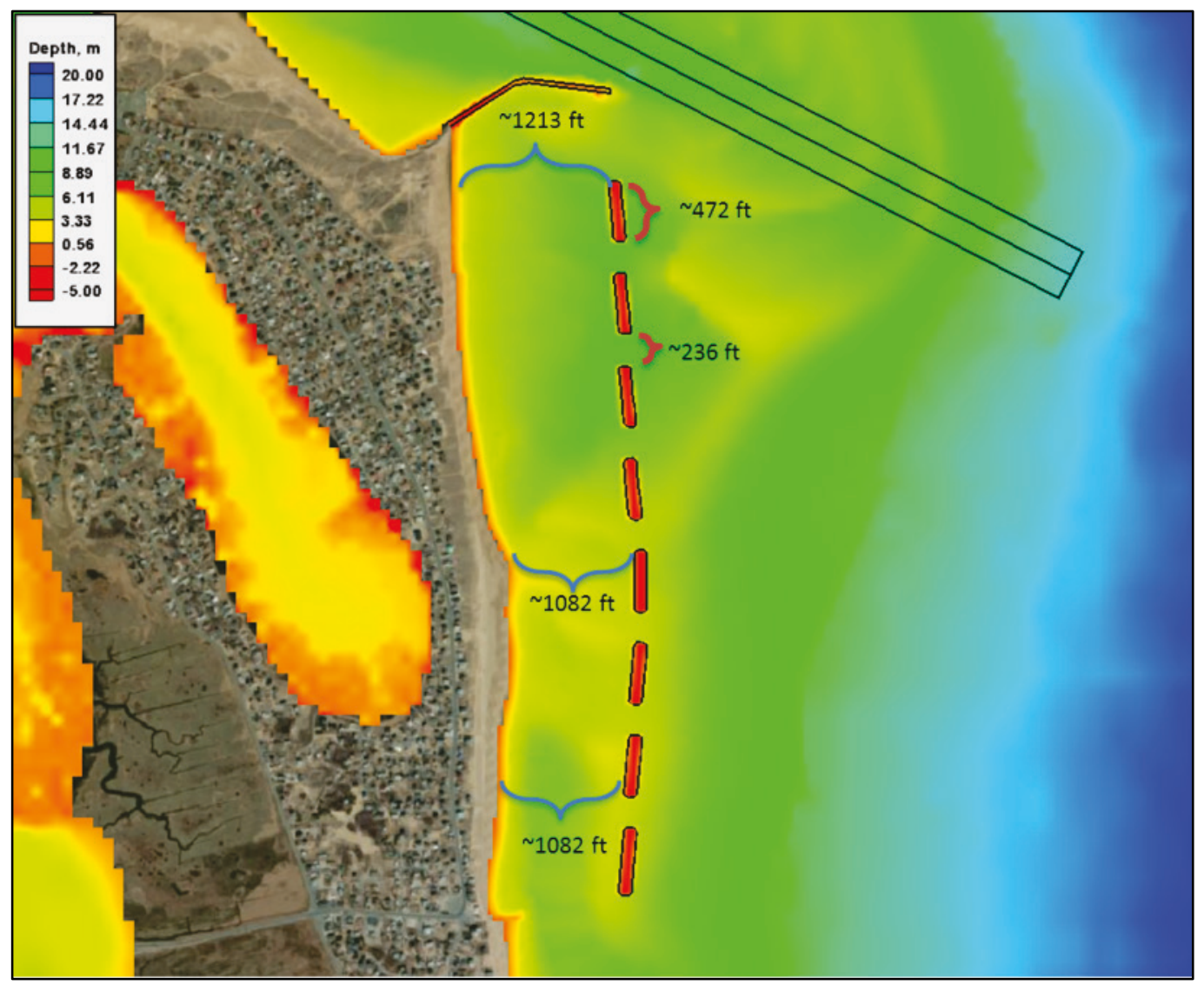


Expanded Detached Breakwaters and Ebb Shoal Mining, Alternative 15d

Alternative 15d combines the same structure setup for Alternative 15b with the ebb delta mining and placement scenario from Alternative 1 . The resulting breakwater structures and mining area are shown in Figure 50.

Figure 50. Alternative 15d: Phase II 6-month simulation of expanded breakwaters and ebb delta mining and placement.

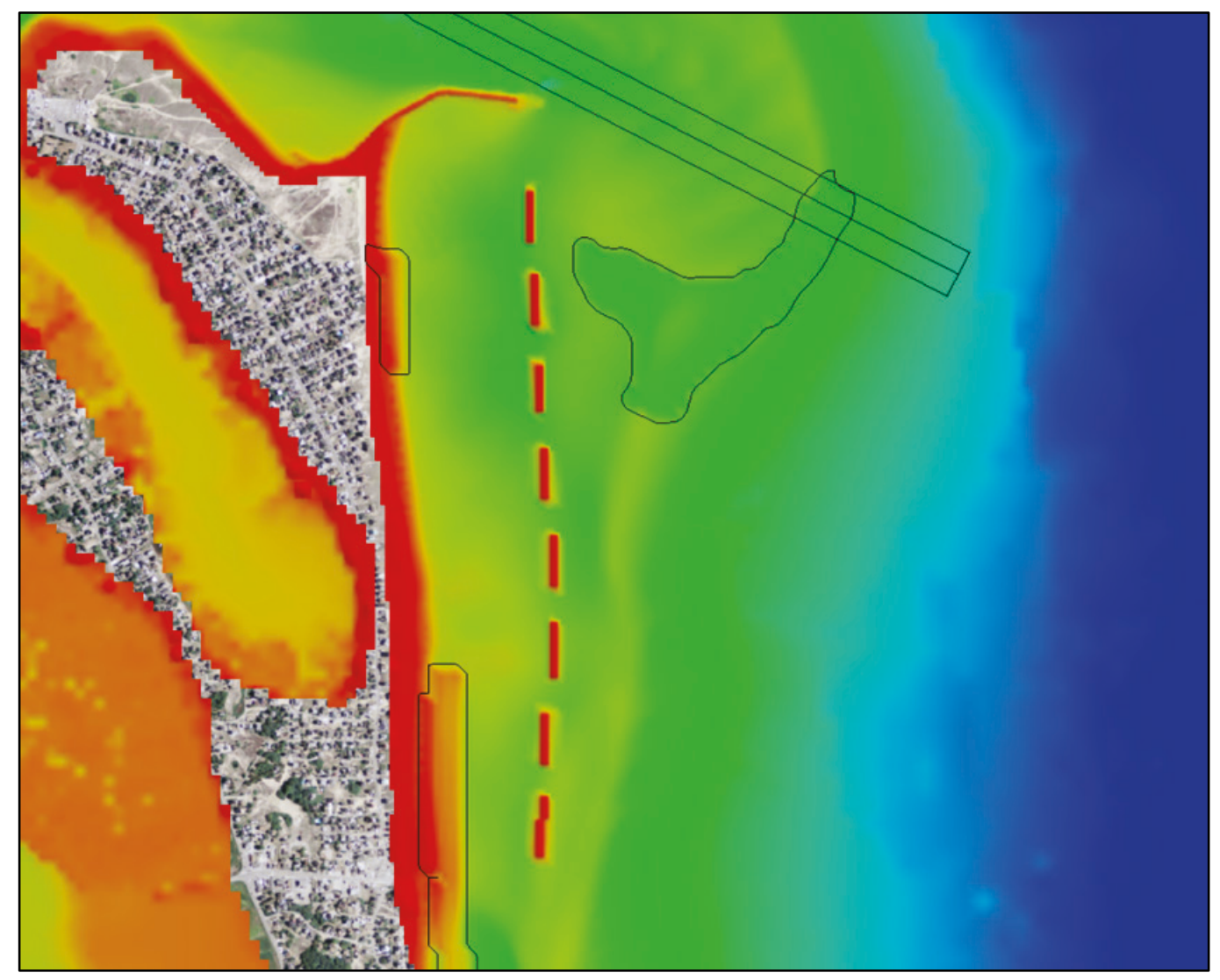

Shifted Expanded Detached Breakwaters, Alternative 15e

In Phase II, an additional breakwater alternative was chosen to be evaluated. In this alternative, the northern four breakwaters from Alternative 15b were removed, and four new breakwaters were added south of the remaining breakwaters. This results in a total of eight breakwaters; however, the footprint of the breakwaters is shifted farther to the south by approximately $863 \mathrm{~m}(2,832 \mathrm{ft})$. The designs of Alternatives 15b and 15e are compared in Figure 51. 
Figure 51. Alternative 15e: Phase II 6-month simulation of shifted expanded breakwaters. The image on the right depicts the shift of the eight breakwaters toward the south.

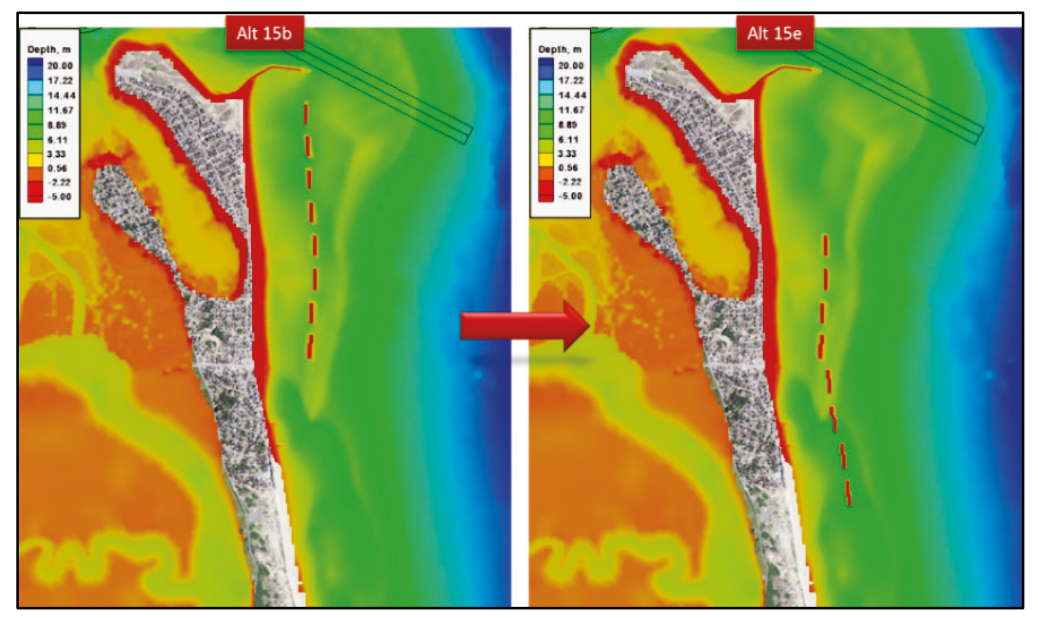

\section{$\underline{\text { Ebb Delta and North Spit Mining, Alternative } 16}$}

This alternative (shown in Figure 52) combines mining 229,366 m³ (300,000 cu yd) from a modified version of the ebb delta mining area from Alternative 1 and the north spit mining area from Alternative $3 \mathrm{c}$. The sand was placed in four separate locations in the nearshore, approximately $76,455 \mathrm{~m}^{3}$ (100,000 cu yd) offshore of Salisbury Beach; 76,455 m³ (100,000 cu yd) offshore of PIBN1; 286,708 m³ (375,000 cu yd) offshore of PIBN2; and 19,114 m³ (25,000 cu yd) offshore between North Point and the South Jetty, respectively.

Figure 52. Alternative 16: Ebb delta and north spit mining with modified placement areas (in this figure, $\mathrm{CY}=$ cubic yards).

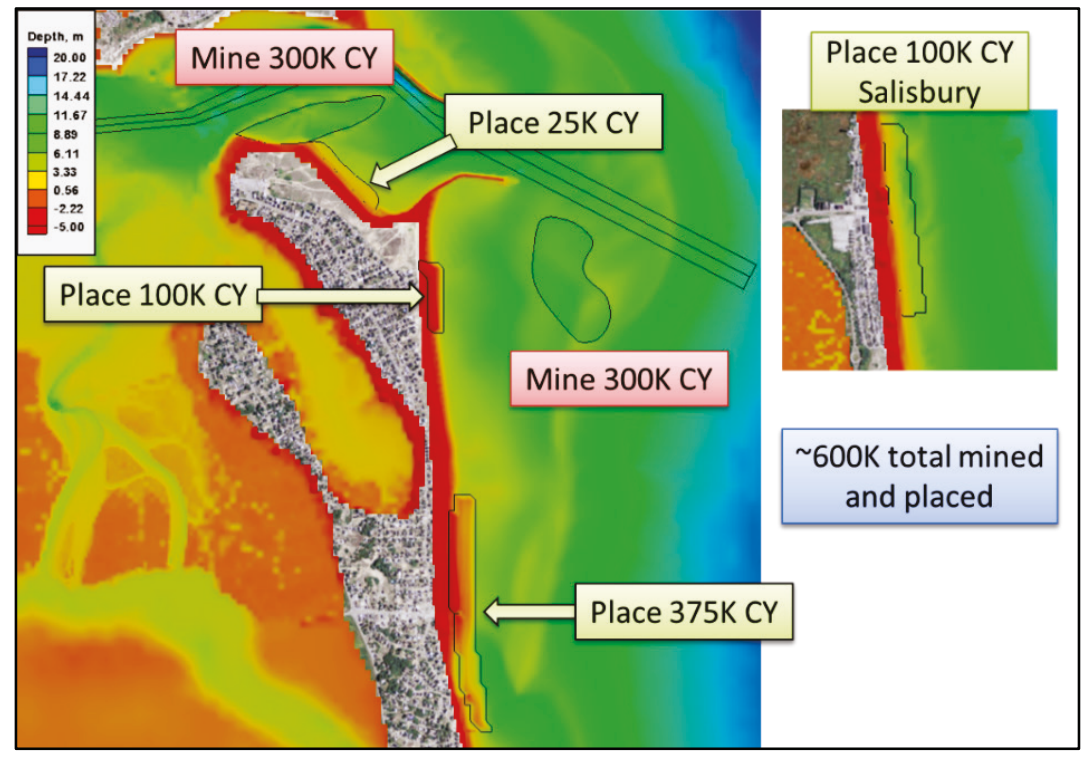


Ebb Delta Mining and Modified Placement Area, Alternative 17

This alternative removes $229,366 \mathrm{~m}^{3}$ (300,000 cu yd) of material from modified ebb delta mining area from Alternative 16 and places that material in the nearshore, below the southern extent of a natural bar where a gap was detected after the 2014 lidar survey. This alternative is shown in Figure 53 below.

Figure 53. Alternative 17: Ebb Delta mining with placement offshore of Plum Island to extend a natural bar formation (in this figure, $\mathrm{CY}=$ cubic yards).

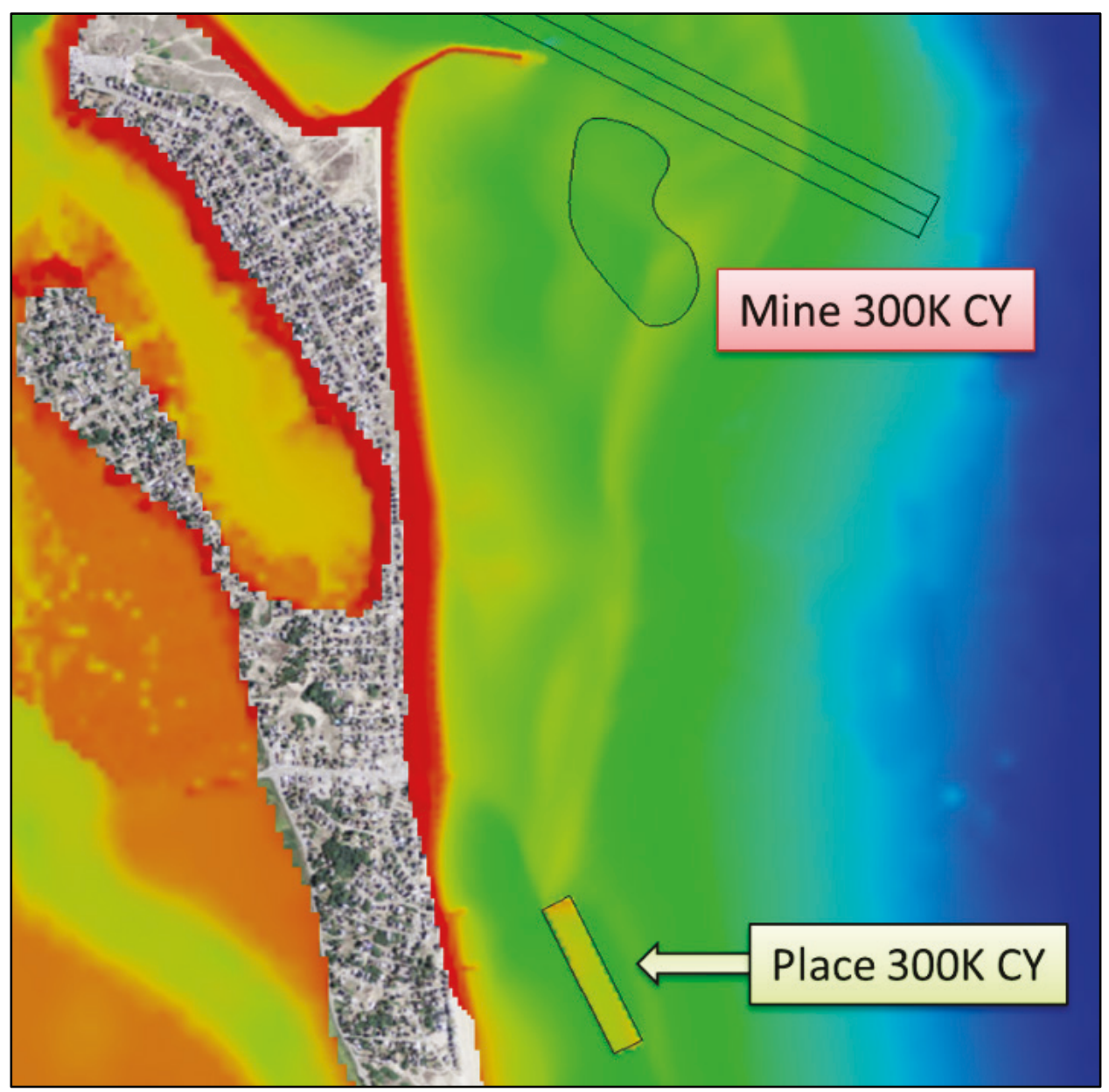




\section{Results and Discussion}

\subsection{Phase I}

\subsubsection{CMS calibration}

The bathymetry data described in Section 2.4 were interpolated to configure the numerical model grid. Waves, wind, WSE, and river flow data were assembled to provide forcing terms to the CMS at surface, offshore, and estuary boundaries (Figure 8, Figure 11, Figure 13, and Figure 15). Model calibration was conducted with the 2011 prerehabilitation condition of the South Jetty. Calibration procedures include defining a close representation of tidal prism, the spatial distribution of bottom friction and sediment grain sizes. The calibration period was for the month of September 2012. The field measurements were analyzed, and the model results were compared to water level and currents measured at tidal and ADCP stations as shown in Figures 17 and 18. Note that the ADCP stations are nearest to the South Jetty and are not in alignment with maximum tidal flow at the inlet throat. Preferably, a 2D hydrodynamic model of a tidal inlet would be calibrated and validated based on multiple tide and current measurements across the domain with the primary validation point being located within the inlet throat.

For general coastal applications, the default Manning's $n$ value of 0.025 is used in the CMS. However, the present model domain focuses on an inlet system where jetty structure and navigation channel have significant influence on regulating currents through the system. Considering the existence of structures surrounding the inlet hard (non-erodible) bottom was specified around jetties and channel, over which Manning's $n$ was tuned up to obtain better current calibration results. Figure 54 shows the specifications of non-erodible areas and spatially varying Manning's $n$ in the CMS. The hard-bottom areas correspond to the inlet jetties and the deepest portion of the navigation channel. Manning's $n$ ranges from 0.021 to 0.045 . The lowest value was specified for the Sound and offshore area and the highest value for the jetty area. Single-grain size sediment transport modeling was conducted in the Phase I study. Referring to the sediment grab samples by NAE (Figure 19), the sediment transport grain size, $D_{50}$, is $0.32 \mathrm{~mm}$. The varying bed grain sizes, $D_{50}$, were specified and shown in Figure 55. Finer grain size of $0.2 \mathrm{~mm}$ was specified for the offshore area and medium grain size of $0.32 \mathrm{~mm}$ for the Sound and 
channel area. The north spit of Plum Island experiences frequent erosion by tidal current and coarser grain size was specified for the area. The settings and adjustment of model configuration, bottom friction, and bed sediment grain sizes show current sensitivity in response to tide, wind and wave forcing, and yield a better comparison between the ADCP measurements and the CMS calculations.

Figure 54. Specifications of (a) non-erodible bed and (b) Manning's $n$.

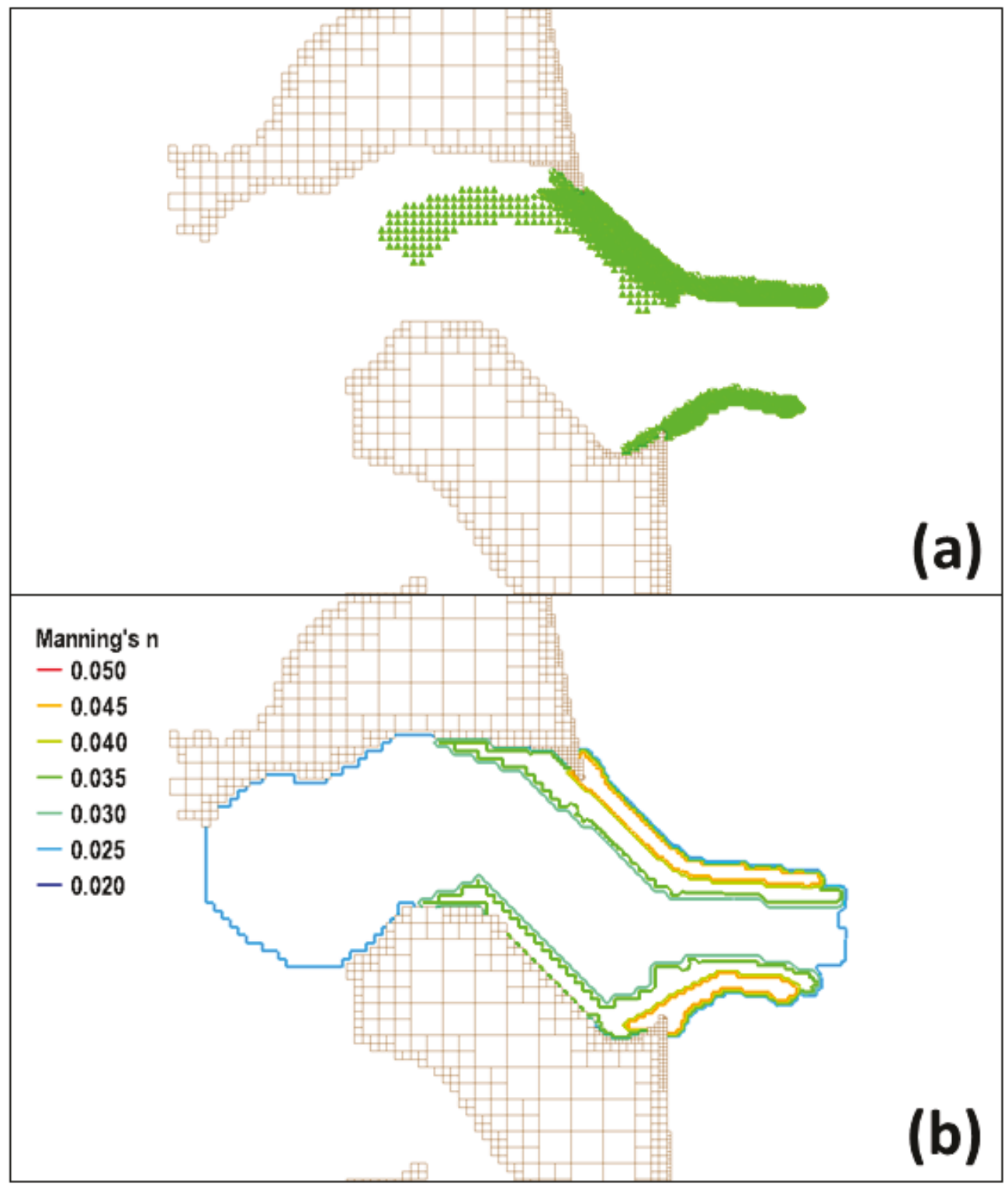


Figure 55 . Specifications of varying bed grain sizes $\left(D_{50}\right)$.

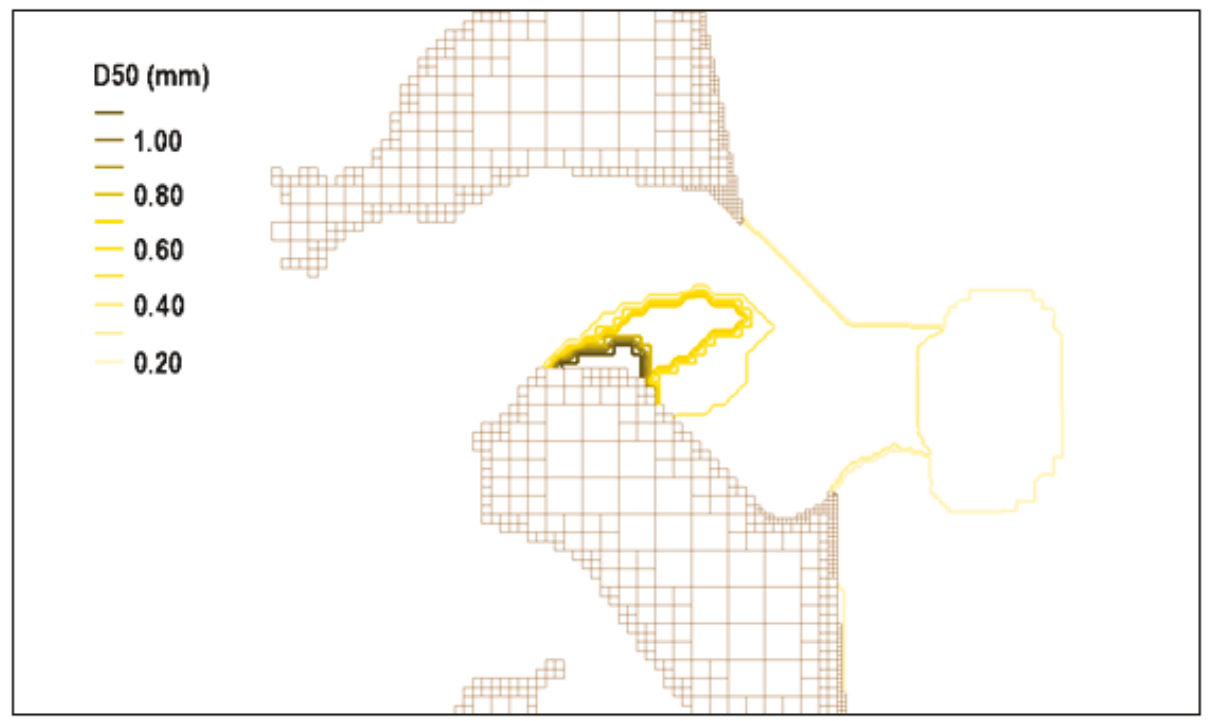

Figure 56 shows the calculated and measured WSE at the four tidal gauges in the Plum Island Sound. Both the measurements and calculations show that the spring tidal amplitude is close to 3.5 to $4 \mathrm{~m}$ (11.5 to $13.1 \mathrm{ft}$ ) in the area. Visual inspection indicates that the CMS results well reproduce the amplitude and phase of tide.

Figure 56. Comparison of measured (blue line) and calculated (red line) water levels in Plum Island Sound.

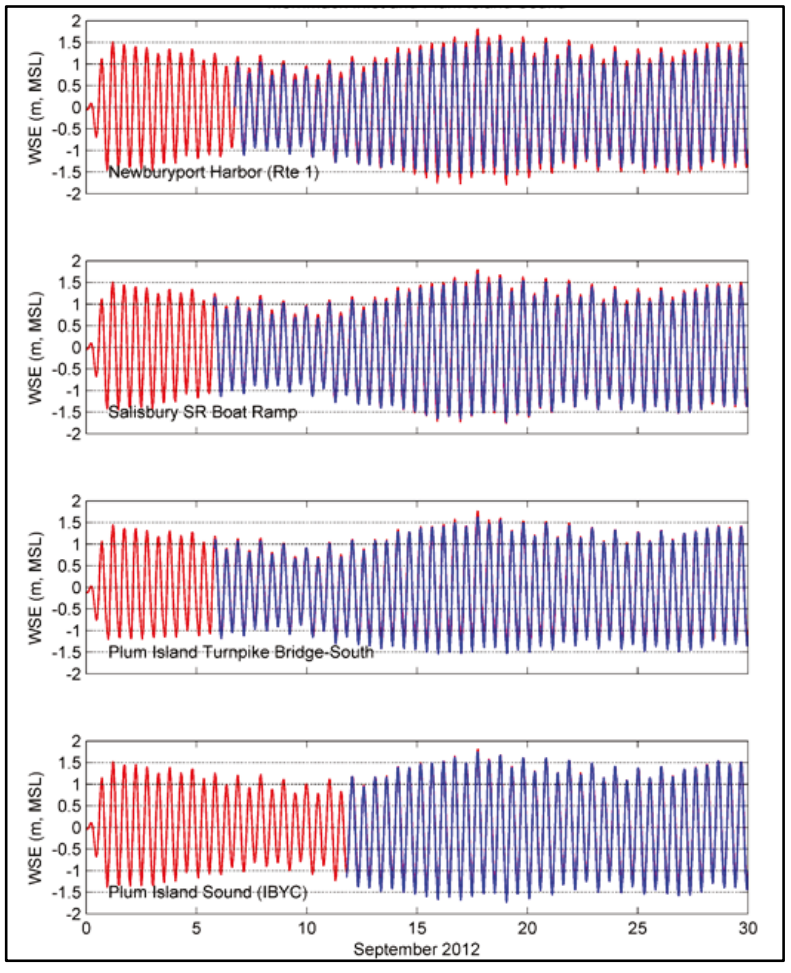


To demonstrate model skill, goodness-of-fit statistics were calculated to determine the level of calibration, including the correlation coefficient (R), the root-mean-square error (RMSE), and the normalized root-meansquare error (NRMSE) as shown in Table 3-1. The correlation coefficient $\mathrm{R}$ measures the linear co-variation between two datasets and can range from -1 to 1 , with negative $R$ values indicating inverse correlation and a value of 1 indicating perfect agreement. The correlation for the water level measurements is extremely good, ranging from 0.982 to 0.999 . The RMSE measures the actual differences between the measured and calculated datasets, and ranges from 0.069 to $0.209 \mathrm{~m}$. The NRMSE is defined as RMSE divided by the data range and measures the relative differences between the measured and calculated datasets and ranges from $2 \%$ to $6 \%$ at the four tidal gauges.

Table 3-1. Water level goodness of fit statistics: September 2012 field data.

\begin{tabular}{|l|c|c|c|}
\hline \multicolumn{1}{|c|}{ Gauge } & $\begin{array}{c}\text { Correlation } \\
\text { Coefficient (R) }\end{array}$ & RMSE $(\mathrm{m})$ & NRMSE, \% \\
\hline $\begin{array}{l}\text { Newburyport Harbor } \\
\text { (Rt-1) }\end{array}$ & 0.982 & 0.209 & 5.9 \\
\hline $\begin{array}{l}\text { Merrimack Inlet (SSR } \\
\text { Boat Ramp) }\end{array}$ & 0.994 & 0.127 & 3.6 \\
\hline $\begin{array}{l}\text { Plum Island Tpk Bridge- } \\
\text { South }\end{array}$ & 0.993 & 0.128 & 3.7 \\
\hline $\begin{array}{l}\text { Plum Island Sound } \\
\text { (IBYC) }\end{array}$ & 0.999 & 0.069 & 2.0 \\
\hline
\end{tabular}

Figure 57 shows a snapshot of the depth-averaged flood (a) and ebb (b) current fields on 17 September 2012 at 14:00 and 20:00 Greenwich Mean Time (GMT), respectively, during a spring tidal period (Figure 13). Strong currents occurred at the inlet. The maximum current speed is approximately $1.3-1.4 \mathrm{~m} / \mathrm{s}(4.3-4.6 \mathrm{ft} / \mathrm{s})$ in the navigation channel. Due to the loss of the channel ADCP gauge, no data were available to compare to computed channel velocities. At the two ADCP locations in the vicinity of the South Jetty, currents are relatively weak with a maximum speed of $0.2-0.3 \mathrm{~m} / \mathrm{s}(0.66-0.98 \mathrm{ft} / \mathrm{s})$. A small eddy formed close to the South Jetty during the ebb tide and was captured by the Inlet ADCP station. 
Figure 57. Simulated depth-averaged (a) flood and (b) ebb currents on 17 September 2012 at 14:00 and 20:00 GMT, respectively.
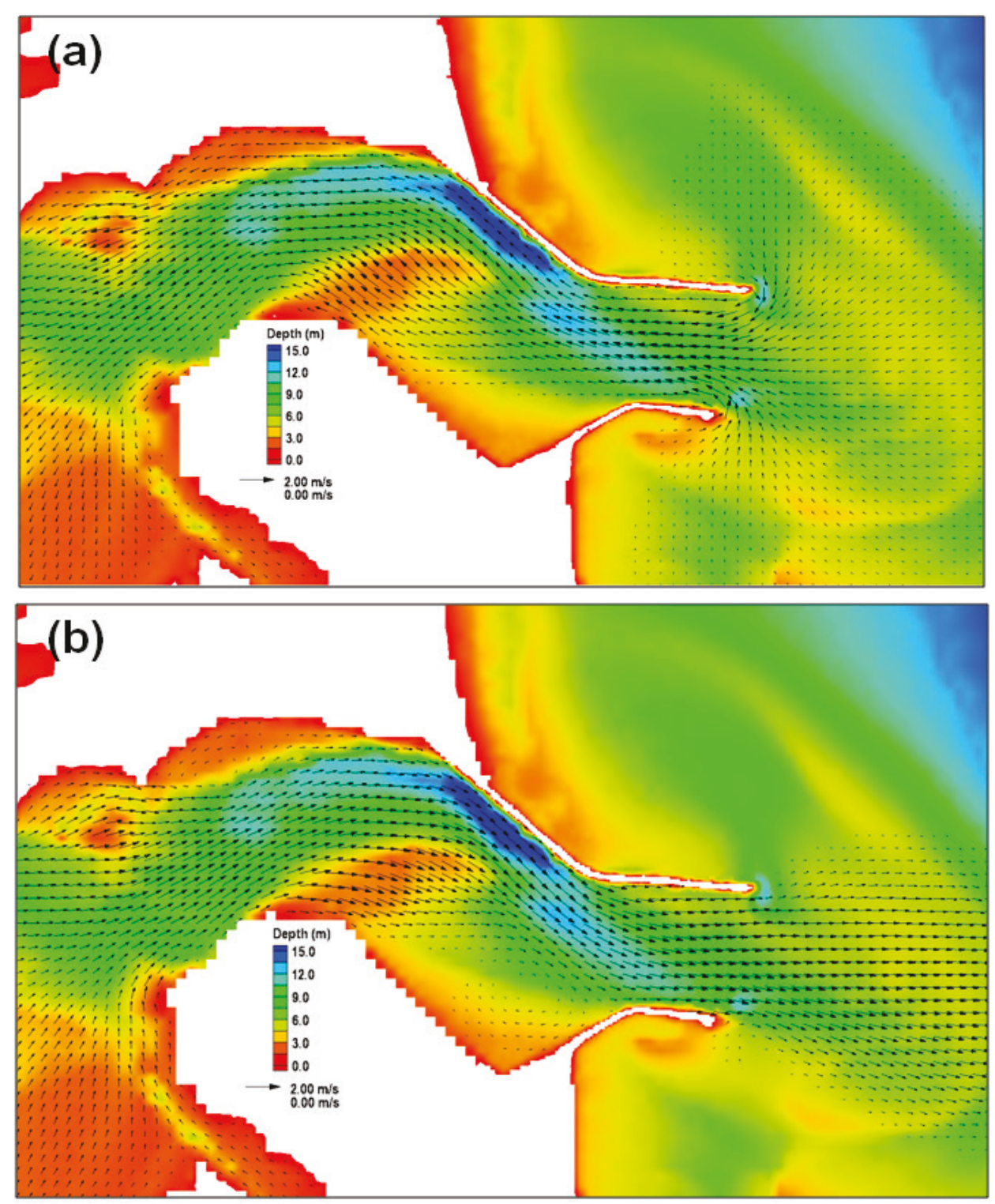

The model results are compared to the east-west $(u)$ and north-south $(v)$ components of the current data measured at the inlet and downdrift ADCP gauges (Figure 58). The current measurements show weak but clear tidal signals. The measured currents at the inlet gauge ranged from $-0.6 \mathrm{~m} / \mathrm{s}$ ( $2 \mathrm{ft} / \mathrm{s}$ ) (westward) to $0.5 \mathrm{~m} / \mathrm{s}(1.6 \mathrm{ft} / \mathrm{s}$ ) (eastward) in the $u$-direction, and 0.0 to $0.5 \mathrm{~m} / \mathrm{s}(1.6 \mathrm{ft} / \mathrm{s})$ (northward) in the $v$-direction. The magnitude of current in the positive $v$-direction indicates significant flow over the South Jetty during flood tide, as would be expected by the degraded condition of the South Jetty in 2011. Current speeds at the downdrift gauge are less in magnitude, ranging from -0.2 to $0.1 \mathrm{~m} / \mathrm{s}(-0.7$ to $0.3 \mathrm{ft} / \mathrm{s})$ in the $u$-direction and -0.1 to $0.1 \mathrm{~m} / \mathrm{s}$ (-0.3 to $0.3 \mathrm{ft} / \mathrm{s}$ ) in the $v$-direction. 
Figure 58. Simulated and measured currents in Merrimack Inlet.

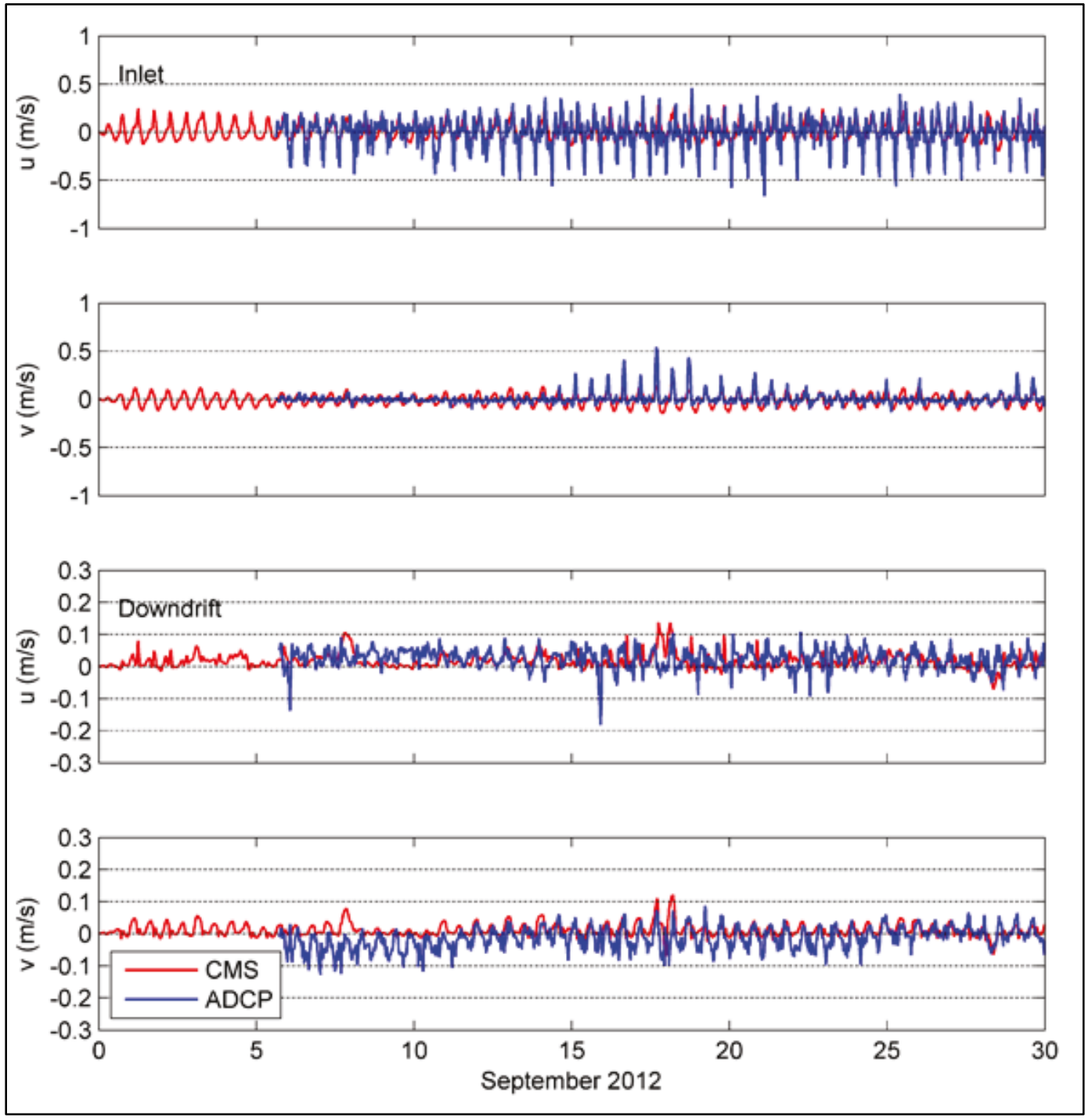

Table 3-2 details the goodness of fit statistics for the gauges. The RMSE for the current data ranges from 0.04 to $0.14 \mathrm{~m} / \mathrm{s}(0.1$ to $0.5 \mathrm{ft} / \mathrm{s})$. The correlation coefficient $\mathrm{R}$ ranges from 0.01 for the $u$ (east-west) component at the downdrift gauge, which is influenced by wave breaking and crossshore flow, to 0.48 for the $u$ (east-west) component at the inlet gauge, which measures tidal currents through the inlet. Thus, compared to the weaker currents measured at the downdrift gauge, the CMS is in better agreement for the larger magnitude of current speed as measured at the inlet gauge.

This performance is most likely due to a combination of the representation of the structure in the model and the location of the downdrift ADCP, which is sheltered from direct wave action. When the measured current 
speeds and the ADCP measurement errors were of the same order of magnitude, any small disturbances could contribute to the model and data comparisons greatly. Inspection of the measured data also revealed a vertical structure in the current profiles due to the interaction between tidal currents and jetties, which was difficult for a 2D hydrodynamic model to reproduce. Additionally, this model did not consider flow through the jetty due to high permeability from degradation, which may be contributing to the under prediction of the CMS under certain conditions. Unfortunately, post-jetty rehabilitation flow measurements are not available to compare and contrast differences in flow patterns and magnitudes due to decreased permeability.

Table 3-2. Current goodness of fit statistics: September 2012 field data.

\begin{tabular}{|l|c|c|c|c|c|c|}
\hline \multirow{2}{*}{\multicolumn{1}{|c|}{ Gauge }} & \multicolumn{2}{|c|}{$\begin{array}{c}\text { Correlation } \\
\text { Coefficient (R) }\end{array}$} & \multicolumn{2}{c|}{ RMSE (m/s) } & \multicolumn{2}{c|}{ NRMSE (50) } \\
\cline { 2 - 7 } & $\mathrm{u}(\mathrm{E}-\mathrm{W})$ & $\mathrm{v}(\mathrm{N}-\mathrm{S})$ & $\mathrm{u}(\mathrm{E}-\mathrm{W})$ & $\mathrm{v}(\mathrm{N}-\mathrm{S})$ & $\mathrm{u}(\mathrm{E}-\mathrm{W})$ & $\mathrm{v}(\mathrm{N}-\mathrm{S})$ \\
\hline South Jetty inlet & 0.479 & 0.475 & 0.143 & 0.067 & 13.0 & 11.2 \\
\hline $\begin{array}{l}\text { South Jetty } \\
\text { downdrift }\end{array}$ & 0.009 & 0.391 & 0.039 & 0.042 & 13.0 & 16.8 \\
\hline
\end{tabular}

\subsubsection{CMS validation}

The model was validated for the 2011 pre-rehabilitation condition with water level and current data from October 2012. The calculated results were compared with the tidal and ADCP gauge data (Figures 17 and 18), and the model performance was measured by goodness-of-fit statistics.

Figure 59 shows the calculated and measured WSEs at the four tidal gauges in the Plum Island Sound. Similar to the calibration case, the measurements and calculations show a good agreement. A small storm surge occurred near the end of the 30-day simulations as indicated by the increase in WSEs. The CMS results well reproduce the tidal and the lowfrequency signals displayed in the survey. 
Figure 59. Comparison of measured (blue line) and calculated (red line) water levels in Plum Island Sound.

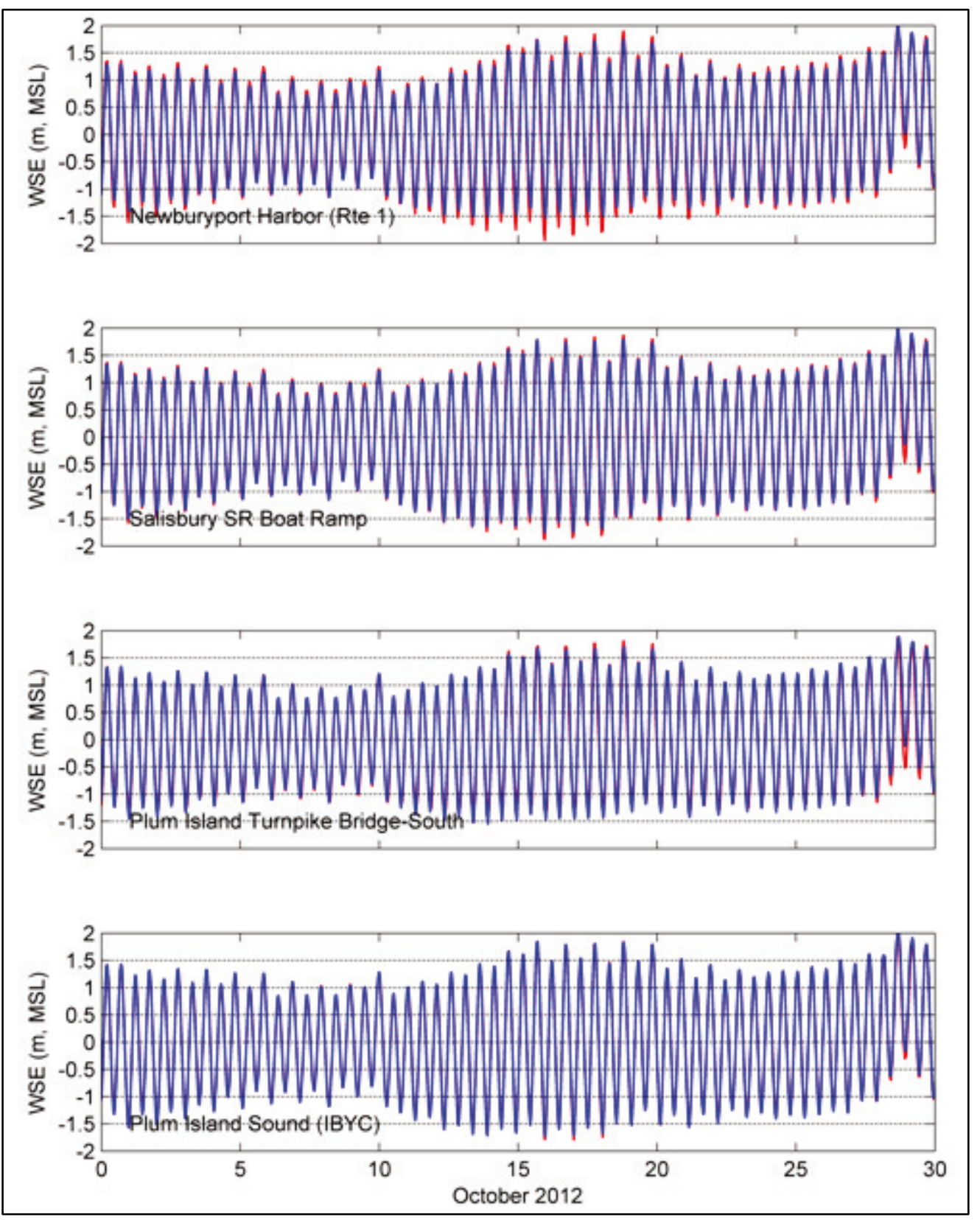

The goodness-of-fit statistics for the validated WSEs is listed in Table 3-3. The correlation for the water level measurements was very good, ranging from 0.983 to 0.999 . The RMSE and the NRMSE range from 0.050 to $0.190 \mathrm{~m}$ ( 0.2 to $0.6 \mathrm{ft}$ ) and from $1.4 \%$ to $5.4 \%$ at the four tidal gauges, respectively. 
Table 3-3. Water level goodness of fit statistics: October 2012 field data.

\begin{tabular}{|l|c|c|c|}
\hline \multicolumn{1}{|c|}{ Gauge } & $\begin{array}{c}\text { Correlation } \\
\text { Coefficient (R) }\end{array}$ & RMSE (m) & NRMSE (\%) \\
\hline $\begin{array}{l}\text { Newburyport } \\
\text { Harbor (Rt-1) }\end{array}$ & 0.983 & 0.190 & 5.4 \\
\hline $\begin{array}{l}\text { Merrimack Inlet } \\
\text { (SSR Boat Ramp) }\end{array}$ & 0.994 & 0.117 & 3.3 \\
\hline $\begin{array}{l}\text { Plum Island Tpk } \\
\text { Bridge-South }\end{array}$ & 0.991 & 0.120 & 3.4 \\
\hline $\begin{array}{l}\text { Plum Island Sound } \\
\text { (IBYC) }\end{array}$ & 0.999 & 0.05 & 1.4 \\
\hline
\end{tabular}

The model results are compared to the east-west $(u)$ and north-south $(v)$ components of the current data measured at the inlet and downdrift ADCP gauges (Figure 60). Table 3-4 lists the goodness of fit statistics for the gauges. The RMSE for the current comparison at the inlet gauge shows a relatively high correlation. At the downdrift gauge, only the $v$ (east-west) component has a higher correlation; the $u$-component shows little correlation. Depending on the magnitude of current speed, the RMSE varies, but the NRMSE does not show any improvement over the calibration results. The results of model validation are comparable to those of model calibration.

The current comparisons are not ideal. But the inlet location is off the channel, and the downdrift location is protected by the South Jetty. Both the measurements and the model results at these sites show relatively weak currents. Because of small current speed, any perturbation due to instrument instability could result in inconsistency in model-data comparisons significantly, such as measured $u$-component spike at the downdrift ADCP approximately 15 September 2012. Also, the subsequent calculations of sediment movement, mainly corresponding to strong channel current around the inlet system, may not miss key features of inlet morphology changes. 
Figure 60. Simulated and measured currents in Merrimack inlet for October 2012.

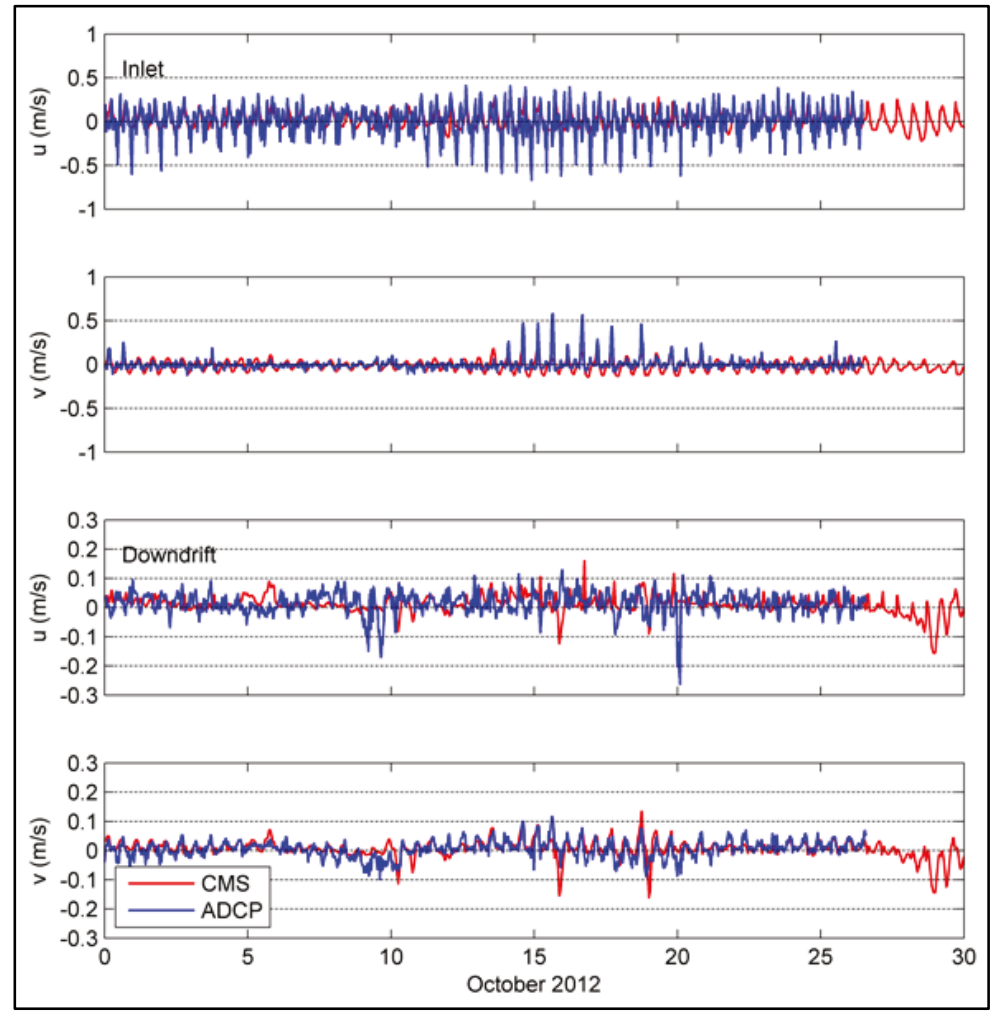

Table 3-4. Current goodness of fit statistics: October 2012 field data.

\begin{tabular}{|l|c|c|c|c|c|c|}
\hline \multirow{2}{*}{ Gauge } & \multicolumn{2}{|c|}{ Correlation Coefficient (R) } & \multicolumn{2}{c|}{ RMSE (m/s) } & \multicolumn{2}{c|}{ NRMSE (\%) } \\
\cline { 2 - 7 } & $u(\mathrm{E}-\mathrm{W})$ & $v(\mathrm{~N}-\mathrm{S})$ & $u(\mathrm{E}-\mathrm{W})$ & $v(\mathrm{~N}-\mathrm{S})$ & $u(\mathrm{E}-\mathrm{W})$ & $v(\mathrm{~N}-\mathrm{S})$ \\
\hline $\begin{array}{l}\text { South Jetty } \\
\text { Inlet }\end{array}$ & 0.451 & 0.413 & 0.155 & 0.075 & 14.1 & 10.7 \\
\hline $\begin{array}{l}\text { South Jetty } \\
\text { Downdrift }\end{array}$ & -0.079 & 0.518 & 0.046 & 0.028 & 13.1 & 11.2 \\
\hline
\end{tabular}

For the validation of sediment transport, calculated morphology change results are qualitatively compared with measurements obtained by the latest dredging data at the inlet entrance navigation channel $(4.6-\mathrm{m}(15 \mathrm{ft}$ channel). Two channel surveys span a 19-month period in February 2009 and September 2010. It is not practical to run a long-term simulation for this study because of time constraints. Trying to include a period with more wave action, a one-winter-month simulation was set up. Figure 61(a) shows the morphology change based on channel surveys, and Figure 61(b) is the calculated morphology change at the end of a 1-month simulation of January 2011. Warmer colors indicate sediment deposition while cooler colors represent erosion. The major morphologic features represented and 
the morphodynamics illustrated both in the measurements and in the model include (a) jetty tip scour, which can be an ongoing perturbation that grows or shrinks linearly over timescales of months to years, (b) channel thalweg migration, and (c) ebb tidal delta distal bar migration, for which the positioning is dependent upon the seasonal wave activity. In general, the trends of these features are captured; however, it is not reasonable to do a one-to-one comparison between the 1-month simulation and the 19-month measured change.

Figure 61. Measured (a) and calculated (b) Morphology change along the $15 \mathrm{ft}$ navigation channel.
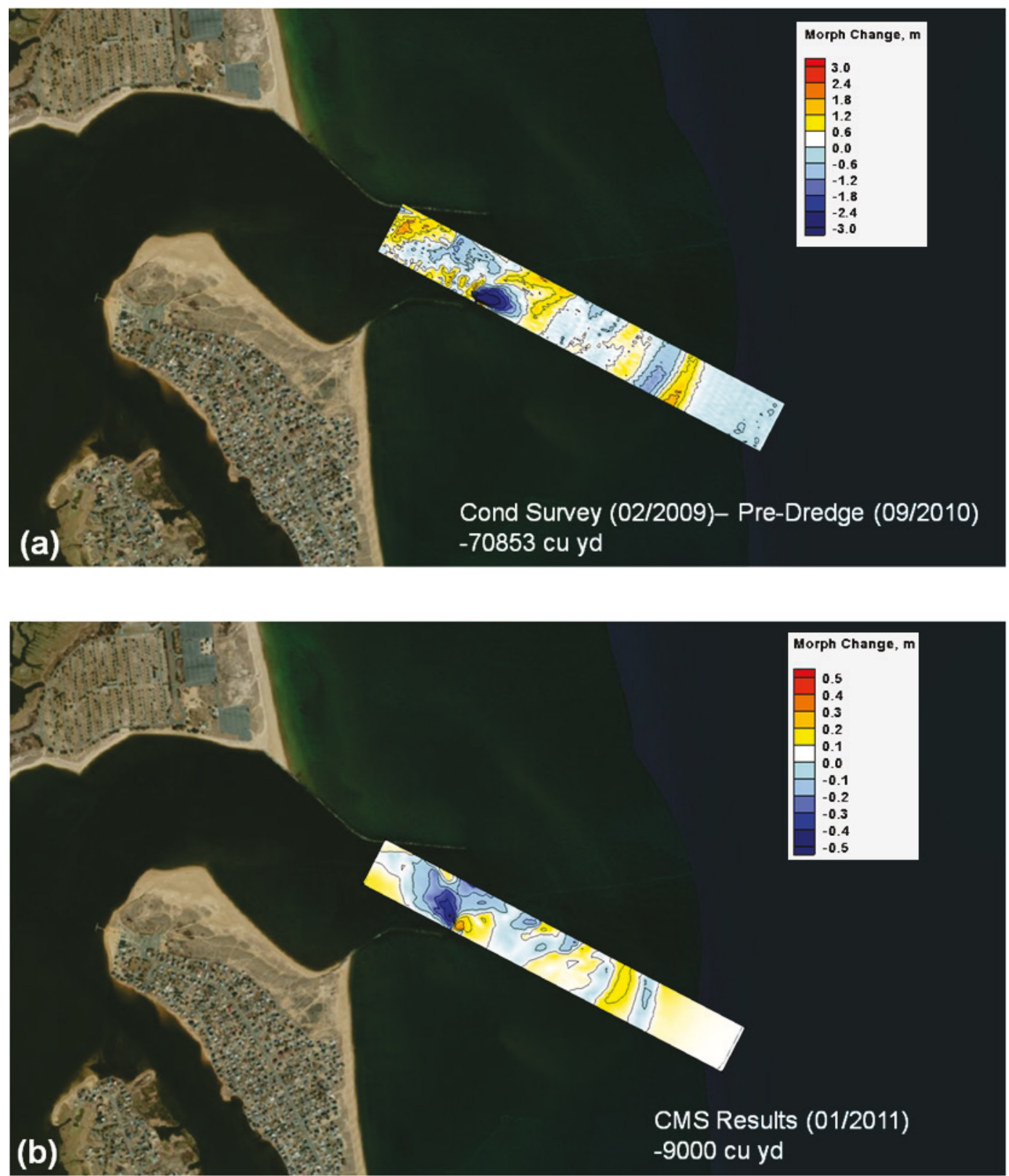


\subsubsection{Representative winter and summer simulations}

Based on historical wave, wind, and freshwater inflow data, September 2012 and January 2011 were selected as the representative low-energy and high-energy months, respectively, to analyze the pre-rehabilitation condition scenarios. The two simulations were conducted with the calibrated and validated CMS model setup (Figures 54, and 55). The highenergy month conditions provided a baseline for the greatest change and were therefore used for the comparisons of all 15 alternatives.

Mean current (top two panels in Figure 62) and corresponding mean sediment transport (bottom two panels in Figure 62) were obtained by averaging hourly model output over the simulation periods. As shown in the figure, the mean flow and sediment transport are towards the open ocean. The mean current speeds and net sediment transport calculated for the winter month are stronger than the summer-fall month. This is especially true for the downdrift long-shore transport components, which are due to storms and waves.

Figure 62. Simulated mean current and sediment transport for September 2012 and January 2011.

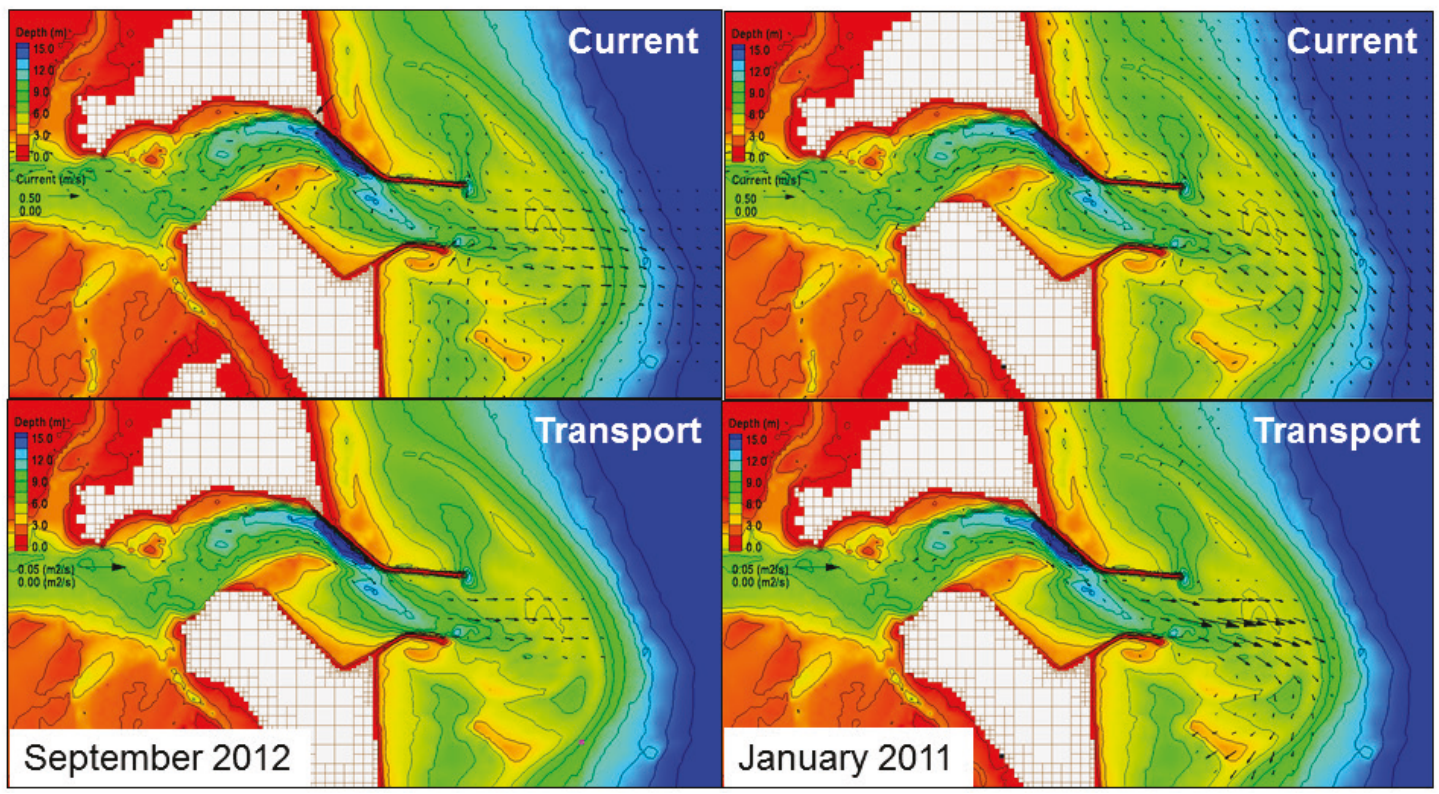

The morphology change at the end of each 1-month simulation shows the sediment accumulation and sand bar formation around the ebb shoal for September 2012 and January 2011 (Figure 63), with greater morphologic change calculated for the winter month corresponding to higher energy events. 
Figure 63. Simulated morphology changes for September 2012 and January 2011.
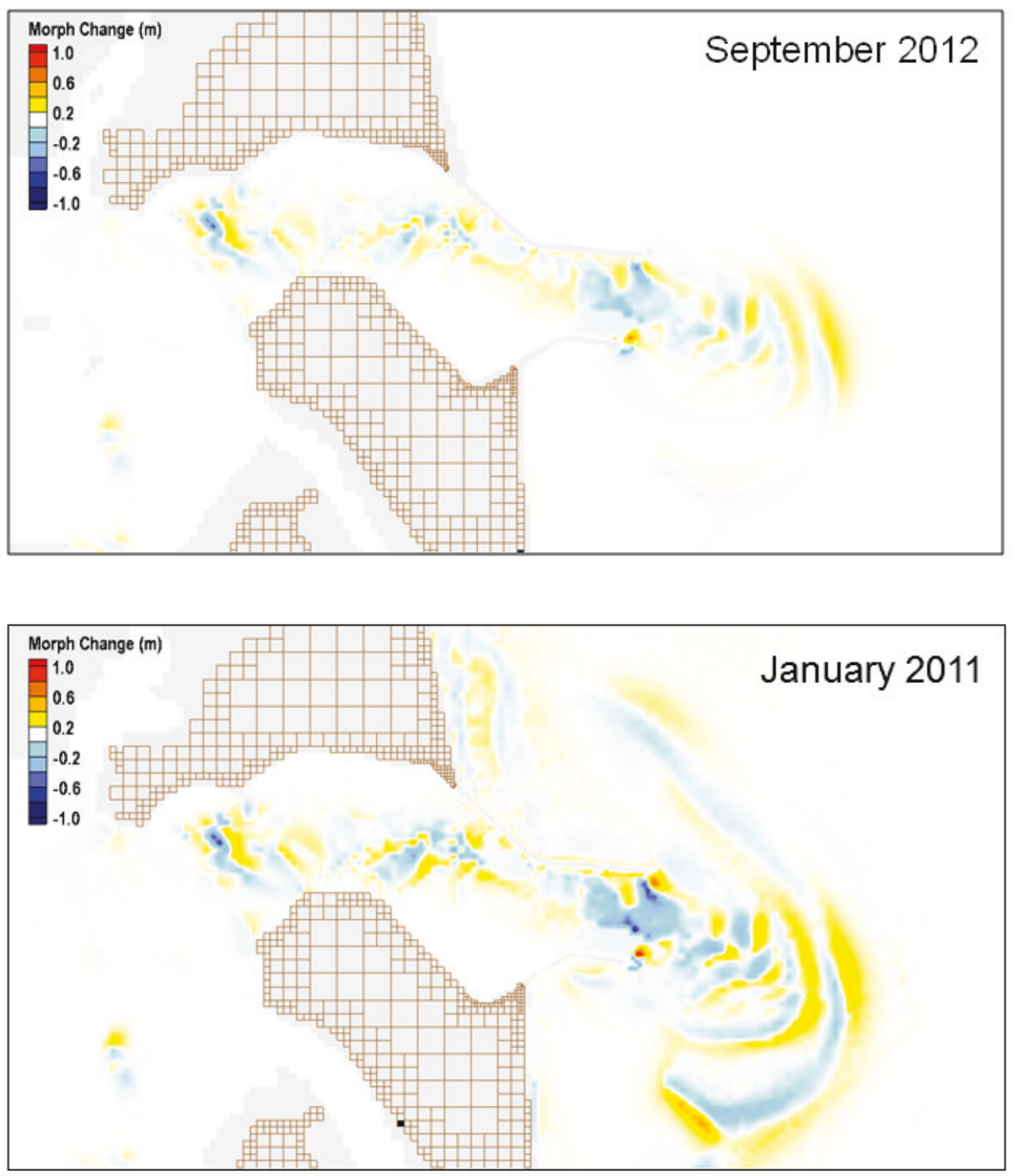

\subsubsection{Partially rehabilitated South Jetty condition}

As described in section 2.5.1.2, the South Jetty at Merrimack Inlet underwent a partial rehabilitation. This configuration was used for each alternative discussed in Phase I.

\subsubsection{Base condition}

A base condition was run for the same time periods as all of the 1-month and 6-month alternative simulations in Phase I. The base condition uses existing bathymetry at the time when the South Jetty was partially rehabilitated (October 2011 lidar survey). To compare the changes that result from each alternative, the morphology change due to the base 
condition is removed from that due to each alternative and will be referred to as the resulting morphology change. As an example, Figure 64 and Figure 65 show the simulated morphology changes for the base condition and Alternative 1 and the resulting morphology change due to Alternative 1. This resulting change describes morphology change patterns after the 1-month and 6-month simulations due to alternatives.

Figure 64. Simulated morphology changes for the base condition (left panel) and Alternative 1 (right panel) results after the 1-month simulation.
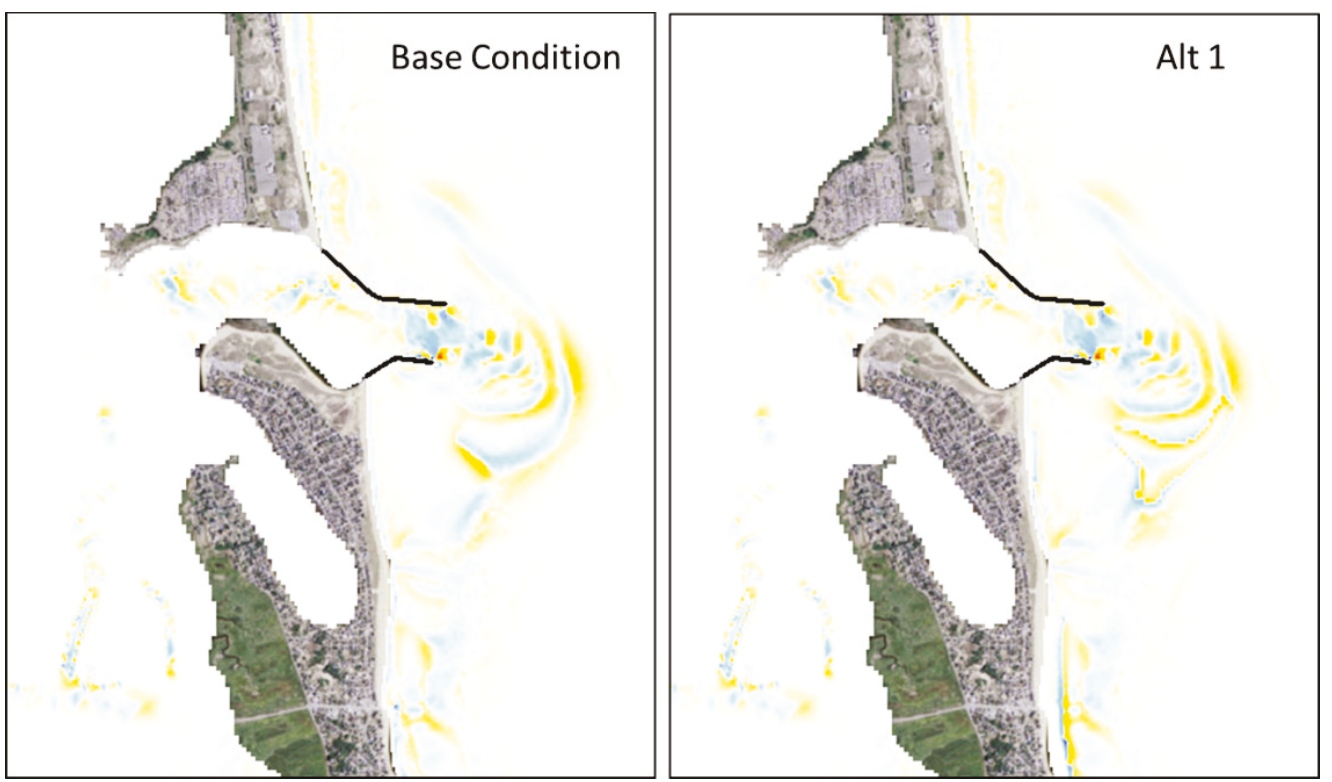

Figure 65. Resulting morphology change due to Alternative 1.

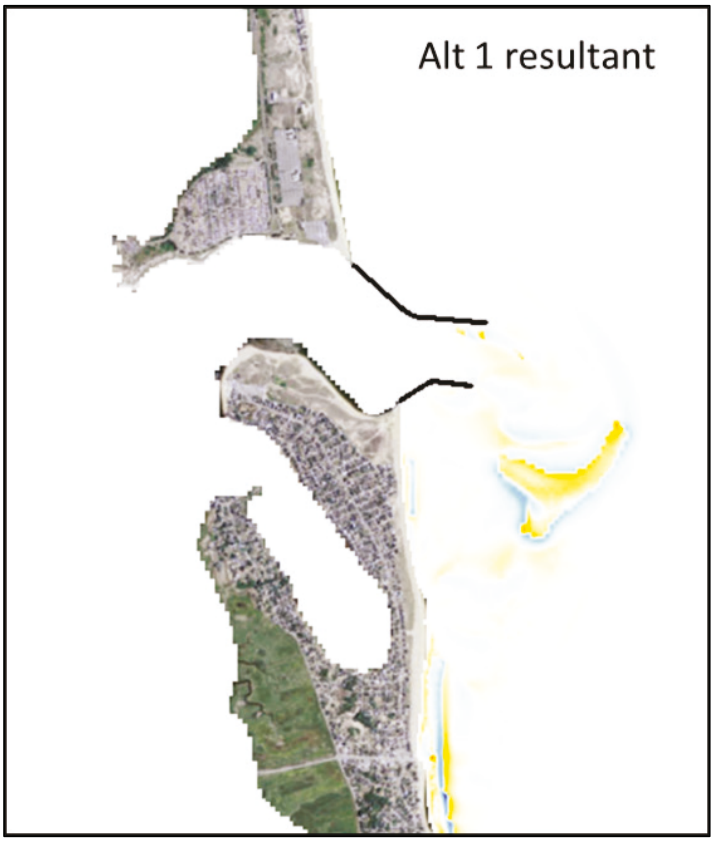




\subsubsection{Sediment management alternatives}

\section{Ebb Delta Mining, Alternative 1 (1 Month)}

Figure 66 shows the same resulting morphology changes for Alternative 1 as in Figure 65 but with mining and placement areas outlined. Ebb delta mining creates a void, and nearshore placement generates mounds at the seabed. After the 1-month simulation, sand tends to move to fill in the mined area and to erode from the placement area. Comparing with the base condition, approximately 12,002 more m3 (15,700 cu yd) of sediment (3.1\% of mined $383,250 \mathrm{~m}^{3}$ [500,000 cu yd]) of sediment) filled in the mined area. A small amount of placed material (1,758 $\mathrm{m}^{3}$ [2,300 cu yd], 2.3\% of original placed $76,450 \mathrm{~m}^{3}$ [100,000 $\mathrm{cu}$ yd] of sand) eroded and moved shoreward from the Salisbury placement zone. The amounts of 764 and $6,960 \mathrm{~m}^{3}$ (1,000 and 9,100 cu yd) of placed material (2.0\% and $2.6 \%$ of original placed 38,225 and $267,575 \mathrm{~m}^{3}$ [50,000 and 350,000 cu yd] of sand) eroded and migrated shoreward in the Newburyport and Newbury placement zones, respectively.

Figure 66. Simulated resulting morphology changes for Alternative 1.

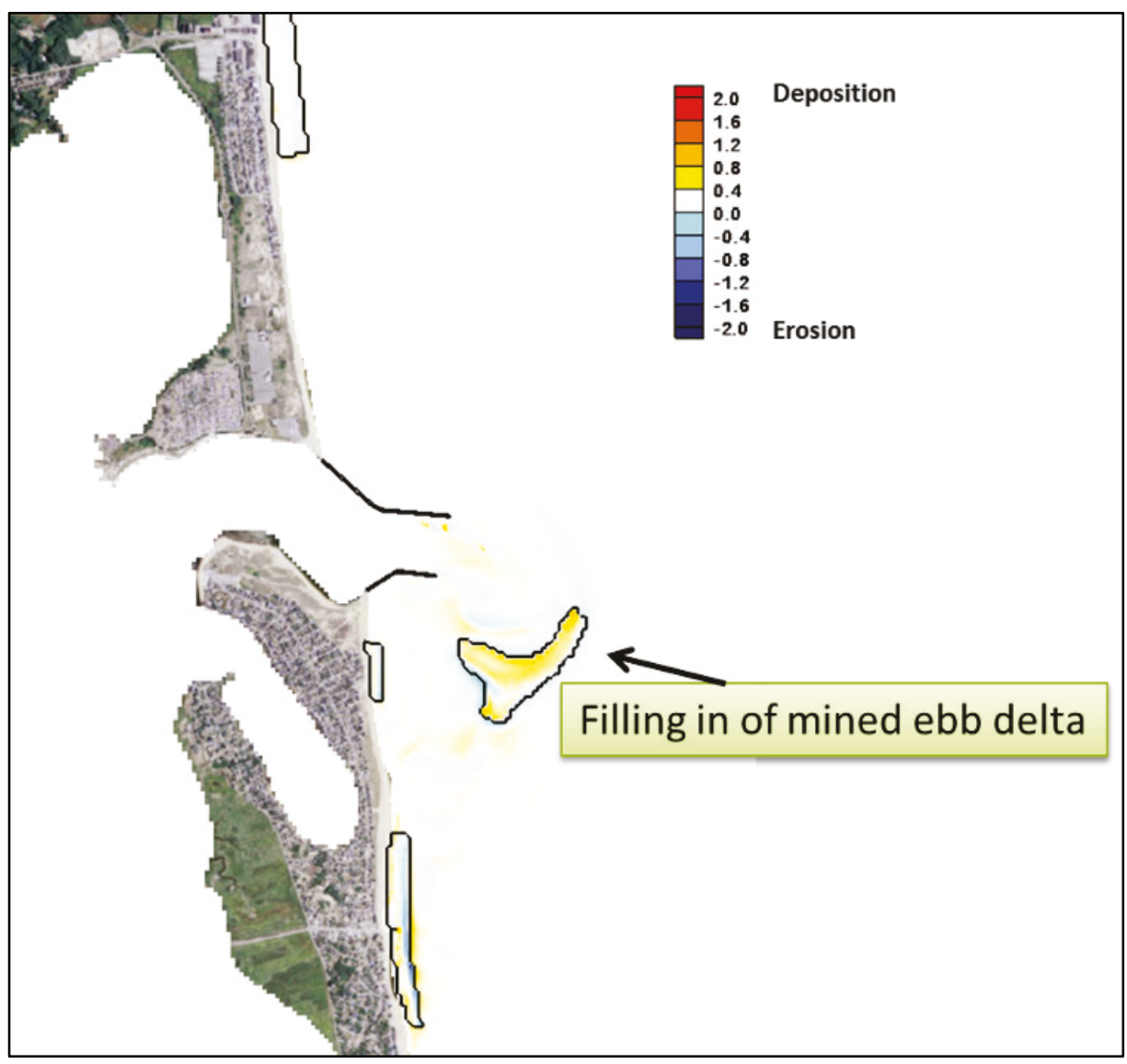




\section{Flood Delta Mining, Alternative 2 (1 Month)}

For Alternative 2 (Figure 67), there was no noticeable change in the flood tidal delta mining area because of the off-channel location of this site. Only 76 more $\mathrm{m}^{3}$ (100 cu yd) of sediment (0.02\% of mined $383,250 \mathrm{~m}^{3}$ (500,000 cu yd) of sediment) filled in the mined area. Similar to Alternative 1, a small amount of placed material (1,682 m3 (2,200 cu yd), $2.2 \%$ of original placed $76,450 \mathrm{~m}^{3}(100,000 \mathrm{cu} \mathrm{yd})$ of sand) eroded and moved shoreward from the Salisbury placement zone. The amounts of 688 and 7,033 $\mathrm{m}^{3}$ (900 and 9,200 cu yd) of placed material (1.8 and 2.6\% of original placed 38,225 and $267,575 \mathrm{~m}^{3}$ [50,000 and 350,000 cu yd] of sand) eroded and migrated shoreward in the Newburyport and Newbury placement zones, respectively.

Figure 67. Simulated resulting morphology changes for Alternative 2.

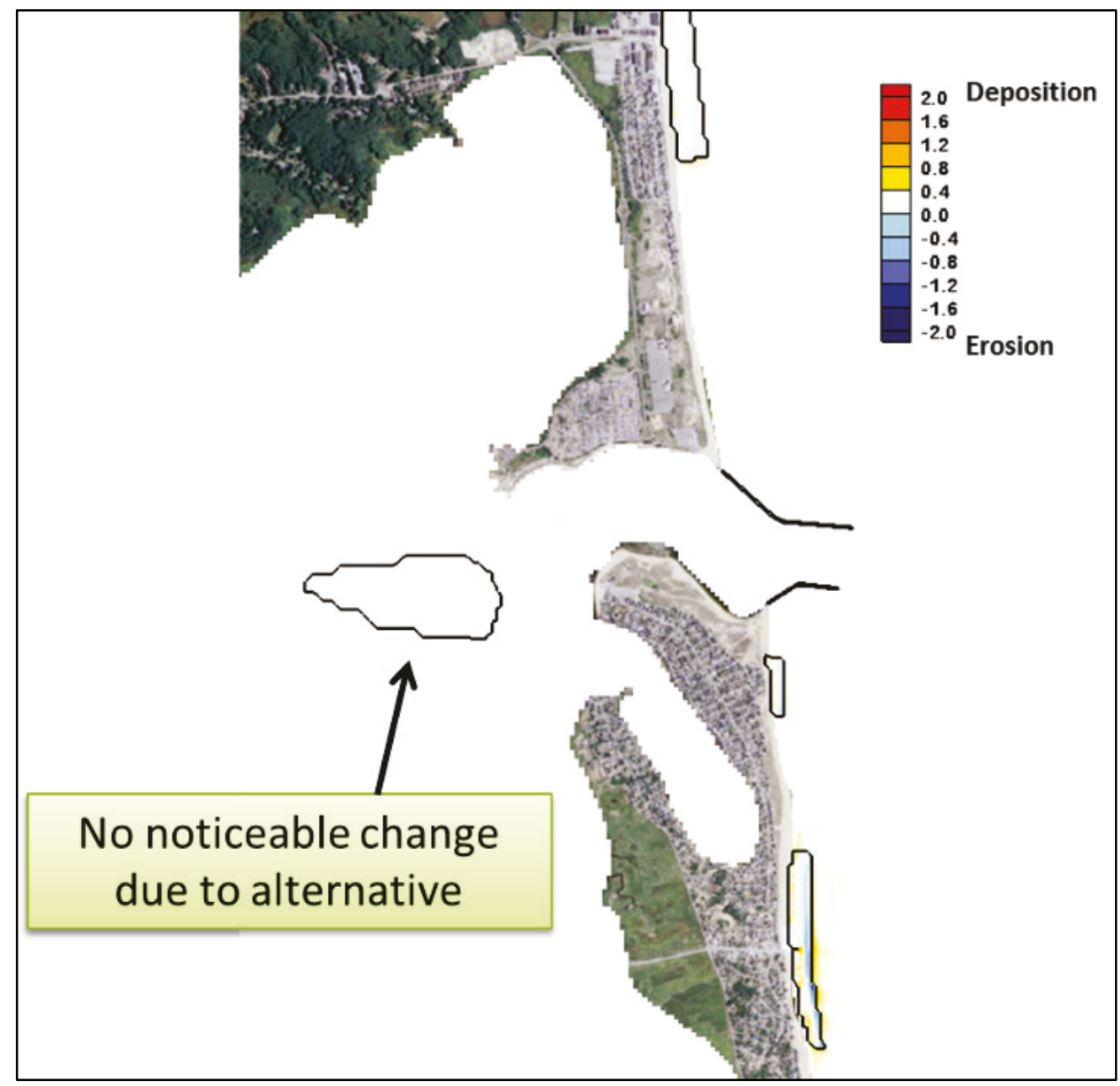




\section{North Point, Plum Island Mining, Alternative 3 (1 Month)}

For Alternative 3, the mining area at North Point is very close to the inlet channel and tidal current over the site can be as large as 1.0-1.5 m/s (3.3-4.9 ft/s). Therefore, the resulting morphology change shows a noticeable filling in the area (Figure 68). Comparing with the base condition, 2,064 more $\mathrm{m}^{3}$ (2,700 cu yd) of sediment ( $0.5 \%$ of mined $383,250 \mathrm{~m}^{3}$ (500,000 cu yd) of sediment) filled in the mined area. A small amount of placed material $\left(1,682 \mathrm{~m}^{3}\right.$ [2,200 cu yd], 2.2\% of original placed $76,450 \mathrm{~m}^{3}[100,000 \mathrm{cu} \mathrm{yd}]$ of sand) eroded and moved shoreward from the Salisbury placement zone. 688 and 7,033 $\mathrm{m}^{3}$ (900 and 9,200 cu yd) of placed material (1.8\% and $2.6 \%$ of original placed 38,225 and $267,575 \mathrm{~m}^{3}$ [50,000 and 350,000 cu yd] of sand) eroded and migrated shoreward in the Newburyport and Newbury placement zones, respectively.

Figure 68. Simulated resulting morphology changes for Alternative 3.

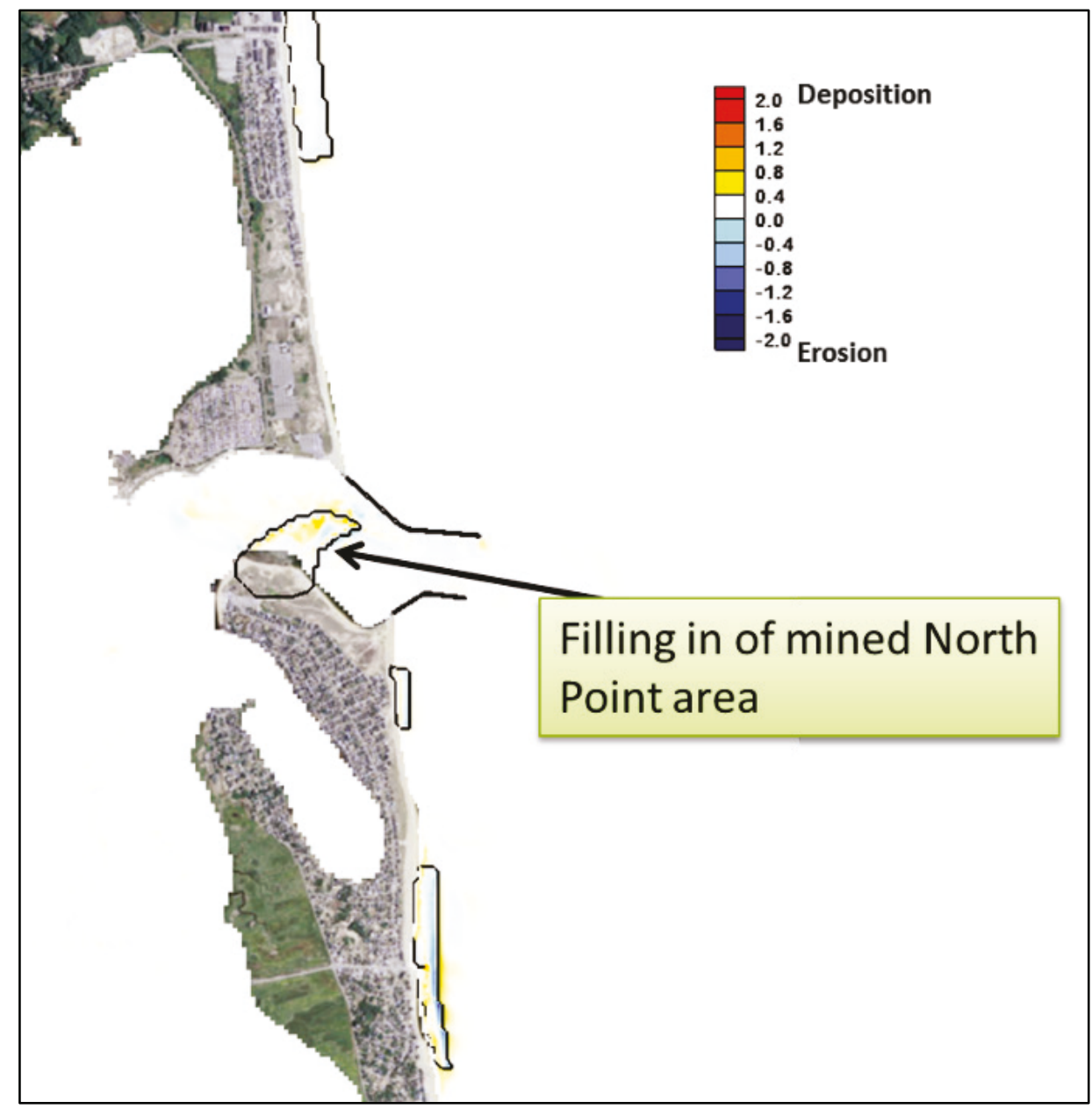


Nearshore Bar Mining, Alternative 4 (1 Month)

Instead of mining around the inlet, nearshore mining was implemented for Alternative 4 (Figure 69). As in the other mining alternatives, the morphology changes show that the region from which material was taken began to fill in during the simulation; placed sediment migrated toward the shoreline. Approximately 5,352 more $\mathrm{m}^{3}$ (7,000 cu yd) of sediment (1.4\% of mined $383,250 \mathrm{~m}^{3}[500,000 \mathrm{cu}$ yd] of sediment) filled in the mined area. Similar to Alternatives 1-3, a small amount of placed material $\left(1,682 \mathrm{~m}^{3}\right.$ [2,200 cu yd], $2.2 \%$ of original placed $76,450 \mathrm{~m}^{3}$ [100,000 cu yd] of sand) eroded and moved shoreward from the Salisbury placement zone. The amounts of 688 and 6,116 $\mathrm{m}^{3}$ (900 and 8,000 cu yd) of placed material (1.8\% and $2.3 \%$ of original placed 38,225 and $267,575 \mathrm{~m}^{3}$ [50,000 and 350,000 cu yd] of sand) eroded and migrated shoreward in the Newburyport and Newbury placement zones, respectively. Comparing with the base condition, the resulting morphology change did not show any nearshore mining impact on the adjacent ebb tidal delta.

Figure 69. Simulated resulting morphology changes for Alternative 4.

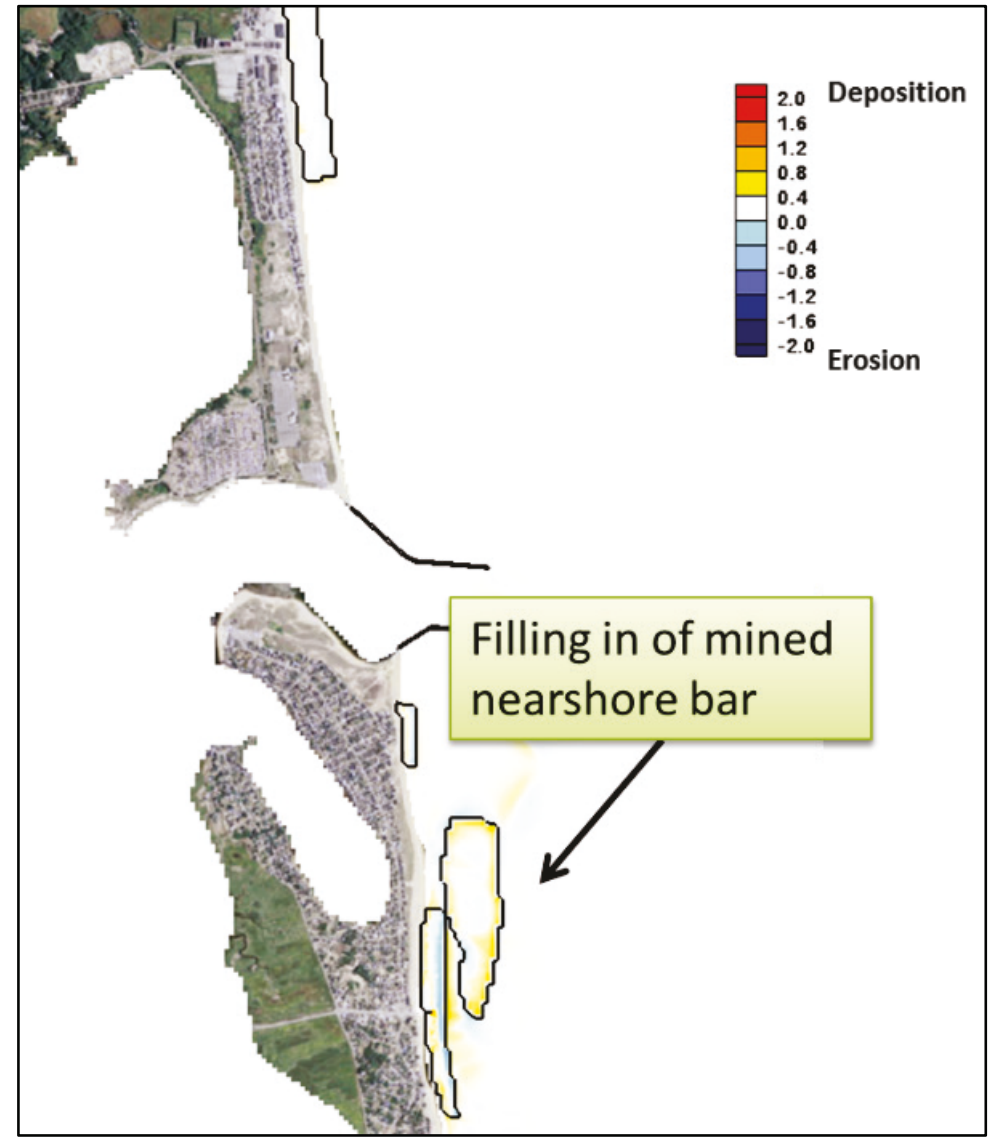




\section{Multiple Mining Locations, Alternative 5 (1 Month)}

For this alternative $458,732 \mathrm{~m}^{3}$ (600,000 $\mathrm{cu}$ yd) of sediment material were mined and placed in three locations as corresponding to Alternatives 1, 2, and 3, respectively. As shown in Figure 70, the ebb tidal delta, the north spit, and the flood tidal shoal mining areas have 5,887, 31, and 1,070 more $\mathrm{m}^{3}(7,700,40$, and $1,400 \mathrm{~K} \mathrm{cu} \mathrm{yd})$ of sediment (3.9\%, 0.02\%, and $0.7 \%$ of mined 152,900 $\mathrm{m}^{3}$ [200,000 cu yd] of sediment each) filled in, respectively. The ebb tidal delta and the north spit areas show more infilling than the flood tidal shoal area. Comparing with Alternatives 1, 2, and 3, similar percentages of sediment back infilled the mining areas. An amount of $3,211 \mathrm{~m}^{3}(4,200 \mathrm{cu}$ yd) of material (2.1\% of original placed $152,900 \mathrm{~m}^{3}$ [200,000 cu yd] of sand) eroded and moved shoreward from the Salisbury placement zone. The percentage of erosion within the Salisbury placement zone is comparable to those in Alternatives 1, 2, 3, and 4. Figure 70 shows erosion on seaward side and deposition on shoreward side around the Newburyport and Newbury placement areas. Net 764 and $6957 \mathrm{~m}^{3}$ (1,000 and 9,100 cu yd) of material (2.0\% and $2.6 \%$ of original placed 38,225 and $267,575 \mathrm{~m}^{3}$ [50,000 and 350,000 cu yd] of sand) eroded in the two placement areas, respectively.

Figure 70. Simulated resulting morphology changes for Alternative 5.

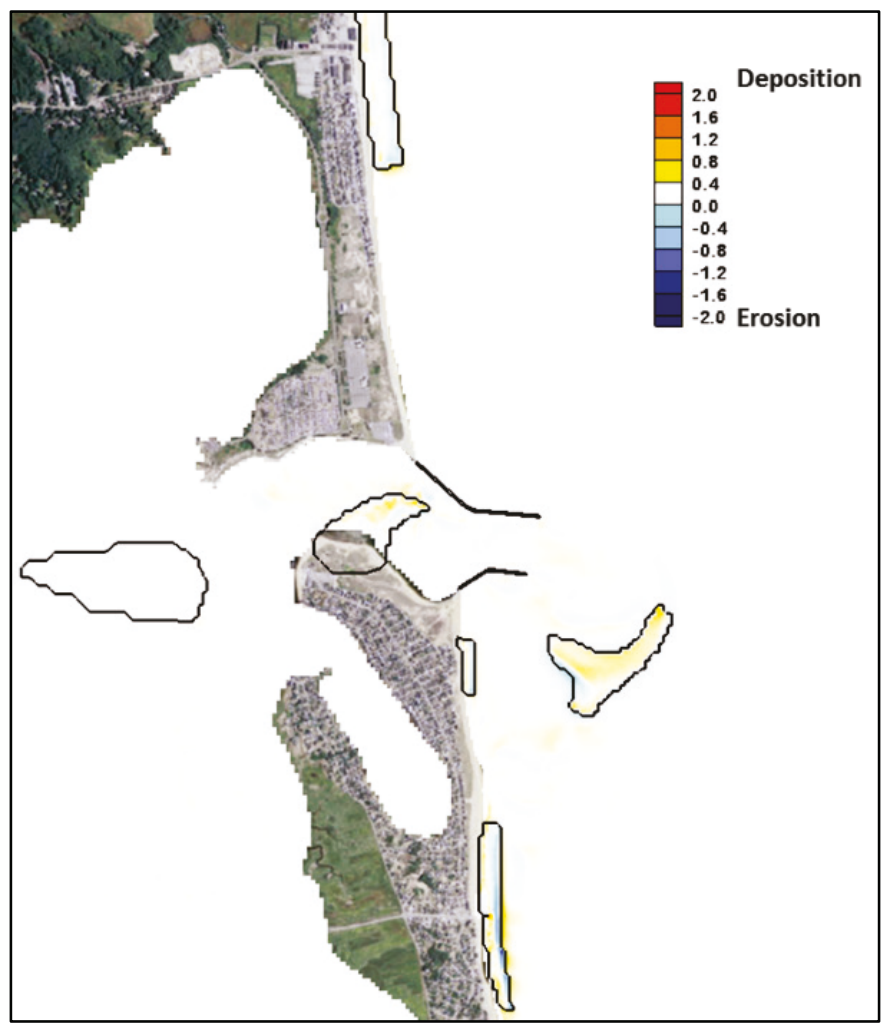




\section{Sedimentation Basin, Alternative 6 (1 Month)}

The sedimentation basin was constructed with a capacity of $229,000 \mathrm{~m}^{3}$ (300,000 cu yd) inside the South Jetty. It is expected to trap sediment material over a simulation period. However, both the model results and the ADCP measurements show weak tidal currents over the basin area because its location is off the main channel and is in the lee side of the South Jetty. Corresponding to weak currents and low sediment mobility, Figure 71 shows minor morphology changes comparing with the base condition, and the amount of sediment infilling is only $76 \mathrm{~m}^{3}$ (100 cu yd) after 1 winter month simulation.

Figure 71. Simulated resulting morphology changes for Alternative 6.

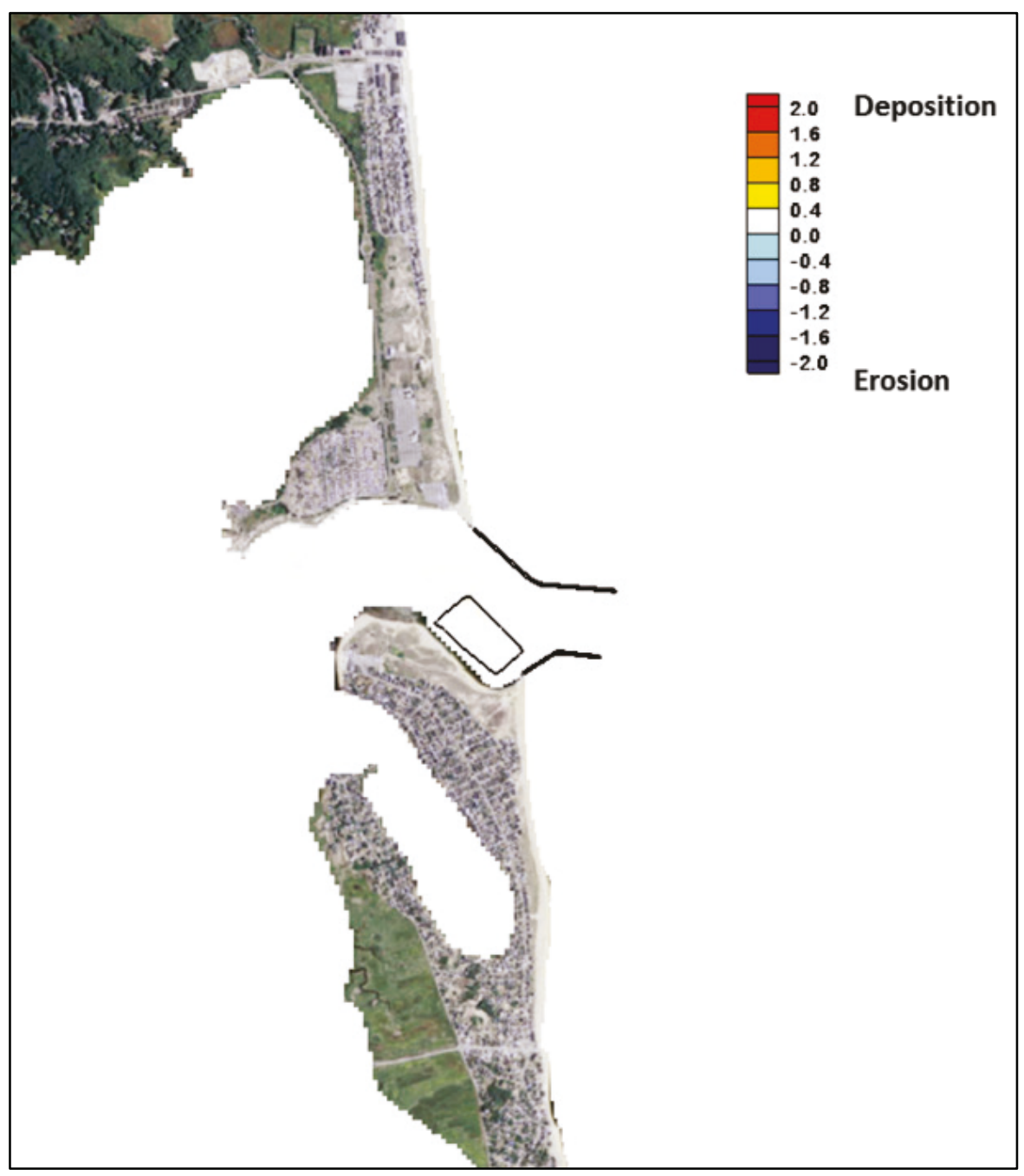




\subsubsection{Structure modification alternatives}

Jetty Removal, Alternative 7 (1 Month)

In this alternative, two jetties are completely removed. Without the protection of jetties, sediment material is quickly filling into the navigation channel. Erosion occurs near the ebb tidal delta and in the shallow area of the original North Jetty location. Comparing with the base condition, 13,455 more $\mathrm{m}^{3}(17,600 \mathrm{cu} \mathrm{yd})$ of sediment filled in the channel area, and 11,468 more $\mathrm{m}^{3}(15,000 \mathrm{cu} \mathrm{yd})$ of sand eroded in the ebb tidal delta area (Figure 72).

Figure 72. Simulated resulting morphology changes for Alternative 7.

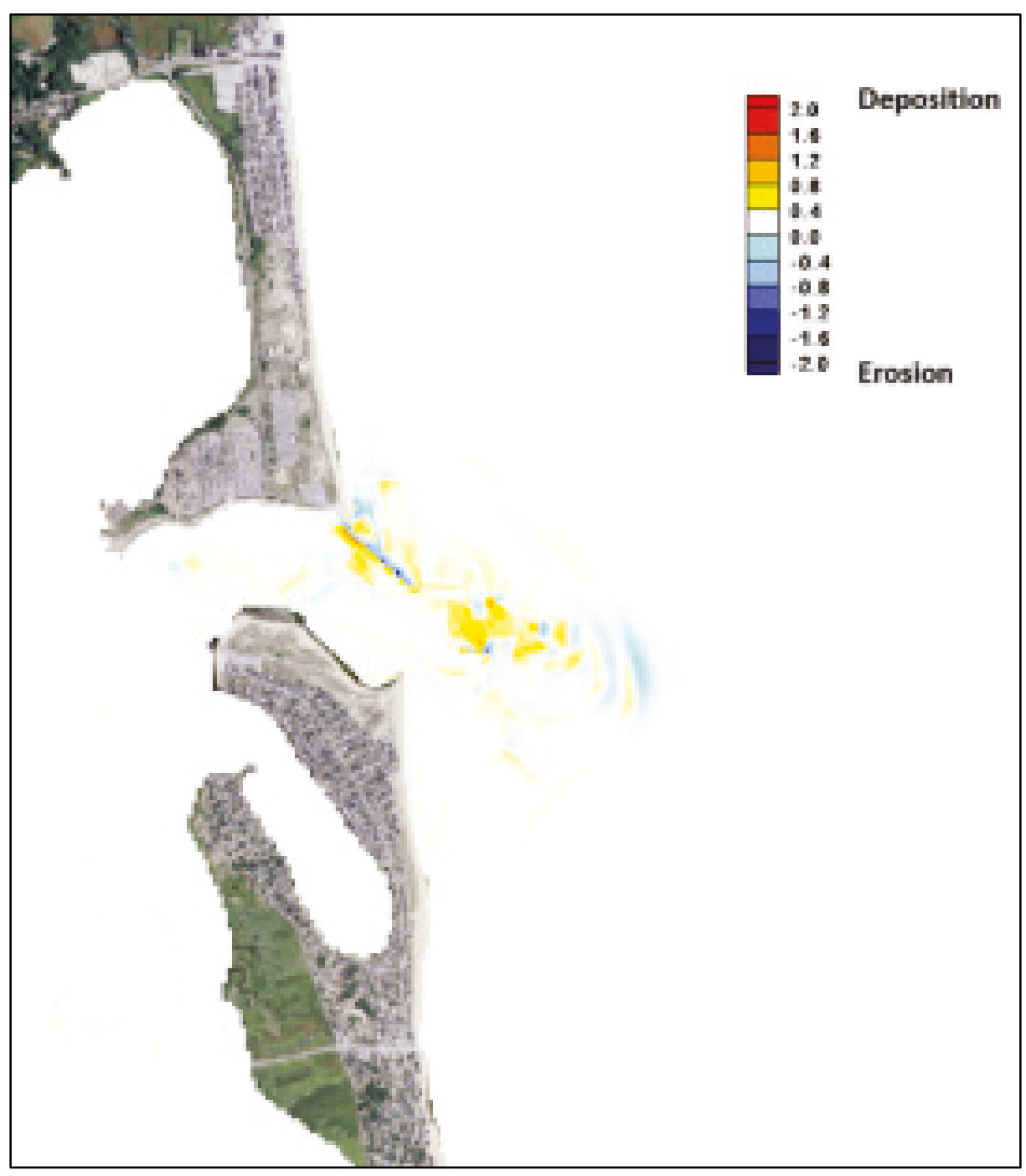




\section{Lengthen Jetties by $500 \mathrm{ft}$, Alternative 8 ( 1 Month)}

The morphology changes shown in Figure 73 indicates that extending both jetties in the offshore direction results in more sediment activity at the new inlet entrance location. Comparing with the base condition, 3,440 more $\mathrm{m}^{3}$ $(4,500 \mathrm{cu} y d)$ of sediment filled in the channel area, and 6,422 more $\mathrm{m}^{3}$ $(8,400 \mathrm{cu} y d)$ of sand eroded in the ebb tidal delta area. From Figure 73 it can be seen that more erosion occurs at the inlet entrance and deposition occurs in the channel and near the ebb tidal delta.

Figure 73. Simulated resulting morphology changes for Alternative 8.

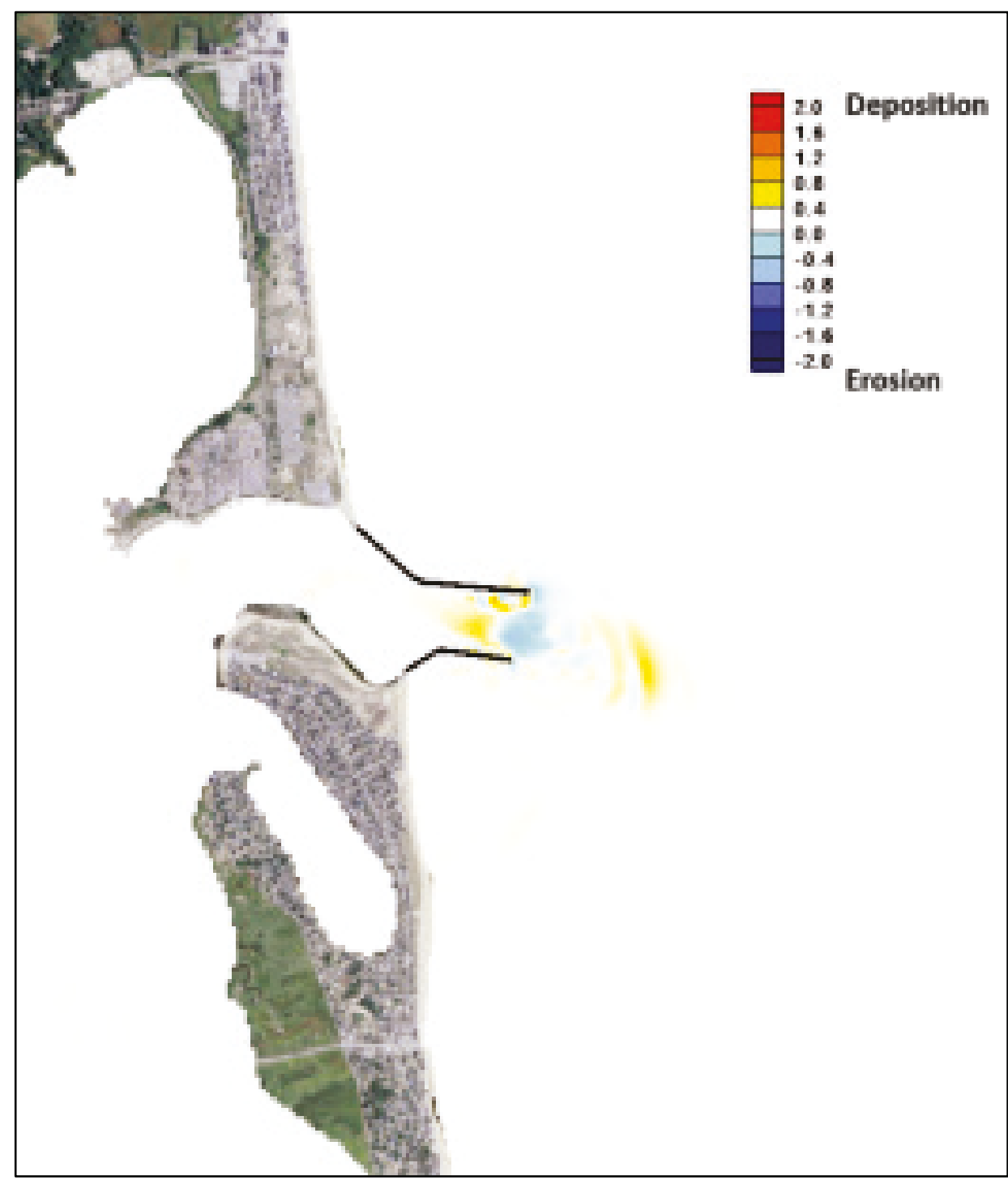




\section{$\underline{\text { Shorten Jetties, Alternative } 9 \text { (1 Month) }}$}

Similar to Alternative 7, shortening jetties removes the protection for the inlet channel and results in sediment accumulation in the channel. As shown in Figure 74, relative to the base condition 7,263 more m3 $(9,500 \mathrm{cu} y d)$ of sediment accreted in the channel area, and 4,052 $\mathrm{m}^{3}$ $(5,300 \mathrm{cu} y d)$ of sediment eroded in the ebb delta area. Figure 74 also shows that most of channel infilling occurs around the inlet entrance. Therefore, the partial jetty removal does not induce as much sediment activity as the alternative of the entire jetty removal.

Figure 74. Simulated resulting morphology changes for Alternative 9.

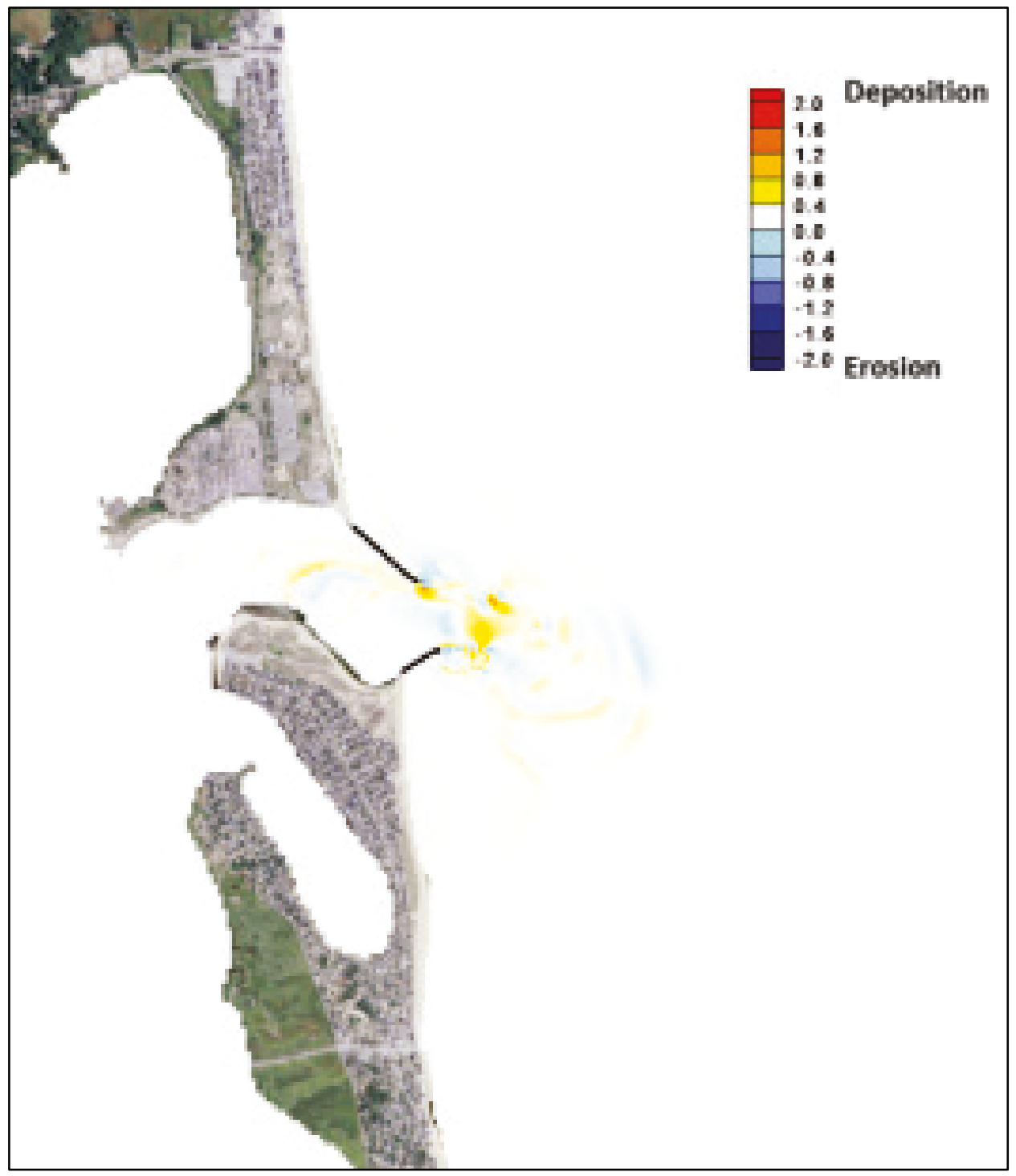




\section{$\underline{\text { Reorient Jetties, Alternative } 10 \text { (1 Month) }}$}

Reorienting jetties to match the alignment of the navigation channel strengthens the along-channel current. Associated with the strong alongchannel current, Figure 75 shows that the reoriented channel experiences large scouring, especially around the inlet entrance, and by lengthening jetties, strong current carries more sand farther offshore. Comparing with the base condition, 153 more $\mathrm{m}^{3}$ (200 $\mathrm{cu} \mathrm{yd}$ ) of sediment eroded in the channel area, and 4,893 more $\mathrm{m}^{3}(6,400 \mathrm{cu} \mathrm{yd})$ of sand accreted in the ebb tidal delta area.

Figure 75. Simulated resulting morphology changes for Alternative 10.

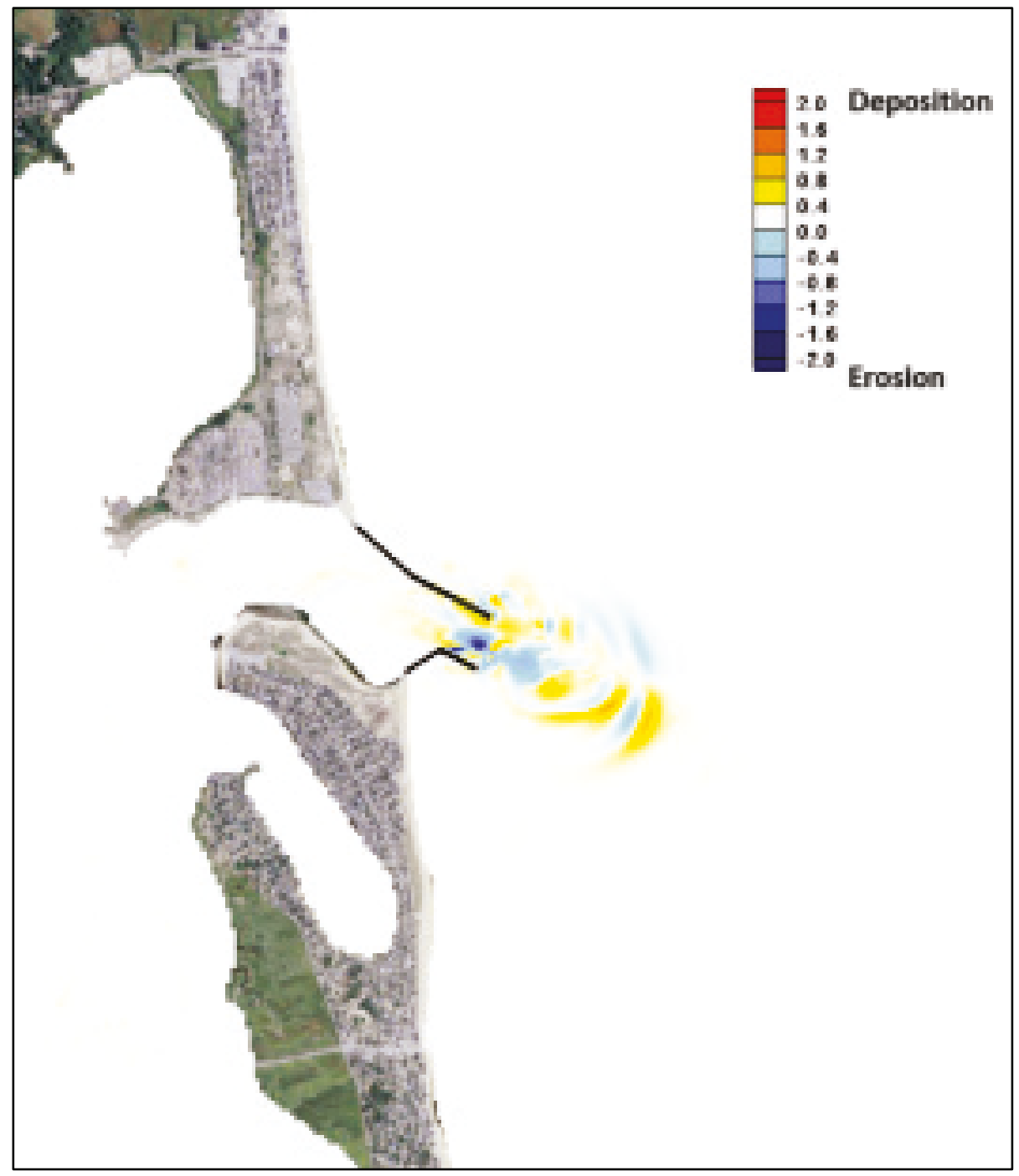




\section{Dogleg on North Jetty, Alternative 11 (1 Month)}

Adding a $152 \mathrm{~m}$ (500 ft) length dogleg oriented towards the southeast modifies the magnitude and direction of along-channel current. The channel current is not as strong as that in Alternative 10 but is strong enough to result in scouring around the inlet entrance. Figure 76 shows the updated morphology change pattern at the inlet entrance and near the ebb tidal delta. Comparing with the base condition, 1,070 more $\mathrm{m}^{3}$ $\left(1,400\right.$ cu yd) of sediment accreted in the channel area, and 5,352 more $\mathrm{m}^{3}$ $(7,000 \mathrm{cu} y d)$ of sand eroded in the ebb tidal delta area.

Figure 76. Simulated resulting morphology changes for Alternative 11.

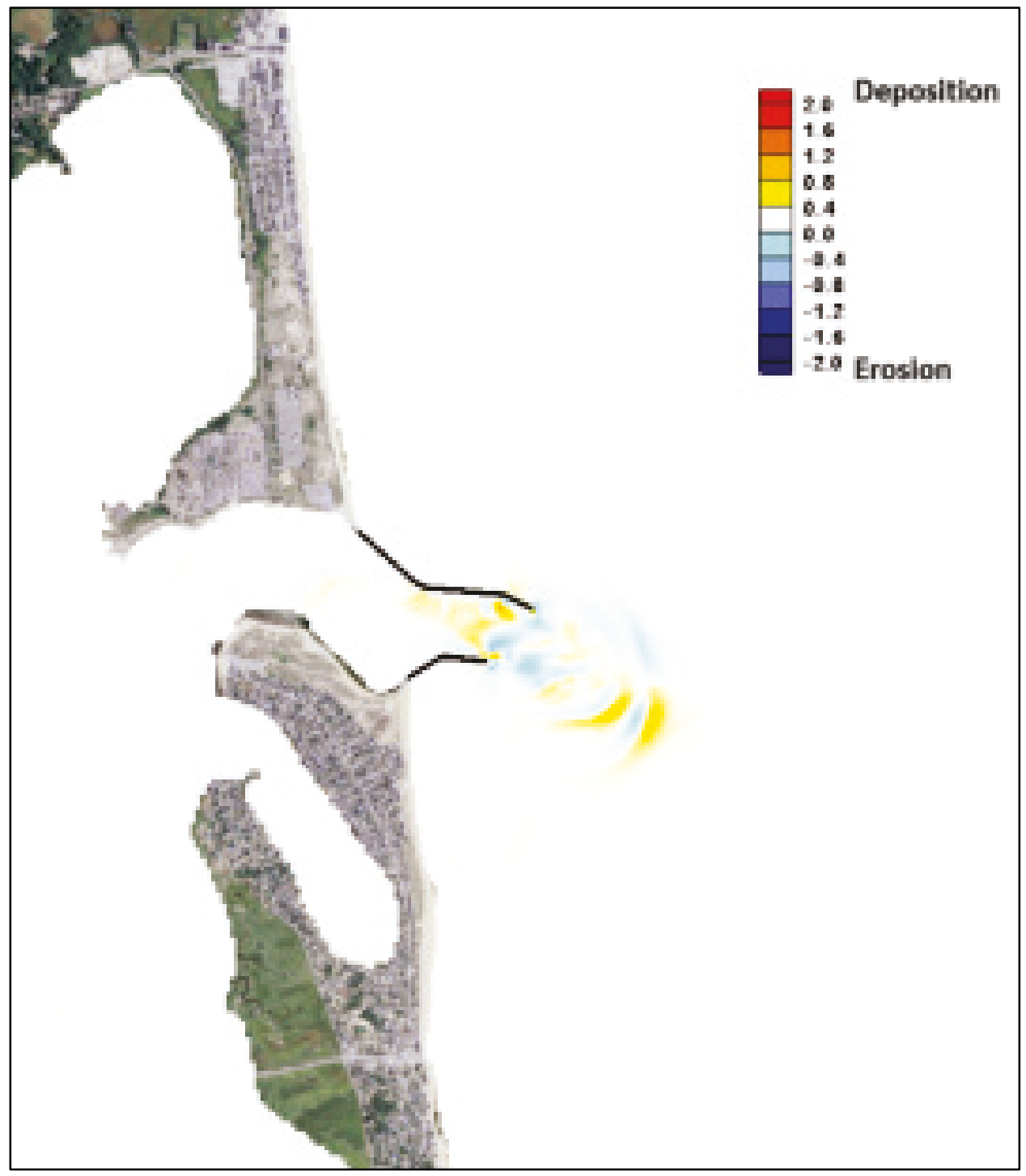




\section{Doglegs on Jetties, Alternative 12 (1 Month)}

Doglegs were added to both of the jetties, and the morphology change pattern is similar to that of Alternative 11 (Figure 77). The dogleg to the South Jetty limits the flow spreading to the south. Total sediment activity is weaker comparing with Alternative 11. Relative to the base condition, $3,593 \mathrm{~m}^{3}$ (4,700 cu yd) of sediment accreted in the channel area, and 10,244 more $\mathrm{m}^{3}(13,400 \mathrm{cu} \mathrm{yd})$ of sand eroded in the ebb tidal delta area.

Figure 77. Simulated resulting morphology changes for Alternative 12.

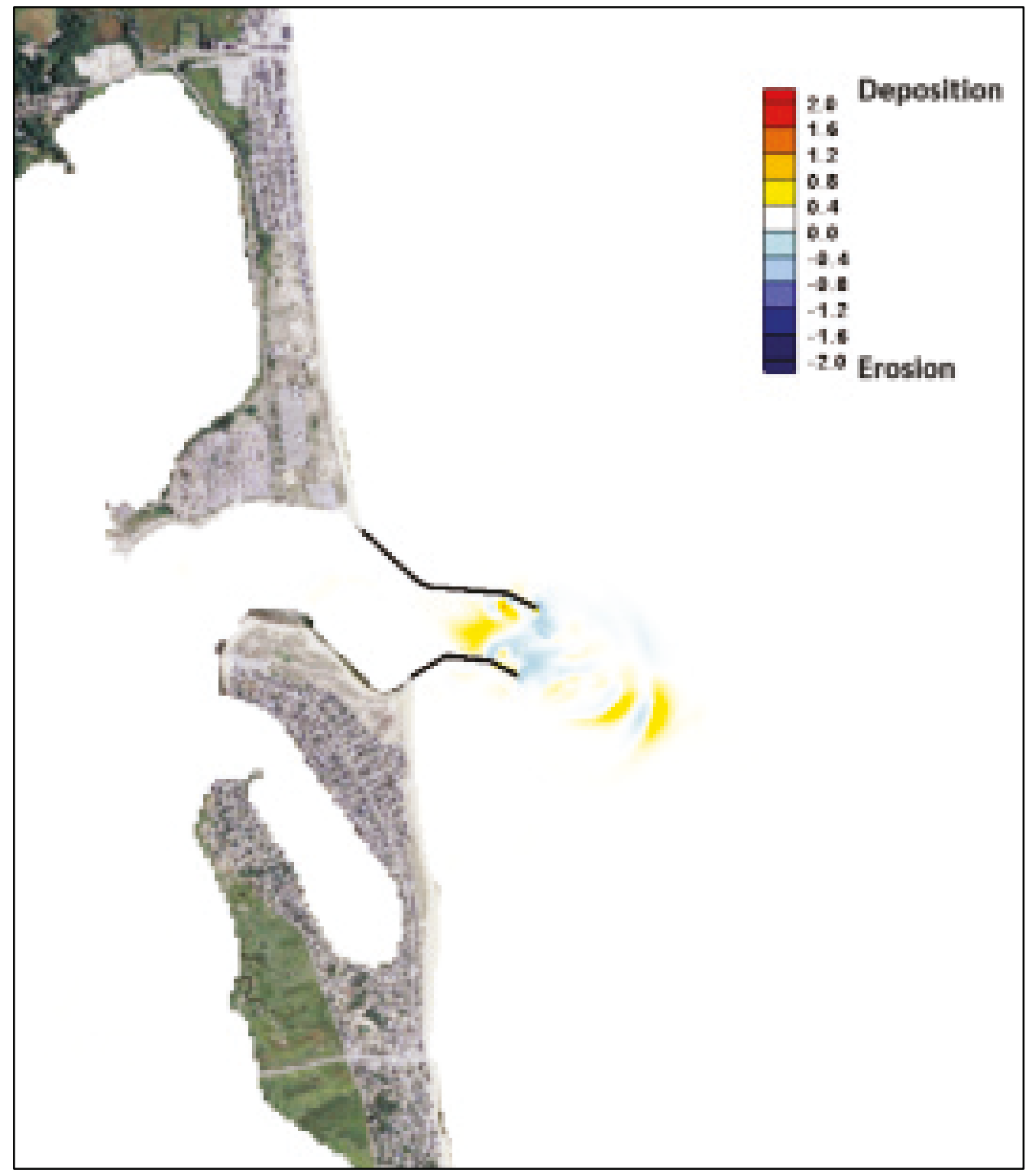


Spur Inside North Jetty, Alternative 13, and Spur Outside South Jetty, Alternative 14 (1 Month)

For Alternative 13, a spur added to the inside North Jetty narrows the inlet channel and results in stronger current and more erosion in the channel near the spur (Figure 78). The stronger current also affects but with limited impact on the tidal delta area. Comparing with the base condition, 6,804 more $^{3} 3(8,900 \mathrm{cu} y d)$ of sediment eroded in the channel area, and 5,810 more $\mathrm{m}^{3}$ ( 7,600 cu yd) of sand accreted in the ebb tidal delta area. For Alternative 14, the spur was added south of the South Jetty, where the current is weak, and no significant morphology change can be seen (Figure 79).

Figure 78. Simulated resulting morphology changes for Alternative 13.

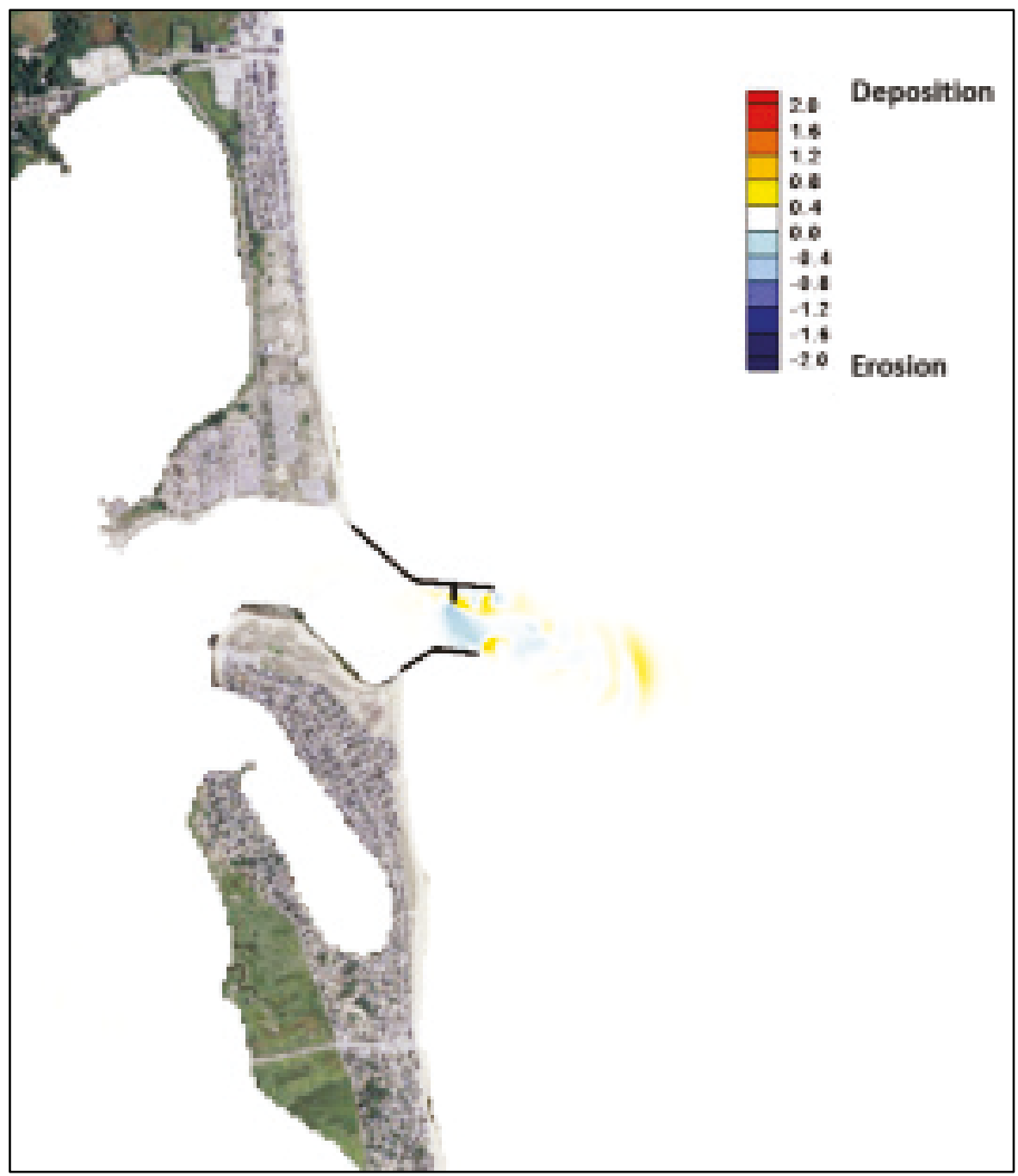


Figure 79. Simulated resulting morphology changes for Alternative 14.

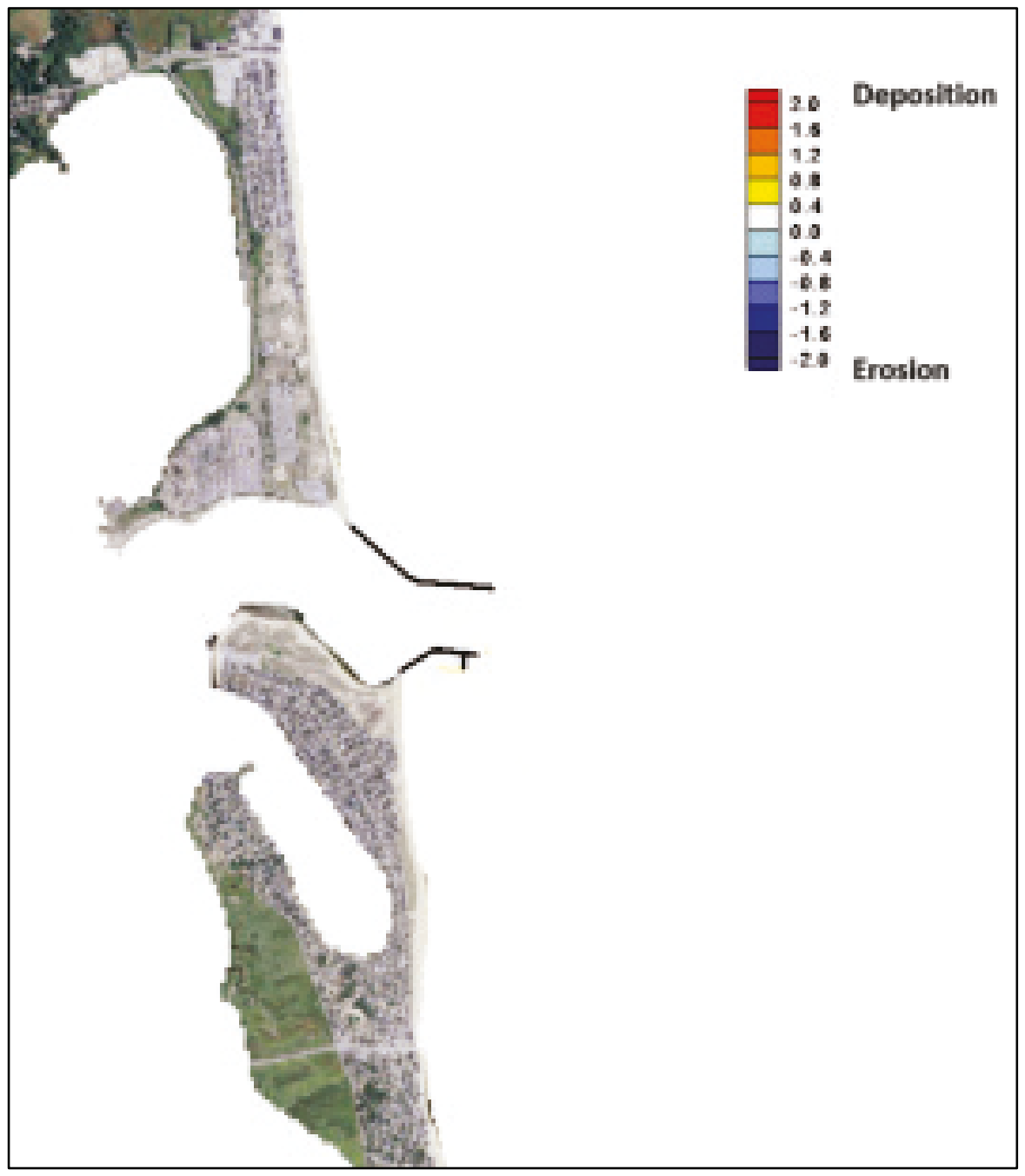

Detached Breakwaters Offshore of Plum Island, Alternative 15 (1 Month)

The intention of building detached breakwaters is to protect the shoreline on the lee side of them. Figure 80 shows four detached breakwaters south of the South Jetty. For the analysis, two polygons were drawn in the figure, one being the area in front of Plum Island Beach and the other the area between the breakwaters and the Plum Island Beach area. Due to stronger tidal current related to the detached breakwaters, erosion occurs in the area between the breakwaters and the Plum Island Beach area. Comparing with the base condition, 841 more $\mathrm{m}^{3}$ (1,100 cu yd) of sediment accreted in the Plum Island Beach area, and 535 more $\mathrm{m}^{3}$ (700 $\mathrm{cu} \mathrm{yd}$ ) of sand eroded in the lee side of the breakwaters. 
Figure 80. Simulated resulting morphology changes for Alternative 15.

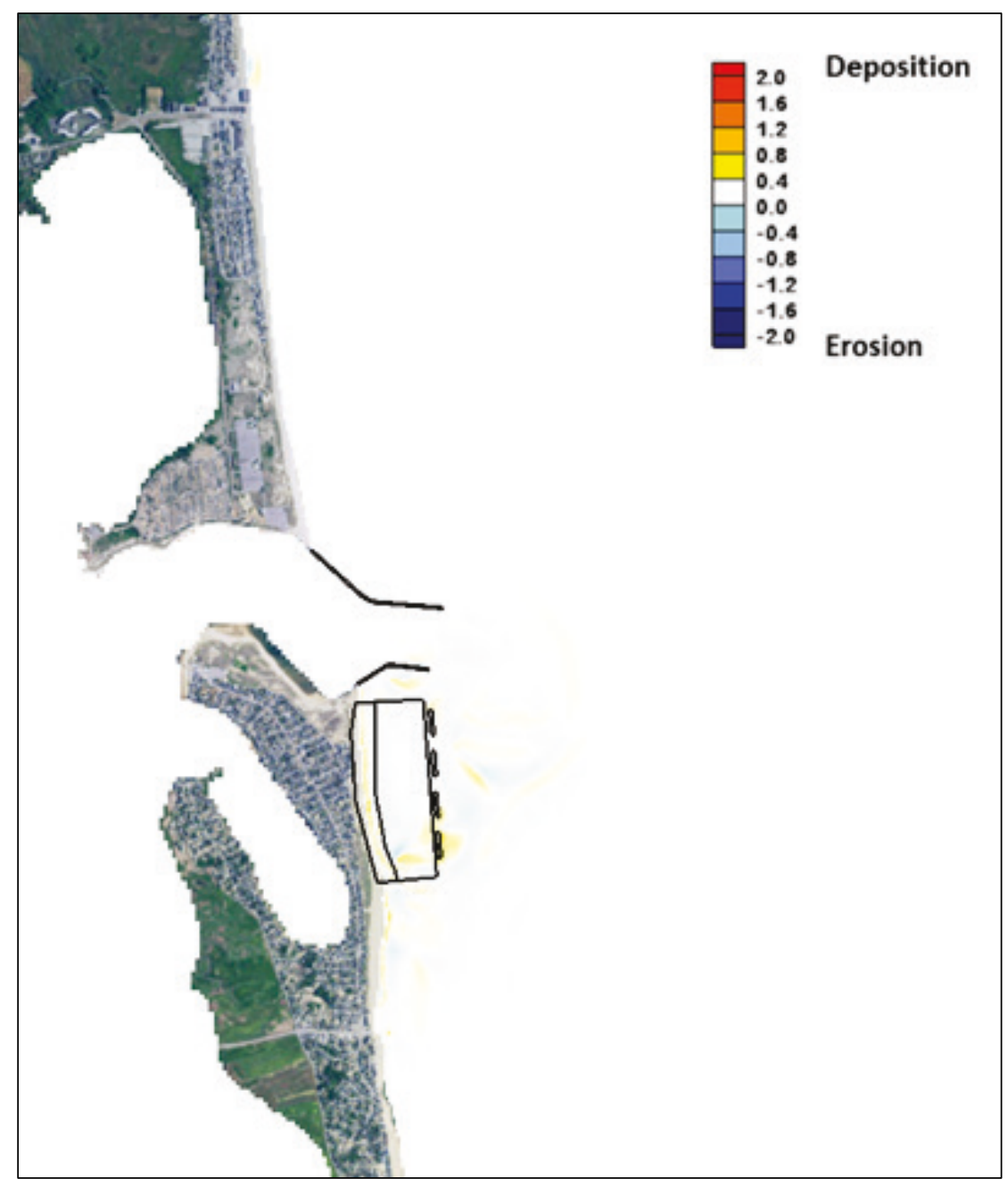

\subsubsection{6-month simulations of selected alternatives}

In the Phase I study, six alternatives were run for a 6-month period spanning from January to June 2011. The analysis was performed by comparing morphology changes between different alternatives after 6-month simulations. The comparison was also conducted for the same alternative between 1-month and 6-month simulations.

\section{Flood Delta Mining Alternative 2 (6 months)}

The flood shoal mining area is off the navigation channel and does not show much morphology change even after the 6-month simulation (Figure 81). Comparing with the base condition, approximately 1,453 more $\mathrm{m}^{3}(1,900 \mathrm{cu}$ yd) of sediment (o.4\% of mined $383,250 \mathrm{~m}^{3}$ [500,000 cu yd] of sediment) filled in the mined area. As shown in Figure 81, erosion occurs in the 
offshore area, and accretion occurs in the nearshore area within the three placement locations. Relative to the base condition, 7,874 $\mathrm{m}^{3}$ (10,300 cu yd) of placed material (10.3\% of original placed $76,450 \mathrm{~m}^{3}(100,000 \mathrm{cu} \mathrm{yd})$ of sand) eroded from the Salisbury placement zone. The amounts of 5,734 and $34,173 \mathrm{~m}^{3}$ (7,500 and 44,700cu yd) of placed material (15.0\% and $12.8 \%$ of original placed 38,225 and $267,575 \mathrm{~m}^{3}$ [50,000 and 350,000 cu yd] of sand) eroded in the Newburyport and Newbury placement zones. The three placement zones all show a similar percentagewise net erosion of placed sediment material (between 10\% to 15\%).

Figure 81. Simulated difference in morphology change between Alternative 2 and base condition for 6-month simulation.

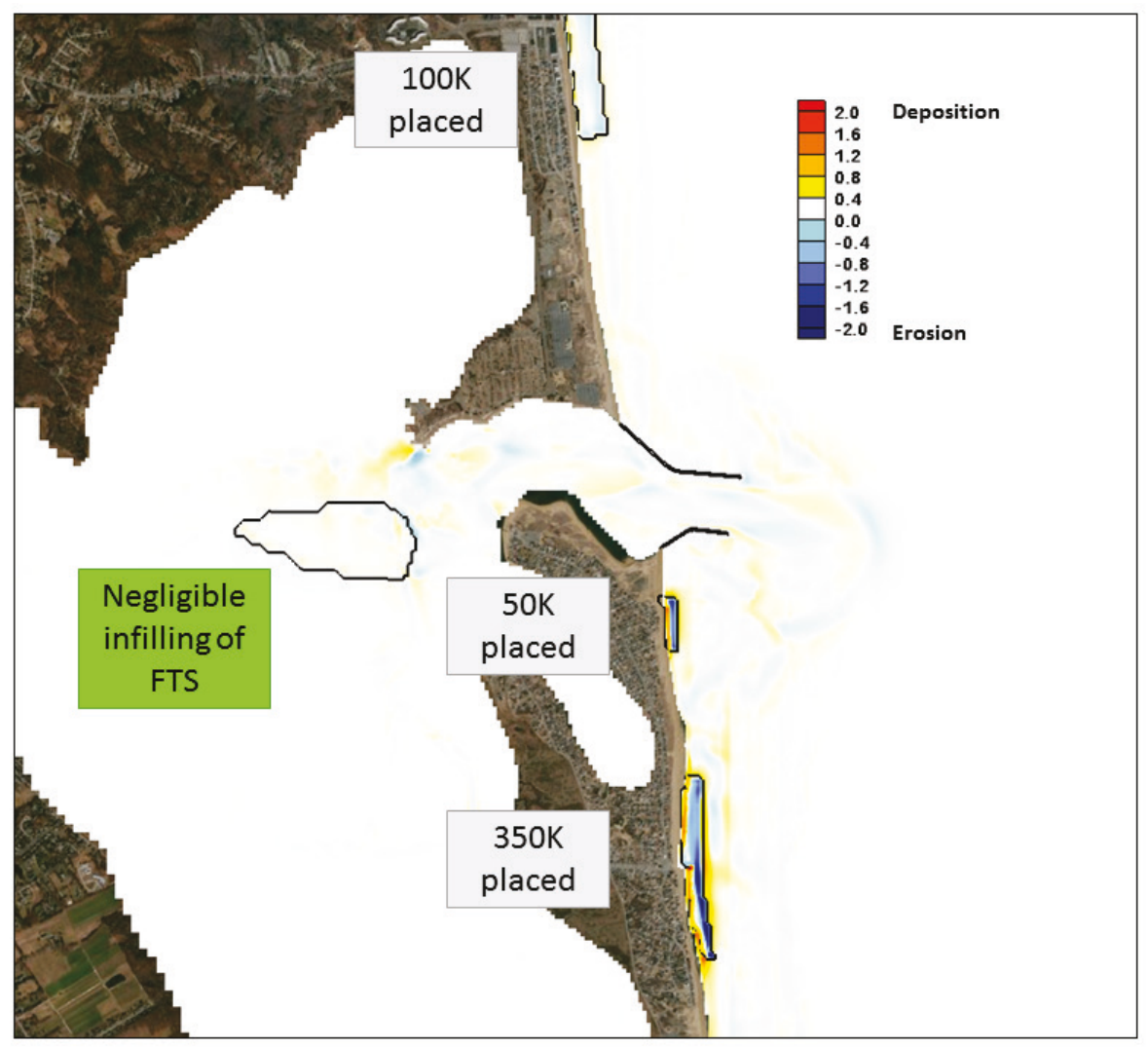

Modified North Point, Plum Island Mining, Alternative $3 \mathrm{~b}$ (6 months)

In this alternative, the total amount of mining and placement was reduced from $383,250 \mathrm{~m}^{3}$ (500,000 cy yd) of Alternative 3 to $286,688 \mathrm{~m}^{3}$ (375,000 cu yd). The placement in the Salisbury and the Newburyport zones is the same as in Alternative 3, and only the placement in the Newbury zone was reduced from 267,575 to $172,913 \mathrm{~m}^{3}$ (350,000 to 225,000 cu yd). Because the mining area at North Point is very close to the 
inlet channel, tidal current over the site can be large. Therefore, the resulting morphology change shows significant filling in the area (Figure 82). Comparing with the base condition, 77,597 more $\mathrm{m}^{3}$ $(101,500 \mathrm{cu} y d)$ of sediment (27.1\% of mined $286,688 \mathrm{~m}^{3}$ (375,000 cu yd) of sediment) filled in the mined area. A small amount of placed material $\left(7,492 \mathrm{~m}^{3}\right.$ [9,800 cu yd], $9.8 \%$ of original placed $76,450 \mathrm{~m}^{3}$ [100,000 cu yd] of sand) eroded in the Salisbury zone. The amounts of 5,429 and 32,874 $\mathrm{m}^{3}$ $(7,100$ and $43,000 \mathrm{cu} y d)$ of placed material (14.2\% and $19.1 \%$ of original placed 38,225 and 172,913 $\mathrm{m}^{3}$ [50,000 and 225,000 cu yd] of sand) eroded and migrated shoreward in the Newburyport and Newbury placement zones, respectively (Figure 82).

Figure 82. Simulated difference in morphology change between Alternative $3 b$ and base condition for 6-month simulation.

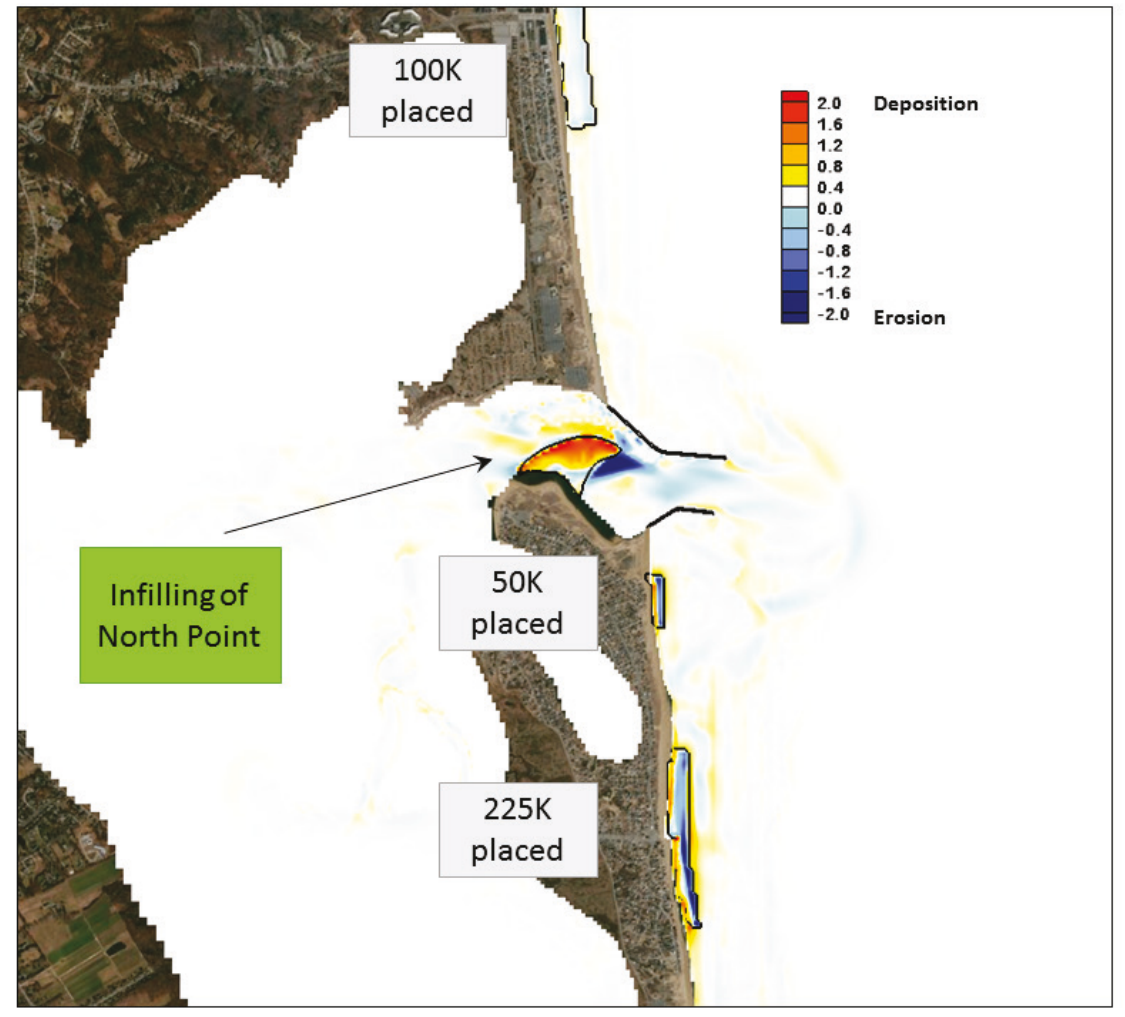

Modified Sedimentation Basin (6 months), Alternative 6b (6 months)

Comparing with Alternative 6, the sedimentation basin here was shifted slightly to the northwest towards the inlet channel inside the South Jetty. Corresponding to strong currents and high sediment mobility, Figure 83 shows significant sediment infilling and morphology changes over the northwest (top left) corner of the basin comparing with the base condition. 
The amount of sediment accumulation in the basin is approximately $25,764 \mathrm{~m}^{3}$ (33,700 cu yd) more than the base case after the 6-month simulation. An amount of 8,792 more $\mathrm{m}^{3}(11,500 \mathrm{cu} \mathrm{yd})$ of placed material (11.5\% of original placed 76,450 $\mathrm{m}^{3}[100,000 \mathrm{cu} \mathrm{yd}]$ of sand) eroded in the Salisbury placement zone. The amounts of 7,951 and 47,093 $\mathrm{m}^{3}$ (10,400 and $61,600 \mathrm{cu} y d)$ of placed material (20.8\% and $41.1 \%$ of original placed 38,225 and 114,675 $\mathrm{m}^{3}$ [50,000 and 150,000 cu yd] of sand) eroded in the Newburyport and Newbury placement zones, respectively.

Figure 83. Simulated difference in morphology change between Alternative $6 \mathrm{~b}$ and base condition for 6-month simulation.

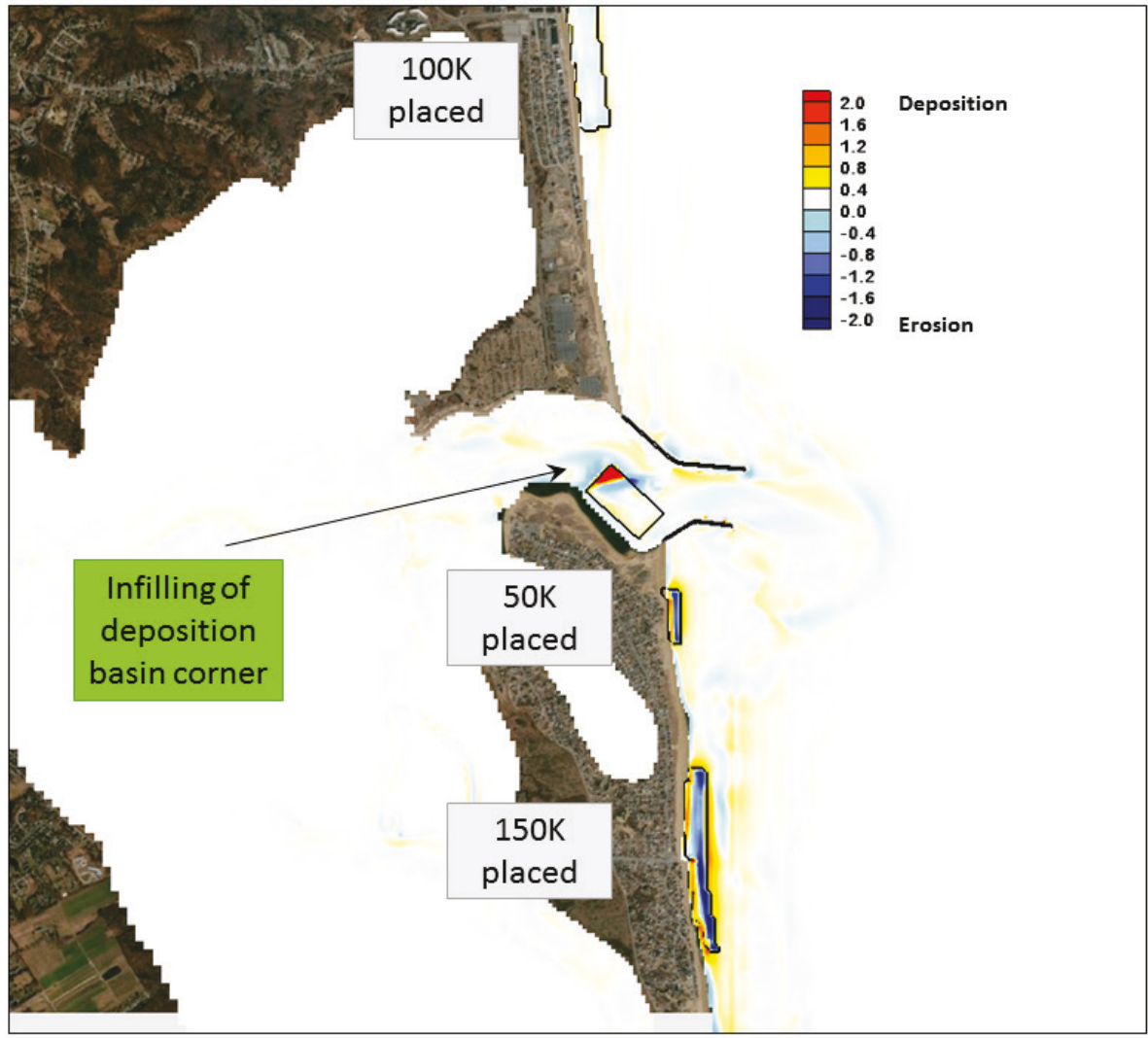

Shorten Jetties (6 months), Alternative 9 (6 months)

Comparing the 6-month with the 1-month simulation for this alternative, it can be seen that the morphology change pattern is similar and the longer term simulation corresponds to more erosion and accretion at the inlet entrance and near the ebb tidal delta (Figure 74 and Figure 84). Relative to the base condition, 20,565 more $\mathrm{m}^{3}(26,900 \mathrm{cu} \mathrm{yd})$ of sediment is accreted in the channel area, and 7,110 $\mathrm{m}^{3}$ (9,300 $\left.\mathrm{cu} \mathrm{yd}\right)$ of sediment eroded in the ebb delta area. Most of channel infilling occurs outside of the jetties where a new ebb tidal delta forms. 
Figure 84. Simulated difference in morphology change between Alternative 9 and base condition for 6-month simulation.

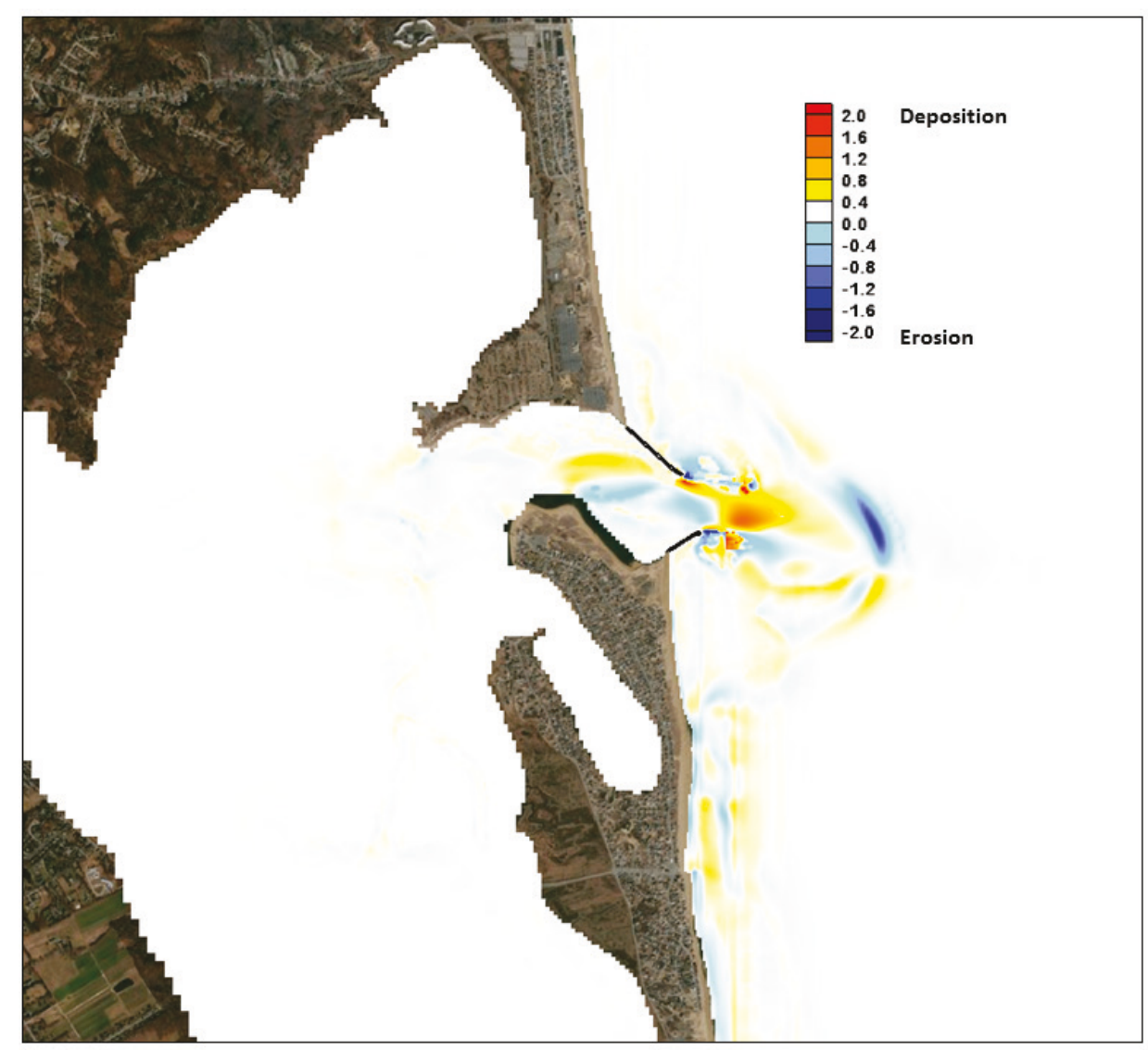

Modified Detached Breakwaters (6 months), Alternative 15b (6 months)

Comparing with the base condition, the nearshore area between the top (northern) four detached breakwaters and the shoreline shows 4,816 $\mathrm{m}^{3}$ $(6,300 \mathrm{cu} y d)$ less sand accretion, and the area between the bottom (southern) four detached breakwaters and the shoreline show $2,982 \mathrm{~m}^{3}$ (3,900 cu yd) less sand erosion during the 6-month simulation (Figure 85). Under the protection of the detached breakwaters, more sand accretion can be observed in the lee side of the bottom four breakwaters. Erosion occurs in the area between the breakwaters and the Plum Island Beach area due to stronger tidal current related to the detached breakwaters. Without detached breakwaters, more erosion occurs along the shoreline of Plum Island. 
Figure 85. Simulated difference in morphology change between Alternative $15 \mathrm{~b}$ and base condition for 6-month simulation.

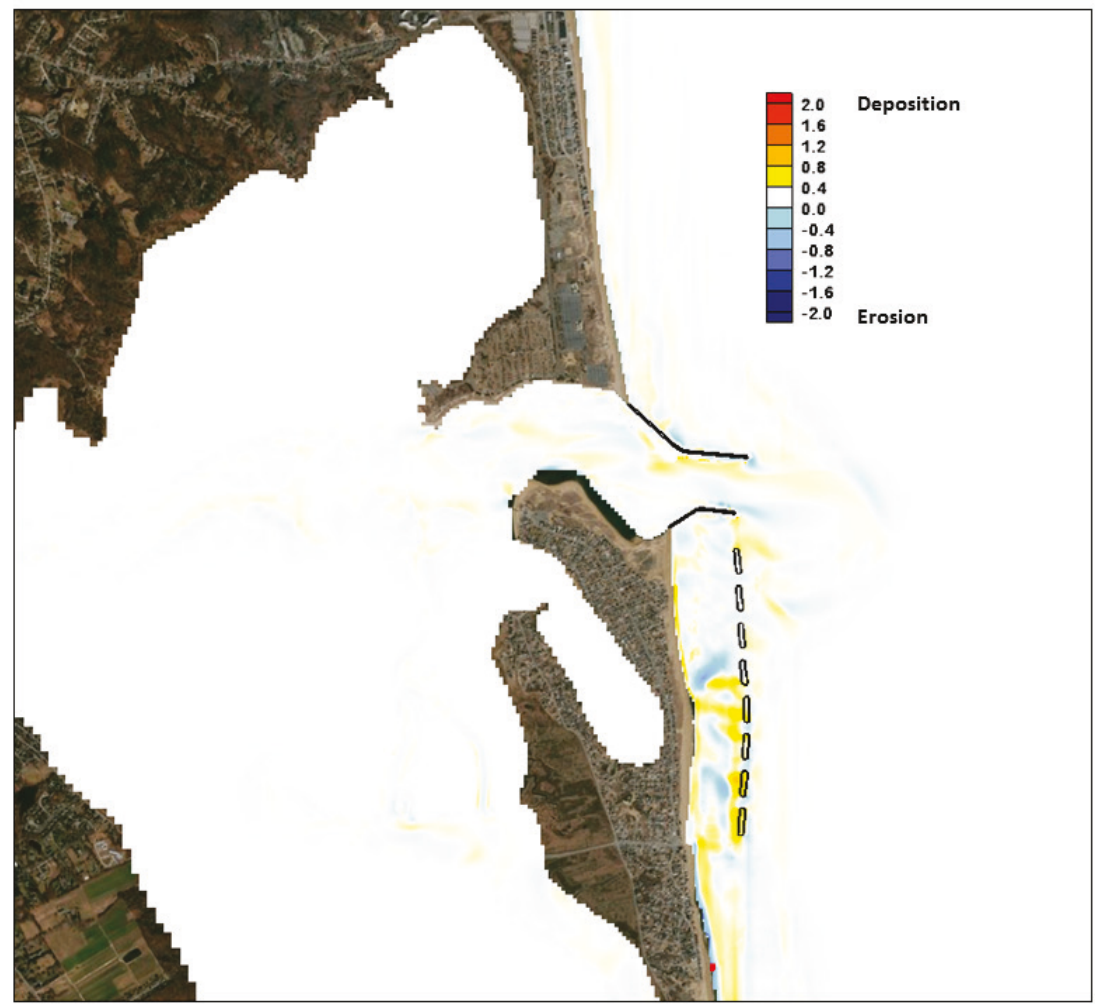

Modified Detached Breakwaters and Modified Sedimentation Basin Mining (6 months), Alternative 15c (6 months)

This alternative is the combination of Alternative $6 \mathrm{~b}$ and Alternative $15 \mathrm{~b}$ in which the sediment basin within the inlet and the placement sites in front of Plum Island Beach are mostly influenced (Figure 86). Consistent with the findings in Alternative 6b, significant sediment infilling and morphology changes are observed over the northwest (top left) corner of the basin comparing with the base condition. The amount of sediment accumulation in the basin is approximately $25,305 \mathrm{~m}^{3}$ (33,100 cu yd) more than the base case after the 6-month simulation. An amount of 7,951 more $\mathrm{m}^{3}(10,400 \mathrm{cu} \mathrm{yd})$ of placed material (10.4\% of original placed $76,450 \mathrm{~m}^{3}$ [100,000 cu yd] of sand) eroded in the Salisbury placement zone. Because of the detached breakwaters, the placed material in the lee side of the detached breakwaters is not eroded as much as that in Alternative 6b. Relative to the base case, only 2,064 and 32,033 more $\mathrm{m}^{3}$ (2,700 and $41,900 \mathrm{cu} y d)$ of placed material (5.4\% and $27.9 \%$ of original placed 38,225 and 114,675 $\mathrm{m}^{3}$ [50,000 and 150,000 cu yd] of sand) eroded in the Newburyport and Newbury placement zones, respectively. 
Except for the dissipation of placed material in front of Plum Island, the pattern in morphology changes for this alternative is very similar to that for Alternative 15b surrounding the detached breakwaters.

Figure 86. Simulated difference in morphology change between Alternative $15 \mathrm{c}$ and base condition for 6-month simulation.

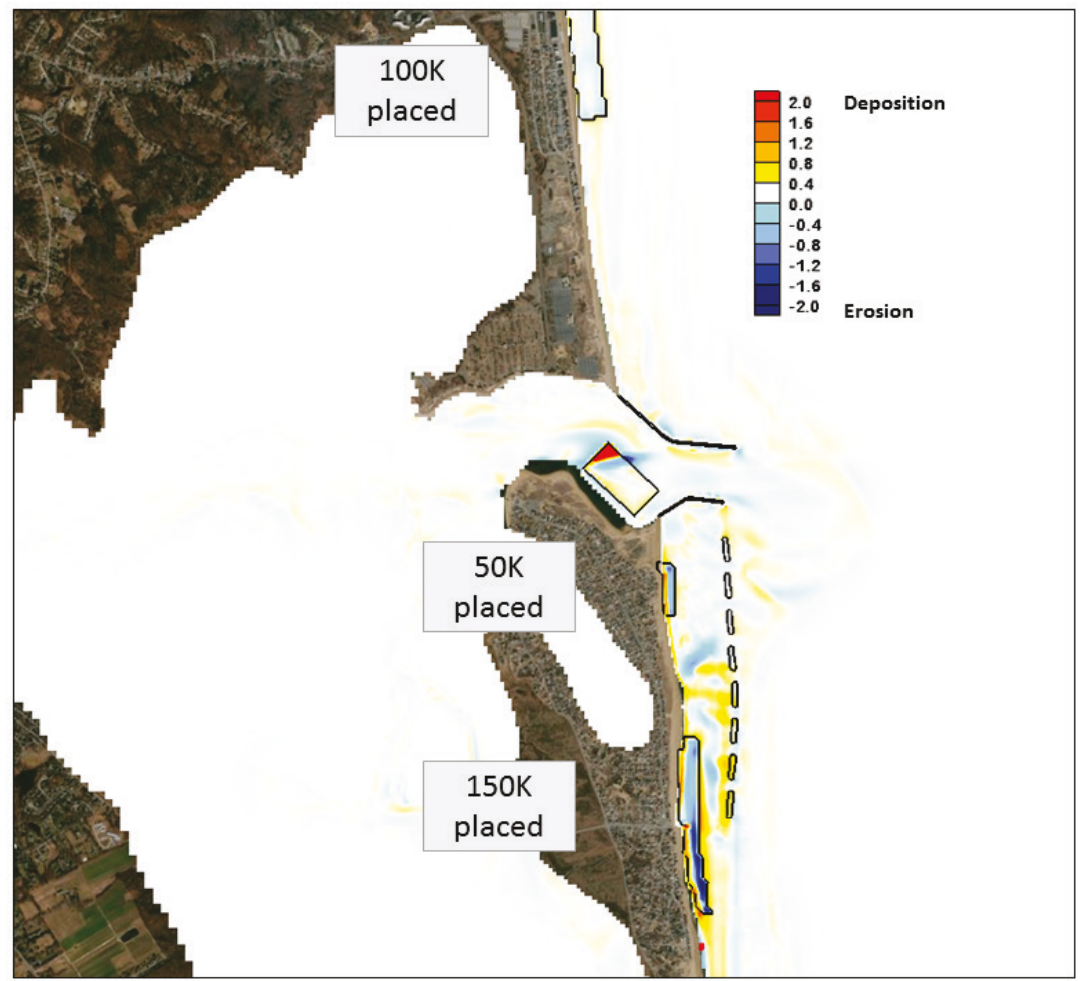

\subsection{Phase II}

\subsubsection{CMS validation}

No hydrodynamic and wave data were available for calibration or validation of the Phase II study. However, a few datasets of bed grain size distribution provided information for setting up a multi-grain size simulation. Based on the datasets, the model setup for the Phase I study was adjusted for the development of the base model grid for the Phase II study.

Corresponding to Figure 54 and Figure 55, Figure 87 and Figure 88 show non-erodible areas and spatial distributions of Manning's $n$ and $D_{50}$ around the inlet. In this setup, only non-erodible areas are located at the jetties and the Badgers Rock. Instead of non-erodible bottom in Phase I, very coarse grain sizes $(7-10 \mathrm{~mm})$ were specified to obtain smooth 
transport and erosion/accretion pattern in the navigation channel. Manning's $n$ ranges from 0.025 to 0.045 . Manning's $n$ of 0.045 was specified for the jetty area, and 0.025 was assigned in the rest of the domain. Multi-grain size sediment transport modeling was conducted in the Phase II study. Referring to the sediment grain size distributions by USGS and NAE (Figure 20), six classes of grain sizes were specified for the transport calculation, which are $0.2,0.5,1.2,2.7,10.0$, and $60.0 \mathrm{~mm}$. The bed grain size distribution $\left(D_{50}\right)$ shows that grain size is very coarse in the channel from the Sound to the ebb tidal shoal. Finer grain size of $0.2 \mathrm{~mm}$ was specified over the ebb tidal shoal and in Salisbury Beach. In the offshore area and in front of Plum Island Beach, medium to coarse grain size dominates (Figure 20 and Figure 88).

Figure 87. Specifications of (a) non-erodible bed and (b) Manning's $n$.

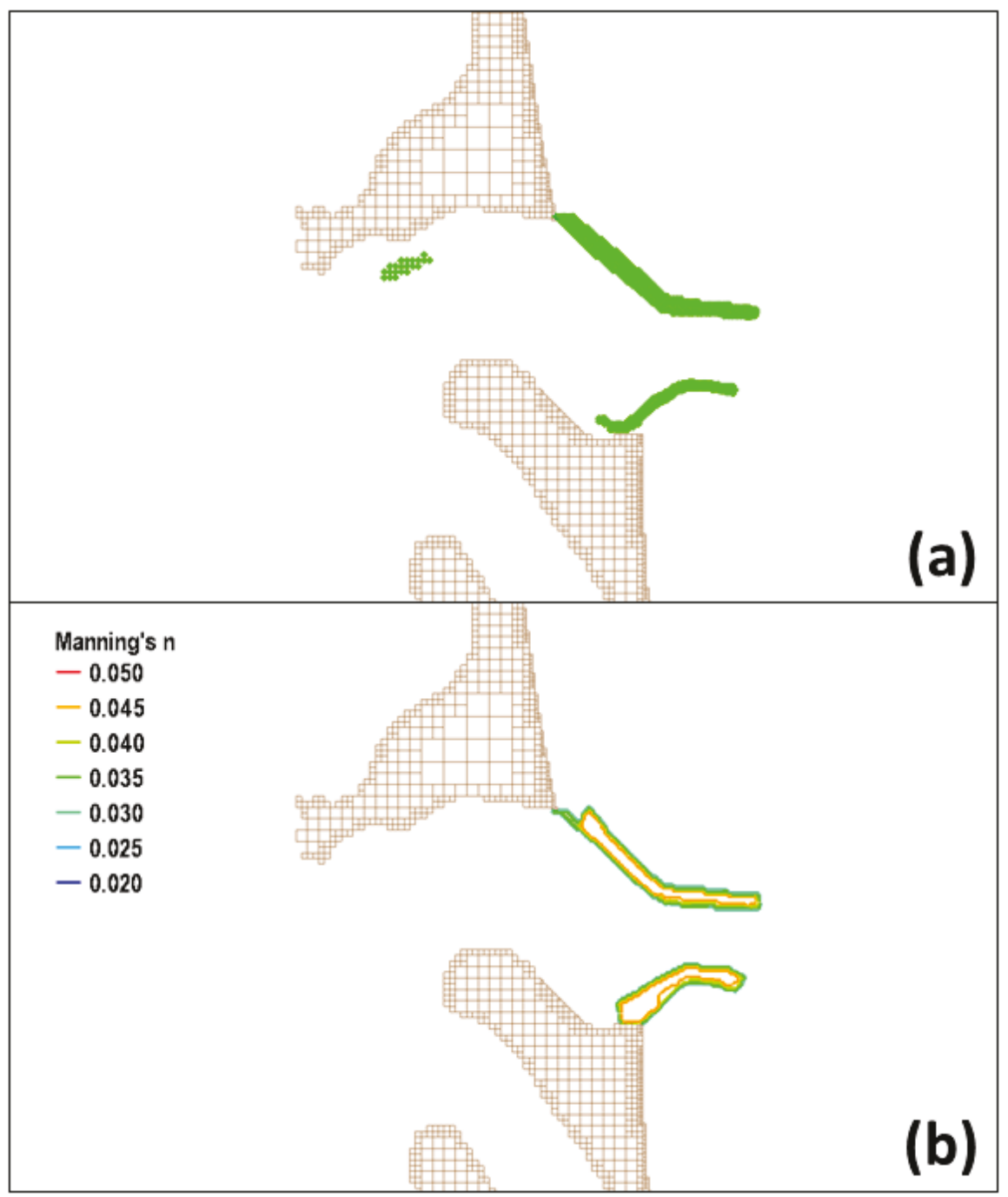


Figure 88. Specifications of bed grain sizes $\left(D_{50}\right)$.

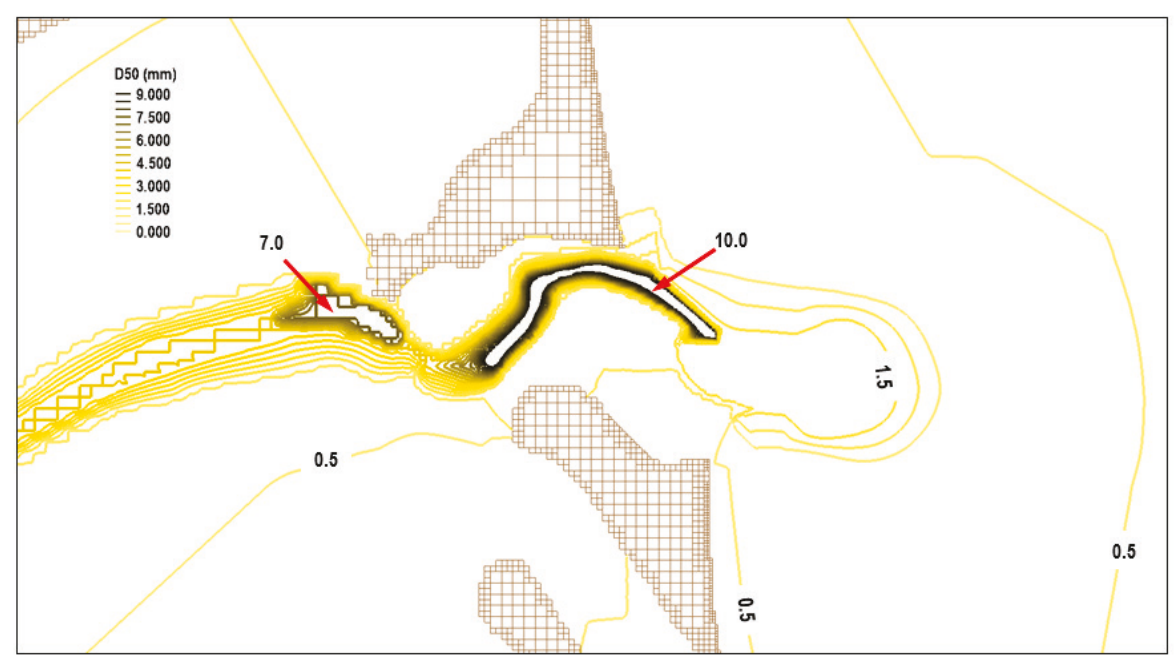

Besides the model parameter adjustment, the model grid was refined surrounding the jetties, the erosion hotspot north of Plum Island within the South Jetty, and the Plum Island Beach. The lidar measurements provided updated bathymetry and were used to validate the CMS calculations in sediment transport and bed volume change for the period of 15 December 2014 to 15 June 2015.

For the CMS validation, the region around Merrimack Inlet was divided into 14 sub-regions covered by the two lidar surveys (Figure 89), which include Salisbury Beach (7), Plum Island Beach $(2,5,12,14)$, ebb shoal (10), navigation channel $(3,6,9)$, Plum Island Sound (1), etc. The calculated bed volume changes were compared with the observations within each sub-region.

Figure 89. 14 sub-regions around Merrimack Inlet.

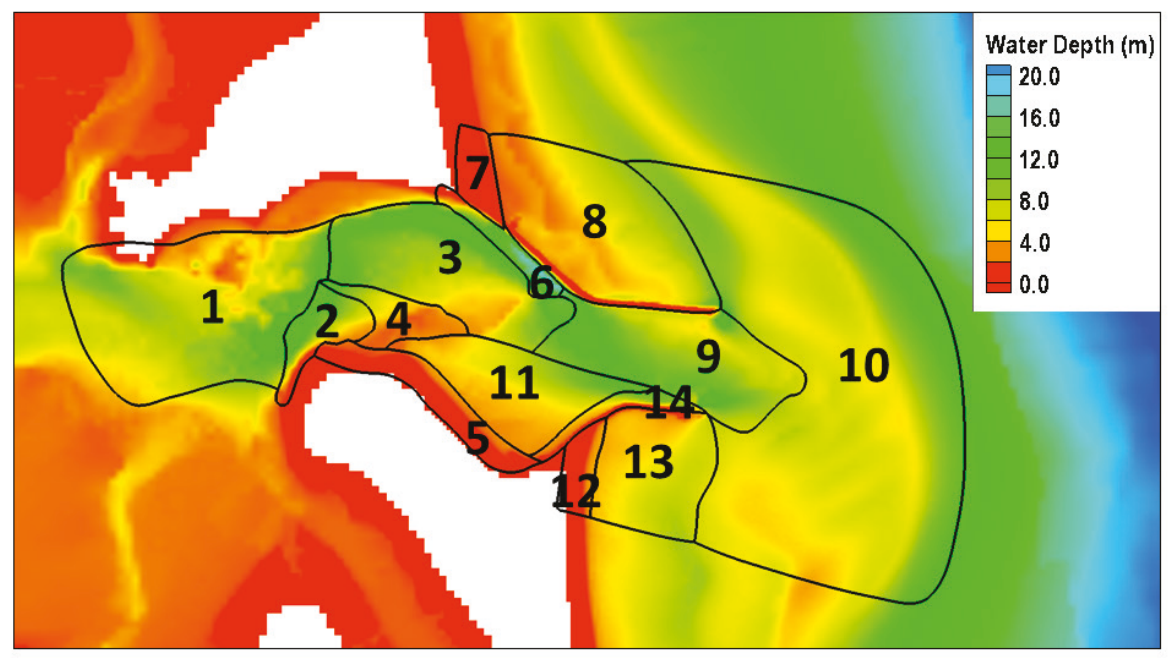


Figure 90 shows the lidar observed morphology change pattern between 15 December 2014 and 27 May 2015. Erosion occurred in front of Salisbury Beach and Plum Island Beach. North of Plum Island within the inlet, land topography had a negative elevation change as much as 4 to $5 \mathrm{~m}$ (13.1 to $16.4 \mathrm{ft}$ ) during the 6-month period and significant shoreline retreat. The shallow shoal referred to as "North Point" had migrated somewhat oceanward, as is illustrated by the erosion near the shoreline and accretion and eastward extension into the navigation channel. Along the navigation channel, the morphology change displays alternate erosion and accretion pattern (e.g., typical inlet throat sand waves). Erosion was dominant across the ebb tidal delta, and accretion occurred in the nearshore, north and south of the ebb delta.

Figure 90. Observed morphology change between 15 December 2014 and 27 May 2015. The coastal outline is the MSL contour. The warm color represents the deposition, and the cold color represents the erosion.

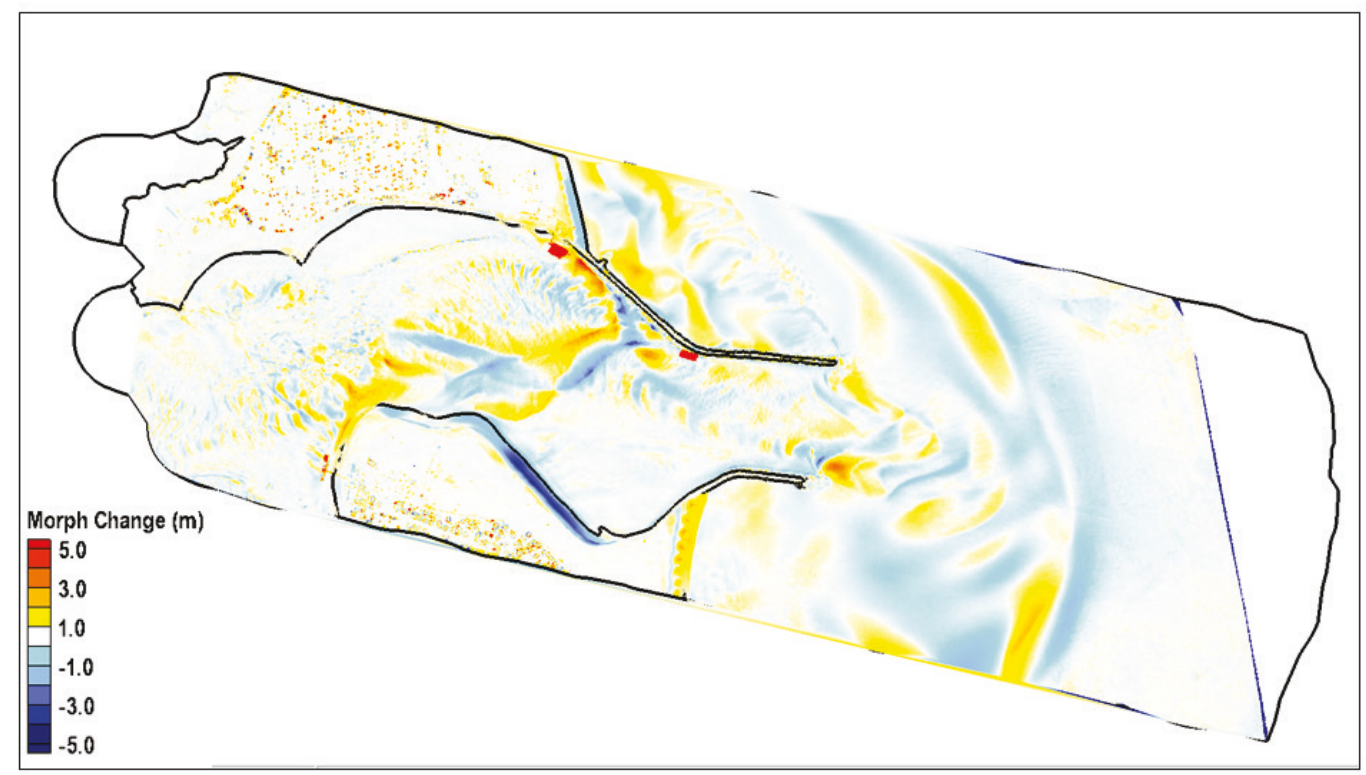

The calculated morphology change results are shown in Figure 91, and the comparison of the 6-month bed volume change in each sub-region is listed Table 3-5. The calculated erosional areas include Salisbury Beach, Plum Island Beach, ebb tidal shoal, inlet throat, and the north of Plum Island adjacent to navigation channel, which is consistent with the lidar-observed results. Although the total bed volume change in the inlet was underestimated, the calculated bed volume changes in 10 sub-regions, out of 14 sub-regions, show the consistent erosion/accretion trend with the measured bed volume changes (Table 3-5). The individual sub-regions and the total bed volume change were within the same order of magnitude. 
Note that the inconsistencies appeared at four sub-regions: sub-regions 1 and 2 around the flood tide shoal and north spit and sub-regions 12 and 13 to the south of the South Jetty. Sub-regions 1 and 2 are located in a confluent area of deep channel and shallow shoal in which large depth gradient would result in great current changes, and any improper specification of initial bathymetry would cause large bias of current and sediment transport calculations. Although both the lidar and the model results show erosion pattern nearshore and around the South Jetty at subregions 12 and 13, the bed volume changes in Table 3-5 indicate that the CMS overestimate the erosion in the area, which could be related to the missing information of grain size distribution surrounding the jetty area.

Figure 91. Simulated morphology change between 15 December 2014 and 15 June 2015. The coastal outline is the MSL contour. The black dashed outline spans the common extent of the 2014 and 2015 lidar surveys. The warm color represents the deposition, and the cold color represents the erosion.

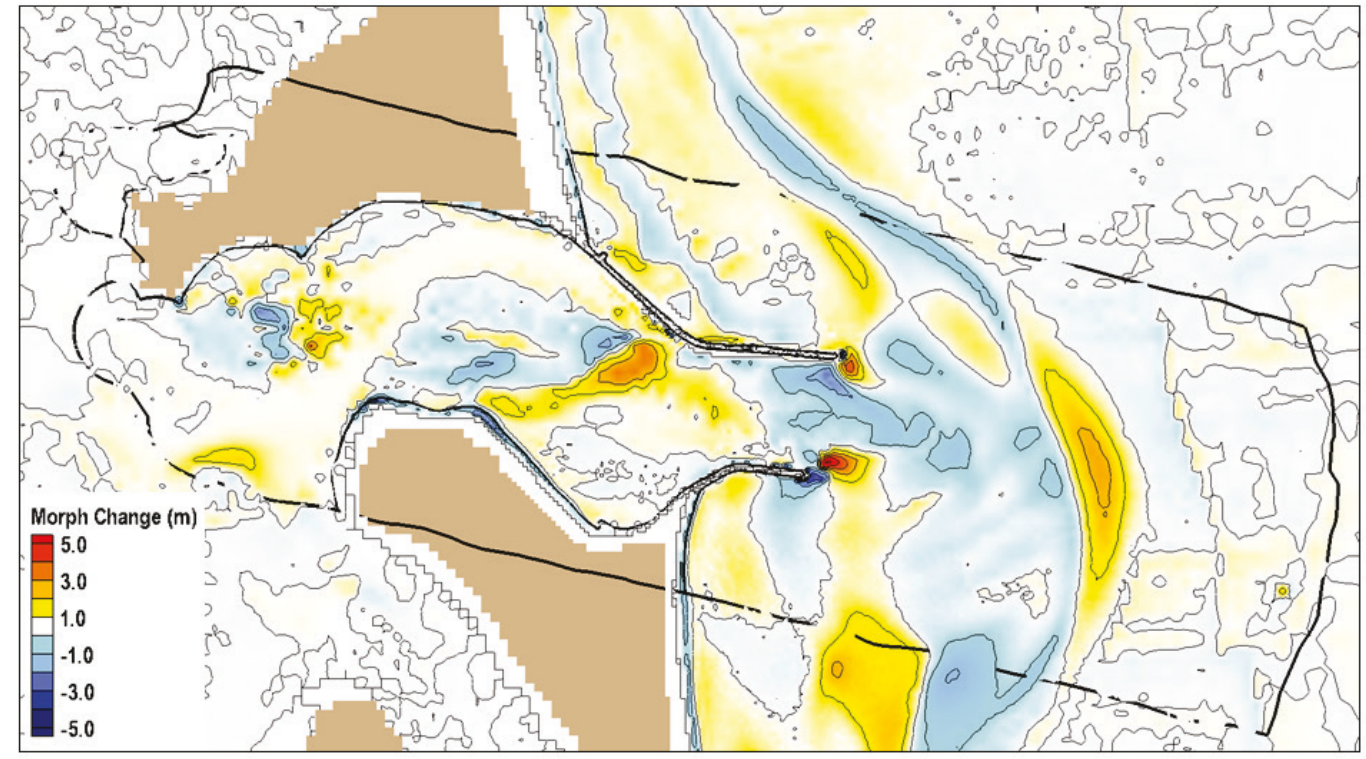


Table 3-5. Observed and calculated bed volume changes in Merrimack Inlet from December 2014 to June 2015.

\begin{tabular}{|crrr|}
\hline Sub-region & \multicolumn{1}{c}{$\begin{array}{c}\text { LIDAR } \\
\left(\mathrm{m}^{3}\right)\end{array}$} & \multicolumn{1}{c|}{$\begin{array}{c}\text { CMS } \\
\left(\mathrm{m}^{3}\right)\end{array}$} & $\begin{array}{c}\text { Trend in Volume } \\
\text { Change }\end{array}$ \\
\hline 1 & -14363 & 9602 & Inconsistent \\
2 & 27678 & -6683 & Inconsistent \\
3 & 7812 & 20015 & Consistent \\
4 & -27714 & -32202 & Consistent \\
5 & -57381 & -15198 & Consistent \\
6 & 2036 & 3791 & Consistent \\
7 & -1049 & -3092 & Consistent \\
8 & 6624 & 5086 & Consistent \\
9 & -1470 & -47215 & Consistent \\
10 & -215929 & -63843 & Consistent \\
11 & 1272 & 21722 & Consistent \\
12 & 12823 & -2921 & Inconsistent \\
13 & 3556 & -9799 & Inconsistent \\
14 & -7395 & -4117 & Consistent \\
Total & -263499 & -124854 & Consistent \\
\hline
\end{tabular}

\subsubsection{CMS simulations (December 2014-June 2015)}

Similar to the analysis in Section 3.1, the CMS output of the 6-month simulations was averaged, and mean current, wave, and sediment transport fields were obtained and shown in Figure 92, Figure 93, and Figure 94, respectively. 
Figure 92. Simulated mean current field (15 December 2014 and 15 June 2015).

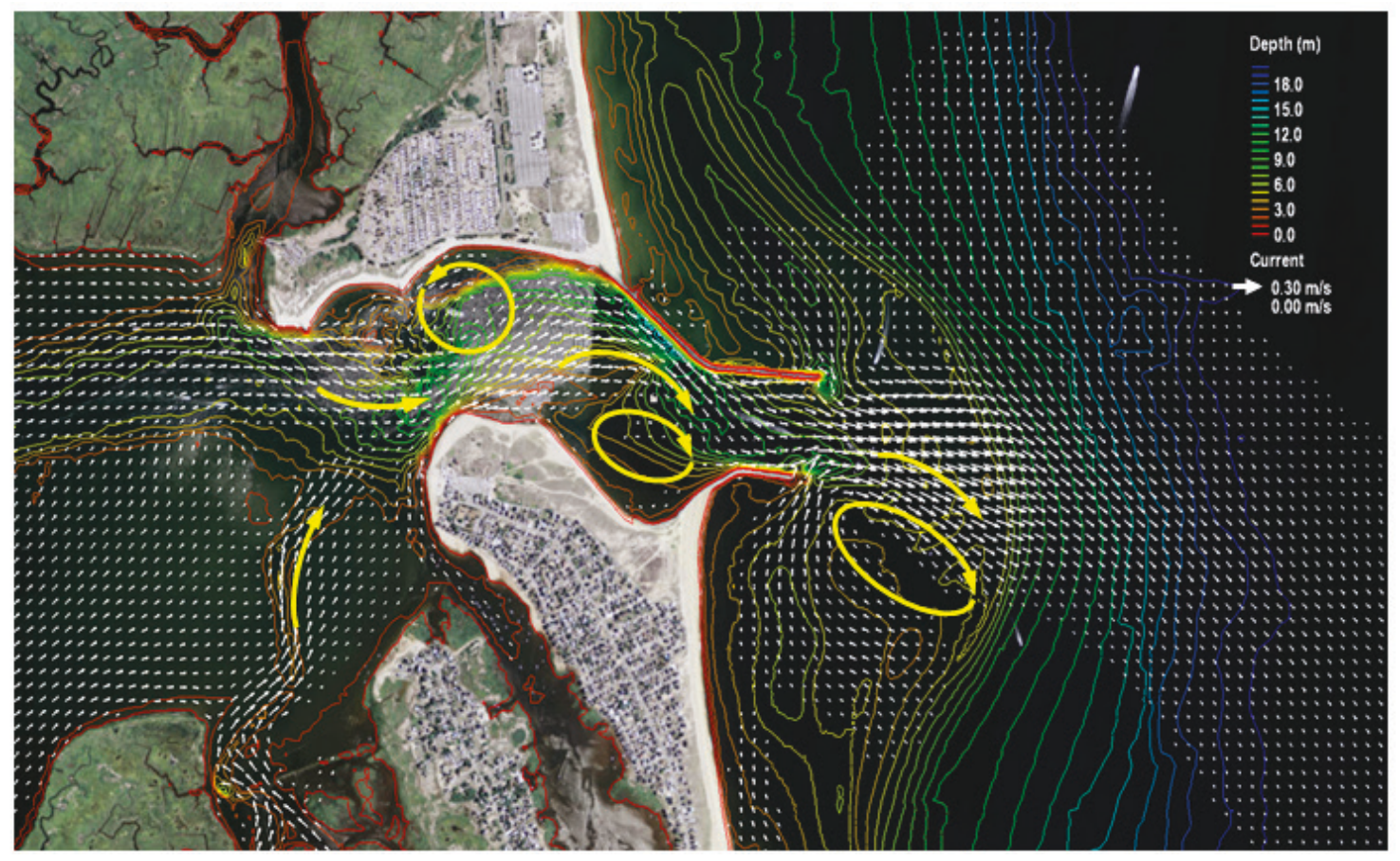

Figure 93. Simulated mean wave field (15 December 2014 and 15 June 2015).

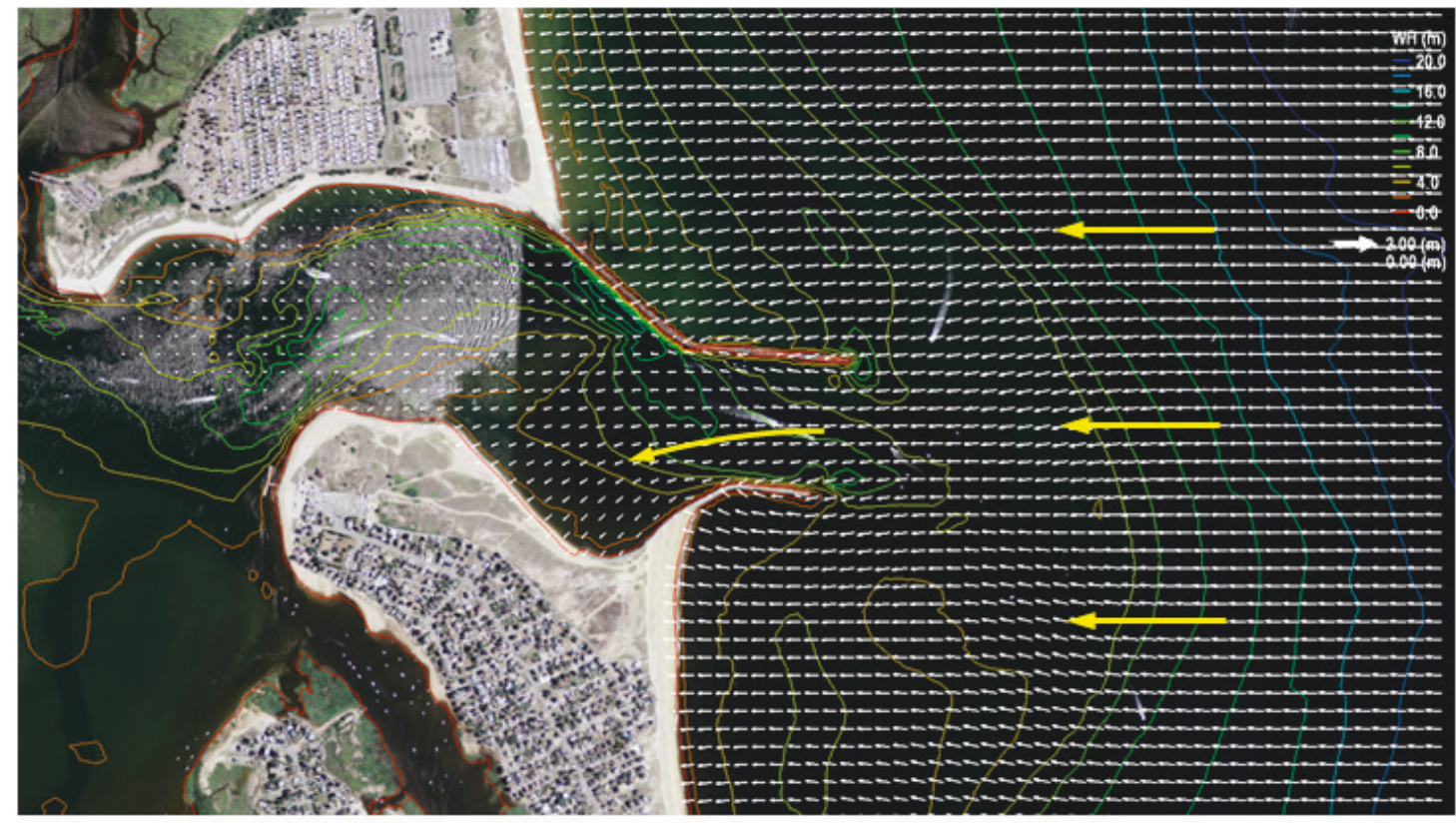


Figure 94. Simulated mean sediment transport field (15 December 2014 and 15 June 2015).

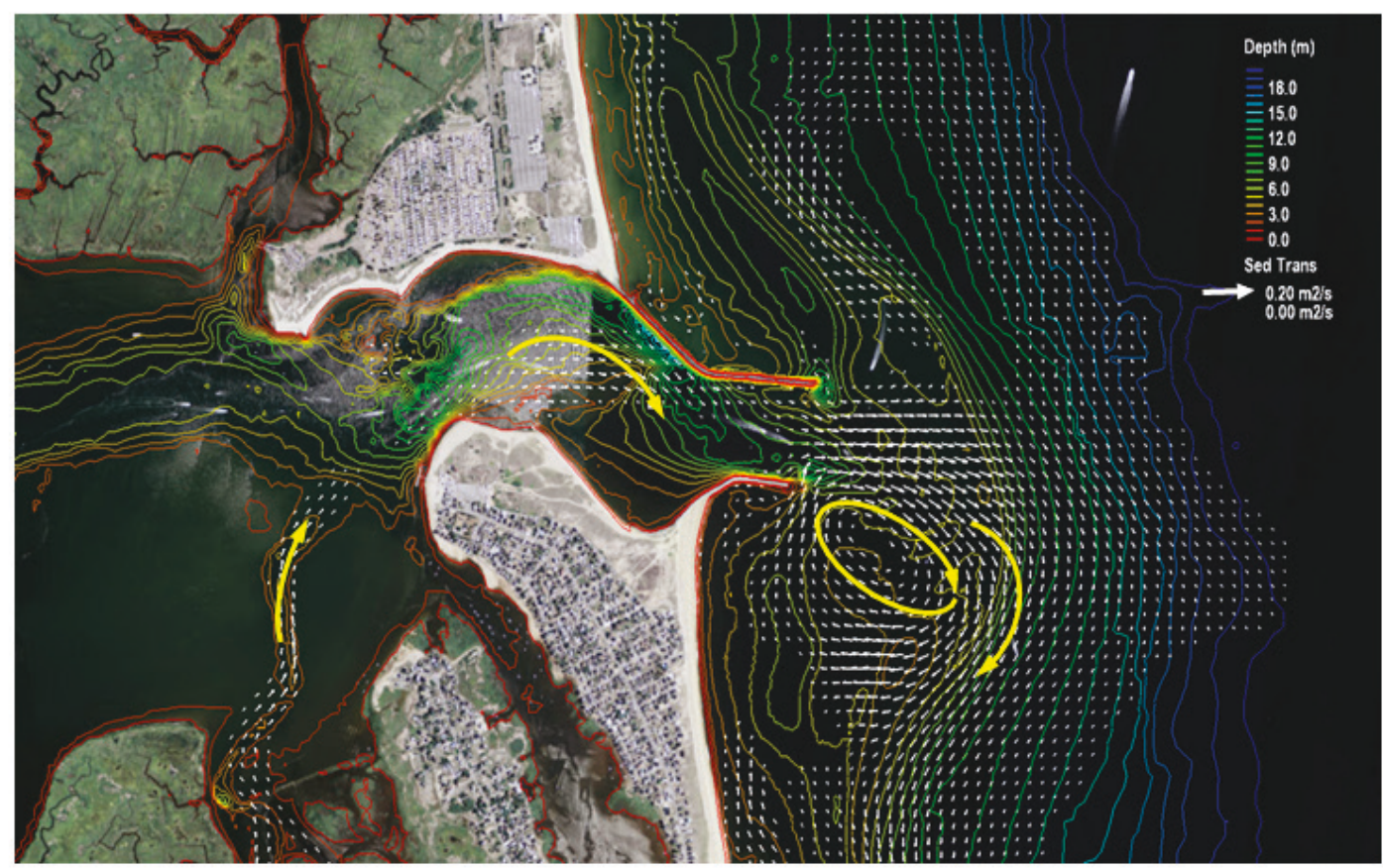

Mean currents in Figure 92 show a consistent flow pattern as in Figure 62: outflow through the inlet is directed towards the southeast, and the alongshore current runs from north to south. Three small-scale eddies can be identified south of ebb tidal delta, north of Plum Island within the inlet, and north of the navigation channel near Badgers Rock. Inside the Sound west of Plum Island, the mean current flows from south to north and merges with the outflow in navigation channel. The maximum current appears over the ebb tidal shoal with a velocity of $0.3 \mathrm{~m} / \mathrm{s}(0.98 \mathrm{ft} / \mathrm{s})$.

As shown in Figure 93, mean incident waves propagate from the east, and

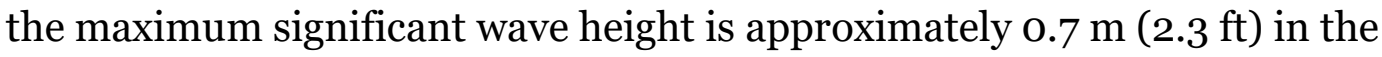
open ocean. Entering the inlet, wave energy is dissipated as waves are diffracted and reflected between the jetties and refracted as they approach interior shorelines. The mean significant wave height is reduced to 0.2 to $0.3 \mathrm{~m}$ ( 0.66 to $0.98 \mathrm{ft} / \mathrm{s})$ north of Plum Island.

Current and waves are driving sediment movement. The pattern of mean sediment transport shown in Figure 94 corresponds well to the mean current distribution. The maximum transport vector occurs over the ebb tidal delta. Two areas with weak transport can be seen on the north and south sides of the ebb tidal delta. In the open ocean, sediment moves to the south, carried by the net alongshore current. Corresponding to the 
dominance of the wave forcing, sediment erosion occurs over the ebb tidal delta, and accretion appears on the north and south sides of the shoal (Figure 91).

\subsubsection{Fully rehabilitated south Jetty condition}

\section{Base Condition}

The validated CMS described in Section 3.2.1 provides the base model for the Phase II study. The initial bathymetry was updated by incorporating the 2014 lidar survey in the Phase I bathymetry with the fully rehabilitated South Jetty. The base and alternative simulations were conducted for 6 months from 15 December 2014 to 15 June 2015.

Figure 95 shows the morphology change and final bathymetry under the base condition at the end of the 6-month simulation. To examine the erosion/accretion trend and bed volume change around the inlet system, Salisbury Beach, north Plum Island within the South Jetty, and Plum Island Beach facing open ocean were divided into five polygon areas: Salisbury, Inside, North, Middle, and South. Bed volume changes within those areas were calculated and compared between the base and each alternative case. Figure 96 shows the bed volume change under the base condition in each polygon area and the total volume change in the east side of Plum Island (North, Middle, and South areas) after the 6-month simulation. The negative value indicates the loss of sediment within a beach area, and the positive indicates the gain of sediment within a beach area. Through the simulation net, erosion occurs in the Salisbury and inside areas. South of the South Jetty, the North area shows sediment accretion, but the total bed volume change still corresponds to net loss of sediment east of Plum Island. 
Figure 95. Base Condition after 6-month simulation; morphology change (left) and final bathymetry (right)

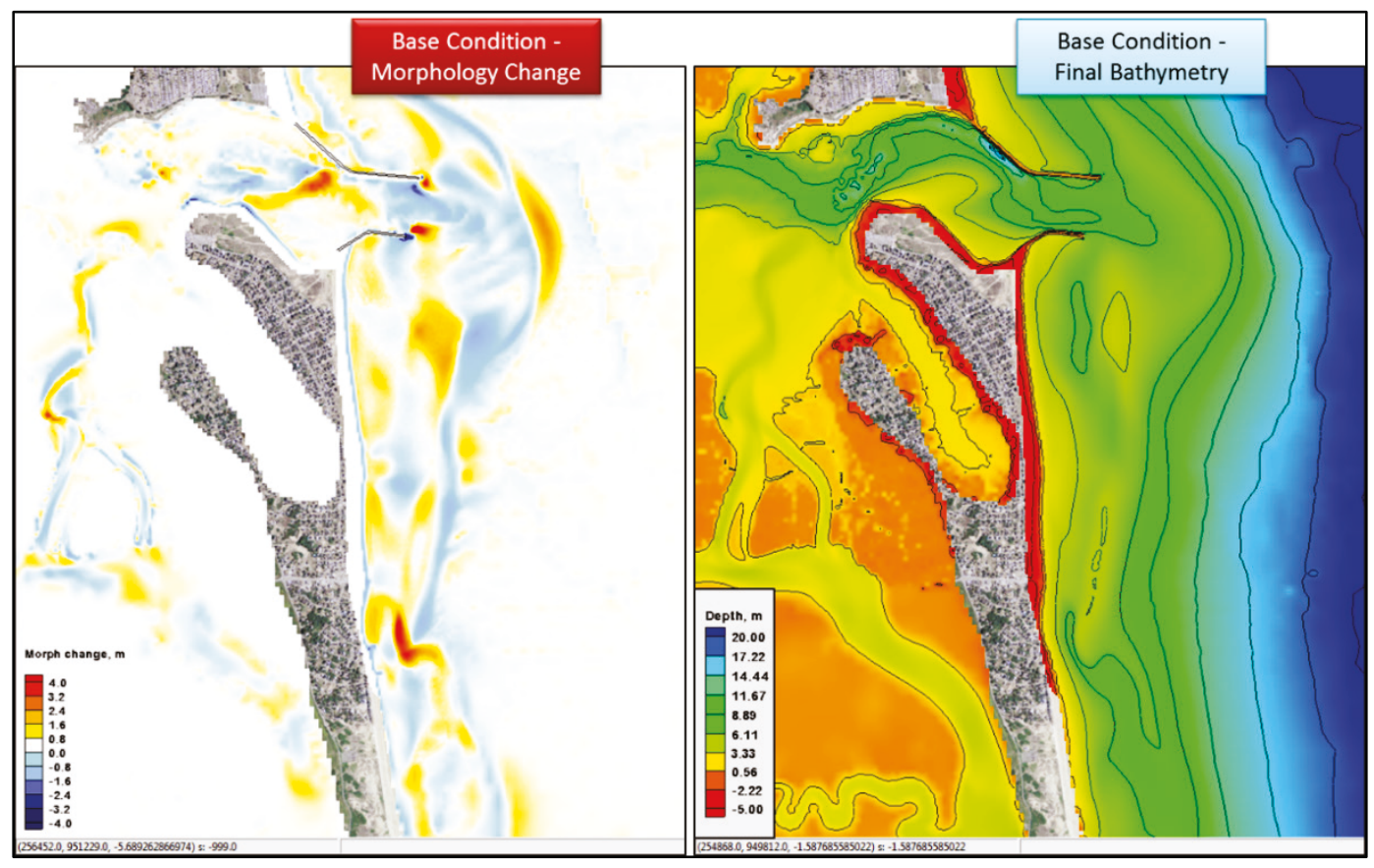

Figure 96 . Five polygon areas and bed volume changes within each area after 6-month simulation.

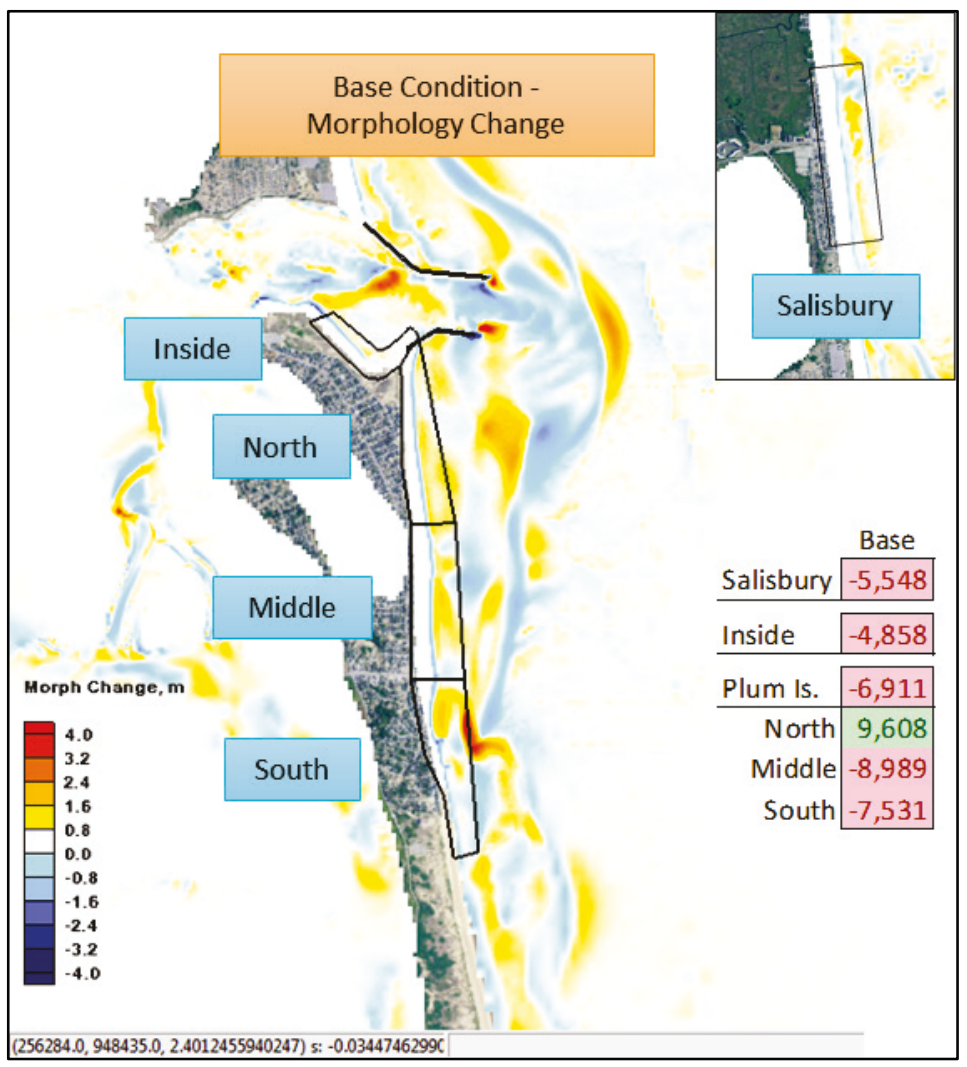




\section{Ebb Delta Mining, Alternative 1 (6 months)}

Figure 97 shows initial and final bathymetry of Alternative 1 and difference in morphology change between Alternative 1 and base condition after the 6-month simulation. It can be seen that this alternative changed sand transport pattern around the inlet and the mining/placement zones. Primary features are sand infilling in the mined area south of the ebb tidal delta and bed erosion in the placement zones in front of Salisbury Beach and Plum Island Beach. More sand migrated shoreward from the placement zones.

Figure 97. Initial bathymetry and final bathymetry of Alternative 1 and difference in morphology change between Alternative 1 and base condition.

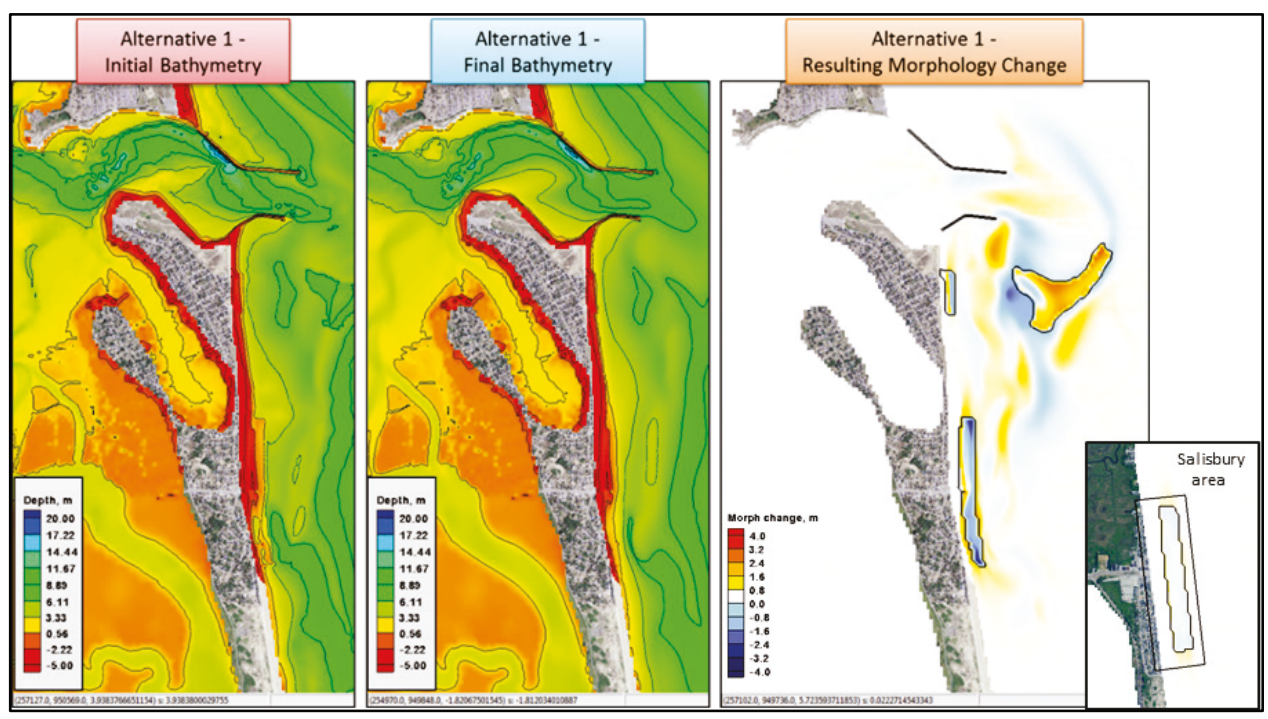

Figure 98 shows the net bed volume changes of and the difference between the base condition and Alternative 1 in the five polygon areas after the 6-month simulation. Related to mining and placement, the pattern changes in flow and sediment transport under Alternative 1 result in infilling in the mined area and erosion from the placement area. Comparing with the base condition, approximately $135,622 \mathrm{more}^{3}$ (177,400 cu yd) of sediment (35.5\% of mined $383,250 \mathrm{~m}^{3}$ [500,000 cu yd] of sediment) filled in the mined area. An amount of $3,517 \mathrm{~m}^{3}$ (4,600 cu yd) of placed material (4.6\% of original placed $76,450 \mathrm{~m}^{3}[100,000 \mathrm{cu} \mathrm{yd}]$ of sand) eroded and moved shoreward from the Salisbury placement zone. An amount of 5,046 less $\mathrm{m}^{3}$ $(6,600 \mathrm{cu} y d)$ of material deposited in the North area, and amounts of $9,327,12,079$, and 16,437 more $\mathrm{m}^{3}$ (12,200, 15,800, and 21,500 cu yd) deposited in the Middle, South areas, and east of Plum Island. Within the South Jetty, the inside area under Alternative 1 shows more but small erosion. 
Figure 98. Difference in morphology change and bed volume changes within each beach area between Alternative 1 and base condition after 6-month simulation.

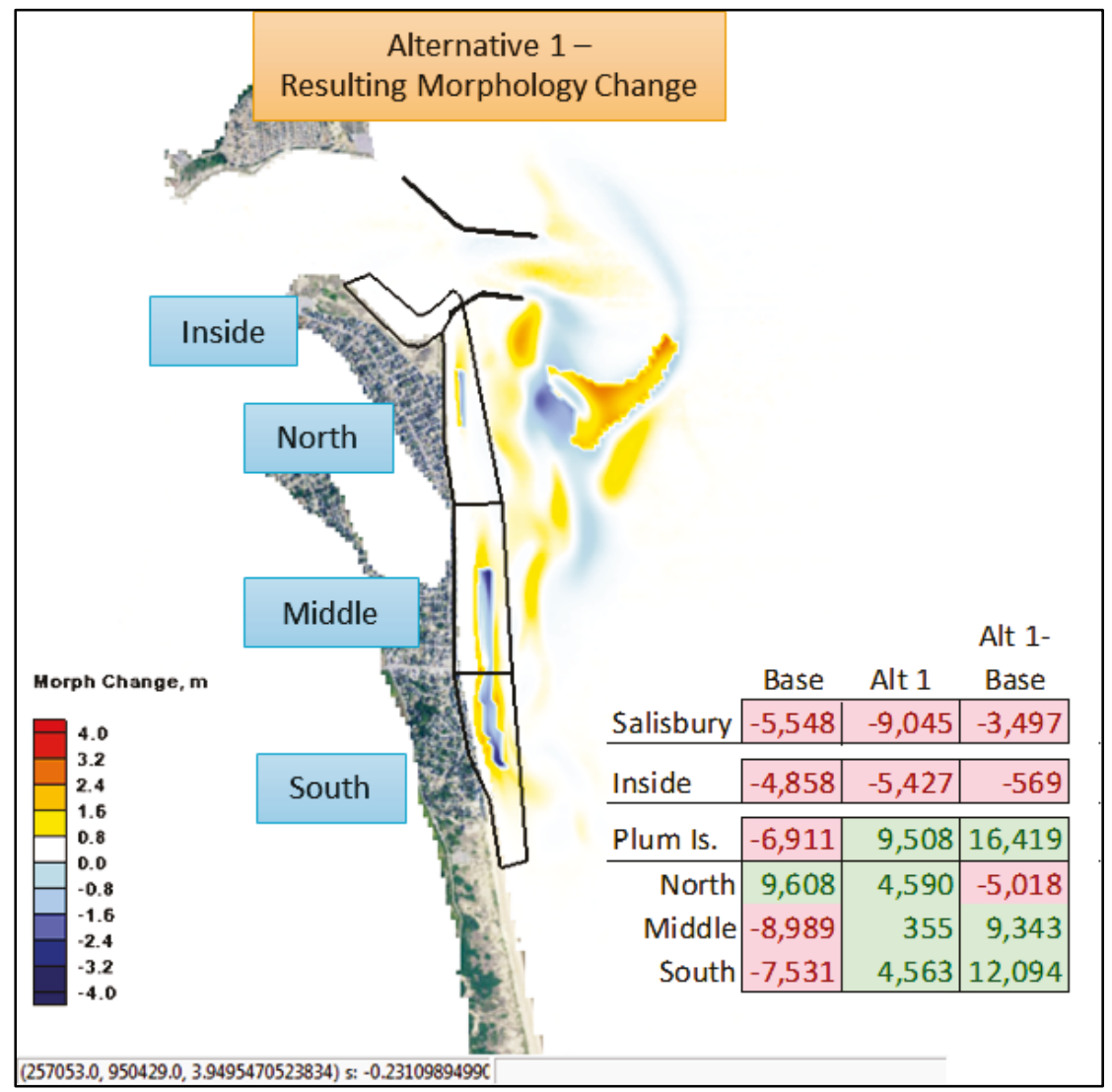

Flood Delta Mining, Alternative 2 (6 months)

Mining flood tidal delta, no noticeable morphology change was observed around the inlet (Figure 99). Similar to Alternative 1, morphology changes in three placement zones show shoreward material migration. Figure 100 shows that the changes in flow and sediment transport under Alternative 2 result in infilling in the mined area and erosion from the placement area. Comparing with the base condition, approximately 13,226 more $\mathrm{m}^{3}$ $\left(17,300 \mathrm{cu}\right.$ yd) of sediment $\left(3.5 \%\right.$ of mined $383,250 \mathrm{~m}^{3}$ [500,000 cu yd] of sediment) filled in the mined area. An amount of $3,593 \mathrm{~m}^{3}$ (4,700 cu yd) of placed material (4.7\% of original placed $76,450 \mathrm{~m}^{3}[100,000 \mathrm{cu}$ yd] of sand) eroded and moved shoreward from the Salisbury placement zone. An amount of 1,453 less m3 (1,900 cu yd) of material deposited in North areas, and amounts of 10,397, 12,003, and 21,024 more $\mathrm{m}^{3}(13,600$, 15,700 , and 27,500 cu yd) deposited in the Middle, South areas, and east of Plum Island. Different from the erosion trend under Alternative 1, the Inside area under Alternative 2 has shown an accretion trend due to its closeness to the mining zone. 
Figure 99. Initial bathymetry and final bathymetry of Alternative 2 and difference in morphology change between Alternative 2 and base condition.

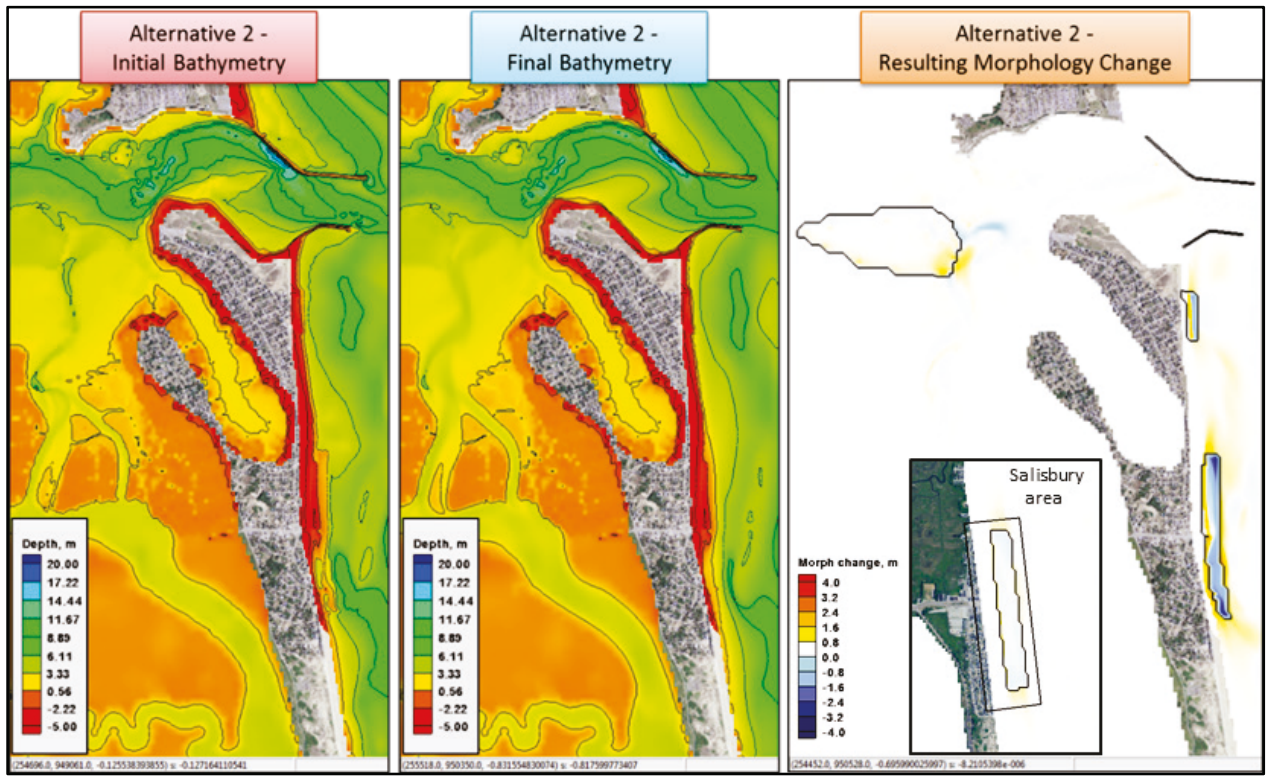

Figure 100. Difference in morphology change and bed volume changes within each beach area between Alternative 2 and base condition after 6-month simulation.

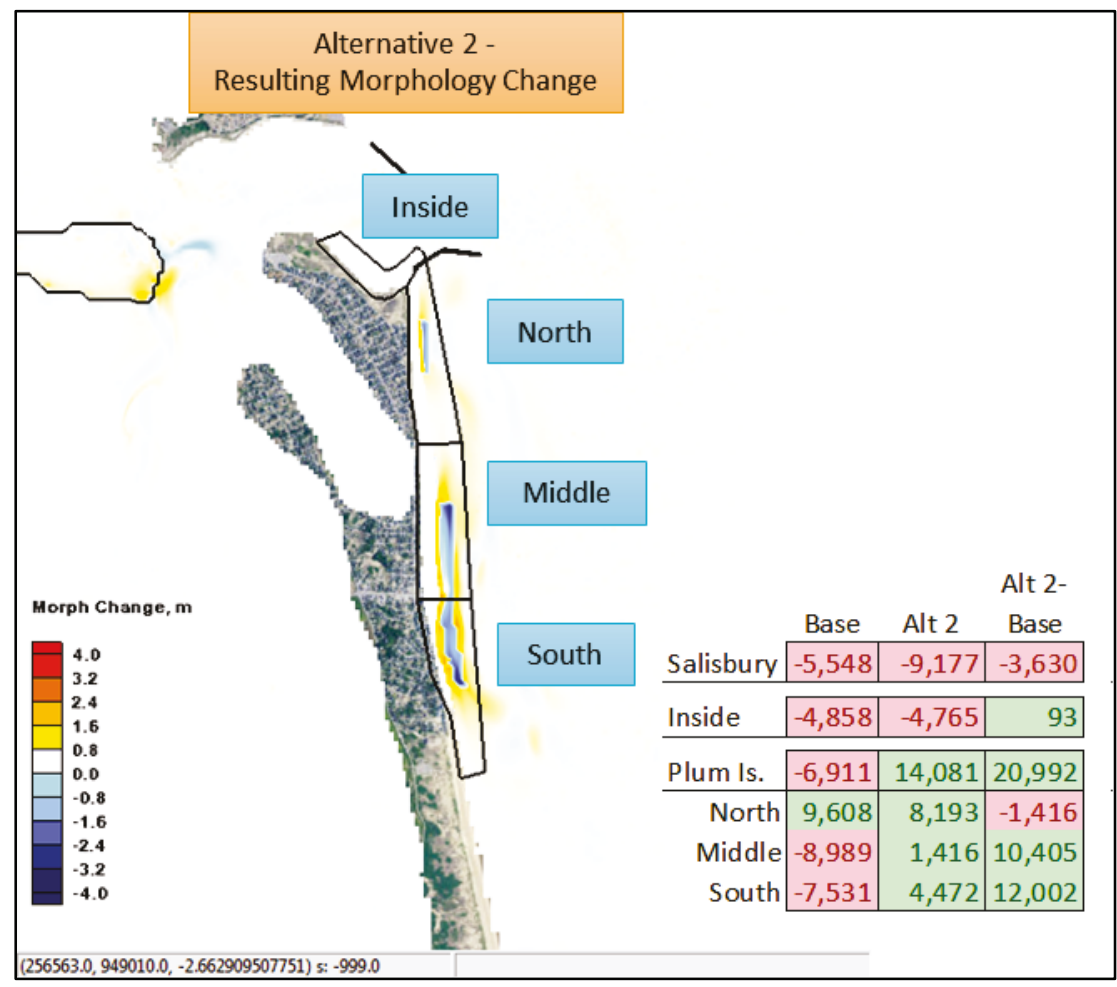




\section{Modified North Point, Plum Island Mining, Alternative $3 \mathrm{c}$ (6 months)}

Comparing with the base condition, the morphology change for Alternative $3 \mathrm{c}$ condition is directly related to the change in the mining zone with a noticeable sand movement north of Plum Island (Figure 101). Comparing with the base condition, 72,322 more $\mathrm{m}^{3}$ (94,600 $\mathrm{cu} \mathrm{yd}$ ) of sediment (25.2\% of mined $286,688 \mathrm{~m}^{3}$ [375,000 cu yd] of sediment) filled in the mined area. Figure 102 shows that 3,823 more $\mathrm{m}^{3}$ (5,000 cu yd) of placed material (5.0\% of original placed $76,450 \mathrm{~m}^{3}[100,000 \mathrm{cu} \mathrm{yd}]$ of sand) eroded from the Salisbury placement zone. The amounts of 1,758 and 2,217 more $\mathrm{m}^{3}$ (2,300 and 2,900 cu yd) of material eroded in Inside and North areas, and amounts of 9,250, 14,984, and 22,094 more m3 $(12,100,19,600$, and 28,900 cu yd) deposited in the middle, south areas, and east of Plum Island. The Salisbury, North, Middle, and South areas have a similar pattern of local deposition/erosion as Alternatives 1 and 2.

Figure 101. Initial bathymetry and final bathymetry of Alternative $3 \mathrm{c}$ and difference in morphology change between Alternative $3 \mathrm{c}$ and base condition.

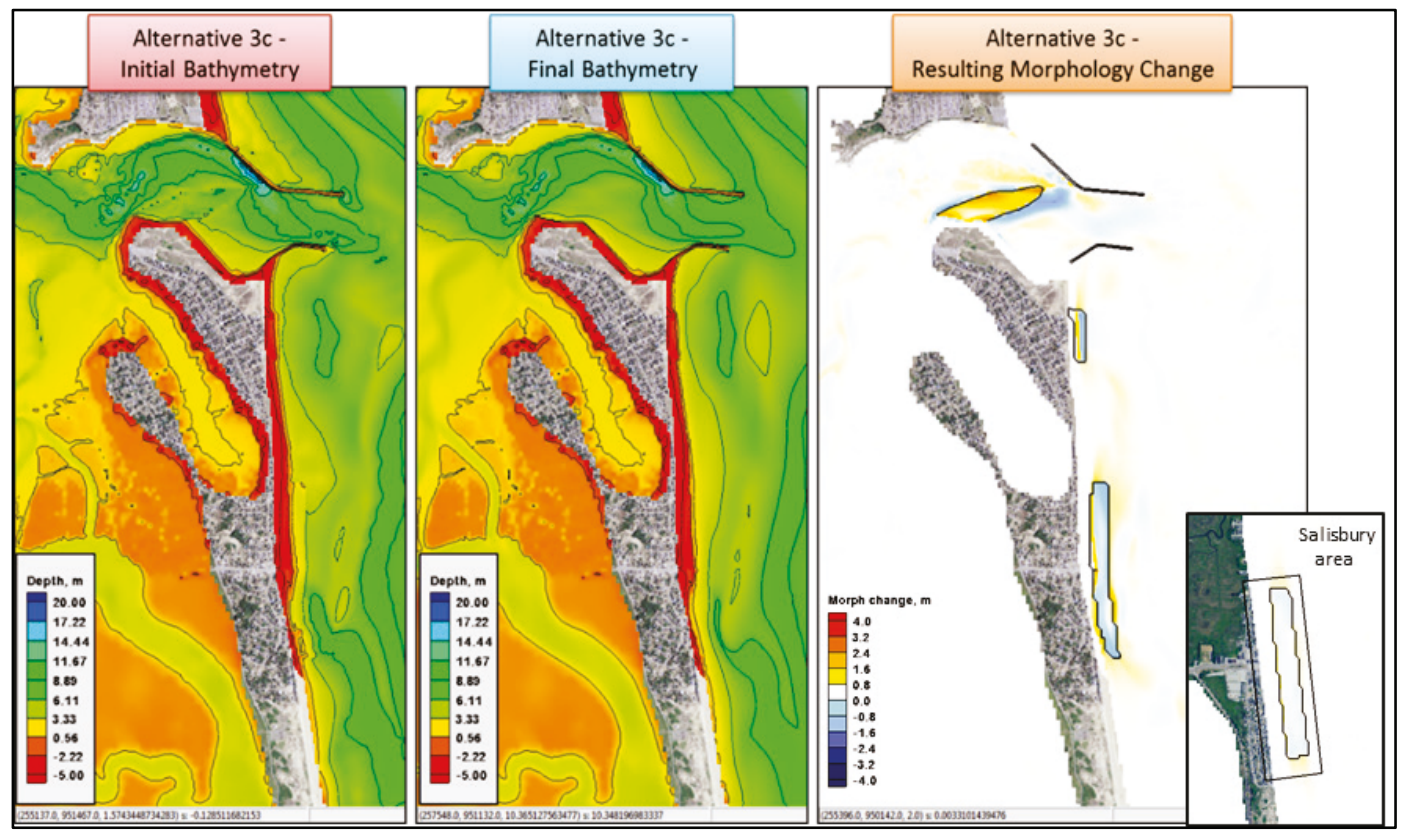


Figure 102. Difference in morphology change and bed volume changes within each beach area between Alternative $3 c$ and base condition after 6 -month simulation.

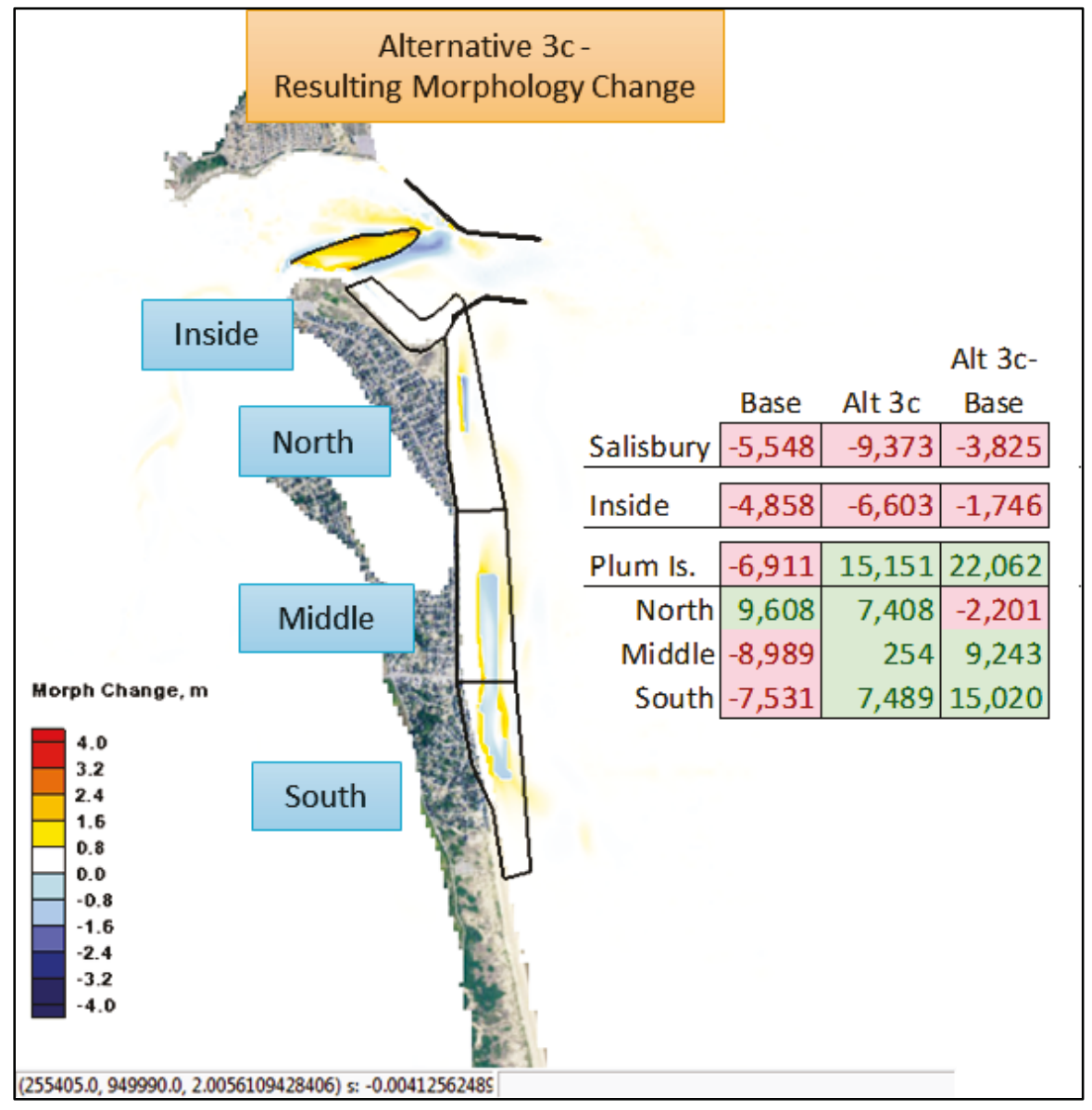

Shorten Jetties, Alternative 9 (6 months)

Removing the outer portion of each jetty changes the flow and sediment transport pattern around the inlet entrance, navigation channel, and ebb tidal delta (Figure 103). With the shortened jetties, sediment moves towards the channel, and significant channel infilling occurs. Relative to the base condition, 26,834 more $\mathrm{m}^{3}$ (35,100 cu yd) of sediment accreted in the channel area and 72,322 more $\mathrm{m}^{3}$ (94,600 cu yd) of sediment eroded in the ebb shoal area. Figure 104 shows that 7,569 more $\mathrm{m}^{3}$ (9,900 cu yd) of material eroded in the Inside area due to its closeness to the inlet entrance, and significant accretion occurred in the North, Middle, and South areas comparing with the base condition. East of Plum Island, 47,399 more $\mathrm{m}^{3}$ (62,000 cu yd) of sediment deposited. This alternative does affect the downdrift area of the inlet but does not much affect the updrift (Salisbury) area in morphology change. 
Figure 103. Initial bathymetry and final bathymetry of Alternative 9 and difference in morphology change between Alternative 9 and base condition.

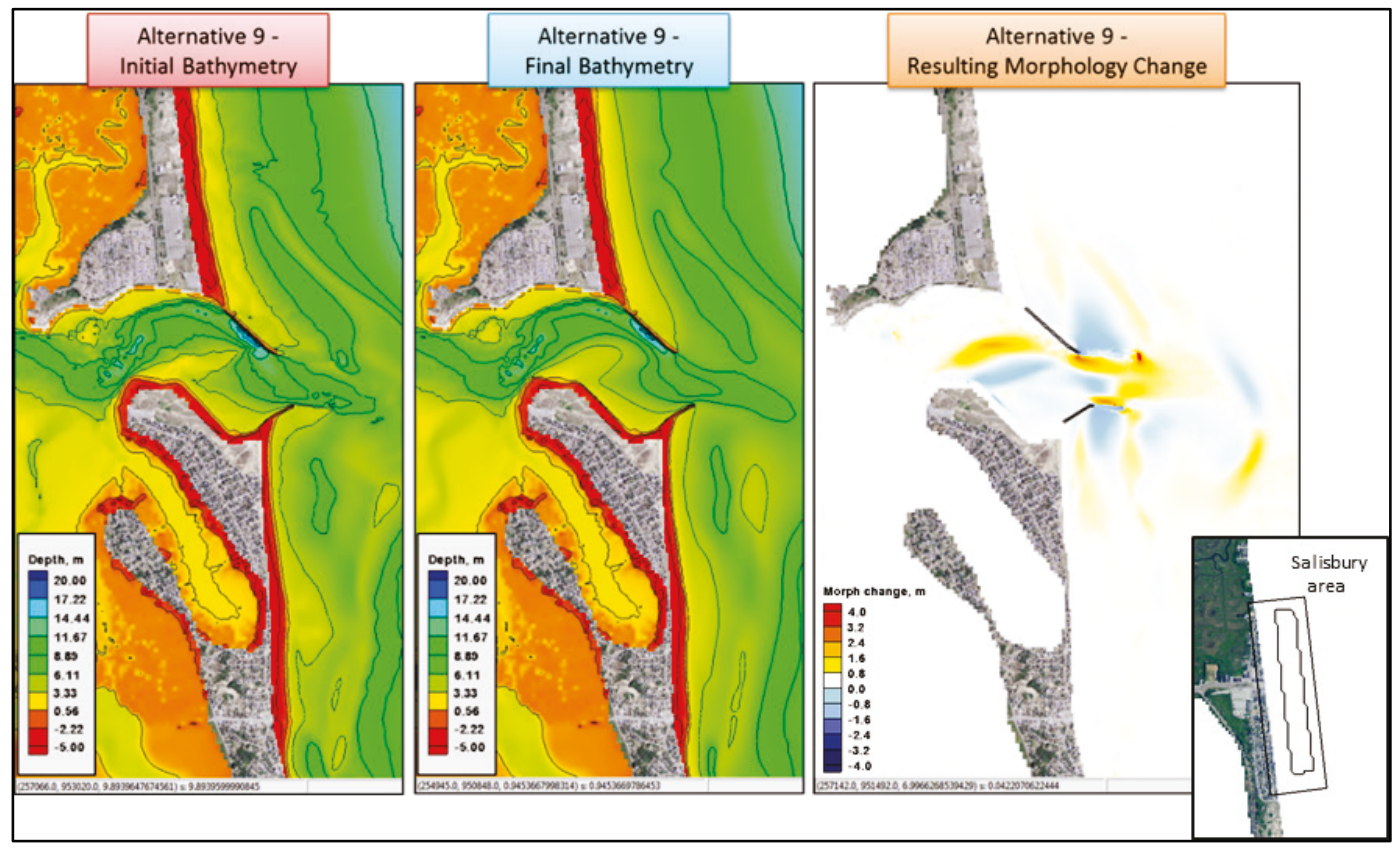

Figure 104. Difference in morphology change and bed volume changes within each beach area between Alternative 9 and base condition after 6-month simulation.

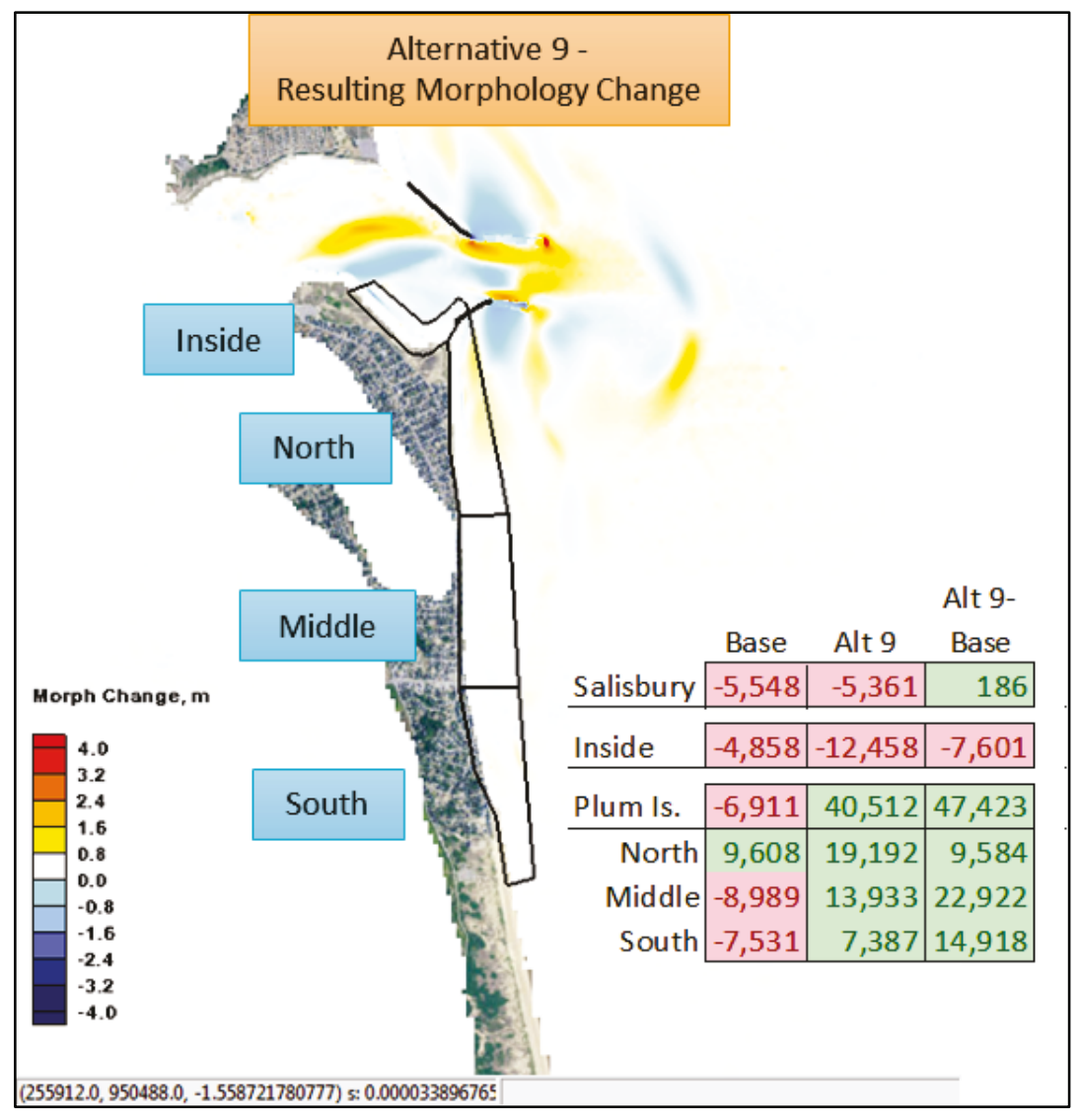




\section{Expanded Detached Breakwaters, Alternative 15b (6 months)}

Comparing with the base condition, the nearshore area between the top (northern) four detached breakwaters and the beach front shows that 3,211 less $\mathrm{m}^{3}$ (4,200 cu yd) of sand accreted and the area between the bottom (southern) four detached breakwaters, and the beach front 12,308 more $\mathrm{m}^{3}$ (16,100 cu yd) of sand eroded during the 6-month simulation. Under the protection of the detached breakwaters, more sediment material accumulation can be observed on the lee side of the detached breakwaters (Figure 105 and Figure 106). As expected, expanding detached breakwaters in front of Plum Island Beach has insignificant impact on bed volume changes in the Salisbury and the Inside areas. However, the sediment erosion due to the detached breakwaters results in net material loss in the North and Middle areas, and material gain in the South area.

Figure 105. Initial bathymetry and final bathymetry of Alternative $15 \mathrm{~b}$ and difference in morphology change between Alternative $15 \mathrm{~b}$ and base condition.

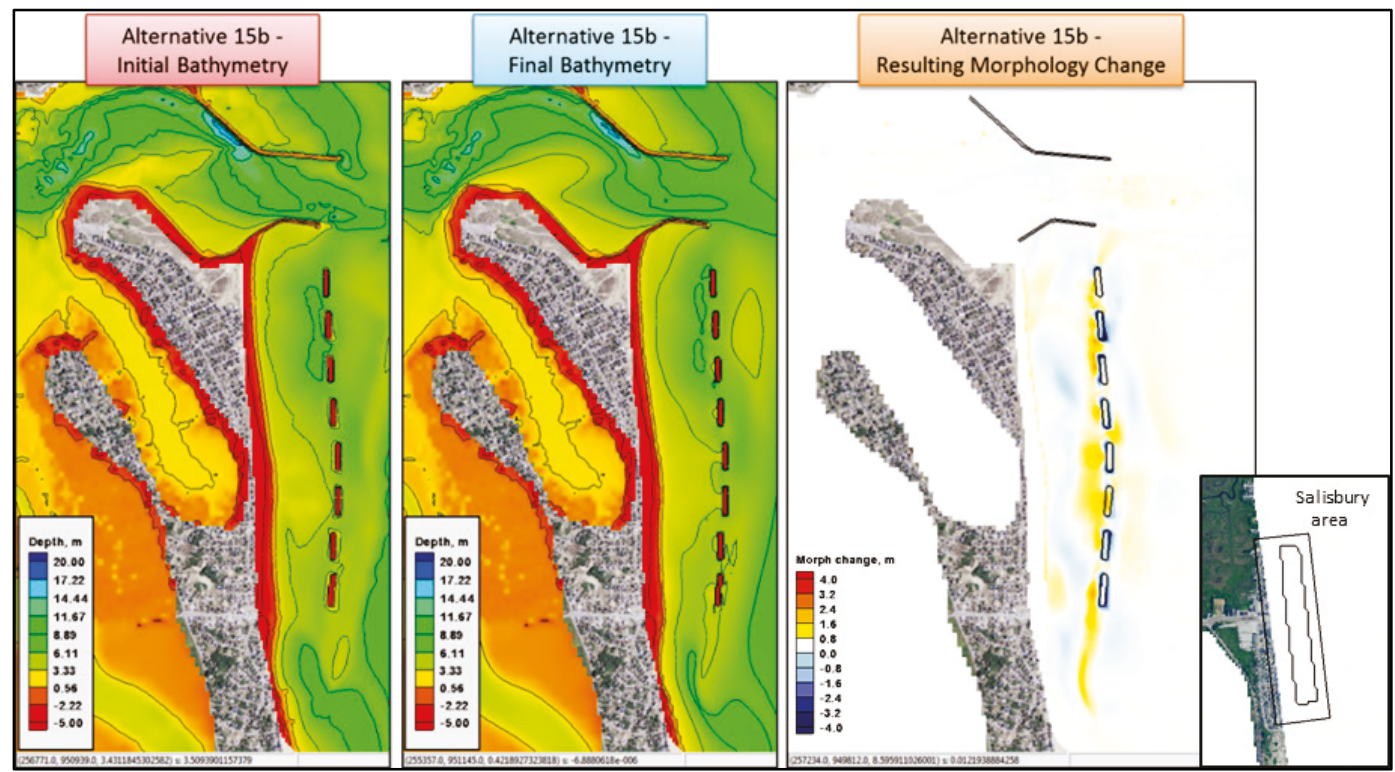


Figure 106. Difference in morphology change and bed volume changes within each beach area between Alternative $15 \mathrm{~b}$ and base condition after 6-month simulation.

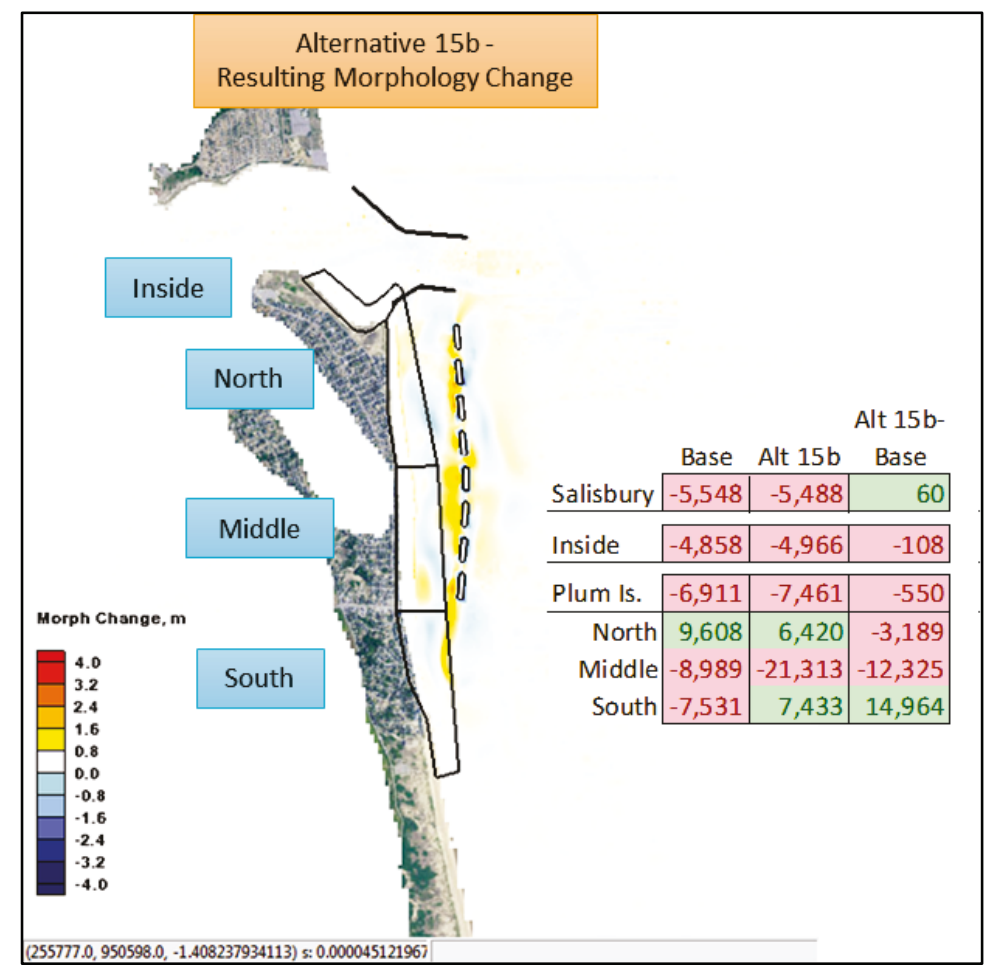

Expanded Detached Breakwaters and Ebb Shoal Mining, Alternative 15d (6 months)

By combining Alternative 15b with Alternative 1, the features in sediment transport and morphology change are shown in Figure 107, which include accretion in the mined zone, in front of Plum Island Beach, and on the lee side of the breakwaters and erosion in the placement zones. Comparing with the base condition, approximately 136,157 more $\mathrm{m}^{3}(178,100 \mathrm{cu} \mathrm{yd})$ of sediment (35.6\% of mined $382,250 \mathrm{~m}^{3}$ [500,000 cu yd] of sediment) filled in the mined area. An amount of 3,593 more $\mathrm{m}^{3}$ (4,700 cu yd) of placed material (4.7\% of original placed $76,450 \mathrm{~m}^{3}[100,000 \mathrm{cu} \mathrm{yd}]$ of sand) eroded and moved shoreward from the Salisbury placement zone, and only 612 more $^{3}$ ( 800 cu yd) of sediment eroded in the inside area. The nearshore area between the top (northern) four detached breakwaters and the beach front shows that 5,657 less $\mathrm{m}^{3}$ (7,400 cu yd) of sand accreted. The amounts of $11,773,9,939$, and 16,131 more $\mathrm{m}^{3}(15,400,13,000$, and $21,100 \mathrm{cu}$ yd) deposited in the Middle, South areas, and east of Plum Island. The results in Figure 108 indicate that the bed volume changes in all five polygon areas are very similar to those obtained under Alternative 1 condition and are dominated by this sediment management alternative. 
Significantly more sediment is accumulated in the Middle and the South areas due to the detached breakwaters and nearshore placement.

Figure 107. Initial bathymetry and final bathymetry of Alternative $15 \mathrm{~d}$, and difference in morphology change between Alternative $15 \mathrm{~d}$ and base condition.

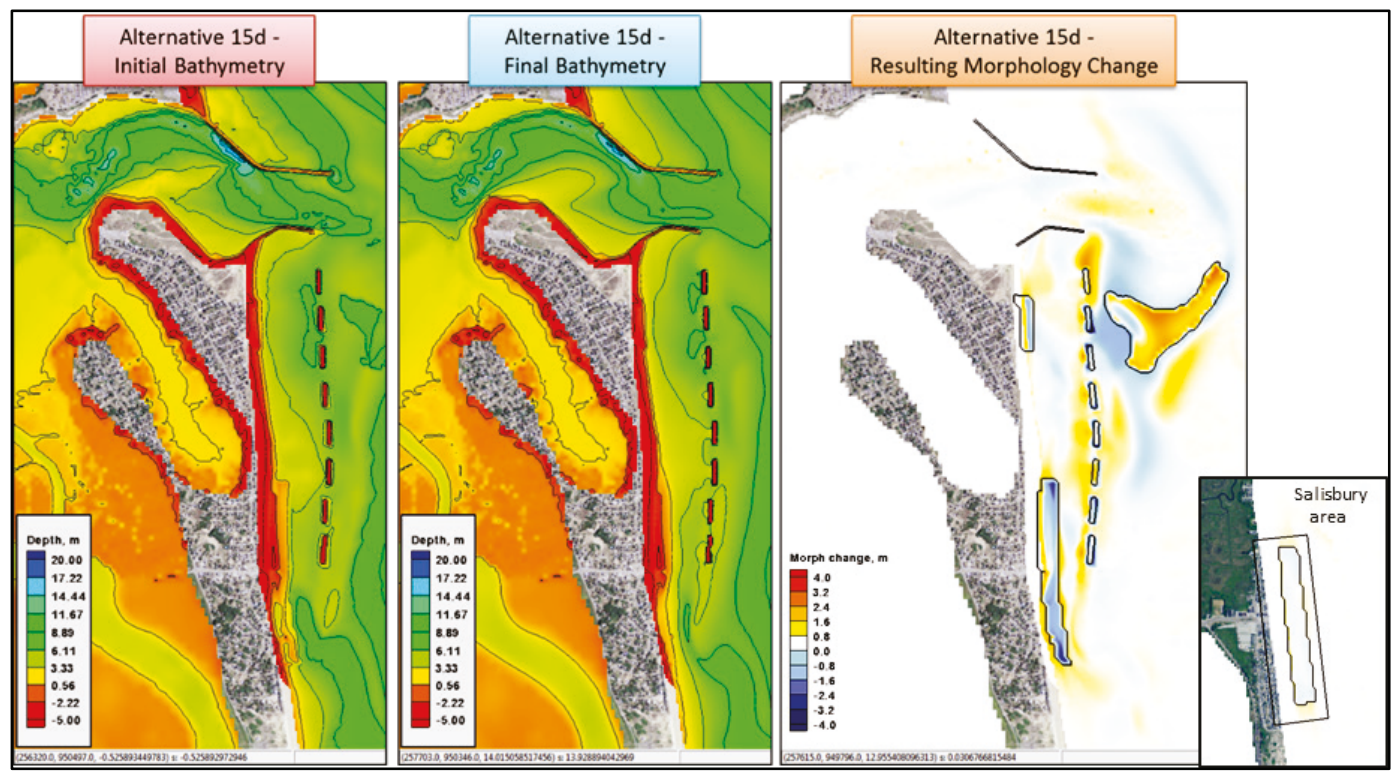

Figure 108. Difference in morphology change and bed volume changes within each beach area between Alternative $15 \mathrm{~d}$ and base condition after 6-month simulation.

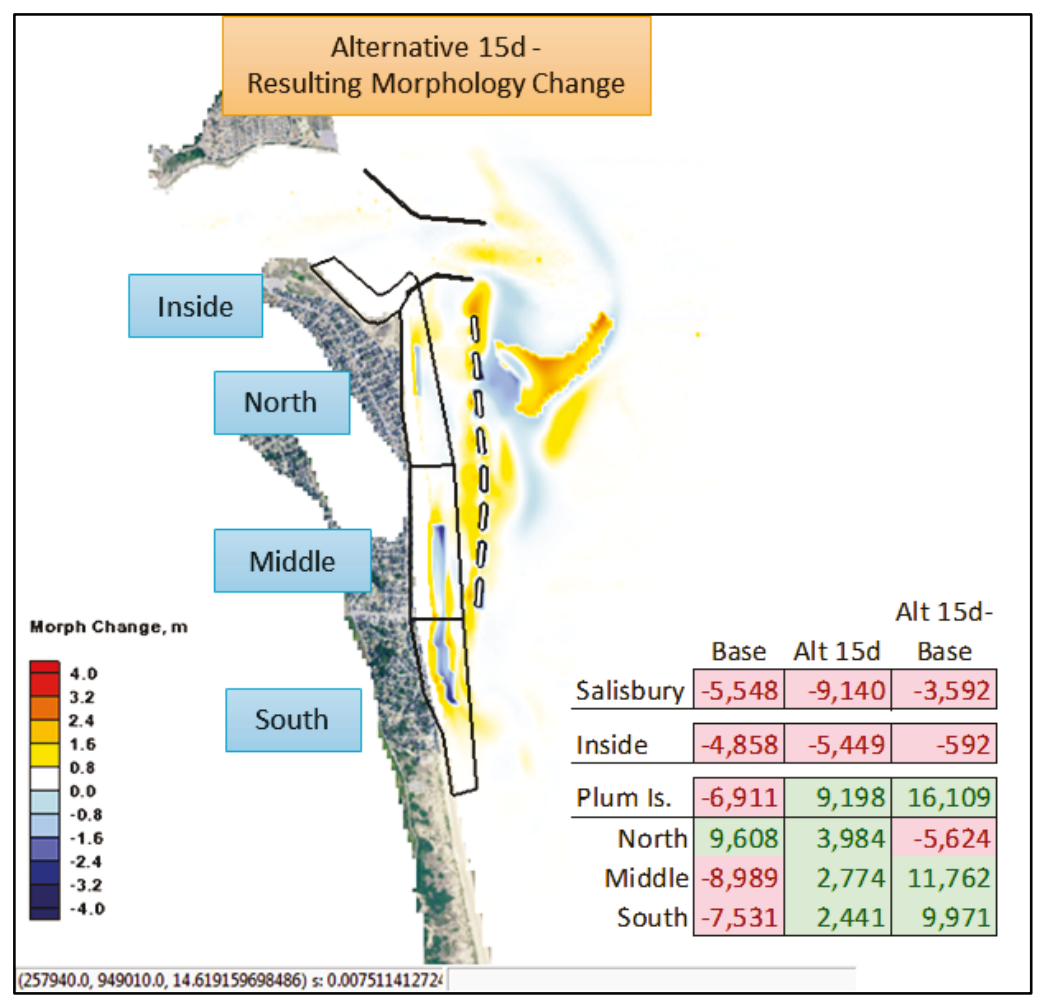


$\underline{\text { Shifted Expanded Detached Breakwaters, Alternative 15e (6 months) }}$

Moving four breakwaters southward to a deeper area changes the flow and sediment transport pattern as shown in Figure 109. Removing the four breakwaters in the North area, 4,052 $\mathrm{m}^{3}$ (5,300 cu yd) of sediment erosion is observed rather than accretion calculated in Alternative 15b, which could be related to the significant increase of bed volume in the Middle area (12,538 $\mathrm{m}^{3}[16,400 \mathrm{cu} \mathrm{yd}]$ of sediment accretion). Comparing with the base condition, the Salisbury and Inside areas do not show much bed volume changes, and the South area shows less sediment erosion due to the building of detached breakwaters (Figure 110).

Figure 109. Initial bathymetry and final bathymetry of Alternative $15 \mathrm{e}$ and difference in morphology change between Alternative $15 \mathrm{e}$ and base condition.

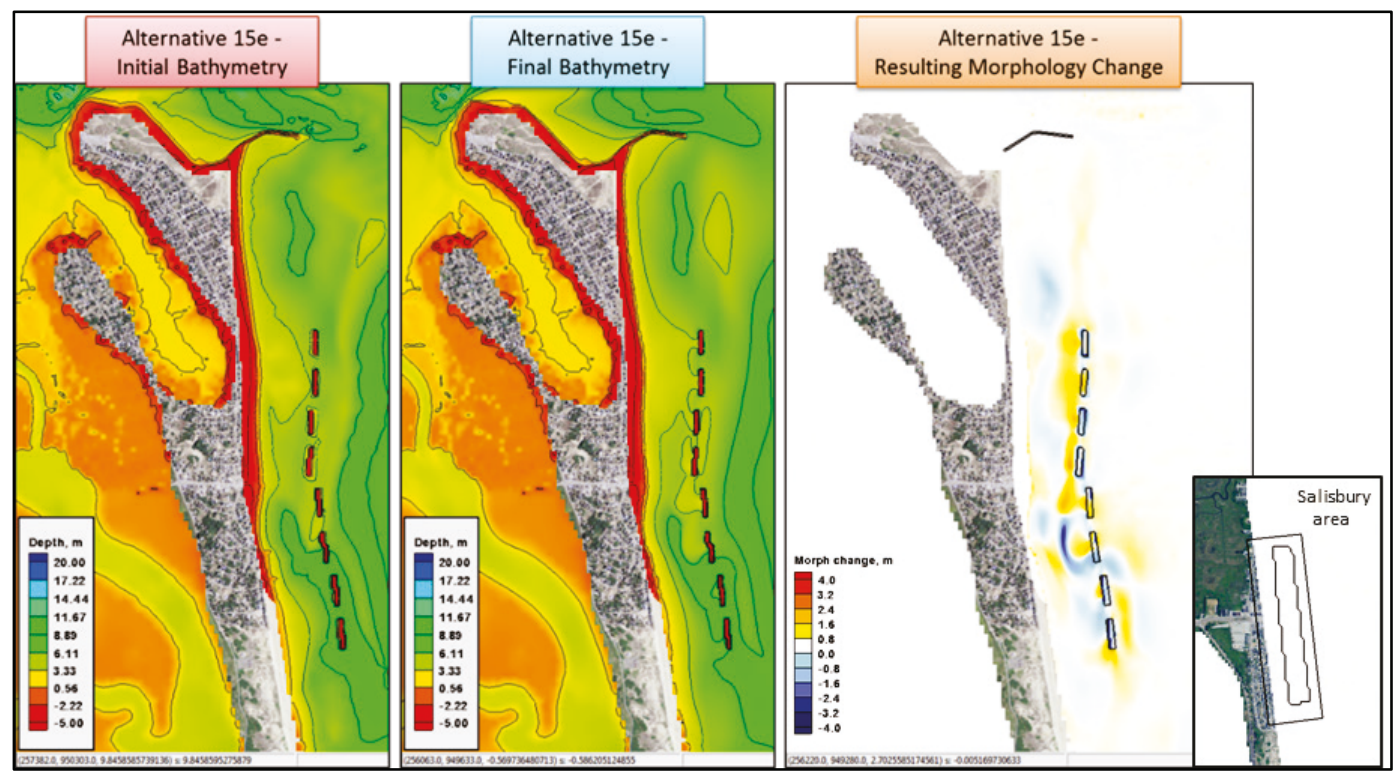


Figure 110. Difference in morphology change and bed volume changes within each beach area between Alternative $15 \mathrm{e}$ and base condition after 6-month simulation.

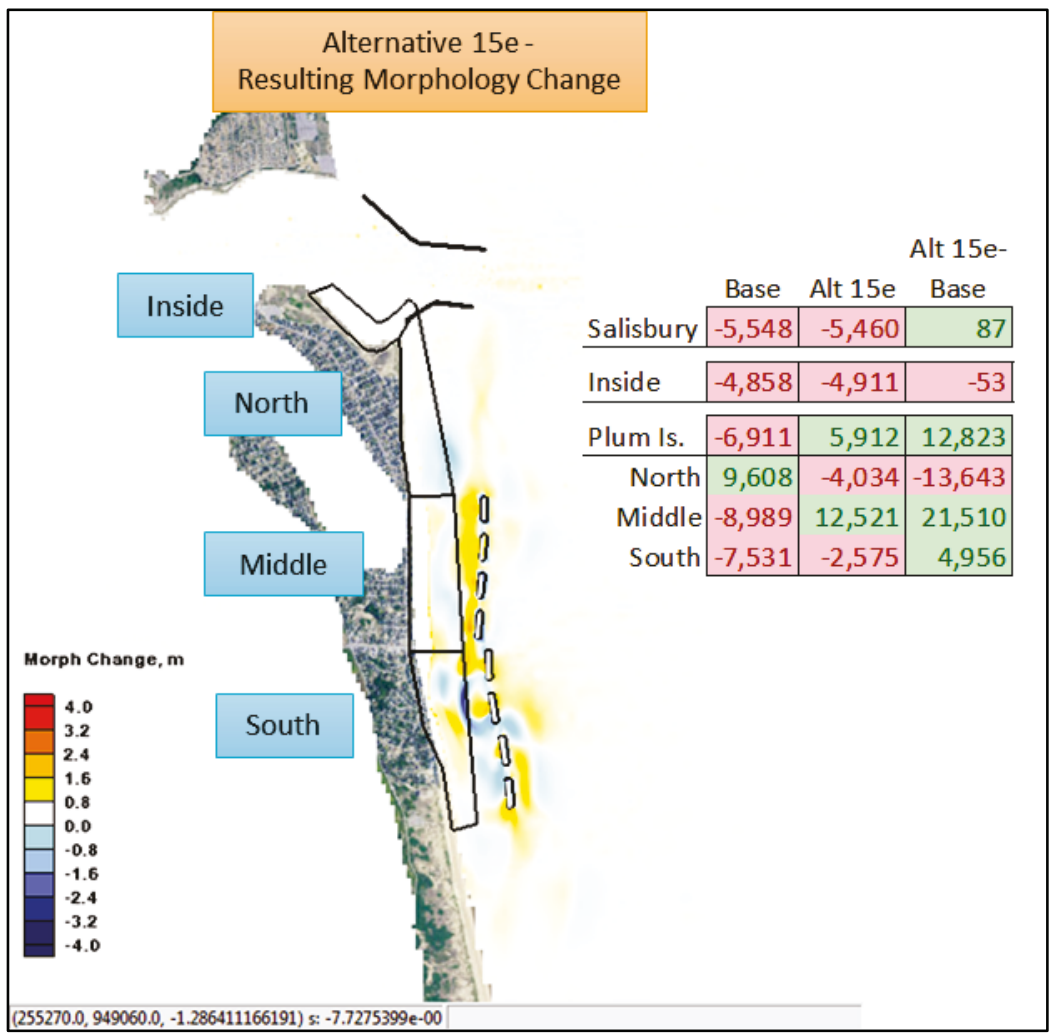

Ebb Delta and North Spit Mining, Alternative 16 (6 months)

The maximum mining and placement $\left(458,700 \mathrm{~m}^{3}[600,000 \mathrm{cu} y d]\right)$ were specified for this alternative. As shown in Figure 111, the mining areas correspond to accretion, and the placement areas correspond to erosion. Comparing with the base condition, approximately 47,399 more $\mathrm{m}^{3}$ $(62,000 \mathrm{cu} y d)$ of sediment (20.7\% of mined $229,350 \mathrm{~m}^{3}$ [300,000 cu yd] of sediment) filled in the mined area near the ebb shoal, and approximately 74,845 more $\mathrm{m}^{3}$ (97,900 cu yd) of sediment (32.6\% of mined 229,350 $\mathrm{m}^{3}$ [300,000 cu yd] of sediment) filled in the mined area at the North Spit. An amount of 3,670 more $\mathrm{m}^{3}$ (4,800 cu yd) of sediment material (4.8\% of original placed $76,450 \mathrm{~m}^{3}[100,000 \mathrm{cu} \mathrm{yd}]$ of sand) eroded and moved shoreward from the Salisbury placement zone. For this alternative, a significant amount of sediment eroded in the inside area (approximately 9,250 more $\mathrm{m}^{3}[12,100 \mathrm{cu}$ yd] compared with the base condition). The 229,350 $\mathrm{m}^{3}$ (300,000 cu yd) mining and 19,113 $\mathrm{m}^{3}$ $(25,000 \mathrm{cu} y d)$ placement nearby result in large sediment movement around the area (Figure 112). In the Middle and South areas and east of 
Plum Island, 9,862, 9,939, and 16,513 more $\mathrm{m}^{3}$ (12,900, 13,000, and $21,600 \mathrm{cu}$ yd) deposited related to $76,450 \mathrm{~m}^{3}$ (100,000 cu yd) and $286,688 \mathrm{~m}^{3}$ (375,000 $\left.\mathrm{cu} \mathrm{yd}\right)$ of sediment placement along the shoreline.

Figure 111. Initial bathymetry and final bathymetry of Alternative 16 and difference in morphology change between Alternative 16 and base condition.

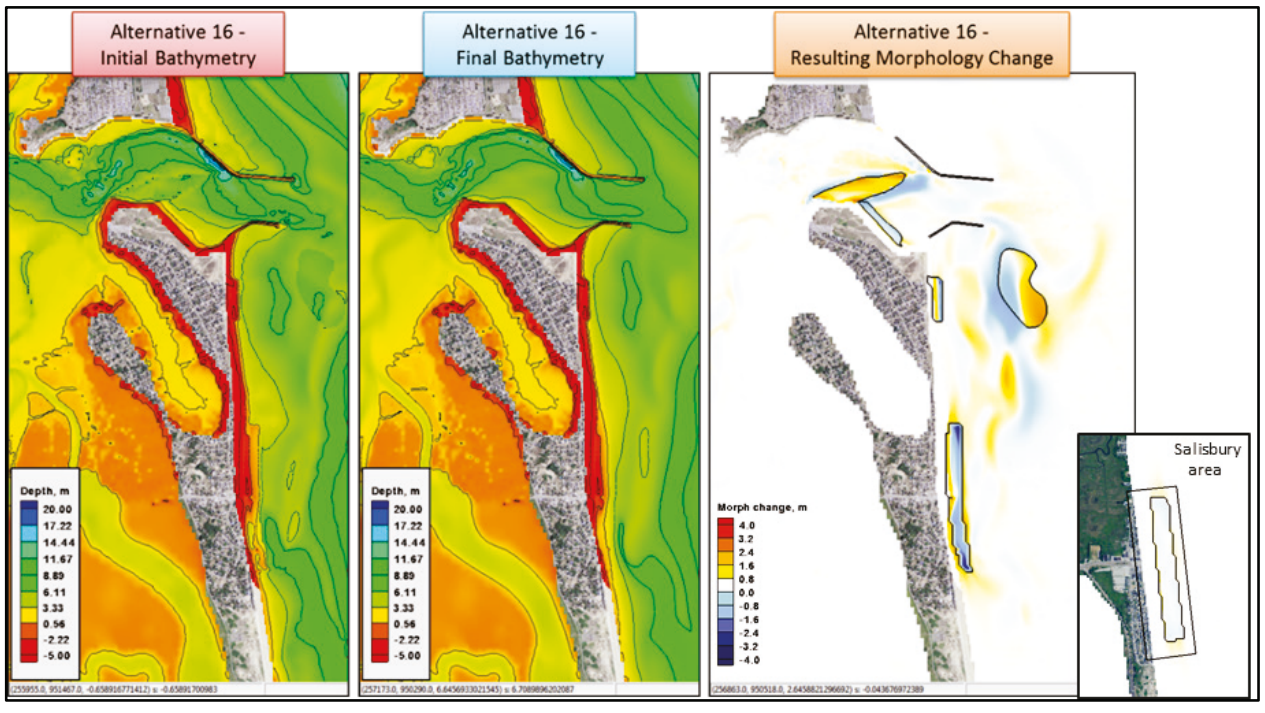

Figure 112. Difference in morphology change and bed volume changes within each beach area between Alternative 16 and base condition after 6-month simulation.

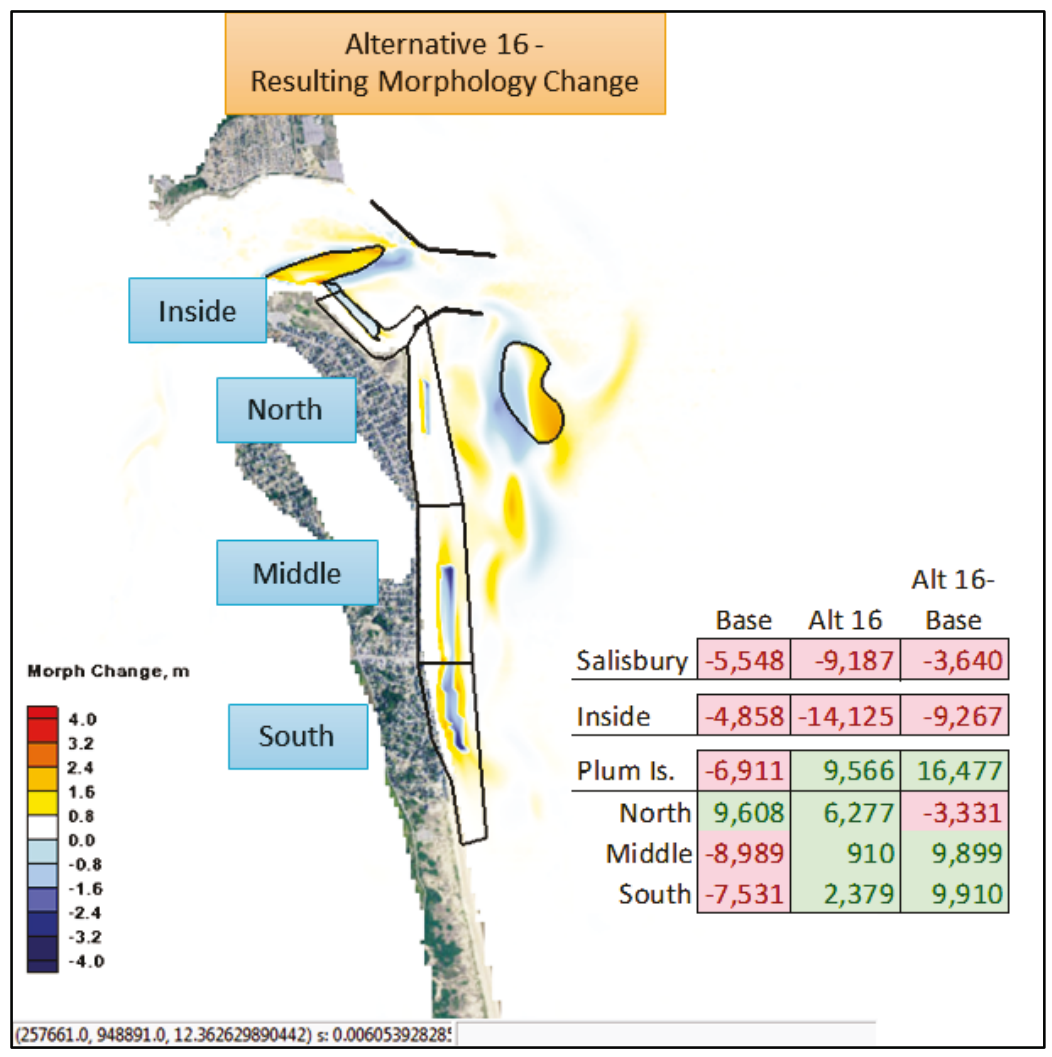


Ebb Delta Mining and Modified Placement Area, Alternative 17 (6 months)

This alternative attempts to bridge a bathymetry gap by mining sand near the ebb tidal delta. The results indicate significant flow change and sand movement around the mining and placement areas (Figure 113). Comparing with the base case, approximately 47,552 more $\mathrm{m}^{3}(62,200 \mathrm{cu}$ yd) of sediment (20.7\% of mined $229,350 \mathrm{~m}^{3}$ [300,000 cu yd] of sediment) filled in the mined area near the ebb shoal. The sand mining and placement change the flow pattern and result in 5,963 $\mathrm{m}^{3}(7,800 \mathrm{cu} \mathrm{yd})$ and $11,162 \mathrm{~m}^{3}$ $(14,600 \mathrm{cu} y d)$ of net sand accumulation in the North and Middle areas. At the placement area, 124,843 $\mathrm{m}^{3}(163,300 \mathrm{cu} y \mathrm{~d})$ of sand lost, $54.4 \%$ of placed 229,350 $\mathrm{m}^{3}$ (300,000 cu yd) of sediment, and most deposited near the site in shoreward direction (Figure 114).

Figure 113. Initial bathymetry and final bathymetry of Alternative 17 and difference in morphology change between Alternative 17 and base condition.

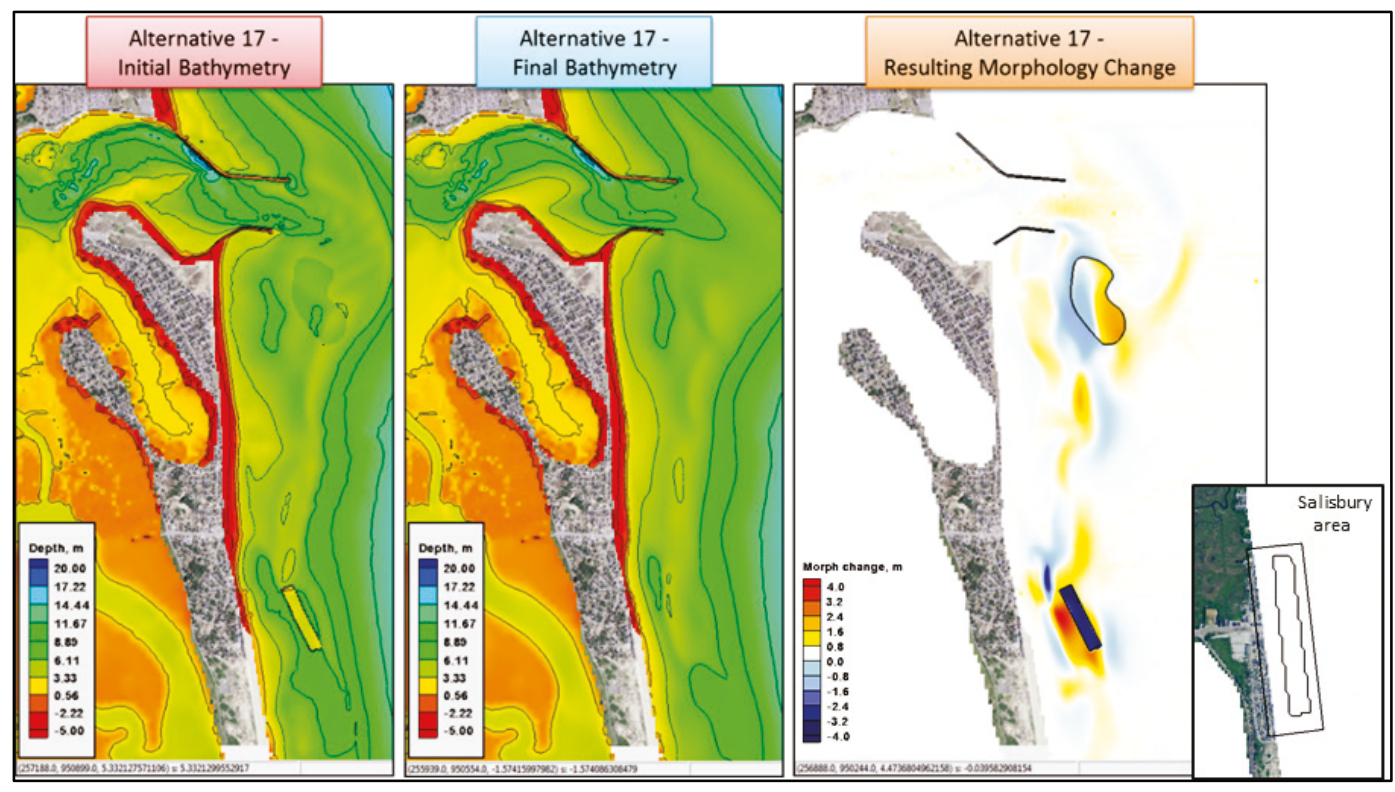


Figure 114. Difference in morphology change and bed volume changes within each beach area between Alternative 17 and base condition after 6-month simulation.

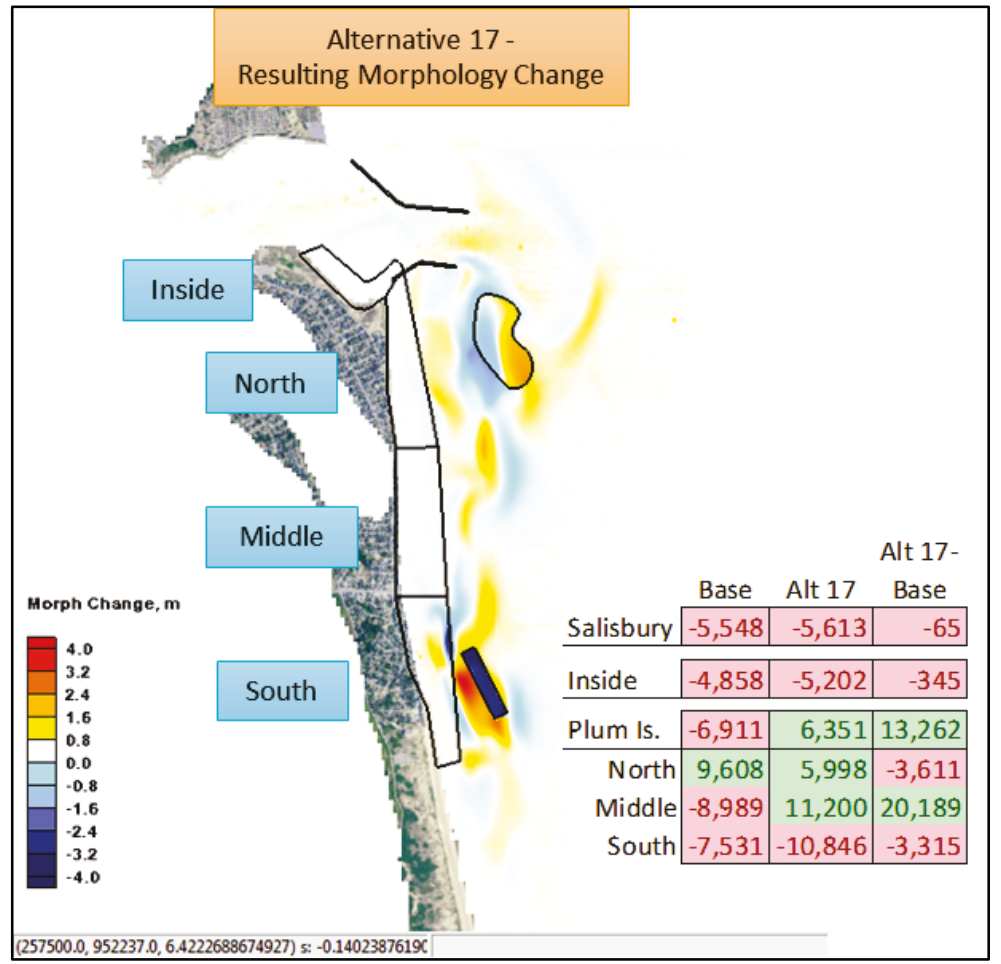

Table 3-6 and Table 3-7 summarize the bed volume changes of alternatives and the differences in bed volume changes between each alternative and the base case for five polygon areas, respectively. The pink color is designated for the erosive results, and the green color for the accretive results.

Table 3-6. Bed volume changes $\left(\times 1000 \mathrm{~m}^{3}\right)$ in five polygon areas under different alternatives.

\begin{tabular}{|l|l|c|c|c|c|c|c|c|c|}
\hline \multirow{2}{*}{ Area } & \multicolumn{9}{|c|}{ Alternative } \\
\cline { 2 - 11 } & $\mathbf{1}$ & $\mathbf{2}$ & $\mathbf{3 c}$ & $\mathbf{9}$ & $\mathbf{1 5 b}$ & $\mathbf{1 5 d}$ & $15 \mathrm{e}$ & $\mathbf{1 6}$ & $\mathbf{1 7}$ \\
\hline Salisbury & -9 & -9 & -9 & -5 & -5 & -9 & -5 & -9 & -6 \\
\hline Inside & -5 & -5 & -7 & -12 & -5 & -5 & -5 & -14 & -5 \\
\hline Plum Island & 10 & 14 & 15 & 41 & 9 & 6 & 6 & 10 & 6 \\
\hline North & 5 & 8 & 7 & 19 & 4 & -4 & -4 & 6 & 6 \\
\hline Middle & 0 & 1 & 0 & 14 & 3 & 13 & 13 & 1 & 11 \\
\hline South & 5 & 4 & 7 & 7 & 2 & -3 & -3 & 2 & -11 \\
\hline
\end{tabular}


Table 3-7. Difference in bed volume changes $\left(\times 1000 \mathrm{~m}^{3}\right)$ between alternative and base scenario in five polygon areas.

\begin{tabular}{|l|l|c|c|c|c|c|c|c|c|}
\hline \multirow{2}{*}{ Area } & \multicolumn{10}{|c|}{ Alternative } \\
\cline { 2 - 11 } & $\mathbf{1}$ & $\mathbf{2}$ & $\mathbf{3 c}$ & $\mathbf{9}$ & $\mathbf{1 5 b}$ & $\mathbf{1 5 d}$ & $\mathbf{1 5 e}$ & $\mathbf{1 6}$ & $\mathbf{1 7}$ \\
\hline Salisbury & -3 & -4 & -4 & 0 & 0 & -4 & 0 & -4 & 0 \\
\hline Inside & -1 & 0 & -2 & -8 & 0 & -1 & 0 & -9 & 0 \\
\hline Plum Island & 16 & 21 & 22 & 47 & -1 & 16 & 13 & 16 & 13 \\
\hline North & -5 & -1 & -2 & 10 & -3 & -6 & -14 & -3 & -4 \\
\hline Middle & 9 & 10 & 9 & 23 & -12 & 12 & 22 & 10 & 20 \\
\hline South & 12 & 12 & 15 & 15 & 15 & 10 & 5 & 10 & -3 \\
\hline
\end{tabular}

Under the base and all-alternative conditions, bed volume changes indicate that the Salisbury Beach area and Inside area north of Plum Island are erosive areas. The Salisbury area shows more erosion as mined sediment material is placed there and the created sand mound is dissipated (Alternatives 1, 2, 3c, 15d, and 16). In the Inside area, more sediment erosion is primarily related to flow regime change due to shortening jetties (Alternative 9) and mining/placement adjacent to the area (Alternatives $3 \mathrm{c}$ and 16 ).

The North, Middle, and South areas are located downdrift of Merrimack Inlet. The bed volume changes in those areas are directly affected by longshore sediment transport and structure modifications, which is demonstrated by the most sediment accretion as the jetties are cut short (Alternative 9). Although net sediment accretion occurs under the alternatives of sediment placement, jetty shortening, and breakwater protection in the north area, less sediment material moves to the area comparing with the results under the base condition. Without the protection of the detached breakwaters (Alternative 15e), most sediment is lost in the area. Associated with sediment placement, jetty shortening, and detached breakwater protection, and comparing with the base case, significant sediment accretion occurs under most of the alternatives in the Middle and South areas. The only two exceptions are Alternative 15b in the Middle area and Alternative 17 in the South area. Narrowing the flow pathway by building detached breakwaters and bridging the bathymetric gap could induce stronger current and more sediment erosion. 


\section{Summary}

The NAE and the ERDC-CHL, performed a numerical modeling study to address the concerns on beach erosion adjacent to, and the navigability of, Merrimack Inlet, Newburyport, MA. The study consisted of two phases. Twenty-four alternatives were specified, and model simulations were conducted with different jetty configurations, additional structures, and mining and placement scenarios. Each alternative in the Phase I study was compared with the 2011 pre-rehabilitation condition. Phase II compared alternatives with the 2014 fully rehabilitated South Jetty condition. The results of Phase I and Phase II numerical modeling alternatives were evaluated in terms of its ability to reduce erosion of the adjacent beaches, maintain high performance of the jetties, and decrease shoaling in the inlet. Ultimately, the numerical modeling results can be synthesized to offer valuable insight and predictive capability required to develop a comprehensive sediment management strategy for Merrimack Inlet and the adjacent beaches.

Hydrodynamics and sediment transport were simulated by the CMS, an integrated wave, flow, and sediment transport modeling system. The model performance was investigated by comparing to measurements of WSE and current at four tide gauges and two ADCP gauges in Plum Island Sound and at the Merrimack Inlet, respectively. The calculated morphology change was validated by hydrodynamic measurements, channel condition surveys, and the latest lidar surveys of the inlet system. Comparisons of the CMS results and measured data indicate that tide is the dominating forcing around the inlet and in the estuarine system. The depth average current has a maximum speed of greater than $1.3 \mathrm{~m} / \mathrm{s}$ $(4.3 \mathrm{ft} / \mathrm{s})$ at the inlet channel. The average current and sediment transport indicate that the net flow and sediment flux are towards the open ocean through the inlet due to excessive freshwater inflows into the Sound. The pattern in morphology changes corresponds well to measured erosion and accretion pattern around the navigation channel, ebb tidal delta, Salisbury Beach, and Plum Island. The winter storm and wave conditions contribute to stronger alongshore currents and larger sediment transport and inlet morphology change. Overall, the morphologic features of interest for sediment management, borrow areas and placement areas, were well reproduced and examined with the CMS. 
The alternatives designed for the Phase I study include the sand management, the structure modification, and the combination of two. The qualitative result analysis indicates that (1) the mining zones near the ebb tidal delta and at the north spit tend to trap sand material, the mining near the flood tidal shoal does not result in significant morphology change and sand trapping, and the sedimentation basin within the South Jetty is not efficient to trap sand material; (2) the sand material placed in front of Salisbury Beach and Plum Island Beach shows net erosion after 1-month or 6-month simulations. The Salisbury Beach placement zone shows minor sand movement and the Plum Island zone shows more significant sand movement; (3) completely or partially removing jetties results in significant channel infilling; (4) jetty extension and reorientation, adding a spur inside the North Jetty, or adding doglegs to jetties strengthen alongchannel current, trigger sediment movement around the inlet channel, and push the ebb tidal delta farther offshore; and (5) the detached breakwaters south of the South Jetty increase shoreward sand migration and protect the Plum Island shoreline from wave impact.

In the Phase II study, the alternatives were selected and designed focusing on the north of Plum Island within the South Jetty, Plum Island Beach, and Salisbury Beach. The analysis on bed volume changes in the five polygon areas indicates that (1) sediment material placed in Salisbury Beach tends to be carried away by longshore current; (2) the mining zones near the ebb tidal delta and at the north spit tend to trap sand material and trigger sand movement around. The mining near the flood tidal shoal does not result in significant morphology change and sand trapping but induces more erosion north of Plum Island; (3) adjusting the mining location near the ebb tidal delta shoreward does not change sediment erosion/accretion patterns in the study area; (4) shortening jetties results in significant channel infilling and sediment bypassing around the inlet channel and causes more erosion north of Plum Island and more accretion east of Plum Island; (5) the sand material placed in front of Plum Island Beach is eroded at a small rate; the sand movement is in the seaward, shoreward, and longshore directions; (6) the detached breakwaters south of the South Jetty decrease wave energy and protect the Plum Island shoreline but could enhance the longshore current between shoreline and breakwaters; and (7) bridging a bathymetry gap south of Plum Island Beach corresponds to significant erosion in the placement box and accretion in the shoreward direction. 
Summing up the results of the sediment transport and bed volume analysis on sand management and structure alternatives, it can be seen that a mined area around the ebb tidal delta may act to trap a large quantity of sediment material and the placement of sand material in front of Plum Island beaches may favor the shoreward sand movement. Detached nearshore breakwaters would damp wave energy and protect shoreline from erosion.

As mentioned in the previous section, the CMS has limitation in simulating beach process and shoreline growth and retreat. To properly address issues related to beach process and morphological evolution near land-water interface, a shoreline change model is needed. CIRP has developed and is maintaining such a model, GENCADE (Frey et al. 2012; Beck and Legault 2012), which may be coupled with the CMS for future sediment transport and shoreline evolution studies in the coastal zone. Six-month simulations were performed in this study. To include annual channel O\&M practice and evaluate long-term morphodynamic processes, future numerical studies should be set up for multi-year simulations. 


\section{References}

Abele, R. W. 1977. Analysis of Short-Term Variations in Beach Morphology (and Concurrent Dynamic Processes) for Summer and WINTER Periods, 1971-72. USACOE, Plum Island, Massachusetts, Fort Belvoir, VA.

Beck, T. B., and N. C. Kraus. 2010. Shark River Inlet, New Jersey, Entrance Shoaling: Report 2, Analysis with Coastal Modeling System. ERDC/CHL-TR-10-4. Vicksburg, MS: U.S. Army Engineer Research and Development Center.

Beck, T. B., and K. Legault. 2012. Optimization of Ebb Shoal Mining and Beach Nourishment at St. Johns County, St. Augustine Inlet, Florida: Report 3. ERDC/CHL-TR-12-14. Vicksburg, MS: U.S. Army Engineer Research and Development Center.

Buttolph, A. M., C. W. Reed, N. C. Kraus, N. Ono, M. Larson, B. Camenen, H. Hanson, T. Wamsley, and A. K. Zundel. 2006. Two-Dimensional Depth-Averaged Circulation Model CMS-M2D: Version 3.o, Report 2: Sediment Transport and Morphology Change. ERDC/CHL TR-06-09. Vicksburg, MS: U.S. Army Engineer Research and Development Center.

Chiaramida, A. 2008. "A Beloved Resort Erodes Gradually, Salisbury Beach Washes Away." The Salem News, 31 March 2008. http://www.salemnews.com/local/x845839693/A-beloved-resort-erodes-Gradually-SalisburyBeach-washes-away. Accessed 22 January 2013.

Costas, S., and D. FitzGerald. 2011. "Sedimentary Architecture of a Spit-End (Salisbury Beach, Massachusetts): The Imprints of Sea-Level Rise and Inlet Dynamics." Marine Geology 284: 203-216.

Demirbilek, Z., L. Lin, J. Smith, E. Hayter, E. Smith, J. Z. Gailani, G. J. Norwood, and D. R. Michalsen. 2010. Waves, Hydrodynamics and Sediment Transport Modeling at Grays Harbor, WA. ERDC/CHL TR-10-13. Vicksburg, MS: U.S. Army Engineer Research and Development Center.

Demirbilek, Z., and J. Rosati. 2011. Verification and Validation of the Coastal Modeling System, Report 1: Summary Report. ERDC/CHL TR-11-10. Vicksburg, MS: U.S. Army Engineer Research and Development Center.

FitzGerald, D. M. 1984. "Interactions between the Ebb-Tidal Delta and Landward Shoreline: Price Inlet, South Carolina.” Journal of Sedimentary Petrology 54(4): 1303-1318.

FitzGerald, D. M. 1993. "Origin and Stability of Tidal Inlets in Massachusetts.” In Formation and Evolution of Multiple Tidal Inlets. Coastal and Estuarine Studies. Edited by D. G. Aubrey and G. S. Giese, 1-61. Washington, DC: American Geophysical Union.

FitzGerald, D. M., I. V. Buynevich, R. A. Davis, M. S. Fenster. 2002. "New England Tidal Inlets with Special Reference to Riverine-Associated Inlet Systems." Geomorphology 48: 179-208. 
FitzGerald, D. M., and S. Van Heteren. 1999. "Classification of Paraglacial Barrier Systems: Coastal New England, USA.” Sedimentology 46(6): 1083-1108.

Frey, A., K. Connell, H. Hanson, M. Larson, R. Thomas, S. Munger, and A. Zundel. 2012. GenCade Version 1 Model Theory and User's Guide. ERDC/CHL TR-12-25. Vicksburg, MS: U.S. Army Engineer Research and Development Center.

Hartwell, A. D. 1970. Hydrography and Holocene Sedimentation of the Merrimack River estuary, Massachusetts, 166. Technical Report CRG-5. Department of Geology, University of Massachusetts.

Hayes, M. O. 1979. "Barrier Island Morphology as a Function of Tidal and Wave Regime." In Barrier Islands: From the Gulf of St. Lawrence to the Gulf of Mexico. Edited by S. P. Leatherman, 1-28. New York: Academic Press.

Hein, C. J., D. M. FitzGerald, E. A. Carruthers, B. D. Stone, W. A. Barnhardt, and A. M. Gontz. 2012. "Refining the Model of Barrier Island Formation along a Paraglacial Coast in the Gulf of Maine." Marine Geology, Vols. 307-310, 15 April 2012: 4057.

Hubbard, D. K. 1975. "Morphology and Hydrodynamics of the Merrimack River EbbTidal Delta.” In Estuarine Research. Edited by L. E. Cronin, 253-266. New York: Academic Press.

Lambert, S. S., S. S. Willey, T. Campbell, R. C. Thomas, H. Li, L. Lin, and T. L. Welp. 2013. Regional Sediment Management studies of Matagorda Ship Channel and Matagorda Bay System, Texas. ERDC/CHL TR-13-10. Vicksburg, MS: U.S. Army Engineer Research and Development Center.

Li, H., M. E. Brown, T. D. Smith, and J. H. Podoski. 2009. Evaluation of Proposed Channel on Circulation and Morphology Change at Kawaihae Harbor and Pelekane Bay, Island of Hawaii, HI. ERDC/CHL-TR-09-19. Vicksburg, MS: U.S. Army Engineer Research and Development Center.

Lin, L., Z. Demirbilek, H. Mase, and J. Zheng. 2008. CMS-Wave: A Nearshore Spectral Wave Processes Model for Coastal Inlets and Navigation Projects. ERDC/CHL TR-08-13. Vicksburg, MS: U.S. Army Engineer Research and Development Center.

Lin, L., Z. Demirbilek, R. Thomas, and J. Rosati, III. 2011. Verification and Validation of the Coastal Modeling System, Report 2: CMS-Wave. ERDC/CHL TR-11-10. Vicksburg, MS: U.S. Army Engineer Research and Development Center.

Lin, L., H. Li, M. E. Brown, F. Wu, and L. Andes. 2013. Pilot Study Evaluating Nearshore Sediment Placement Sites, Noyo Harbor, CA. ERDC/CHL TR-13-2. Vicksburg, MS: U.S. Army Engineer Research and Development Center.

Lu, C. C., A. Shak, H. Li, and L. Lin. 2014. Comprehensive Condition Survey and Storm Waves, Circulation, and Sedimentation Study, Dana Point Harbor, California. ERDC/CHL TR-14-13. Vicksburg, MS: U.S. Army Engineer Research and Development Center. 
Mase, H., K. Oki, T. S. Hedges, and H. J. Li. 2005. "Extended Energy-Balance-Equation Wave Model for Multidirectional Random Wave Transformation." Ocean Engineering 32(8-9): 961-985.

National Geophysical Data Center (NGDC). 2009. Bathymetry, Topography, and Relief. http://www.ngdc.noaa.gov/mgg/bathymetry/relief.html.

Reed, C. W., and L. Lin. 2011. "Analysis of Packery Channel Public Access Boat Ramp Shoreline Failure.” Journal of Coastal Research Special Edition, Coastal Education and Research Foundation, Inc., Special Issue 59: 150-155.

Sanchez, A., W. Wu, T. M. Beck, H. Li, J. Rosati III, R. Thomas, J. D. Rosati, Z. Demirbilek, M. Brown, and C. Reed. 2011a. Verification and validation of the Coastal Modeling System, Report 3, CMS-Flow: Hydrodynamics. ERDC/CHL TR-11-10. Vicksburg, MS: U.S. Army Engineer Research and Development Center.

Sanchez, A., W. Wu, T. M. Beck, H. Li, J. D. Rosati, Z. Demirbilek, and M. Brown. 2011b. Verification and Validation of the Coastal Modeling System, Report 4, CMSFlow: Sediment Transport and Morphology Change. ERDC/CHL TR-11-10. Vicksburg, MS: U.S. Army Engineer Research and Development Center.

Smith, J. B., and D. M. FitzGerald.1994. "Sediment Transport Patterns at the Essex River Inlet Ebb Tidal Delta, Massachusetts, U.S.A. Journal of Coastal Research 10: 752-774.

U.S. Army Corps of Engineers (USACE). 1917. Report of the Chief of Engineers, Vol. 2, 1928, 69-70.

USACE, New England District. 1965. Newburyport Harbor, Massachusetts, Design Memorandum on Rehabilitation - North and South Jetties. U.S. Army Corps of Engineers, New England District.

USACE, New England District. 2009. "Newburyport Harbor, Plum Island \& Salisbury Beaches." Section 204 Detailed Project Report and Environmental Assessment for Beneficial Use of Dredged Materials from Maintenance Dredging, September.

U.S. Geological Survey (USGS) 2016. U.S. Geological Survey East-Coast Sediment Texture Database. http://woodshole.er.usgs.gov/project-pages/sediment/gis-data-catalog.html.

Vallino, J. J., and C. S. Hopkinson, Jr. 1998. "Estimation of Dispersion and Characteristic Mixing Times in Plum Island Sound Estuary." Estuarine, Coastal and Shelf Science 46(3): 333-350.

Wang, P., K. E. Brutsche, J. W. LaGrone, T. M. Beck, J. D. Rosati, and L. S. Lillycrop. 2013. Performance Monitoring of a Nearshore Berm at Ft. Myers Beach, Florida. ERDC/CHL TR-13-11. Vicksburg, MS: U.S. Army Engineer Research and Development Center.

Wu, W., A. Sanchez, and M. Zheng. 2010. "An Implicit 2-D Depth-Averaged Finite Volume Model of Flow and Sediment Transport in Coastal Waters." In Proceedings of the International Conference on Coastal Engineering. http://journals.tdl.org/icce/index.php/icce/article/view/1431/pdf_380. 
Wu, W., A. Sanchez, and M. Zheng. 2011. "An Implicit 2-D Shallow Water Flow Model on Unstructured Quadtree Rectangular Mesh.” Journal of Coastal Research Special Issue 59: 15-26.

Zhao, L., C. Chen, J. Vallino, C. Hopkinson, R. C. Beardsley, H. Lin, and J. Lerczak. 2010. "Wetland-Estuarine-Shelf Interactions in the Plum Island Sound and Merrimack River in the Massachusetts Coast." Journal of Geophysical Research 115 (10):

C10039. http://dx.doi.org/10.1029/2009JC006085. 


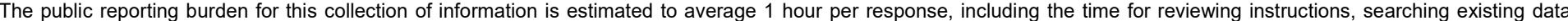

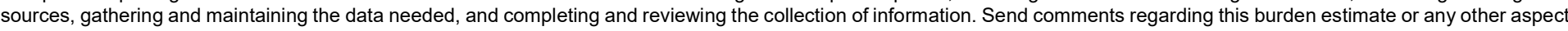

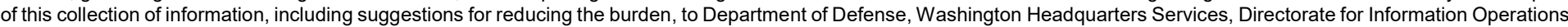

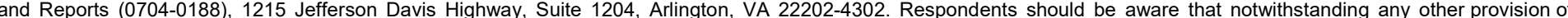
law, no person shall be subject to any penalty for failing to comply with a collection of information if it does not display a currently valid OMB control number.

PLEASE DO NOT RETURN YOUR FORM TO THE ABOVE ADDRESS.

\begin{tabular}{|l|l|l|l|}
\hline 1. REPORT DATE & 2. REPORT TYPE & 3. DATES COVERED (FrOm - To)
\end{tabular}

\begin{tabular}{|l|l}
\hline June 2018 & Final Report
\end{tabular}

\section{TITLE AND SUBTITLE}

Merrimack Estuary and Newburyport Harbor Sediment Management Studies
3. DATES COVERED (From - To)

5a. CONTRACT NUMBER

5b. GRANT NUMBER

5c. PROGRAM ELEMENT NUMBER

5d. PROJECT NUMBER

152124

5e. TASK NUMBER

5f. WORK UNIT NUMBER

8. PERFORMING ORGANIZATION REPORT NUMBER

ERDC/CHL TR-18-7

10. SPONSOR/MONITOR'S ACRONYM(S)

USACE NAE

11. SPONSOR/MONITOR'S REPORT NUMBER(S)
U.S. Army Corps of Engineers, New England District

696 Virginia Road

Concord, MA 01742

\section{DISTRIBUTION/AVAILABILITY STATEMENT}

Approved for public release; distribution is unlimited.

\section{SUPPLEMENTARY NOTES}

\section{ABSTRACT}

This report documents a numerical modeling study investigating sediment transport and morphology change adjacent to Merrimack Inlet, Newburyport, and nearshore in the vicinity of Salisbury Beach and Plum Island, Massachusetts. Concerns at the site include beach erosion, shoreline retreat on Plum Island downdrift of and within the inlet, and reduced navigability of the inlet. The numerical modeling evaluation consists of two phases. The Phase I study was conducted with the damaged and partially rehabilitated South Jetty between 2012 and 2014, and the Phase II study was conducted with the fully rehabilitated South Jetty between 2015 and 2016.

Historical hydrodynamic and sediment data in the study area were assembled, and a field data collection program was carried out. The datasets were used to develop a coastal wave, hydrodynamic, and sediment transport model. Different alternatives were developed to evaluate sediment management strategy and structure modification, and the calculated bed sediment volume changes of each alternative were compared with the results under base (existing) condition. Alternative simulations demonstrated the Coastal Modeling System capability in evaluating beach erosion, structure performance, sediment transport, and morphology change in the inlet and estuarine system.

\section{SUBJECT TERMS}

Estuaries, Harbors-Newburyport (Mass.), Inlets, Sedimentation and deposition, Sediment transport

\section{SECURITY CLASSIFICATION OF:}

\begin{tabular}{|l|l|l|l|}
\hline a. REPORT & b. ABSTRACT & c. THIS PAGE & ABSTRACT \\
Unclassified & Unclassified & Unclassified & SAR \\
\end{tabular}

18. NUMBER OF PAGES

127 19a. NAME OF RESPONSIBLE PERSON

Honghai Li

19b. TELEPHONE NUMBER (Include area code) 601-634-2840 
7. PERFORMING ORGANIZATION NAME(S) AND ADDRESS(ES)

(continued)

Coastal and Hydraulics Laboratory

U.S. Army Engineer Research and Development Center 3909 Halls Ferry Road

Vicksburg, MS 39180-6199

New England District

U.S. Army Corps of Engineers

696 Virginia Road

Concord, MA 01742

Florida Institute of Technology

150 West University Boulevard

Melbourne, FL 32901 